\title{
Site U1391
}

\author{
Expedition 339 Scientists $^{2}$
}

\section{Chapter contents}

Background and objectives.......... 1

Operations................... 2

Lithostratigraphy.............. 3

Biostratigraphy ............... 6

Paleomagnetism .................. 9

Physical properties .............. 10

Geochemistry ................ 13

Downhole measurements........... 15

Stratigraphic correlation. . . . . . . . . 16

References................... 17

Figures................... 20

Tables..................... 81

1'Expedition 339 Scientists, 2013. Site U1391. In Stow, D.A.V., Hernández-Molina, F.J., Alvarez Zarikian, C.A., and the Expedition 339 Scientists, Proc. IODP, 339: Tokyo (Integrated Ocean Drilling Program Management International, Inc.). doi:10.2204/iodp.proc.339.109.2013

2Expedition 339 Scientists' addresses.

\section{Background and objectives}

Integrated Ocean Drilling Program (IODP) Site U1391 is located on the West Iberian margin $\left(37^{\circ} 21.5322^{\prime} \mathrm{N}, 9^{\circ} 24.6558^{\prime} \mathrm{W}\right)$ and represents the most distal site within the contourite depositional system (CDS) explored during Expedition 339 (Fig. F1, F2). It is situated over a large plastered drift on the middle slope terrace from Sector 5 of the CDS (the canyons sector in Stow et al., 2011, previously defined by Hernández-Molina et al., 2003, and Llave et al., 2007). This site represents an opportunity for recovering a sedimentary record for the Quaternary and Pliocene caused by Mediterranean Outflow Water (MOW) deposition on the southwest Portuguese margin (see Fig. F21 in the "Expedition 339 summary" chapter [Expedition 339 Scientists, 2013a]).

Regional work has determined the tectonic and stratigraphic evolution of this part of the margin. These previous studies identified that the sedimentary record of the southwest Portuguese margin spans from the Late Triassic through Quaternary and consists of Mesozoic rift and postrift sediments deformed during the Cenozoic alpine compression (Terrinha et al., 2003). Major unconformities/hiatuses generated during this tectonic inversion phase separate Late Cretaceous from middle Eocene sediments and late Eocene from early Miocene sediments (Alves et al., 2003; Pereira et al., 2011). The present-day morphostructural attributes of the margin are the result of the middle Miocene uplift of fault blocks inherited from the Mesozoic rifting phases. This structural compartmentalization of the margin controlled its tectonic and sedimentary evolution during the Pliocene and Quaternary transpressive regime because of the activity of some structures located near Site U1391, such as the São Vicente Canyon and Horseshoe faults to the south, the Pereira de Sousa fault to the north, and the Marquês de Pombal fault to the east (e.g., Alves et al., 2000; Terrinha et al., 2003; Zitellini et al., 2004).

In this morphostructural context, contourite features developed over the middle slope as a northward extension of the CDS from the Gulf of Cádiz. As no previous work has been published on contourite sedimentation along this margin, the results from this site are very important for increasing the knowledge of margin evolution. The plastered drift at this site is one of a series of contourite features formed under the influence of the northern branch of MOW as it continues north along the Iberian margin and beyond (Iorga and Lozier, 1999; Serra et al., 2010). These in- 
clude those along the middle slope of the northwest Portuguese margin (Alves et al., 2003; Pereira and Alves, 2011), the Galicia Bank and Galician slope (Ercilla et al. 2009, 2010, 2011; Bender et al. 2010; Mena et al. 2010), Ortegal Spur (Hernández-Molina et al. 2009), Le Danois Bank or "Cachucho" (Ercilla et al. 2008; Iglesias, 2009; Van Rooij et al. 2010), and the Porcupine slope (Van Rooij et al., 2003).

\section{Objectives}

The major objective for Site U1391 was to recover a sedimentary contourite record for the Pliocene and Quaternary deposited under the influence of MOW along the West Iberian margin (see Fig. F21 in the "Expedition 339 summary" chapter [Expedition 339 Scientists, 2013a]). This record will allow us to investigate more specific objectives including

- The influence of the Strait of Gibraltar (or Gibraltar Gateway) through the Pliocene and the Quaternary in the West Iberian margin,

- MOW paleoceanography and its global climate significance during the last 4 m.y.,

- The effects of climate and sea level changes on the sediment architecture of the plastered drift on the middle slope off Portugal, and

- The sedimentary stacking pattern of the plastered drift in relation to changes in sea level and other forcing mechanisms.

To achieve these major scientific objectives, it is essential to integrate the results from Site U1391 with a network of existing seismic reflection profiles from the Portuguese margin and to correlate these with results from the Gulf of Cádiz.

\section{Operations}

The $115 \mathrm{nmi}$ voyage from Site U1390 to Site U1391 (proposed Site WI-01B) was made at an average speed of $11.5 \mathrm{kt}$. The vessel was positioned on the last site of the expedition at $1230 \mathrm{~h}$ on 8 January 2012.

Three holes were drilled at Site U1391 (Table T1). Hole U1391A was cored using the advanced piston corer (APC) to 171.1 meters below seafloor (mbsf) and then with the extended core barrel (XCB) to 353.1 mbsf. Hole U1391B was cored using the APC to $171 \mathrm{mbsf}$ and then with the XCB to $353.5 \mathrm{mbsf}$. Hole U1391C was drilled without recovery to 340 mbsf and then cored using the rotary core barrel (RCB) to 671.5 mbsf. Downhole logging was carried out in Hole U1391C using the triple combination (triple combo) and Formation MicroScanner (FMS)sonic tool strings (see "Downhole logging at Site U1391"). Overall recovery at Site U1391 was 342.1 $\mathrm{m}$ (104.7\% recovery) with the APC, $230.7 \mathrm{~m}(90.7 \%$ recovery) with the $\mathrm{XCB}$, and $269.02 \mathrm{~m}(81.15 \%$ recovery) with the RCB. The total cored interval at Site $\mathrm{U} 1391$ was $1038.1 \mathrm{~m}$ and total recovery was 958.57 m $(92.3 \%)$.

\section{Hole U1391A}

The APC/XCB bottom-hole assembly (BHA) was made up, and a routine survey of the seafloor was conducted using a $30 \mathrm{~m}$ grid pattern. No significant obstructions were observed. Hole U1391A was spudded with the APC at 1080.0 meters below sea floor (mbrf; 1078.3 meters below sea level [mbsl]) at 2035 h on 8 January. Seafloor depth was established at 1085.4 mbrf (1073.7 mbsl). Piston coring advanced to a final depth of $171.1 \mathrm{mbsf}$, with a recovery of $106 \%$. Cores were oriented starting with Core $4 \mathrm{H}$. Temperature measurements were made at 32.6 (Core $4 \mathrm{H}), 61.1($ Core $7 \mathrm{H}), 89.6$ (Core $10 \mathrm{H}), 118.1$ (Core $13 \mathrm{H})$, and 146.6 (Core $16 \mathrm{H})$ mbsf. Nonmagnetic core barrels were used to obtain all piston cores. XCB coring deepened the hole to the depth objective of $353.1 \mathrm{mbsf}$ by $0345 \mathrm{~h}$ on 10 January. Average recovery for the $182 \mathrm{~m} \mathrm{XCB}$ interval was $88.8 \%$. Combined recovery in Hole U1391A was 97\%. The drill string was pulled out of the hole, clearing the seafloor at $0520 \mathrm{~h}$ on 10 January. The vessel was offset $20 \mathrm{~m}$ south of Hole U1391A.

\section{Hole U1391B}

Hole U1391B was spudded with the APC at 1085 mbrf at $0815 \mathrm{~h}$ on 10 January. Although the mudline core was $9.65 \mathrm{~m}$, the desired vertical offset $(5 \mathrm{~m}$ deeper) with the previous hole was maintained and piston coring continued to a final depth of $171 \mathrm{mbsf}$ with a recovery of $104 \%$. Cores were oriented starting with Core $3 \mathrm{H}$. Temperature measurements were made at $19($ Core $2 \mathrm{H}), 47.5($ Core $5 \mathrm{H}), 76($ Core $8 \mathrm{H})$, 104.5 (Core 11H), and 133 (Core 14H) mbsf. All cores were obtained with nonmagnetic core barrels. $\mathrm{XCB}$ coring deepened the hole to the depth objective of 353.5 mbsf. Average recovery for the XCB interval of $182.5 \mathrm{~m}$ was $93 \%$. Combined recovery for Hole U1391B was 98\%. The drill string was recovered with the bit clearing the seafloor at $1350 \mathrm{~h}$ and the rotary table at $1850 \mathrm{~h}$ on 11 January. The trip out of the hole was suspended $1.5 \mathrm{~h}$ for the routine maintenance procedure of slipping and cutting the drilling line.

\section{Hole U1391C}

A four-stand RCB BHA was made up with a new CC4 Rock Bit International bit and mechanical bit release and deployed. After the driller tagged the sea- 
floor at 1085 mbrf (1073.3 mbsl), Hole U1391C was spudded with the RCB at $2345 \mathrm{~h}$ on 11 January. The hole was drilled with a wash barrel to 340 mbsf by $1400 \mathrm{~h}$ on 12 January. The empty wash barrel was recovered and a fresh core barrel dropped at $1430 \mathrm{~h}$, when rotary coring was initiated. Rotary coring advanced to a final depth of $671.5 \mathrm{mbsf}$ by $1645 \mathrm{~h}$ on 14 January. Recovery for the $331.5 \mathrm{~m}$ cored interval in Hole U1391C was $81 \%$. Recovery percentage was adversely affected by the absence of recovery in Cores 26R, 29R, and 35R, which was assumed to be formation related. The average rate of penetration for the $331.5 \mathrm{~m}$ cored interval was $14.2 \mathrm{~m} / \mathrm{h}$.

\section{Downhole logging at Site U1391}

Following the wiper trip, Hole U1391C was flushed with sepiolite mud and the bit was released at the bottom. The hole was displaced with $248 \mathrm{bbl}$ of 10.5 ppg heavy mud, and the end of pipe was placed at the logging depth of 98.9 mbsf. The first log of the hole was made with the triple combo tool string, which was made up of the natural gamma radiation (NGR), density, and resistivity tools and deployed at $0330 \mathrm{~h}$ on 15 January. The tool string succeeded in reaching 668 mbsf. The tool string was recovered and rigged down by $0815 \mathrm{~h}$. The second and final log was made with the FMS-sonic tool string. The tool string reached $666 \mathrm{mbsf}$ and recorded resistivity images of the borehole, sonic velocities, and NGR data. The hole contained many thin washouts. As at previous sites, all the logs have medium-amplitude alternations on the several-meter scale. Sonic velocity, density, and resistivity all show a downhole compaction trend. Logging equipment was rigged down by $1915 \mathrm{~h}$, concluding all science operations of the expedition. We departed Site U1391 at $0200 \mathrm{~h}$ on 16 January.

Expedition 339 ended at $1342 \mathrm{~h}$ on 16 January, with the first line ashore in Lisbon, Portugal.

\section{Lithostratigraphy}

Drilling at Site U1391 recovered a $670.98 \mathrm{~m}$ thick sedimentary section (Figs. F3, F4). The shipboard lithostratigraphic program involved detailed visual assessment of grain size, sediment color, sedimentary structures, and bioturbation intensity to describe the facies and facies associations at Site U1391. Petrographic analysis of smear slides taken regularly from Holes U1391A $(n=87)$ and U1391C $(n=44)$ were used to assess average grain size and composition of the sediments to aid in the descriptive sediment classification. Additional smear slides were taken from
Hole U1391B $(n=5)$ at specific locations for correlation with Hole U1391A. Samples were selected from Hole U1391A $(n=37)$ for powder X-ray diffraction (XRD) analysis of bulk mineralogy. No samples were taken from Hole U1391C.

The total carbonate content in these cores, based on shipboard analyses, ranges from 17.5 to $45.2 \mathrm{wt} \%$, although shipboard analyses were only carried out for Hole U1391A (Fig. F5). These results are consistent with the abundance of biogenic carbonate and detrital carbonate estimated from smear slides, so the lithologic names determined from smear slide analyses have been used without modification through this text, the accompanying summary diagrams, and the visual core description sheets. The character of sediment physical properties, including NGR, magnetic susceptibility, color reflectance parameters, and density, records the distribution of these various lithologies and sediment components (see "Physical properties"). Characteristics of the sedimentary sequence cored at Site U1391, together with some of these additional properties, are summarized in Figure F6.

The sedimentary succession at this site is divided into two lithologic units (I and II). Unit I is characterized by only contourite deposits and has been divided into two subunits (IA and IB). Subunit IA is characterized by sandy contourites and alternating reddish/brownish and greenish gray/greenish calcareous mud. Subunit IB is characterized by fewer and finer-grained contourite sequences, all without sand, and has a higher percentage of biosiliceous sediment. Color alternations in the calcareous mud sequences range from greenish gray to greenish. Unit II has a wider range of facies and features, including a debrite, contourites, a dolomitic mudstone, and microfaults. Unit II also shows less color banding than in Unit I.

\section{General description}

\section{Texture}

The sediment is fine grained through most of Site U1391 and dominated by the clay size fraction, with sand-sized material only making a minor contribution to the textural characteristics (Fig. F4). Subunit IA has the lowest clay size fraction (54\%), followed by silt (31\%). Subunit IA also has the highest contribution from the sand size fraction (15\%). Sandy mud and silty sands, at times with biogenic carbonate, have an average grain size from very fine to fine sand with a maximum grain size of medium sand. Silty and sandy units are generally poorly sorted, and detrital siliciclastic grains are subrounded to rounded. 
Detrital carbonate grains are generally subrounded to subangular, and many are abraded, indicating reworking. Subunit IB shows a slight increase in the clay size fraction to $65 \%$ and a decrease in the sand size fraction to $8 \%$. Unit II shows similar textural characteristics to Subunit IB, with clay at $61 \%$ and sand at 9\% (Table T2).

Bioturbation is the most obvious secondary sedimentary structure in cores collected from Site U1391. The most common indicators of bioturbation are diffuse centimeter-scale mottling and millimeter-scale pyritic burrow fills. Black iron sulfide mottling is also common. Discrete burrows and recognizable ichnofossils are rare; those present occur in a few beds with discrete burrows of Chondrites and Zoophycos. The bioturbation index ranges from sparse to slight.

\section{Composition}

All lithologies at Site U1391 are similar in composition, with only subtle changes in abundance between Subunits IA and IB and Unit II (Fig. F4; Table T2). All lithologic units and subunits have a relatively even contribution of terrigenous components including siliciclastics (quartz, feldspars, heavy minerals, clay minerals, and volcanic glass), detrital carbonate, and biogenic components (mainly calcareous nannofossils with rare to common foraminifers). Biogenic silica components are rare but when present include sponge spicules and fragmented radiolarians. Unit II has slightly more biogenic silica than Subunits IA or IB (7\% in Unit II versus 3\% in Unit I; Fig. F4). No discrete ash or dust layers and no dropstones were observed. Authigenic products, such as pyrite (usually classified as opaque mineral grains) and dolomite, are also present in minor amounts throughout Unit I $(<1 \%)$.

Thirty-seven samples were selected from Hole U1391A for powder XRD analysis of bulk mineralogy, and nine samples were processed to show the clay mineralogy of the clay size fraction. Twenty-one of the bulk samples and six of the clay samples were from Subunit IA, and sixteen of the bulk samples and four of the clay samples were in Subunit IB (Fig. F7; Table T3).

\section{Unit/Subunit descriptions}

\section{Subunit IA}

Intervals: 339-U1391A-1H-1, $0 \mathrm{~cm}$, through 22X-6, $10 \mathrm{~cm} ; 339-\mathrm{U} 1391 \mathrm{~B}-1 \mathrm{H}-1,0 \mathrm{~cm}$, through $20 \mathrm{X}-$ CC, $40 \mathrm{~cm}$

Depths: Hole U1391A = 0-196.1 mbsf, Hole $\mathrm{U} 1391 \mathrm{~B}=0-184.5 \mathrm{mbsf}$

Age: Holocene and Pleistocene

\section{Lithologies and bedding}

The dominant lithology is calcareous mud, alternating in places with biogenic mud. Together these lithologies account for $\sim 90 \%$ of the sediment in this subunit. Minor lithologies include calcareous silty mud, calcareous sandy mud, nannofossil mud, and biogenic mud. Calcareous silty sand is rare (Figs. F4, F6).

\section{Structures and texture}

Bi-gradational contouritic sequences are common throughout Subunit IA, with bioturbated and gradational lower and upper contacts and grading from silty clay to silty mud, sandy mud, or silty sand. Some of the bi-gradational sequences have a sharp to erosional contact in the middle of the sequence. In these cases, part of the underlying inversely graded sequence appears to have been removed by downward erosion of the normally graded sequence. The maximum grain size occurs directly above the erosional contact (Figs. F8, F9, F10). Two of these sequences show foraminifer-rich sand in the basal or upper part (Sections 339-U1391A-6H-4 and 6H-6; Figs. F8, F10). A few sequences with sharp bases and normal grading are also described; the maximum grain size is silty mud, sandy mud, or silty sand. A maximum of seven silty and sandy contouritic beds occur per core in Subunit IA (Fig. F4).

\section{Composition}

Subunit IA is dominated by clay-sized (54\%) and siltsized (31\%) sediment. Sand-sized sediment is only a minor component (15\%). Compositionally, the unit has a relatively constant contribution of siliciclastics $(43 \%)$, biogenic carbonate (30\%), and detrital carbonate $(26 \%)$ throughout. Biogenic silica makes only a minor contribution (1\%), except for one specific bed in Section 339-U1391A-11H-3 in which biogenic silica is up to $50 \%$ (Fig. F4).

XRD analyses of 21 bulk samples from Subunit IA record reflections from siliciclastic framework minerals (quartz, K-feldspar, plagioclase, and hornblende), clay minerals (illite, chlorite, kaolinite, and smectite), and carbonates (calcite, dolomite, and rare aragonite). Peak intensities appear fairly constant throughout the subunit. Six clay mineral analyses confirm the presence of smectite in five of the six samples.

\section{Color}

Alternating greenish gray intervals and thicker reddish/brownish intervals are common. In the greenish gray intervals, colors range from dark greenish gray (10Y 4/1 and 5GY 4/1) to greenish gray (10Y 5/1 
and 5GY 5/1). In the reddish/brownish intervals, colors include dark gray $(2.5 \mathrm{Y} 4 / 1)$, dark grayish brown (10YR 4/1 and 2.5Y 4/2), gray (10YR 5/1 and 10Y 6/1), and grayish brown (10YR 5/2 and $2.5 \mathrm{Y} 5 / 2$ ) (Fig. F11). Nannofossil mud has a lighter color range of $10 Y$ 5/1, 5GY 5/1, 10YR 5/1, and 10Y 6/1. Biosiliceous mud is commonly greenish in color (5GY 4/1).

\section{Subunit IB}

Intervals: 339-U1391A-22X-6, $10 \mathrm{~cm}$, through 38X-CC; 339-U1391B-20X-CC, $40 \mathrm{~cm}$, through 38X-CC; 339-U1391C-2R-1, $0 \mathrm{~cm}$, through 25RCC

Depths: Hole U1391A = 196.1-353.5 mbsf (bottom of hole $[\mathrm{BOH}])$, Hole U1391B $=184.5-354.5$ mbsf $(\mathrm{BOH})$, Hole U1391C $=340.0-566.1 \mathrm{mbsf}$

Age: Pleistocene

\section{Lithologies and bedding}

The dominant lithology is calcareous mud, alternating in places with biogenic mud. Together these lithologies account for $\sim 95 \%$ of the sediment in this subunit. The only minor lithology identified is calcareous silty mud (Figs. F4, F6).

\section{Structures and texture}

Subunit IB has rare and widely spaced contouritic sequences with a maximum grain size of silty mud and no sand. Only bi-gradational sequences with bioturbated or gradational upper and basal contacts are observed. There is a maximum of four silty mud contouritic beds per core in Subunit IB (Fig. F4). Millimeter-scale laminations in mud and silty mud are observed at 483-485 mbsf (Sections 339-U1391C17R-3 through 17R-CC) (Figs. F12, F13). The remainder of the unit is described as massive, and sedimentary structures are poorly preserved due to the intensity of bioturbation.

\section{Composition}

Subunit IB has the highest clay size fraction (65\%). Compared to Subunit IA, this subunit has a similar silt size fraction (27\%) and a lower sand size fraction $(8 \%)$. Compositionally, the unit has very even percentages of siliciclastics (32\%), biogenic carbonate $(35 \%)$, and detrital carbonate (30\%). Biogenic silica makes only a minor contribution (3\%), except in seven beds where it occurs with percentages from $10 \%$ to as high as 52\% (Section 339-U1391A-28X-5) (Fig. F4).

The 16 XRD bulk samples from Subunit IB record reflections from siliciclastic framework minerals (quartz, K-feldspar, plagioclase, and hornblende), clay minerals (illite, chlorite, kaolinite, and smectite), and carbonates (calcite, dolomite, and rare aragonite). Peak intensities appear fairly constant throughout the subunit, and are, on average, 30\%$50 \%$ higher than in Subunit IA. Smectite is only present in two of the four analyses.

Color: The most common dark colors are dark greenish gray (10Y 4/1) and greenish gray (10YR 5/1 and $10 Y$ 6/1), alternating with thin greenish intervals (5GY 4/1 and 5GY 5/1) (Fig. F14). These color alternations are quite prominent throughout Subunit IB. The downhole cessation of this color alternation is one of the factors used in determining the boundary with Unit II.

\section{Unit II}

Interval: 339-U1391C-25R-CC, $16 \mathrm{~cm}$, through 36R-CC (bottom of hole)

Depth: 566.10-670.98 mbsf (bottom of hole)

Age: Pliocene

\section{Lithologies and bedding}

The dominant lithology is calcareous mud, alternating with biogenic mud. Together these lithologies account for $\sim 80 \%$ of sediments in this unit. Minor lithologies identified include calcareous silty mud and a dolomitic mudstone (Figs. F4, F6).

\section{Structures and texture}

Unit II has a wider variety of sedimentary structures than does Unit I, including more silty mud contourite sequences. The contourite beds in Unit II are bigradational, several of them with a sharp upper contact (top-cut-out contourite). The base of a debrite ( $\geq 35 \mathrm{~cm}$ thick) occurs at the top of Section 339U1391C-30R-1 (632.6-633.2 mbsf) (Fig. F15; the overlying Core 29R was not recovered). The debrite intraclasts and the matrix are both muddy. The intraclasts show indications of having been burrowed prior to emplacement, are subrounded to rounded, and are as large as a few centimeters in diameter.

A $56 \mathrm{~cm}$ thick dolomitic mudstone bed occurs between 632.6 and 633.2 mbsf (interval 339-U1391C32R-7, 20-76 cm). This sedimentary rock contains abundant fine dolomite grains as well as a few biosiliceous fossils, such as sponge spicules, and rare calcareous nannofossils (Fig. F16). The mudstone bed is overlain by biosiliceous mud. Millimeter-scale laminations of mud and silty mud with biogenic carbonate occur regularly between 634.5 and $650.1 \mathrm{mbsf}$ (Sections 339-U1391C-33R-2 to 34R-5), some of which appear to be low-angle cross-lamination. A reverse microfault offsetting at least two burrows is 
present in Section 339-U1391C-34R-6 (650.1-651.14 mbsf) together with associated dewatering structures (Fig. F17).

\section{Composition}

Unit II comprises a dominant clay size fraction $(60 \%)$, a silt size fraction (31\%), and a minor sand size fraction (9\%). Compositionally, siliciclastics are the dominant component (40\%), and biogenic carbonate $(28 \%)$ and detrital carbonate $(23 \%)$ have a relative equal contribution. Unit II has generally higher biogenic silica (7\%) than Unit I. This is evident throughout Unit II, whereas in Unit I it is present only in discrete beds (Fig. F4). No XRD samples were processed from this unit.

\section{Color}

Unit II displays a dominant greenish gray background color (10Y $4 / 1$ and $10 \mathrm{Y} 5 / 1)$ that alternates with thin and less common $(n=6)$ greenish intervals (5GY 4/1).

\section{Discussion}

Textual and compositional characteristics are very uniform throughout Site U1391. Accordingly, lithologic unit and subunit division is based on subtle variations in composition and facies characteristics. Specifically, Subunit IA is characterized by cyclic color alternation between reddish gray and greenish gray. This subunit also contains more silty mud and silty sand units than the underlying units. These silty units have been interpreted as parts of contourite sequences. Stacked contourite sequences are relatively common with top- and/or base-cut-out sequences. Erosional or sharp contacts are common within these stacked sequences, indicating changes in current velocity. Subunit IA correlates with formal and informal Subunit IA at Sites U1386, U1387, and U1389.

Subunit IB has fewer distinct contourite sequences and is dominated by thick beds of calcareous muds with green mottles, some of which are rich in biogenic silica (diatoms and sponge spicules), and laminated. Subunit IB clearly represents a low-energy contourite depositional environment, and the preservation of lamination in parts of the subunit probably indicates periodically decreased oxygenation of the bottom waters resulting in less biological activity (a decrease in bioturbation).

In Unit II (Pliocene), the alternating successions of reddish and green calcareous muds are less obvious and more irregular, suggesting some change in the controls on cyclicity. The dolomitic mudstone in Unit II occurs at a similar stratigraphic position as that observed at Site U1387, and we would interpret a similar formation mechanism linked with a hiatus in sedimentation. This is clear evidence for widespread strong bottom current activity linked with MOW intensification at 3 Ma.

Debrites and microfaulting are also present in Unit II, the latter perhaps indicative of slump/slide processes. Both deformation features indicate slope instability and downslope mass movement that might be related to regional tectonic activity.

\section{Biostratigraphy}

Sediments at Site U1391 date from the Holocene to the late Pliocene (Fig. F18; Table T4), with the base age of Hole U1391C estimated to span between 3.31 and 3.5 Ma. Site U1391 shows a continuous record with some changes in sedimentation rates. For the Pleistocene, from the seafloor to $\sim 1.5 \mathrm{Ma}$, a sedimentation rate of $27 \mathrm{~cm} / \mathrm{k} . \mathrm{y}$. was estimated, whereas during the early Pleistocene (1.5-2.588 Ma), it is 17 $\mathrm{cm} / \mathrm{k} . \mathrm{y}$. The Pliocene records the lowest values with an estimation of $13 \mathrm{~cm} / \mathrm{k} . \mathrm{y}$.

The microfossil content of sediment recovered at Site U1391 is usually high. The samples are rich in planktonic and benthic foraminifers as well as calcareous nannofossils (Tables T5, T6). Ostracods are present but were not studied in this site.

Pollen and spores are abundant in the eight samples analyzed in Holes U1391A and U1391C. Total pollen and spore concentrations range from $\sim 12,000$ to 48,000 grains $/ \mathrm{cm}^{3}$, excluding Sample 339-U1391A$35 \mathrm{X}-\mathrm{CC}$ in which the amount is surprisingly an order of magnitude higher, exceeding 170,000 grains $/ \mathrm{cm}^{3}$. The preservation of the grains is mostly good to moderate. The proportion of unidentifiable grains progressively increases downhole, as is the case at Sites U1387, U1389, and U1390 (see Fig. F26 in the "Site U1387" chapter, Fig. F22 in the "Site U1389" chapter, and Fig. F21 in the "Site U1390" chapter [Expedition 339 Scientists, 2013d, 2013e, 2013f]). We also observed microcharcoal particles and dinocysts.

\section{Calcareous nannofossils}

We examined all core catcher samples from Holes U1391A-U1391C for calcareous nannofossil biostratigraphy. Additionally, selected samples from Hole U1391A were analyzed in order to constrain biohorizons, paying attention only to marker species. Calcareous nannofossil assemblages are very abundant to common and diverse, and the preservation is good to moderate. Small placoliths $(<3 \mu \mathrm{m})$ and occasionally medium placoliths $(3-5 \mu \mathrm{m})$ dominate the assemblages. 
In total, 12 Pleistocene and Pliocene nannofossil datums defined and/or calibrated by Raffi et al. (2006 and references therein) and Flores et al. (2010) were identified in the holes (Table T4). Inorganic input and reworking of early Neogene and Paleogene species vary from few to common throughout all sections (Table T5).

The change in abundance of large Emiliania huxleyi $(>4 \mu \mathrm{m})$ that characterizes Termination 1 in mid- to low-latitude water masses in the Atlantic Ocean has been proven as a useful event by Flores et al. (2010). This change in abundance was recorded between Samples 339-U1391A-1H-2, $142 \mathrm{~cm}$, and 1H-3, 60 $\mathrm{cm}$ (2.92-3.60 mbsf), and between the top of Hole U1391B to $1 \mathrm{H}-\mathrm{CC}$ (0-9.61 mbsf), making it possible to distinguish the onset of the Holocene.

The first occurrence (FO) of E. huxleyi (0.26 Ma), which marks the base of Zone NN21, was placed between Samples 339-U1391A-8H-CC and 9H-1, $75 \mathrm{~cm}$ (70.18-71.35 mbsf), and between 339-U1391B-7H$\mathrm{CC}$ and $8 \mathrm{H}-\mathrm{CC}$ (67.07-76.94 mbsf). However, this event should be taken with caution because of dissolution effects and the low proportion of this species. The last occurrence (LO) of Pseudoemiliania lacunosa (0.46 Ma), considered a globally synchronous event that defines the top of Zone NN19, occurs between Samples 339-U1391A-13H-5, $75 \mathrm{~cm}$, and 13H-6, 75 cm (114.57-115.95 mbsf), and between 339-U1391B12H-CC and 13H-CC (114.83-123.75 mbsf).

A biohorizon considered useful in Pleistocene sediments is the LO of Reticulofenestra asanoi (0.90 Ma), which was placed between Samples 339-U1391A25X-CC and 26X-3, $84 \mathrm{~cm}$ (227.46-231.11 mbsf), and between 339-U1391B-25X-CC and 26X-CC (231.21-240.53 mbsf). The FO of $R$. asanoi (1.07 Ma), another significant event for the Pleistocene, was recorded between Samples 339-U1391A-32X-5, $60 \mathrm{~cm}$, and 32X-7, $60 \mathrm{~cm}$ (291.84-294.70 mbsf), and between 339-U1391B-32X-CC and 33X-CC (298.63$308.79 \mathrm{mbsf})$. To define these biohorizons, we considered specimens of $R$. asanoi $\geq 6 \mu \mathrm{m}$ in size.

The LO of large Gephyrocapsa spp. (>5.5 $\mu \mathrm{m})(1.24$ Ma) was recorded between Samples 339-U1391A36X-CC and 37X-1, $75 \mathrm{~cm}$ (334.10-343.25 mbsf), and between 339-U1391B-35X-CC and 36X-CC (328.74-338.45).

The LO of Helicosphaera sellii (1.25 Ma) was identified between Samples 339-U1391A-37X-CC and 38XCC $(343.25-353.10 \mathrm{~cm})$ and between 339-U1391B35X-CC and 36X-CC (328.74-338.45 mbsf). This event is considered diachronous (Raffi et al., 1993; Wei, 1993). However, the occurrence of $H$. sellii at this site is consistent with the ages provided by Raffi et al. (2006) for the Mediterranean Sea when compared with other calibrated events.

The FO of large Gephyrocapsa spp. (>5.5 $\mu \mathrm{m})(1.61$ Ma) was identified between Samples 339-U1391C7R-CC and 8R-CC (391.49-399.92). The LO of Calcidiscus macintyrei (1.66 Ma) was placed between Samples 8R-CC and 9R-CC (399.92-412.14 mbsf).

The genus Discoaster is rare in Hole U1391C, however, it is possible to recognize some bioevents. The LO of Discoaster brouweri (1.95 Ma), defining the boundary of Zones NN18 and NN19, occurs between Samples 339-U1391C-15R-CC and 16R-CC (470.36$478.52 \mathrm{mbsf})$.

The LO of Discoaster surculus (2.53 Ma) is an event useful to approximate the Pleistocene/Pliocene boundary. This bioevent was identified between Samples 339-U1391C-24R-CC and 25R-CC (556.62$566.10 \mathrm{mbsf})$. The LO of Discoaster tamalis (2.8 Ma), another species with low abundance at this site, was placed between Samples 28R-CC and 30R-CC (594.85-613.97 mbsf). These events should be taken with caution because of the scarcity of the species used for its definition.

\section{Planktonic foraminifers}

Planktonic foraminifers were studied in all core catcher samples from Holes U1391A-U1391C. Planktonic foraminifers are abundant and well preserved in most samples (Table T6).

Planktonic foraminifer assemblages dominated by Neogloboquadrina pachyderma (sinistral), Turborotalita quinqueloba, and Globigerina bulloides, typically living in polar to subpolar waters today, are replaced by those dominated by Globigerinodes ruber, including the pink morphotype, Globigerinoides trilobus, and Globigerinoides sacculifer, which are characteristic of warmer waters prevalent during interglacial or interstadial periods. Sample 339-U1391A-1H-CC, taken at 4.16 mbsf, contains abundant N. pachyderma (sinistral), and therefore we relate it to a Heinrich event, very likely Heinrich Event 1, constraining the depth of the Holocene to the upper part of Core 339U1391A-1H. In many samples, especially in glacial periods, G. bulloides is very abundant, indicating high productivity conditions. Deep-dwelling foraminifers, typically Globorotalia truncatulinoides and/ or Globorotalia crassaformis, were observed in many samples, especially in interglacial periods (Table T6). No evidently reworked foraminifers were found at this site.

In Holes U1391A and U1391B, only one biostratigraphic event, the top of the paracme of $N$. pachyderma (sinistral), has been observed. This event, de- 
fined by the reappearance of the species in marine isotope stage (MIS) 36 (1.21 Ma; Lourens et al., 2004; Raymo et al., 1989; Sierro et al., 2009) (Table T6), was observed between Samples 339-U1391A-35X-CC and 36X-CC (324.44-334.10 mbsf) and between 339U1391B-34X-CC and 35X-CC (318.90-328.74 mbsf).

Large, heavily encrusted specimens of Neogloboquadrina atlantica (dextral) have been observed in other sites of this expedition occurring at $\sim 1.3 \mathrm{Ma}$, always within the paracme of $N$. pachyderma (sinistral). In Holes U1391A and U1391B, such specimens are missing, indicating that the bases of these holes are probably younger than 1.3 Ma. However, this event was observed in Hole U1391C between Samples 339U1391C-5R-CC and 15R-CC (374.53-470.36 mbsf).

The FO of Globorotalia inflata, $(2.09 \mathrm{Ma}$; Lourens et al., 2004), was placed between Samples 339-U1391C18R-CC and 19R-7, 0-5 cm (498.75-507.95 mbsf) (Table T4).

For the first time during this expedition, the LO of $N$. atlantica (sinistral) (2.41 Ma; Weaver and Clement, 1987) was observed between Samples 339-U1391C23R-CC and 24R-CC (546.94-556.62 mbsf).

The LO of Globorotalia puncticulata (2.41 Ma; Hilgen, 1991; Lourens et al., 2004), was observed between Samples 339-U1391C-24R-CC and 25R-CC (556.62$566.10 \mathrm{mbsf}$ ).

The coiling change in $G$. crassaformis from sinistral to dextral (2.99 Ma; Zachariasse et al., 1989; Berggren et al., 1995; Lourens et al., 2004; L. Lourens, pers. comm., 2012) that was also observed at Site U1389 (see "Biostratigraphy" in the "Site U1389" chapter [Expedition 339 Scientists, 2013e]) was placed between Samples 339-U1391C-28R-CC and 30R-CC (594.85-613.97 mbsf) (Table T4).

The LO of Sphaeroidinellopsis seminulina (3.19 Ma; Lourens et al., 2004) was found between Samples 339-U1391C-33R-5, 32-34 cm, and 33R-6 (639.55$641.6 \mathrm{mbsf})$, occurring, as in the Mediterranean and at Site U1389, during an interval of dextral coiling $G$. crassaformis (Zachariasse et al., 1989). The LO occurs below the dolostone (see "Lithostratigraphy"), confirming the basal age obtained for the dolostone and associated hiatus at Site U1387. The age of this event is well constrained (Lourens et al., 2004), and its offset from the general sedimentation rate line in Figure F18 points to a potentially lower sedimentation rate between the coiling change in G. crassaformis at 2.99 Ma and the LO of S. seminulina at 3.19 Ma.

The top of the temporal disappearance of G. puncticulata (3.31 Ma; Lourens et al., 2004) was recorded between Samples 339-U1391C-34R-CC and 36R-CC (652.11-670.98 mbsf) and constrains the base age of Hole U1391C.

\section{Benthic foraminifers}

A total of 28 samples between Sections 339-U1391A$1 \mathrm{H}-\mathrm{CC}$ and 38X-CC and 20 samples between Sections 339-U1391C-2R-CC and 36R-CC were analyzed for benthic foraminiferal assemblages (Table T7). Benthic foraminifers are well preserved and abundant.

The benthic foraminiferal fauna is mainly composed of species of Brizalina, Bulimina, Cassidulina, Cibicidoides, Globobulimina, Melonis, Siphonodosaria, Sphaeroidina, and Uvigerina in varying proportions. Based on major fluctuations in Brizalina spp., Cibicides/Cibicidoides spp., and Siphonodaria spp., three assemblages can be distinguished that suggest variations in upwelling intensity, ventilation, and/or MOW current strength and that alternate throughout the succession:

1. Assemblages with high amounts of Brizalina spp. characterize environments with increased organic matter flux and reduced ventilation and are most likely linked to intensified upwelling along the Western Iberian margin (Samples 339U1391A-1H-CC through 16H-CC, 339-U1391C7R-CC through 14R-CC, and 27R-CC through 33R-CC) (van Morkhoven et al., 1986; Leckie and Olson, 2003; Murray, 2006).

2. Assemblages with high abundances of Cibicides/ Cibicidoides spp. that parallel low abundances of Brizalina spp. indicate improved bottom water oxygenation and increased ventilation (Samples 339-U1391A-18H-CC through 34X-CC and 339U1391C-36R-CC) (Kaiho, 1999; Murray, 2006).

3. Assemblages between Samples 339-U1391A-35XCC and 38X-CC and 339-U1391C-2R-CC through 6R-CC reveal high abundances of Siphonodosaria spp. associated with variable amounts of Cibicidoides cf. wuellerstorfi, Melonis spp., Sigmoilopsis schlumbergeri, and Uvigerina spp. The faunal composition indicates high organic matter input with variable oxygen conditions (Kaiho, 1999; Kawagata et al., 2005; Murray, 2006). It is worthy to note that these assemblages show similarities to the lower part of Site U1385 (Samples 339-U1385A-12X-CC through 17X-CC; see Table T7 in the "Site U1385 chapter [Expedition 339 Scientists, 2013c]), which has high abundances of stilostomellids, nodosariids, and pleurostomellids in general and regular occurrences of $\mathrm{Myl}$ lostomella fijiensis and Siphonodosaria lepidula in particular. The latter species are rare or absent at Sites U1386-U1390 in the Gulf of Cádiz.

The "epibenthos group," which has been suggested as an indicator for MOW intensity in the area (Schönfeld, 1997, 2002; Schönfeld and Zahn, 2000), 
is generally rare at Site U1391, potentially resulting from the location in a distal portion of MOW.

The "Stilostomella extinction" event (0.58-0.7 Ma; Hayward, 2002; Kawagata et al., 2005) was placed between Samples 339-U1391A-21X-CC and 22X-CC (189.27-199.40 mbsf) based on the last common occurrence of stilostomellids, nodosariids, and pleurostomellids. However, individual shells occur in Samples 20X-CC and 19X-CC. This datum agrees well with the age constraints by the nannoplankton assemblages.

\section{Palynology}

Eight samples, six from Hole U1391A (Samples 1HCC, 7H-CC, 14H-CC, 21X-CC, 28X-CC, and 35XCC) and two from Hole U1391C (Samples 5R-CC and 15R-CC), were analyzed (Table T8).

A problem in the sample preparation could account for the high concentration value, 170,000 grains $/ \mathrm{cm}^{3}$, found in Sample 339-U1391A-35X-CC. The sample is characterized by very fine clay, the dominance of semidesert plants, and one of the first occurrences of N. pachyderma (sinistral), can be assigned to MIS 36 or 34 (see above). This sample had to be sieved several times through the $10 \mu \mathrm{m}$ sieve in order to concentrate the pollen grains. This methodology could have biased the known concentration of Lycopodium spores. However, the same protocol has been applied to proximate and similarly very fine clay Samples 339-U1391C-5R-CC and 15R-CC, which in contrast show similar concentration values to the other samples from this site. Therefore, other reasons that may relate to particular environmental and geomorphological conditions of one of these early Quaternary glacial periods in this region could explain the high pollen concentration of Sample 339-U1391A-35XCC.

Besides that, the very low resolution pollen record reflects (Fig. F19), as at the previous sites (see "Biostratigraphy" in the "Site U1385" chapter and "Biostratigraphy" in the "Site U1390" chapter [Expedition 339 Scientists, 2013c, 2013f]), the alternating dominance of the four main plant ecological groups which characterize this region, Pinus, Mediterranean forest, semidesert, and grasslands, during the last 1.5 m.y. In particular, the high abundance of semidesert plants in the uppermost sample (339-U1391A-1HCC) at the expense of the Mediterranean forest, heathlands, and grasslands allows us to assign this level to one of the most recent Heinrich stadials, as identified in the nearby Core SU81-18 (Turon et al., 2003).

\section{Paleomagnetism}

Paleomagnetic investigation of the 112 APC, XCB, and RCB cores (excluding 1 wash core and 4 cores without recovery) collected at Site U1391 included the measurement of magnetic susceptibility of whole-core and archive-half split-core sections and natural remanent magnetization (NRM) of archivehalf split-core sections before and after alternating field (AF) demagnetization with $20 \mathrm{mT}$ peak field. NRM before demagnetization was measured on Cores 339-U1391A-1H through 38X and 339U1391B-1H through 24X but was discontinued because of time constraints at the end of the expedition. The FlexIt tool was used to orient 32 cores in the APC sections of Holes U1391A and U1391B, starting with Core $4 \mathrm{H}$ in Hole U1391A and $3 \mathrm{H}$ in Hole U1391B. The APC core orientations for Holes $\mathrm{U} 1391 \mathrm{~B}$ and U1391C are provided in Table T9 and used for APC core reorientation (Fig. F20). We processed data extracted from the Laboratory Information Management System database by removing all measurements that were made within intervals with interstitial water samples, intervals that contain voids as summarized in the core descriptions, anomalous intervals noted during measurement, and 10 $\mathrm{cm}$ of the section ends, which are slightly biased by measurement edge effects. The processed NRM inclination, declination (including the FlexIt tool corrected declination for Holes U1391A and U1391B), and intensity data after $20 \mathrm{mT}$ peak field AF demagnetization are listed in Tables T10, T11, and T12.

\section{Natural remanent magnetization and magnetic susceptibility}

The intensity of NRM after $20 \mathrm{mT}$ peak field AF demagnetization is similar in magnitude in the overlapping parts of Holes U1391A-U1391C, ranging from $\sim 10^{-5}$ to $\sim 10^{-2} \mathrm{~A} / \mathrm{m}$ (Fig. F20, third panel). Sediments from the uppermost 105 mbsf exhibits the highest NRM intensities, on the order of $10^{-2} \mathrm{~A} / \mathrm{m}$, with a mean of $\sim 0.014 \mathrm{~A} / \mathrm{m}$. Below $\sim 105 \mathrm{mbsf}$, magnetic intensities are variable but generally lower than those in the uppermost part of the section (mean value $=\sim 0.0024 \mathrm{~A} / \mathrm{m})$.

Despite the coring disturbance and drill string overprint in the XCB-cored sections, a relatively stable magnetic component was preserved in sediment from all holes, allowing for the determination of magnetic polarity for most parts of the recovered sedimentary sequences. The XCB sections in Holes U1391A and U1391B are often heavily biscuited and 
frequently contain as much of the disturbed matrix as the intact material, severely compromising the quality of the resulting paleomagnetic data.

Magnetic susceptibility measurements were made on whole cores from all three holes as part of the Whole-Round Multisensor Logger (WRMSL) analysis and on archive-half split-core sections using the Section Half Multisensor Logger (SHMSL) (see "Physical properties"). Magnetic susceptibility is consistent between the two instruments and, in general, parallels the intensity of magnetic remanence. WRMSL susceptibility was stored in the database in raw meter units. These were multiplied by a factor of $0.68 \times 10^{-5}$ to convert to the dimensionless volume SI unit (Blum, 1997). A factor of $(67 / 80) \times 10^{-5}$ was multiplied by the SHMSL acquired susceptibility stored in the database. Magnetic susceptibility varies between $5 \times 10^{-5}$ and $40 \times 10^{-5}$ SI (Fig. F20, fourth panel). Susceptibility in the uppermost $\sim 105 \mathrm{~m}$ of sediments (mean value is $20 \times 10^{-5} \mathrm{SI}$ ) is higher than that of sediments below that level (mean value $=\sim 10 \times 10^{-5}$ SI. Note that in Figure F20, a constant of $25 \times 10^{-5}$ SI was added to the SHMSL measurements (gray lines) to facilitate the comparison with the WRMSL measurements (black lines).

\section{Magnetostratigraphy}

We used magnetic inclinations, and FlexIt tool corrected declinations when available, to interpret magnetostratigraphy for the APC-cored sediment sequences. The lack of core orientation and significant coring disturbance, as well as drill string overprint in the XCB and RCB cores, limit our magnetostratigraphic interpretation for the XCB- and RCB-cored sediments in Holes U1391A and U1391B to relying on magnetic inclination changes. The geomagnetic field at the latitude of Site U1391 $\left(37.56^{\circ} \mathrm{N}\right)$ has an expected inclination of $56.78^{\circ}$, assuming a geocentric axial dipole field model, which is sufficiently steep to determine magnetic polarity in cores that lack horizontal orientation.

NRM inclination data (after $20 \mathrm{mT}$ peak field AF demagnetization) from all three holes indicate that the uppermost $\sim 170 \mathrm{~m}$ of sediment was deposited during the Brunhes Chron (C1n) (Fig. F20). This interpretation is consistent with the LO of P. lacunosa (0.47 Ma) at $\sim 114.68$ and $\sim 118.75$ mbsf and the LO of $R$. asanoi $(0.9 \mathrm{Ma}$ ) at 229.28 and $235.87 \mathrm{mbsf}$ in Holes U1391A and U1391B, respectively (see "Biostratigraphy"). The remainder of the XCB sections in Holes U1391A and U1391B is heavily disturbed and overprinted, and although several intervals reveal a clear reversed or normal polarity pattern, it is impossible to assign them to parts of the geomagnetic polarity timescale without the analysis of discrete samples from the XCB biscuits.

The top of the RCB-cored section of Hole U1391C records the lower part of the Matuyama Chron (C1r.2r) and, surprisingly well, the top ( 452-463 mbsf) and bottom ( $486 \mathrm{mbsf})$ of the Olduvai Subchron (C2n). This interpretation is constrained by the LOs of $C$. macintyrei (1.66 Ma) and D. broweri (1.95 Ma) at 406 and 474 mbsf, respectively (see "Biostratigraphy"). The long normal polarity interval between $\sim 575$ mbsf and the base of Hole U1391C is assigned to the Gauss normal chron. This interpretation is supported by the LO of $D$. surculus $(2.53 \mathrm{Ma})$ at $\sim 561$ mbsf and the LO of D. tamalis $(2.80 \mathrm{Ma})$ at $\sim 604$ mbsf. Shorter subchrons of the geomagnetic polarity timescale, such as the Reunion or the Kaena, could not be resolved. The resolved polarity boundaries at Site U1391 are summarized in Table T13.

\section{Physical properties}

The shipboard physical properties program at Site U1391 included high-resolution nondestructive measurements of gamma ray attenuation (GRA) bulk density, magnetic susceptibility, and $P$-wave velocity mostly in $2.5 \mathrm{~cm}$ steps on the WRMSL. NGR on whole-round core sections was measured at 10 and $20 \mathrm{~cm}$ spacing, depending on the time available. The Special Task Multisensor Logger was only used in Hole U1391B for stratigraphic correlation purposes. Thermal conductivity was obtained on Section 3 of each core in Hole U1391A until Core 19H. Discrete measurements of $P$-wave velocities were determined on working-half sections, one every other section in Hole U1391A. However, reasonable results were only obtained for the upper 50 mbsf. Moisture and density (MAD) samples were measured for every second section of each core in Holes U1391A and U1391C. Color reflectance spectrometry and split-core pointlogger magnetic susceptibility were obtained for every section in each hole in $5 \mathrm{~cm}$ steps.

Based on the physical property data, we can distinguish four units (Figs. F21, F22). Physical properties Unit I, from 0 to $\sim 155 \mathrm{mbsf}$, is characterized by a clear positive correlation between NGR, magnetic susceptibility, and $\mathrm{a}^{*}$. The color reflectance measurement $a^{*}$ is generally very variable and includes positive (reddish) values. Physical properties Unit II, between 155 and $200 \mathrm{mbsf}$, is characterized by low magnetic susceptibility and a marked negative correlation between NGR and $\mathrm{a}^{*}$. Physical properties Unit III, from 200 to 560 mbsf, exhibits low magnetic susceptibility values and a positive correlation between NGR, magnetic susceptibility, and GRA density. The correlation between magnetic susceptibility and 
NGR is particularly pronounced. Conversely, color reflectance measurements $\left(\mathrm{L}^{*}\right.$ and $\left.\mathrm{a}^{*}\right)$ show a positive correlation in several peaks but a complex, unclear relationship when compared with NGR. Below 200 mbsf, $\mathrm{a}^{*}$ values are less variable and exclusively negative. Physical properties Unit IV can be recognized in Hole U1391C downhole from 560 mbsf as a marked reduction in NGR variability and magnetic susceptibility values.

Coinciding with the major change in physical properties at $\sim 200$ mbsf is the boundary between lithostratigraphic Units I and II, which is characterized by more abundant sandy intervals above 200 mbsf (see "Lithostratigraphy"). The color reflectance data is further in agreement with the visual core descriptions, which indicate that alternations of greenish and reddish intervals are only present above $\sim 170$ mbsf, whereas reddish intervals disappear below 200 mbsf.

\section{Whole-Round Multisensor Logger measurements}

GRA bulk density and magnetic susceptibility were measured using the WRMSL in all core sections at $2.5 \mathrm{~cm}$ intervals at Site U1391 after core acclimation for $3 \mathrm{~h}$ (Fig. F21).

\section{Gamma ray attenuation bulk density}

Measured GRA density at Site U1391 ranges between 1.4 and $2.1 \mathrm{~g} / \mathrm{cm}^{3}$ and displays a steady increase in the upper $20 \mathrm{mbsf}$, probably caused by early diagenetic compaction. Downhole, we observed cyclic variations with average values around 1.85 to $1.9 \mathrm{~g} / \mathrm{cm}^{3}$ and distinctive, low-GRA density intervals at 90, 108, 165, and 255 mbsf (Fig. F21A). In Hole U1391C, GRA density reaches a maximum value of $2.4 \mathrm{~g} / \mathrm{cm}^{3}$ at 632 mbsf related to the presence of a dolomitic mudstone (see "Lithostratigraphy") (Fig. F21B).

When GRA density is compared to lithology, no clear correlation can be found. Compared with the other physical properties, a similarity to magnetic susceptibility is present, although it is not as pronounced as observed for the other sites within the Gulf of Cádiz (e.g., Site U1389). In physical properties Unit III, from 200 to 560 mbsf, a moderately strong positive correlation can be found between GRA density and NGR.

\section{Magnetic susceptibility}

The most notable aspects of the magnetic susceptibility records in Hole U1391A are a sharp decrease at 28 mbsf (from $65 \times 10^{-5}$ SI to $\sim 10 \times 10^{-5}$ SI) and cyclic variations ranging from $5 \times 10^{-5}$ to $60 \times 10^{-5}$ SI between 28 mbsf and the lower boundary of physical properties Unit I. Generally, low values are found in physical properties Units II and III (mostly $<20 \times 10^{-5}$ SI), and a further decrease can be observed in physical properties Unit IV, with values usually $<10 \times 10^{-5}$ SI downhole (Fig. F21).

Magnetic susceptibility records at Site U1391 show a clear positive correlation with NGR data. This relationship becomes remarkably good below $\sim 155$ mbsf. In physical properties Unit I (0-155 mbsf), magnetic susceptibility is sensitive to the presence of sands, although with a complex pattern. For example, sandy layers in Sections 339-U1391A-6H-4 and 6H-6 exhibit low magnetic susceptibility in their lower parts and an abrupt shift to high values in the upper parts. Sharp compositional changes are described within these two sandy layers (see "Lithostratigraphy"). However, no correlation of magnetic properties can be found in relation to sand layers in the other physical properties units (e.g., sand layers in Cores 339-U1391A-22X and 30X).

Low magnetic susceptibility values through physical properties Units II, III, and IV could be explained by the reduction of fine-grained magnetite to Fe sulfides below the sulfate reduction zone. However, the present sulfate-methane transition zone occurs at a shallower depth of $\sim 20$ mbsf (see "Geochemistry"). A link between magnetic susceptibility and diagenetic processes could occur in physical properties Unit IV, where the decrease in magnetic susceptibility might relate to a large increase in alkalinity and the inferred presence of gas hydrate at roughly the same depth.

\section{$\boldsymbol{P}$-wave velocity}

Sonic velocities were measured with the WRMSL in Hole U1391A, and an attempt was made to determine $P$-wave velocities on split cores in each section of Hole U1391A (Fig. F21A). Because of poor sediment to liner coupling, reasonable results from the WRMSL could only be obtained for the upper $\sim 45$ mbsf. The $P$-wave velocity profile can be extended downhole to 50 mbsf by using the $P$-wave measurements on split cores. Although the sediment surface appeared to be smooth and should have provided an adequate coupling to the transducers, no clear acoustic signal could be obtained at greater depths. An explanation for this might be the formation of small cracks in the relatively stiff and brittle sediment that negatively affects signal propagation through the sediment. Additionally, small voids between sediment and liner might prevent a sharp signal from being received by the transducer touching the liner. 
$P$-wave velocities follow the trend of increasing GRA density in the upper $10 \mathrm{mbsf}$. Downhole values range from 1400 to $1650 \mathrm{~m} / \mathrm{s}$ for WRMSL and splitcore data (only accounting for automatically processed data). Values obtained by both types of measurements agree well, especially when only considering split-core data with high signal quality (solid symbols in Fig. F21A).

\section{Natural gamma radiation}

Measured values of NGR range from 20 to $55 \mathrm{cps}$, revealing cyclic patterns that are more abrupt than regular oscillations in physical properties Units I, II, and III (Fig. F22). In physical properties Unit IV, NGR decreases in variability between 30 and $45 \mathrm{cps}$ and lacks distinct peaks (Fig. F22B).

NGR data do not show a clear correlation with grain size variations, which might indicate that detrital potassium and thorium are present independent of grain size variations. Notably, an almost perfect correlation exists between NGR and magnetic susceptibility, and a negative correlation with exists $a^{*}$ in physical properties Unit II.

\section{Moisture and density measurements}

Determination of moisture content and density on discrete sediment samples was made on every second section of Hole U1391A (Fig. F23). Samples were consistently taken at $\sim 60 \mathrm{~cm}$ intervals. Generally, GRA and MAD methods give consistent density results, with slightly lower values for MAD in the upper 20 mbsf of Hole U1391A (Fig. F23A).

The compaction-related downhole moisture and porosity decrease follows a characteristic pattern. Rapid compaction can be recognized in the upper 2 mbsf, with a decrease in porosity from $70 \%$ to $60 \%$ and moisture content from $40 \%$ to $30 \%$. More progressive compaction occurs from 2 to $\sim 30 \mathrm{mbsf}$, where values reach $30 \%$ moisture and $55 \%$ porosity. This variation in compaction mode can be related to the different sediment composition and texture and might be a result of changes in the sedimentation rate. Below 30 mbsf in physical properties Unit I, we observed two long-wavelength cyclic variations between $25 \%$ and $30 \%$ in moisture content and $45 \%$ and $55 \%$ in porosity. Grain density shows an inverse correlation with these cyclic changes, which might indicate that these cycles are controlled by carbonate content.

In physical properties Unit II (155-200 mbsf), two peaks in porosity and moisture content can be recognized. The previously recognized anticorrelation to grain density appear to be more complex in this unit. Throughout physical properties Unit PPIII, high-amplitude cyclicity appears to be superimposed upon other low- and high- amplitude oscillations. Grain density values are highly variable from 420 mbsf to the lowermost core, with sharp variations between 2.85 and $2.65 \mathrm{~g} / \mathrm{cm}^{3}$. This interval is characterized by a slightly increased abundance of sandy intervals, which might explain the larger scatter of the grain density data. Data below 500 mbsf are not available because of time constraints at the end of the expedition.

\section{Thermal conductivity}

Thermal conductivity was measured once per core using the full-space probe, usually in Section 3 near the middle of sections downhole to Core 339U1391A-19H (see "Downhole measurements"). Because cores retrieved using XCB drilling are severely disturbed and affected by biscuiting, thermal conductivity measurements were only taken on APC cores. Thermal conductivity varies between 1.1 and $1.6 \mathrm{~W} /(\mathrm{m} \cdot \mathrm{K})$, which is in the range observed at the other sites. In the upper $30 \mathrm{mbsf}$, thermal conductivity values show a low range of variation (1.1-1.3 $\mathrm{W} /[\mathrm{m} \cdot \mathrm{K}])$. Below $30 \mathrm{mbsf}$, no clear trend is imprinted in the data; however, more prominent variations appear between cores that reach the highest and lowest values. A weak correlation to moisture content and porosity can be recognized between Cores 339-U1391A-4H and 9H, in which relatively high moisture and porosity values appear to correlate with high thermal conductivity values. For the other cores, the relationship between thermal conductivity and other parameters is not evident, although pore water content should have an effect on thermal conductivity.

\section{Summary of main results}

Correlation of physical property data allows us to discern four physical properties units at Site U1391 with boundaries at 155, 200, and 560 mbsf. The boundary at 200 mbsf matches with a change in the abundance of sandy beds in the mud-dominated sediment (lithostratigraphic Units I and II). In general, a coherent relationship exists between high magnetic susceptibility, NGR, and GRA density. Especially notable is the excellent correlation between NGR and magnetic susceptibility below $\sim 155 \mathrm{mbsf}$. The presence of coarse layers is, if at all, inconsistently expressed in the measured physical parameters. However, major changes in physical properties are evident in apparently homogeneous calcareous mud deposits. The varying (i.e., positive as well as negative) correlation of NGR and magnetic susceptibility in relation to color changes suggests that the associated changes in mineralogical composition are of a 
different nature in this location when compared with previous reddish layers described during this expedition.

\section{Geochemistry Volatile hydrocarbons}

Headspace gas analysis was performed as a part of the standard protocol required for shipboard safety and pollution prevention monitoring. In total, 34 headspace samples from Hole U1391A (sampling resolution of one per core) and 32 samples from Hole U1391C were analyzed (Fig. F24; Table T14), spanning the entire depth range of the site. In both Holes U1391A and U1391C, we detected methane $\left(C_{1}\right)$, ethane $\left(\mathrm{C}_{2}\right)$, ethene $\left(\mathrm{C}_{2=}\right)$, propane $\left(\mathrm{C}_{3}\right)$, and propene $\left(\mathrm{C}_{3=}\right)$. Methane ranges from $5.4 \mathrm{ppmv}$ near the surface to a maximum of $41,703 \mathrm{ppmv}$ at $69.9 \mathrm{mbsf}$ (Section 339-U1391A-8H-7). Below this depth, methane displays a decreasing trend, reaching 1,276 ppmv at the base of Hole U1391C. Ethane, ethene, propane, and propene were all detected in both holes, but concentrations remained low. All $\mathrm{C}_{2}$ and $\mathrm{C}_{3}$ hydrocarbons do not exceed 8 ppmv for the entire depth profile. Ethane does not exceed $7.1 \mathrm{ppmv}$, ethene does not exceed $2.6 \mathrm{ppmv}$, propene does not exceed $0.6 \mathrm{ppmv}$, and propane does not exceed 4.8 ppmv.

\section{Sedimentary geochemistry}

Sediment samples were collected for analysis of solid-phase geochemistry (inorganic and organic carbon) at a resolution of approximately one sample per core in Hole U1391A (Table T15); however, because of time constraints at this final site of the expedition, we could not analyze samples below $351 \mathrm{mbsf}$. $\mathrm{CaCO}_{3}$ varies from 17.5 to $45.2 \mathrm{wt} \%$ (Fig. F25). The range is comparable, albeit greater, than the $\mathrm{CaCO}_{3}$ variability measured at nearby Site U1385. Organic carbon varies between 0.5 and $1.8 \mathrm{wt} \%$ (Fig. F26A), with no discernible trends at this resolution.

Nitrogen (Fig. F26B) was measured downhole to 351 mbsf in Hole U1391A and ranges from 0.06 to 0.1 wt $\%$. We did not observe any notable trends in nitrogen content with depth. The $\mathrm{C} / \mathrm{N}$ ratio, used to distinguish the origin of organic matter (marine versus terrestrial) in sediment, varies between 7 and 22, indicating that the organic carbon is mainly of marine origin with a terrestrial component of varying contribution (Fig. F26C). Samples with a $\mathrm{C} / \mathrm{N}$ ratio exceeding 10 indicate the presence of some terrestrial input, whereas those over 20 are predominantly terrestrial (Emerson and Hedges, 1988; Meyers, 1997).
The terrestrial component calculated at Site U1391 is greater than that measured at Site U1385, which is expected given the closer proximity of Site U1391 to land. Total organic carbon and $\mathrm{C} / \mathrm{N}$ ratios are positively correlated, which agrees with the relationships observed at Sites U1385-U1388 and Site U1390 but is in contrast with the relationship between total organic carbon and C/N at Site U1389.

\section{Interstitial water chemistry}

\section{Major cations and anions}

Sulfate concentrations are near seawater values at the top of the section and decrease to zero at $\sim 20$ mbsf (Fig. F27A; Table T16). At 407.5 and 482.55 mbsf, a small amount of sulfate $(<1 \mathrm{mM})$ was detected, which is likely due to sample contamination from drilling fluid.

Ammonium concentrations increase from $467 \mu \mathrm{M}$ at the surface to $\sim 7,000 \mu \mathrm{M}$ at $204 \mathrm{mbsf}$ (Fig. F27B). Ammonium values remain roughly constant between 204 and 480 mbsf, after which they increase to a maximum of near $11,200 \mu \mathrm{M}$ at $649 \mathrm{mbsf}$.

Alkalinity increases from $8.2 \mathrm{meq} / \mathrm{L}$ near the seafloor to peak values of $15.2 \mathrm{meq} / \mathrm{L}$ at $13 \mathrm{mbsf}$ and decreases to $6 \mathrm{meq} / \mathrm{L}$ at $42 \mathrm{mbsf}$ (Fig. F27C). Alkalinity remains low downhole to $100 \mathrm{mbsf}$, where it increases again to $10 \mathrm{meq} / \mathrm{L}$ at $\sim 150 \mathrm{mbsf}$. Missing alkalinity data between 168 and $223 \mathrm{mbsf}$ is the result of an electrode malfunction. Downhole from $\sim 400$ mbsf, alkalinity begins to rise markedly, reaching values as high as $39.5 \mathrm{meq} / \mathrm{L}$ at $592 \mathrm{mbsf}$.

Calcium, magnesium, and potassium display similar patterns in the upper part of Hole U1391A. All show a sharp decrease from seawater values near the seafloor to lower values between 22 and 32 mbsf. Calcium concentrations decrease from $8.6 \mathrm{mM}$ near the seafloor to a minimum of $2.9 \mathrm{mM}$ at $22 \mathrm{mbsf}$ (Fig. F28A). Magnesium concentration is $52 \mathrm{mM}$ at the seafloor and decreases to $32 \mathrm{mM}$ at $33 \mathrm{mbsf}$ (Fig. F28B). Potassium concentration is $12 \mathrm{mM}$ at the seafloor and decreases to $8.6 \mathrm{mM}$ by $33 \mathrm{mbsf}$ (Fig. F28C). Between 33 and $460 \mathrm{mbsf}$, potassium and magnesium continue to decrease, reaching values of 6.22 and $23.93 \mathrm{mM}$, respectively, at $460 \mathrm{mbsf}$. From $460 \mathrm{mbsf}$ to the base of Hole U1391C, potassium and magnesium increase to 10.44 and $33.5 \mathrm{mM}$, respectively. Calcium concentrations increase in a stepwise pattern from 22 to 241 mbsf. Between 241 and 396 mbsf, calcium varies between 6.7 and $7.8 \mathrm{mM}$. At 396 mbsf, calcium begins to decrease and reaches a minimum value of $2.66 \mathrm{mM}$ at $552 \mathrm{mbsf}$. At 552 mbsf, calcium increases again to $7 \mathrm{mM}$ at $620 \mathrm{mbsf}$ and decreases slightly to reach $\sim 6 \mathrm{mM}$ at the base of Hole U1391C. 
Chloride concentrations are $580 \mathrm{mM}$ at the seafloor and decrease downhole, reaching minimum values of $\sim 545 \mathrm{mM}$ near the base of the site (Fig. F29A). Chloride decreases rapidly from the seafloor to $\sim 70$ mbsf, after which it continues to decline but at a slower rate.

Sodium at Site U1391 shows very high variability, ranging from 460 to $523 \mathrm{mM}$ (Fig. F29B). This rapidly fluctuating signal is unlikely to be real, as it is not observed in any of the other profiles. With this in mind, the variation of $\mathrm{Na} / \mathrm{Cl}$ ratios away from the seawater value of 0.86 (Fig. F29C) is probably largely a function of error in measurement of the sodium concentrations.

\section{Minor elements}

Barium (Fig. F30A) increases from the seafloor to the base of Site U1391. Sharp increases in barium concentration of about $30 \mu \mathrm{M}$ are apparent between the seafloor and 22 mbsf and between 582 and 592 mbsf.

Boron decreases rapidly from $\sim 500 \mu \mathrm{M}$ at the seafloor to $257 \mu \mathrm{M}$ at $146 \mathrm{mbsf}$ (Fig. F30B). The concentration then varies between 208 and $283 \mu \mathrm{M}$ downhole to 533 mbsf. From 533 to 552 mbsf, boron decreases sharply to $185 \mu \mathrm{M}$ and increases to $284 \mu \mathrm{M}$ at $563 \mathrm{mbsf}$, after which it decreases slightly to the base of Hole U1391C.

Iron concentration at Site U1391 decreases sharply from 37 to $1.6 \mu \mathrm{M}$ between the seafloor and $42 \mathrm{mbsf}$ (Fig. F30C). Several sharp increases in iron between $42 \mathrm{mbsf}$ and the base of the hole that are as large as $19 \mu \mathrm{M}$ are evident, but in general, below $42 \mathrm{mbsf}$ the concentration remains close to our detection limit.

Lithium concentrations are $<3 \mu \mathrm{M}$ throughout Site U1391, which is very close to the detection limit (Fig. F31A).

Silicon varies but generally increases from a seafloor value of $320 \mu \mathrm{M}$ to a maximum of $1020 \mu \mathrm{M}$ at 620 mbsf (Fig. F31B). Silicon increases rapidly between 552 and 620 mbsf to $\sim 700 \mu \mathrm{M}$.

Strontium increases smoothly from a seafloor value of 76 to $131 \mu \mathrm{M}$ at $533 \mathrm{mbsf}$ (Fig. F31C). The concentration decreases to $110 \mu \mathrm{M}$ at $553 \mathrm{mbsf}$ and rapidly increases to the base of the site, reaching a maximum of $184 \mu \mathrm{M}$.

\section{Stable isotopes}

Water isotopes were measured only in the upper 200 m of Site U1391 because of time constraints imposed by the end of the expedition (Table T17). At the seafloor, oxygen and hydrogen isotopes are $\sim 0.9 \%$ and $3.8 \%$, respectively, reflecting the lower branch of
MOW. $\delta^{18} \mathrm{O}$ oscillates around a mean value of $0.9 \%$ in the upper $50 \mathrm{mbsf}$ and decreases to a minimum of $0.3 \%$ at $59.3 \mathrm{mbsf}$, followed by an increase between 60 and 89 mbsf to $\sim 1.5 \%$. Below $89 \mathrm{mbsf}, \delta^{18} \mathrm{O}$ decreases, reaching $0.8 \%$ at $127 \mathrm{mbsf}$ and remaining near this value to 187 mbsf. The deepest sample, measured at 194 mbsf, has an even lower value of $0.4 \%$.

$\delta \mathrm{D}$ increases from $3.8 \%$ at the sediment/water interface to $8.7 \%$ at $\sim 42$ mbsf. A distinct minimum in $\delta \mathrm{D}$ occurs at $59.3 \mathrm{mbsf}$, reaching values as low as $1.5 \%$, and followed by an increase in values averaging $5.7 \%$ between 70 and 200 mbsf. The $\delta^{18} \mathrm{O}$ and $\delta \mathrm{D}$ minimum at 59.3 mbsf was replicated by measuring the sample twice. Oxygen and hydrogen isotopes are positively correlated in the upper 115 mbsf (Figs. F32, F33).

\section{Summary}

It is useful to compare the interstitial water results from Site U1391 with those from Site U1385 because the former is influenced by the lower branch of MOW, whereas the latter reflects Northeast Atlantic Deep Water. The sulfate reduction zone is shallower at Site U1391 (20 mbsf) than at Site U1385 (50 mbsf), perhaps reflecting the higher sedimentation rate and accumulation rate of organic matter at Site U1391.

The rapid decrease in chloride in the uppermost 100 mbsf at Site U1391 is similar to the trend at Site U1386, which is located in the upper branch of MOW. Both sites are within MOW, but Site U1391 is in the lower branch.

The decrease of calcium and magnesium in the sulfate reduction zone reflects dolomite formation as a result of high alkalinity produced by sulfate reduction and anaerobic methane oxidation. The increase in calcium and decrease in magnesium below this level may reflect dolomitization of calcite that involves replacement of half the $\mathrm{Ca}^{2+}$ ions by $\mathrm{Mg}^{2+}$, thereby resulting in removal of magnesium and addition of calcium to interstitial water.

Alkalinity values as high as $40 \mathrm{meq} / \mathrm{L}$ are found near the base of Hole U1391C. If the alkalinity is due to dissolved carbonate, this high value may be related to in situ water-solid equilibrium with the dolomite layer found at the base of the hole (see "Lithostratigraphy"). Correspondingly, high carbonate concentrations would enable the in situ precipitation of dolomite from solution.

The organic geochemistry analysis shows similar trends and values at Sites U1385 and U1391. The $\mathrm{CaCO}_{3}$ values observed at this site is comparable to $\mathrm{CaCO}_{3}$ values at Site U1385, albeit with a greater range at Site U1391. Both sites exhibit a strong posi- 
tive correlation between total organic carbon and C/ $\mathrm{N}$ ratios; Site U1391 has a greater organic contribution from terrestrial matter compared to Site U1385, which can be explained by its closer proximity to land.

\section{Downhole measurements}

\section{Logging operations}

After the last core from Hole U1391C arrived on deck, the hole was prepared for logging. Following a wiper trip, the hole was flushed with sepiolite mud and displaced with $248 \mathrm{bbl}$ of barite-weighted heavy mud (10.5 ppg). The pipe was set at 98.9 mbsf. Two tool strings were deployed in Hole U1391C, the triple combo and FMS-sonic (Fig. F34; see also "Downhole measurements" and Table T6 in the "Methods" chapter [Expedition 339 Scientists, 2013b] for tool acronym definitions).

The triple combo tool string started downhole at 0335 h on 15 January 2012. The Hostile Environment Natural Gamma Ray Sonde (HNGS), High-Resolution Laterolog Array (HRLA), and Hostile Environment Litho-Density Sonde (HLDS) were included. The Accelerator Porosity Sonde was omitted because it allowed the HNGS to be placed at the bottom of the tool string to record to the base of the hole. The tool string reached the base of the hole at $668 \mathrm{mbsf}$, and the main pass was logged up to seafloor. FMSsonic tool string rig-up started at $0920 \mathrm{~h}$, and the tool string also reached close to the bottom of the hole at 666 mbsf. The Pass 1 uplog extended to the seafloor, but bridged sections were noted from 317 to 324 and 330 to 334 mbsf. The hole was closing up, so Pass 2 was run up from 314 mbsf.

Maximum ship heave was generally 1 to $1.5 \mathrm{~m}$ maximum peak-to-peak, but reached $2 \mathrm{~m}$ at times. The tide was high during the triple combo run $(+0.7$ to $+1.2 \mathrm{~m})$ and rising during the FMS-sonic run ( -0.8 to $+0.7 \mathrm{~m}$ ) (Fig. F35). The sediments were PliocenePleistocene nannofossil muds and silty muds (see "Lithostratigraphy"). The wireline heave compensator was used to counter ship heave during logging.

\section{Log data quality}

In Hole U1391C, the borehole wall was very rugose, with many narrow washouts often exceeding 18 inches wide, reducing log data quality (Fig. F36). Some caves were found that were generally associated with low values in all the logs, for example, a large washout from 310 to 320 mbsf. Numerous 1-3 $\mathrm{m}$ thick narrow bridged sections with diameters $<6-8$ inches (bit size $=9.875$ inches) were also found and were mainly concentrated in the middle section of the hole, from 245 to 390 mbsf. Of the all the logs, resistivity and sonic velocity were the least sensitive to variable hole diameter, although some reduction in values in the larger washouts is evident. The NGR $\log$ anticorrelates strongly with the caliper log. Density was highly affected, giving density values close to water density in washouts (Fig. F36). The photoelectric effect log gave anomalously high values below 390 mbsf, especially at washouts, because of the barite-weighted mud. FMS resistivity images were also dominated by poor contact with the borehole wall in the wide areas, although some intervals of good images are present.

\section{Logging units}

The baseline values of the Hole U1391C downhole logs change gradually downhole, with no major steps in the base levels. The entire logged interval was thus assigned to one logging unit (Fig. F36). At the scale of this unit, the NGR signal ranges on average from 30 to 65 gAPI, with peak values reaching 85 gAPI. The signal shows moderately high amplitude variability on a several-meter to submeter scale, and given the sedimentological context (see "Lithostratigraphy"), is primarily tracking clay content. This interpretation is supported by close correlation of the potassium and thorium logs (Fig. F37). Uranium generally contributes a relatively minor component to the total NGR signal and generally behaves as an independent constituent compared to potassium and thorium because it is not chemically combined in the main rock-forming minerals. The sonic velocity log increases downhole (Fig. F36), reflecting sediment compaction with depth, and generally co-varies with the NGR log. The logging unit is divided into two subunits, mostly on the basis of a relative absence of high NGR values below 562 mbsf and a small step down in the density, resistivity, and sonic velocity logs at this depth (Figs. F36, F37).

\section{Logging Subunit 1A: base of drill pipe to 562 mbsf}

Logging Subunit $1 \mathrm{~A}$ is characterized by medium-amplitude alternations in bulk density, NGR (and its uranium, thorium, and potassium components), density, and sonic velocity values (Fig. F36). Several orders of cycles are observed in the NGR curves, varying from one to several tens of meters in thickness (Fig. F37). Potassium and thorium concentrations co-vary closely, suggesting that clay content controls these logs. The uranium concentrations correlate to potassium and thorium at some depths or vary independently at others. As expected from downhole compaction, the density and sonic velocity logs have an increasing downhole trend and are 
generally well correlated. These logs also correlate well with the resistivity curve at a medium scale (several tens of meters). Logging Subunit $1 \mathrm{~A}$ at Site U1391 resembles logging Subunit 1A observed at Sites U1389 and U1390 (see "Downhole measurements" in the "Site U1389" chapter [Expedition 339 Scientists, 2013e]).

\section{Logging Subunit 1B: 562-668 mbsf}

Subunit $1 \mathrm{~B}$ is distinguished from the subunit above by the presence of lower NGR values (Figs. F36, F37). In particular, two intervals with low NGR values are observed from 562 to 582 and 593 to $605 \mathrm{mbsf}$. These intervals suggest the presence of two severalmeter thick sandy intervals that seem to correspond with intervals of low core recovery. A thin layer of high resistivity, high density (reaching $2.52 \mathrm{~g} / \mathrm{cm}^{3}$ ), high velocity, and low NGR values is observed at 631 mbsf (Fig. F36). This high-resistivity horizon is caused by a well-consolidated dolomite mudstone identified in Core 339-U1391C-29R (see "Lithostratigraphy").

\section{Heat flow}

Ten advanced piston corer temperature tool (APCT3) downhole temperature measurements in Holes $\mathrm{U} 1391 \mathrm{~A}$ and $\mathrm{U} 1391 \mathrm{~B}$ ranged from $11.8^{\circ} \mathrm{C}$ at 32.0 mbsf to $13.3^{\circ} \mathrm{C}$ at 145.95 mbsf (Fig. F38; Table T18), giving a geothermal gradient of $14.2^{\circ} \mathrm{C} / \mathrm{km}$ (Fig. F39). The measurements increase linearly with depth, and the trend line intersects the seafloor at $11.35^{\circ} \mathrm{C}$. Some scatter and minor differences between the two holes is evident. These differences are probably caused by (1) uncertainty in fitting to the APCT-3 temperature equilibration curves to obtain the formation temperature and (2) lateral heterogeneity in heat flow leading to small temperature differences between the holes. Readings at shallower depths have more uncertainty because the APC barrel has more freedom of movement in the hole where the sediment is soft. Unlike at previous sites, the bottom water temperature was repeatably constrained from the APCT-3 temperature profiles (Fig. F38), both while the APC was held at the mudline $\left(\sim 11.6^{\circ} \mathrm{C}\right)$ and the minimum temperature in the profiles $\left(\sim 11.5^{\circ} \mathrm{C}\right)$, similar to, but a little higher than the estimate from the intersection of the linear temperature trend with the seafloor.

Thermal conductivity under in situ conditions was estimated from laboratory-determined thermal conductivity using the method of Hyndman et al. (1974) (see "Physical properties" in the "Methods" chapter [Expedition 339 Scientists, 2013b]). The calculated in situ values average $1.2 \%$ below the measured laboratory values. Thermal resistance was then calculated by integrating the inverse of in situ thermal conductivity over depth (Fig. F39). A heat flow of $17.5 \mathrm{~mW} / \mathrm{m}^{2}$ was obtained from the linear fit between temperature and thermal resistance (Pribnow et al., 2000). This value is very low compared to heat flow values for the nearby Marques de Pombal escarpment (Grevemeyer et al., 2009).

\section{Stratigraphic correlation}

The meters composite depth (mcd) scale for Site U1391 was based on correlation of magnetic susceptibility and NGR data between Holes U1391AU1391C. Both Holes U1391A and U1391B were cored to APC refusal, which occurred at $\sim 171 \mathrm{mbsf}$ at the base of Cores 339-U1391A-19H and 339-U1391B$18 \mathrm{H}$, and then XCB cored to $\sim 353$ mbsf. Hole U1391C was RCB cored downhole from 340 mbsf, overlapping only the very basal part cored in the other two holes.

The correlation between Holes U1391A and U1391B is relatively straightforward downhole to $169 \mathrm{mcd}$ (base of Core 339-U1391A-16H), except that the correlation of Core 339-U1391A-14H to 339-U1391B$13 \mathrm{H}$ is poor because susceptibility and NGR data lack distinctive features across this connection, which spans $\sim 128-131 \mathrm{mcd}$ (Fig. F40). From $169 \mathrm{mcd}$ downhole to $\sim 310 \mathrm{mcd}$, susceptibility is very low and has few features that can be correlated with confidence. Hence, NGR data are the primary constraint through this interval and generally provide distinct anomalies that can be correlated to within $\sim 20 \mathrm{~cm}$. An exception to this occurs from $\sim 250$ to $262 \mathrm{mcd}$, where the NGR signal is relatively constant, making correlation between holes very uncertain.

No gaps occur in the stratigraphic section until the base of Cores 339-U1391A-19H and 339-U1391B$18 \mathrm{H}$, where both cores were unable to penetrate deeper than 171 mbsf (i.e., the APC refusal depth), corresponding to $\sim 196 \mathrm{mcd}$. Thus, a small gap occurs at this depth. Another small gap occurs at $243 \mathrm{mcd}$ (between Cores 339-U1391B-23X and 24X) that is not filled by core from Hole U1391A because Core 339-U1391A-24X had no recovery. Other very small gaps (less than $\sim 30 \mathrm{~cm}$ ) may occur at approximately 272, 283, 292, and 336 mcd.

NGR and susceptibility data for Cores 339-U1391C2R and 3R correlate well with Cores 339-U1391A$38 \mathrm{X}$ and 339-U1391B-37X and 38X and those of Core 339-U1391C-4R with the base of 339-U1391B$38 \mathrm{X}$. Hence, the base of Core 339-U1391C-4R marks the base of the multi-cored interval.

Overall, the three holes cored at Site U1391 provide enough material to produce a composite strati- 
graphic section that is complete, with few or no gaps from seafloor downhole to the base of Core 339$\mathrm{U} 1391 \mathrm{C}-4 \mathrm{R}$ at $417.66 \mathrm{mcd}$ (358 mbsf). The section below this depth is cored only in Hole U1391C downhole to a total depth of $671.5 \mathrm{mbsf}$, with short gaps inevitably occurring between cores and larger gaps occurring wherever core recovery is low.

The offsets and composite depths are listed in Table T19. A growth factor of 1.144 is calculated by linear regression for the multicored interval in Holes U1391A and U1391B, indicating a 14.4\% expansion of mcd values relative to mbsf values (Fig. F41). Because of the very linear nature of the expansion, the mcd scale can readily be compressed by dividing by 1.144 to produce a modified depth scale $\left(\mathrm{mbsf}^{\star}\right)$ that corresponds more closely to true coring depths while retaining the between-hole correlations. This is illustrated for NGR data in Holes U1391A-U1391C in Figure F42. For the single-cored interval, the relative gaps between cores can be estimated by using a similar growth factor (Table T19).

Splice tie points for the composite section are given in Table T20. Spliced records are provided for susceptibility (Table T21) and NGR (Table T22).

\section{References}

Alves, T.M., Gawthorpe, R.L., Hunt, D., and Monteiro, J.H., 2000. Tertiary evolution of the São Vicente and Setúbal submarine canyons, southwest Portugal: insights from seismic stratigraphy. Cienc. Terra (UNL), 14:243-256. http://hdl.handle.net/10362/4716

Alves, T.M., Gawthorpe, R.L., Hunt, D.W., and Monteiro, J.H., 2003. Cenozoic tectono-sedimentary evolution of the western Iberian margin. Mar. Geol., 195(1-4):75108. doi:10.1016/S0025-3227(02)00683-7

Bender, V.B., Hanebuth, T.J.J., and Baumann, K.H., 2010. Detrital input, marine productivity, deep water currents, and sea level alternatively influencing sedimentation on the Galician continental margin over the past 30 ka BP. Geo-Temas, 11:19-20

Berggren, W.A, Hilgen, F.J., Langereis, C.G., Kent, D.V., Obradovich, J.D., Raffi, I., Raymo, M.E., and Shackelton, N.J., 1995. Late Neogene chronology: new perspectives in high-resolution stratigraphy. Geol. Soc. Am. Bull., 107(11):1272-1287. doi:10.1130/00167606(1995)107<1272:LNCNPI>2.3.CO;2

Blum, P., 1997. Physical properties handbook: a guide to the shipboard measurement of physical properties of deep-sea cores. ODP Tech. Note, 26. doi:10.2973/ odp.tn.26.1997

Egbert, G.D., and Erofeeva, S.Y., 2002. Efficient inverse modeling of barotropic ocean tides. J. Atmos. Oceanic Technol., 19(2):183-204. doi:10.1175/15200426(2002)019<0183:EIMOBO>2.0.CO;2

Emerson, S., and Hedges, J.I., 1988. Processes controlling the organic carbon content of open ocean sediments.
Paleoceanography, 3(5):621-634. doi:10.1029/ PA003i005p00621

Ercilla, G., Casas, D., Estrada, F., Vázquez, J.T., Iglesias, J., García, M., Gómez, M., Acosta, J., Gallart, J., MaestroGonzález, A., and the Marconi Team, 2008. Morphosedimentary features and recent depositional architectural model of the Cantabrian continental margin. Mar. Geol., 247(1-2):61-83 doi:10.1016/j.margeo.2007.08.007

Ercilla, G., Casas, D., Iglesias, J., Vázquez, J.T., Somoza, L., León, R., Medialdea, T., Juan, C., and García, M., 2010. Contourites in the Galicia Bank region (NW Iberian Atlantic). Geo-Temas, 11:33-34.

Ercilla, G., Casas, D., Somoza, L., Vázquez, J.T., Iglesias, J., García-Gil, S., Medialdea, T., León, R., Estrada, F., and the ERGAP Project Cruise Teams, 2009. Cartografiando la dinámica sedimentaria de la región del Banco de Galicia. Simp. Margen Ibérico Atlántico, MIA09:201-204. http://digital.csic.es/bitstream/10261/20971/1/ MIA09_BANCO.pdf

Ercilla, G., Casas, D., Vázquez, J.T., Iglesias, J., Somoza, L., Juan, C., Medialdea, T., León, R., Estrada, F., García-Gil, S., Farran, M., Bohoyo, F., Gracía, M., Maestro, A., and the ERGAP Project Cruise Teams, 2011. Imaging the recent sediment dynamics of the Galicia Bank region (Atlantic, NW Iberian Peninsula). Mar. Geophys. Res., 32(1-2):99-126. doi:10.1007/s11001-011-9129-x

Expedition 339 Scientists, 2013a. Expedition 339 summary. In Stow, D.A.V., Hernández-Molina, F.J., Alvarez Zarikian, C.A., and the Expedition 339 Scientists, Proc. IODP, 339: Tokyo (Integrated Ocean Drilling Program Management International, Inc.). doi:10.2204/ iodp.proc.339.101.2013

Expedition 339 Scientists, 2013b. Methods. In Stow, D.A.V., Hernández-Molina, F.J., Alvarez Zarikian, C.A., and the Expedition 339 Scientists, Proc. IODP, 339: Tokyo (Integrated Ocean Drilling Program Management International, Inc.). doi:10.2204/iodp.proc.339.102.2013

Expedition 339 Scientists, 2013c. Site U1385. In Stow, D.A.V., Hernández-Molina, F.J., Alvarez Zarikian, C.A., and the Expedition 339 Scientists, Proc. IODP, 339: Tokyo (Integrated Ocean Drilling Program Management International, Inc.). doi:10.2204/ iodp.proc.339.103.2013

Expedition 339 Scientists, 2013d. Site U1387. In Stow, D.A.V., Hernández-Molina, F.J., Alvarez Zarikian, C.A., and the Expedition 339 Scientists, Proc. IODP, 339: Tokyo (Integrated Ocean Drilling Program Management International, Inc.). doi:10.2204/ iodp.proc.339.105.2013

Expedition 339 Scientists, 2013e. Site U1389. In Stow, D.A.V., Hernández-Molina, F.J., Alvarez Zarikian, C.A., and the Expedition 339 Scientists, Proc. IODP, 339: Tokyo (Integrated Ocean Drilling Program Management International, Inc.). doi:10.2204/ iodp.proc.339.107.2013

Expedition 339 Scientists, 2013f. Site U1390. In Stow, D.A.V., Hernández-Molina, F.J., Alvarez Zarikian, C.A., and the Expedition 339 Scientists, Proc. IODP, 339: Tokyo (Integrated Ocean Drilling Program Management 
International, Inc.). doi:10.2204/

iodp.proc.339.108.2013

Flores, J.-A., Colmenero-Hidalgo, E., Mejía-Molina, A.E., Baumann, K.-H., Hendericks, J., Larsson, K., Prabhu, C.N., Sierro, F.J., and Rodrigues, T., 2010. Distribution of large Emiliania huxleyi in the central and northeast Atlantic as a tracer of surface ocean dynamics during the last 25,000 years. Mar. Micropaleontol., 76(3-4):5366. doi:10.1016/j.marmicro.2010.05.001

Grevemeyer, I., Kaul, N., and Kopf, A., 2009. Heat flow anomalies in the Gulf of Cadiz and off Cape San Vincente, Portugal. Mar. Pet. Geol., 26(6):795-804. doi:10.1016/j.marpetgeo.2008.08.006

Hayward, B.W., 2002. Late Pliocene to middle Pleistocene extinctions of deep-sea benthic foraminifera ("Stilostomella extinction") in the southwest Pacific. J. Foraminiferal Res., 32(3):274-307. doi:10.2113/32.3.274

Hernández-Molina, F.J., Llave, E., Somoza, L., FernándezPuga, M.C., Maestro, A., León, R., Medialdea, T., Barnolas, A., García, M., Díaz del Río, V., Fernández-Salas, L.M., Vázquez, J.T., Lobo, F., Alveirinho Dias, J.M., Rodero, J., and Gardner, J., 2003. Looking for clues to paleoceanographic imprints: a diagnosis of the Gulf of Cádiz contourite depositional systems. Geology, 31(1):19-22. doi:10.1130/00917613(2003)031<0019:LFCTPI>2.0.CO;2

Hernández-Molina, F.J., Nombela, M.A., Van Rooij, D., Roson, G., Ercilla, G., Urgorri, V., Llave, E., Francés, G., De Mol, L., Estrada, F., León, R., Mena, A., Pérez Arlucea, M., Alejo I., Jane, G., and VanReusel, A., 2009. The Ortegal spur contourite depositional system (Bay of Biscay): the implications of the Mediterranean Outflow Waters in sedimentary processes and cold-water coral ecosystems. Simp. Margen Ibérico Atlántico, MIA09:281-284. http://digital.csic.es/bitstream/10261/20974/1/ MIA09_ORTEGAL.pdf

Hilgen, F.J., 1991. Extension of the astronomically calibrated (polarity) time scale to the Miocene/Pliocene boundary. Earth Planet. Sci. Lett., 107(2):349-368. doi:10.1016/0012-821X(91)90082-S

Hyndman, R.D., Erickson, A.J., and Von Herzen, R.P., 1974. Geothermal measurements on DSDP Leg 26. In Davies, T.A., Luyendyk, B.P., et al., Init. Repts. DSDP, 26: Washington, DC (U.S. Govt. Printing Office), 451-463. doi:10.2973/dsdp.proc.26.113.1974

Iglesias, J., 2009. Sedimentation on the Cantabrian continental margin from late Oligocene to Quaternary [Ph.D. thesis]. Univ. Vigo, Spain.

Iorga, M.C., and Lozier, M.S., 1999. Signatures of the Mediterranean Outflow from a North Atlantic climatology1. Salinity and density fields. J. Geophys. Res., [Oceans], 104(C11):25985-26029. doi:10.1029/1999JC900115

Kaiho, K., 1999. Effect of organic carbon flux and dissolved oxygen on the benthic foraminiferal oxygen index (BFOI). Mar. Micropaleontol., 37(1):67-76. doi:10.1016/ S0377-8398(99)00008-0

Kawagata, S., Hayward, B.W., Grenfell, H.R., and Sabaa, A., 2005. Mid-Pleistocene extinction of deep-sea foraminifera in the North Atlantic Gateway (ODP Sites 980 and
982). Palaeogeogr., Palaeoclimatol., Palaeoecol., 221(3-

4):267-291. doi:10.1016/j.palaeo.2005.03.001

Leckie, R.M., and Olson, H.C., 2003. Foraminifera as proxies of sea-level change on siliciclastic margins. In Olson, H.C., and Leckie, R.M. (Eds.), Micropaleontologic Proxies of Sea-Level Change and Stratigraphic Discontinuities. Spec. Publ._SEPM (Soc. Sediment. Geol.), 75:5-19.

Llave, E., Hernández-Molina, F.J., Somoza, L., Stow, D.A.V., and Díaz Del Río, V., 2007. Quaternary evolution of the contourite depositional system in the Gulf of Cádiz. Geol. Soc. Spec. Publ., 276:49-79. doi:10.1144/ GSL.SP.2007.276.01.03

Llave, E., Matias, H., Hernández-Molina, F.J., Ercilla, G., Stow, D.A.V., and Medialdea, T., 2011. Pliocene-Quaternary contourites along the northern Gulf of Cadiz margin: sedimentary stacking pattern and regional distribution. Geo-Mar. Lett., 31(5-6):377-390. doi:10.1007/s00367-011-0241-3

Lourens, L., Hilgen, F., Shackleton, N.J., Laskar, J., and Wilson, D., 2004. The Neogene period. In Gradstein, F.M., Ogg, J.G., and Smith, A. (Eds.), A Geologic Time Scale 2004: Cambridge (Cambridge Univ. Press), 409-440.

Mena, A., Francés, G., Pérez Arlucea, M., Hanebuth, T.J.J., and Nombela, M.A., 2010. Sedimentary evolution of the Galicia inner basin during the last 70 k.y. Geo-Temas, 11:125-126.

Meyers, P.A., 1997. Organic geochemical proxies of paleoceanographic, paleolimnologic, and paleoclimatic processes. Org. Geochem., 27(5-6):213-250. doi:10.1016/ S0146-6380(97)00049-1

Murray, J.W., 2006. Ecology and Applications of Benthic Foraminifera: Cambridge (Cambridge Univ. Press).

Pereira, R., and Alves, T.M., 2011. Margin segmentation prior to continental break-up: a seismic-stratigraphic record of multiphased rifting in the North Atlantic (southwest Iberia). Tectonophysics, 505(1-4):17-34. doi:10.1016/j.tecto.2011.03.011

Pribnow, D., Kinoshita, M., and Stein, C., 2000. Thermal Data Collection and Heat Flow Recalculations for Ocean Drilling Program Legs 101-180: Hanover, Germany (Inst. Joint Geosci. Res., Inst. Geowiss. Gemeinschaftsauf. [GGA]). http://www-odp.tamu.edu/publications/ heatflow/ODPReprt.pdf

Raffi, I., Backman, J., Fornaciari, E., Pälike, H., Rio, D., Lourens, L., and Hilgen, F., 2006. A review of calcareous nannofossil astrobiochronology encompassing the past 25 million years. Quat. Sci. Rev., 25(23-24):3113-3137. doi:10.1016/j.quascirev.2006.07.007

Raffi, I., Backman, J., Rio, D., and Shackleton, N.J., 1993. Plio-Pleistocene nannofossil biostratigraphy and calibration to oxygen isotope stratigraphies from Deep Sea Drilling Project Site 607 and Ocean Drilling Program Site 677. Paleoceanography, 8(3):387-408. doi:10.1029/ 93PA00755

Raymo, M.E., Ruddiman, W.F., Backman, J., Clement, B.M., and Martinson, D.G., 1989. Late Pliocene variation in Northern Hemisphere ice sheets and North Atlantic deep water circulation. Paleoceanography, 4(4):413-446. doi:10.1029/PA004i004p00413 
Schönfeld, J., 1997. The impact of the Mediterranean Outflow Water (MOW) on benthic foraminiferal assemblages and surface sediments at the southern Portuguese continental margin. Mar. Micropaleontol., 29(3-4):211236. doi:10.1016/S0377-8398(96)00050-3

Schönfeld, J., 2002. Recent benthic foraminiferal assemblages in deep high-energy environments from the Gulf of Cádiz (Spain). Mar. Micropaleontol., 44(3-4):141-162. doi:10.1016/S0377-8398(01)00039-1

Schönfeld, J., and Zahn, R., 2000. Late glacial to Holocene history of the Mediterranean Outflow. Evidence from benthic foraminiferal assemblages and stable isotopes at the Portuguese margin. Palaeogeogr., Palaeoclimatol., Palaeoecol., 159(1-2):85-111. doi:10.1016/S00310182(00)00035-3

Serra, N., Ambar, I., and Boutov, D., 2010. Surface expression of Mediterranean water dipoles and their contribution to the shelf/slope-open ocean exchange. Ocean Sci., 6(1):191-209. doi:10.5194/os-6-191-2010

Sierro, F.J., Hernandez-Almeida, I., Alonso-Garcia, M., and Flores, J.A., 2009. Data report: Pliocene-Pleistocene planktonic foraminifer bioevents at IODP Site U1313. In Channell, J.E.T., Kanamatsu, T., Sato, T., Stein, R., Alvarez Zarikian, C.A., Malone, M.J., and the Expedition 303/306 Scientists, Proc. IODP, 303/306: College Station, TX (Integrated Ocean Drilling Program Management International, Inc.). doi:10.2204/

iodp.proc.303306.205.2009

Stow, D., Hernández-Molina, F.J., Hodell, D., and Alvarez Zarikian, C.A., 2011. Mediterranean outflow: environmental significance of the Mediterranean Outflow Water and its global implications. IODP Sci. Prosp., 339. doi:10.2204/iodp.sp.339.2011

Terrinha, P., Pinheiro, L.M., Henriet, J.-P., Matias, L., Ivanov, M.K., Monteiro, J.H., Akhmetzhanov, A., Volkonskaya, A., Cunha, T., Shaskin, P., and Rovere, M., 2003. Tsunamigenic-seismogenic structures, neotectonics, sedimentary processes, and slope stability on the southwest Portuguese margin. Mar. Geol., 195(1-4):55-73. doi:10.1016/S0025-3227(02)00682-5

Turon, J.-L., Lézine, A.-M., and Denèfle, M., 2003. Landsea correlations for the last glaciation inferred from a pollen and dinocyst record from the Portuguese margin.
Quat. Res., 59(1):88-96. doi:10.1016/S00335894(02)00018-2

van Morkhoven, F.P.C.M., Berggren, W.A., and Edwards, A.S., 1986. Cenozoic Cosmopolitan Deep-Water Benthic Foraminifera. Bull. Cent. Rech. Explor.-Prod. Elf-Aquitaine, 11.

Van Rooij, D., De Mol, B., Huvenne, V., Ivanov, M., and Henriet, J.-P., 2003. Seismic evidence of current-controlled sedimentation in the Belgica mound province, upper Porcupine slope, southwest of Ireland. Mar. Geol., 195(1-4):31-53. doi:10.1016/S0025-3227(02)00681-3

Van Rooij, D., Iglesias, J., Hernández-Molina, F.J., Ercilla, G., Gomez-Ballesteros, M., Casas, D., Llave, E., De Hauwere, A., Garcia-Gil, S., Acosta, J., and Henriet, J.-P., 2010. The Le Danois contourite depositional system: interactions between the Mediterranean Outflow Water and the upper Cantabrian slope (North Iberian margin). Mar. Geol., 274(1-4):1-20 doi:10.1016/j.margeo.2010.03.001

Weaver, P.P.E., and Clement, B.M., 1987. Magnetobiostratigraphy of planktonic foraminiferal datums: Deep Sea Drilling Project Leg 94, North Atlantic. In Ruddiman, W.F., Kidd, R.B., Thomas, E., et al., Init. Repts. DSDP, 94: Washington (U.S. Govt. Printing Office), 815829. doi:10.2973/dsdp.proc.94.120.1987

Wei, W., 1993. Calibration of upper Pliocene-lower Pleistocene nannofossil events with oxygen isotope stratigraphy. Paleoceanography, 8(1):85-99. doi:10.1029/ 92PA02504

Zachariasse, W.J., Zijderveld, J.D.A., Langereis, C.G., Hilgen, F.J., and Verhallen, P.J.J.M., 1989. Early late Pliocene biochronology and surface water temperature variations in the Mediterranean. Mar. Micropaleontol., 14(4):339-355. doi:10.1016/0377-8398(89)90018-2

Zitellini, N., Rovere, M., Terrinha, P., Chierici, F., Matias, L., and the Bigsets Team, 2004. Neogene through Quaternary tectonic reactivation of SW Iberian passive margin. Pure Appl. Geophys., 161(3):565-587. doi:10.1007/ s00024-003-2463-4

Publication: 17 June 2013

MS 339-109 
Figure F1. 3-D sketch showing the plastered drift on the middle slope terrace from the most distal sector of the contourite depositional system of the Gulf of Cádiz and west off Portugal (made by H. Pereira, Escola Secundária de Loulé, using Mirone and iView4D software).

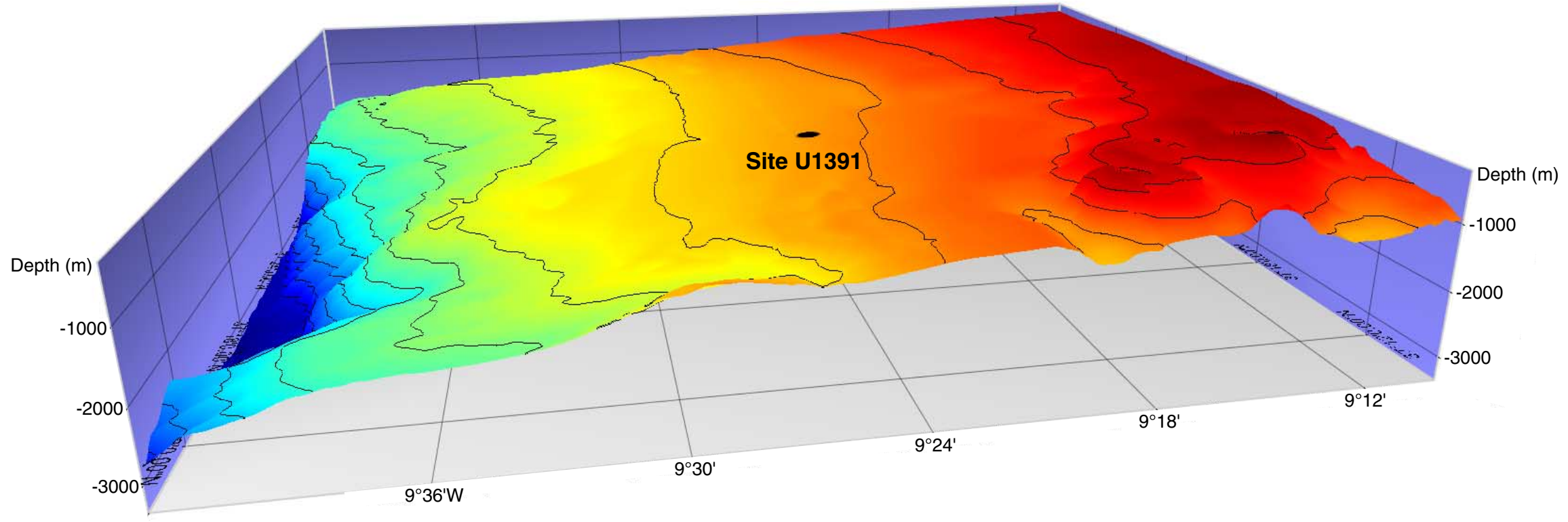


Figure F2. Bathymetric sketch showing the location of Site U1391 $\left(37^{\circ} 21.5322^{\prime} \mathrm{N}, 9^{\circ} 24.6558^{\prime} \mathrm{W}\right)$ on the plastered drift over the middle slope terrace in the Portuguese margin.

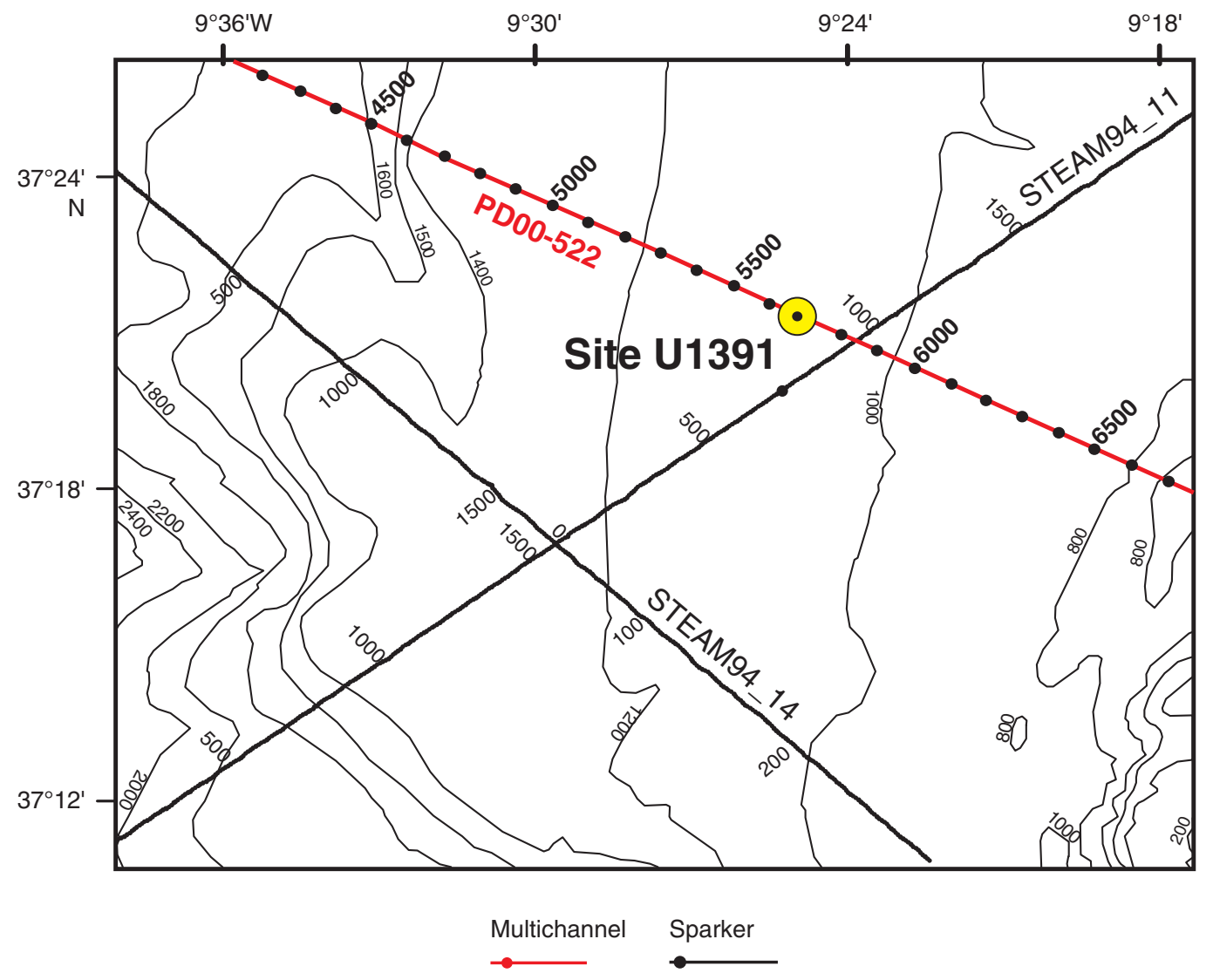


Figure F3. Graphic lithology summary log, Site U1391.

\section{Site U1391}

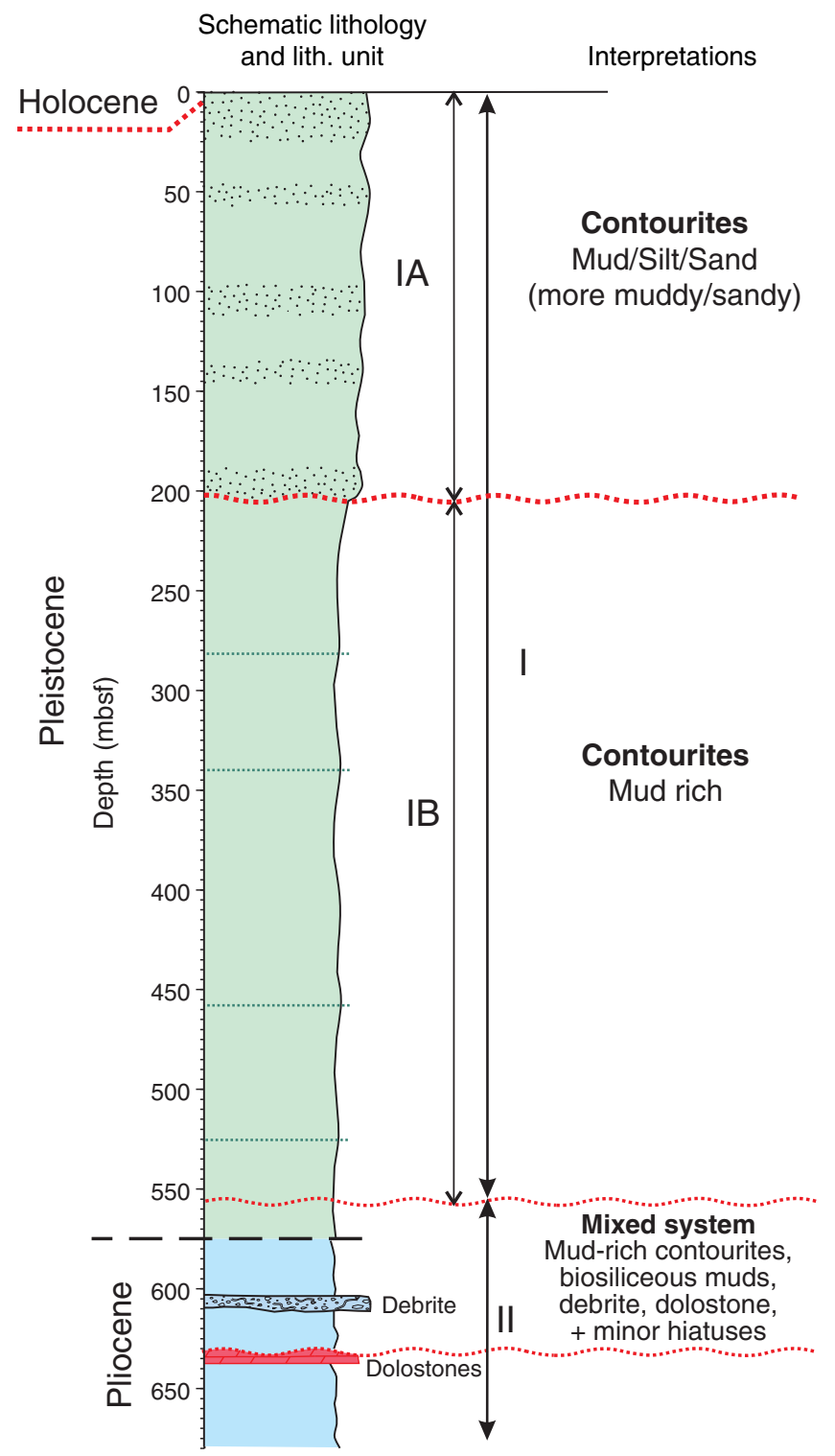


Figure F4. Plots of downhole variations in lithologies, texture and composition for Site U1391.

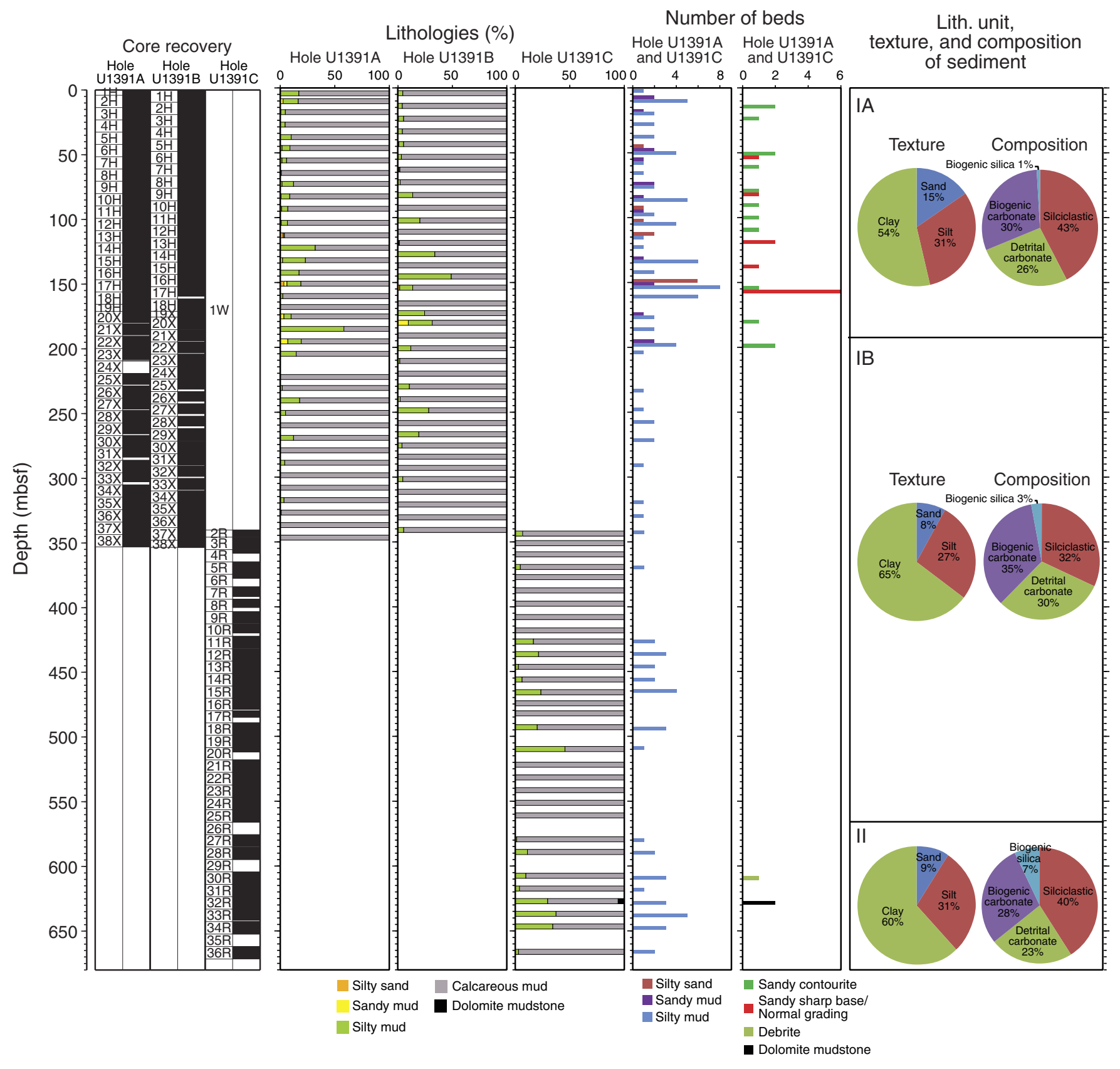




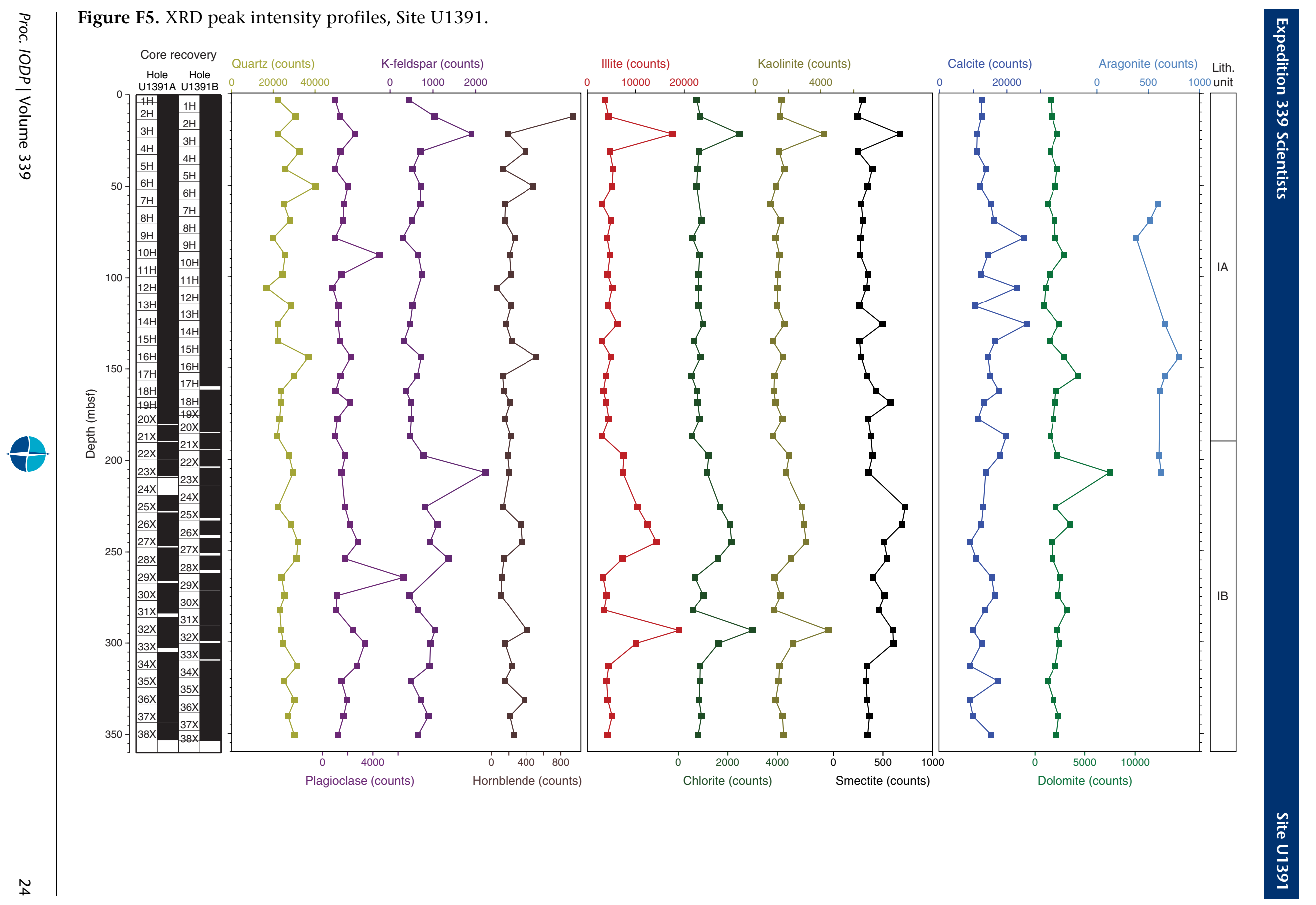


Figure F6. Graphic lithology summaries. A. Hole U1391A. (Continued on next two pages.)

A

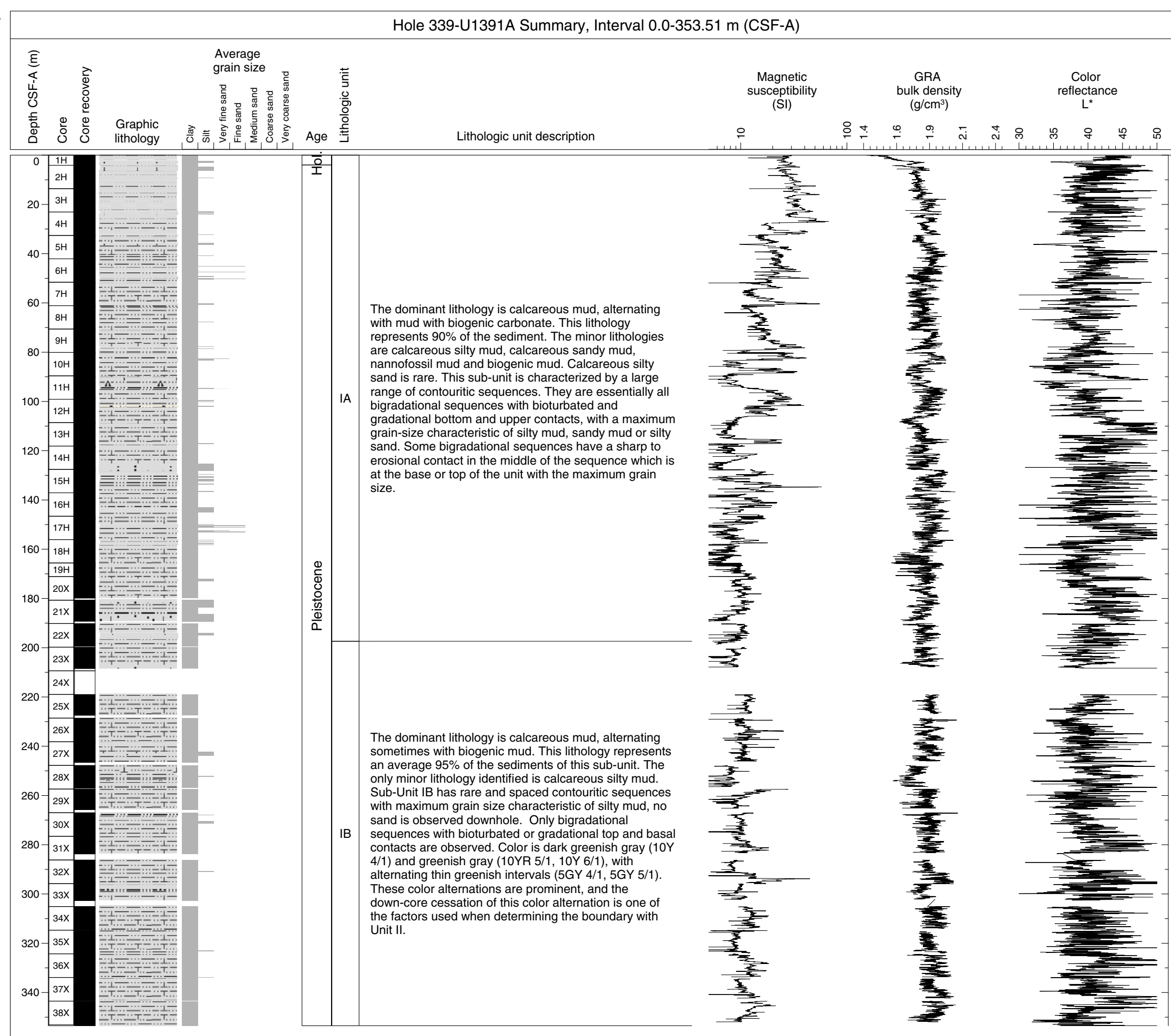


Figure F6 (continued). B. Hole U1391B. (Continued on next page.)

B

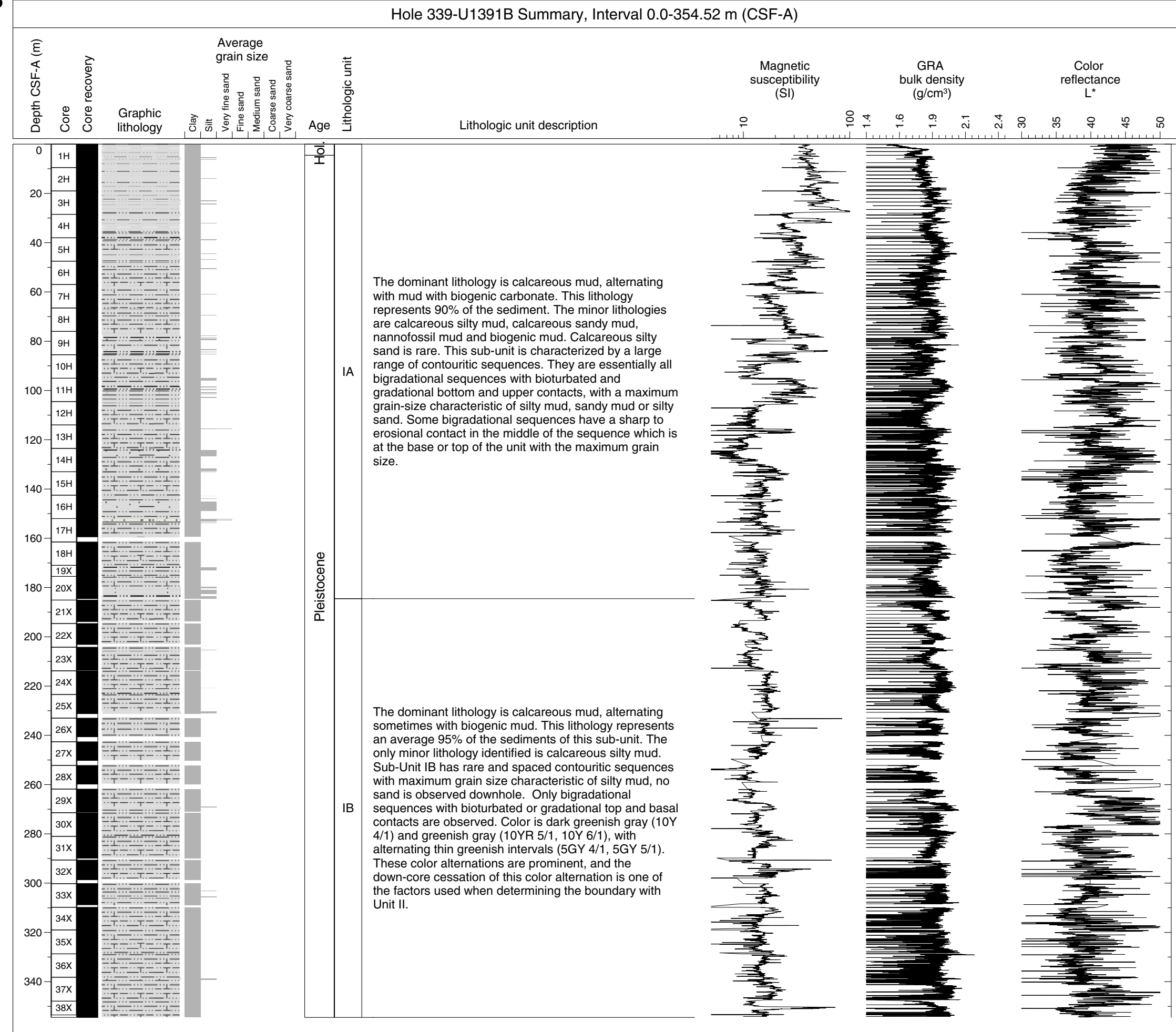


Figure F6 (continued). C. Hole U1391C.

C

Hole 339-U1391C Summary, Interval 0.0-670.98 m (CSF-A)

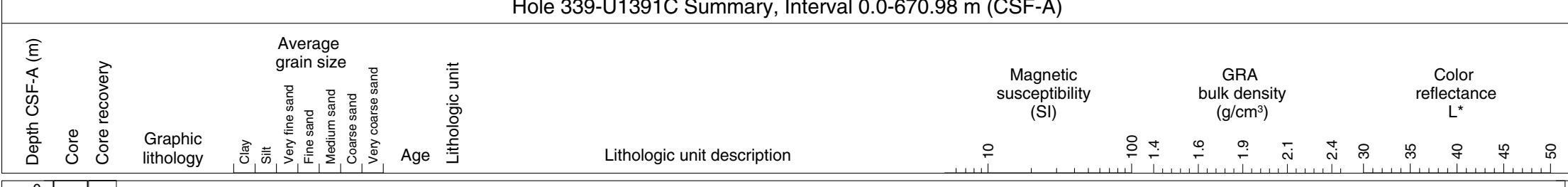

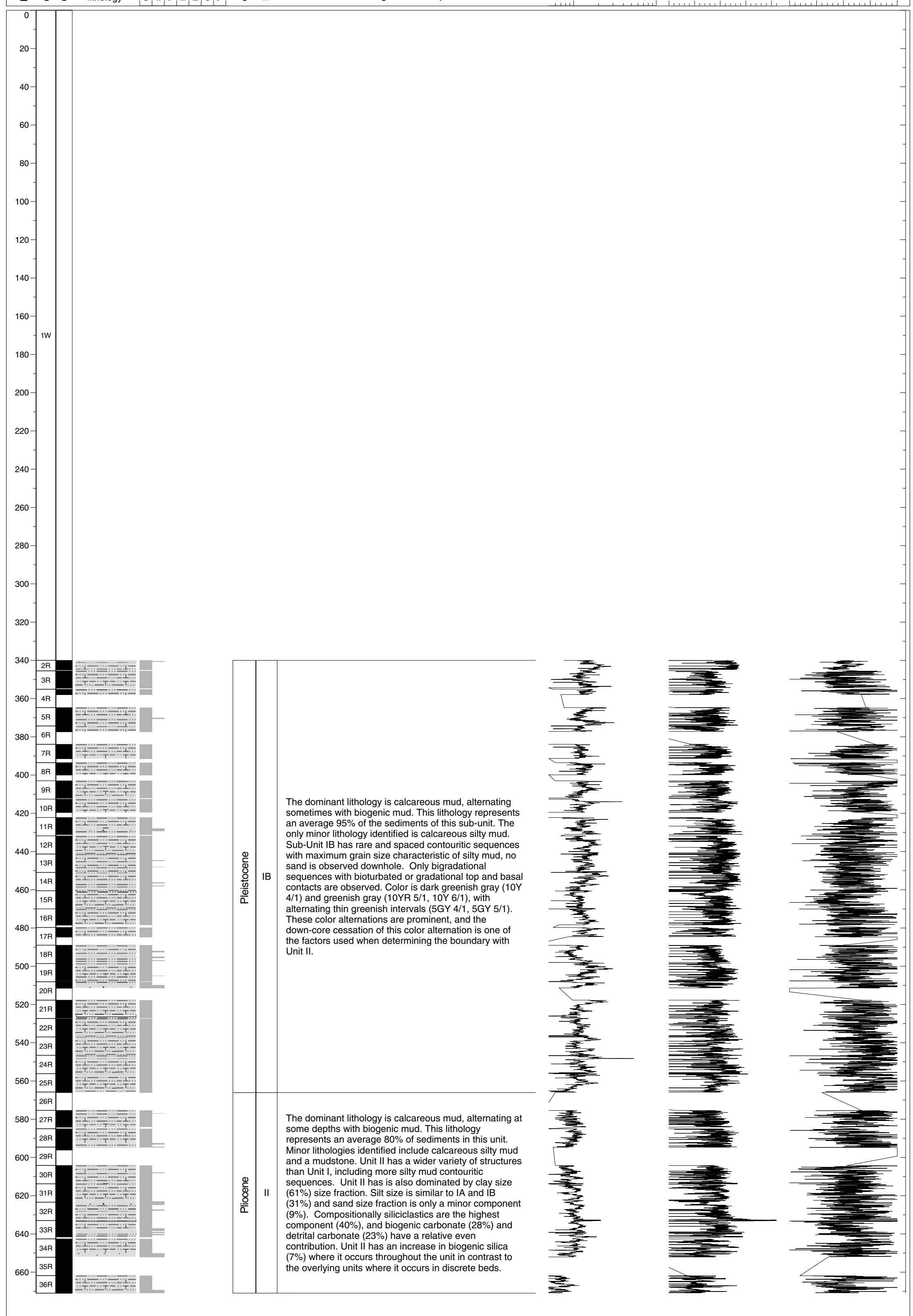



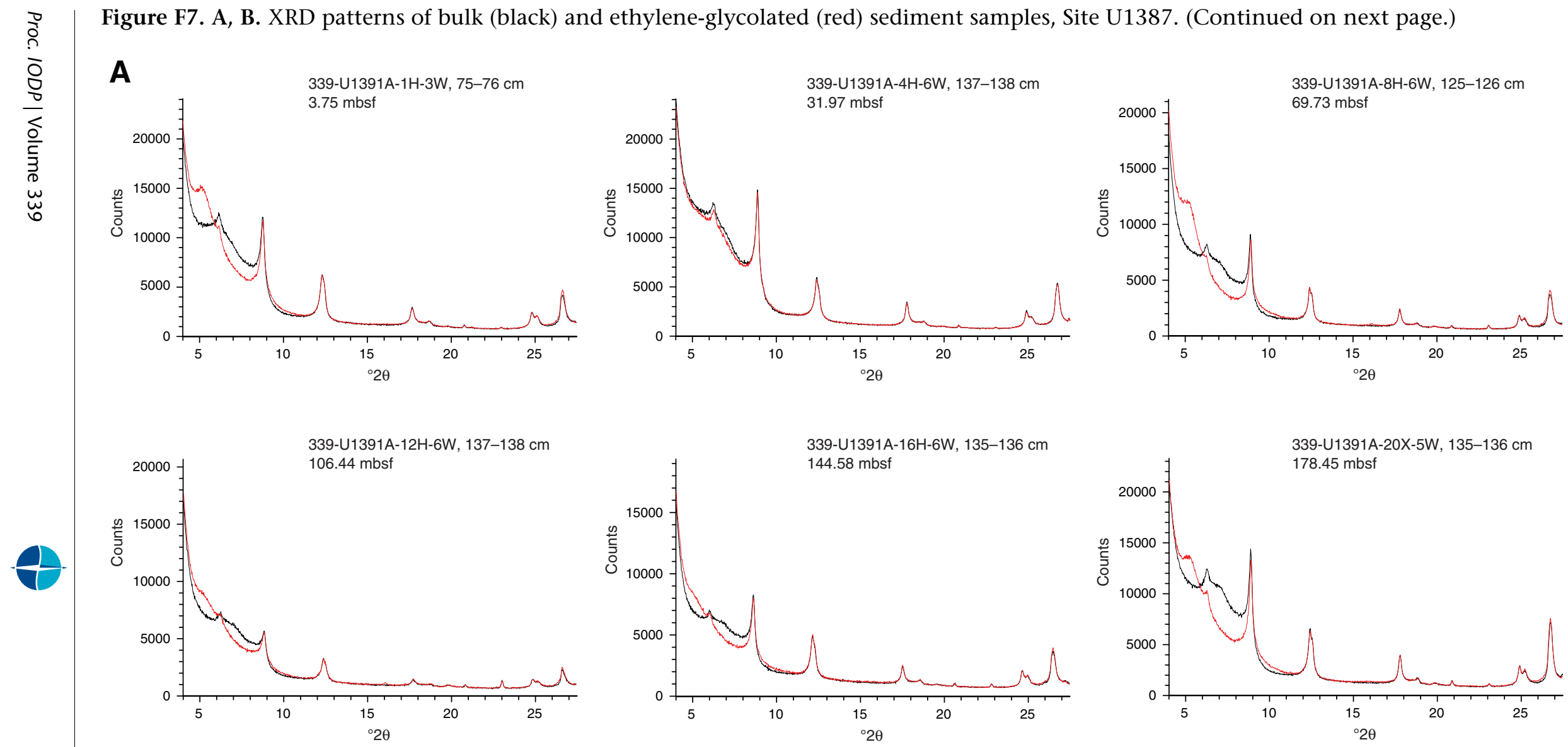

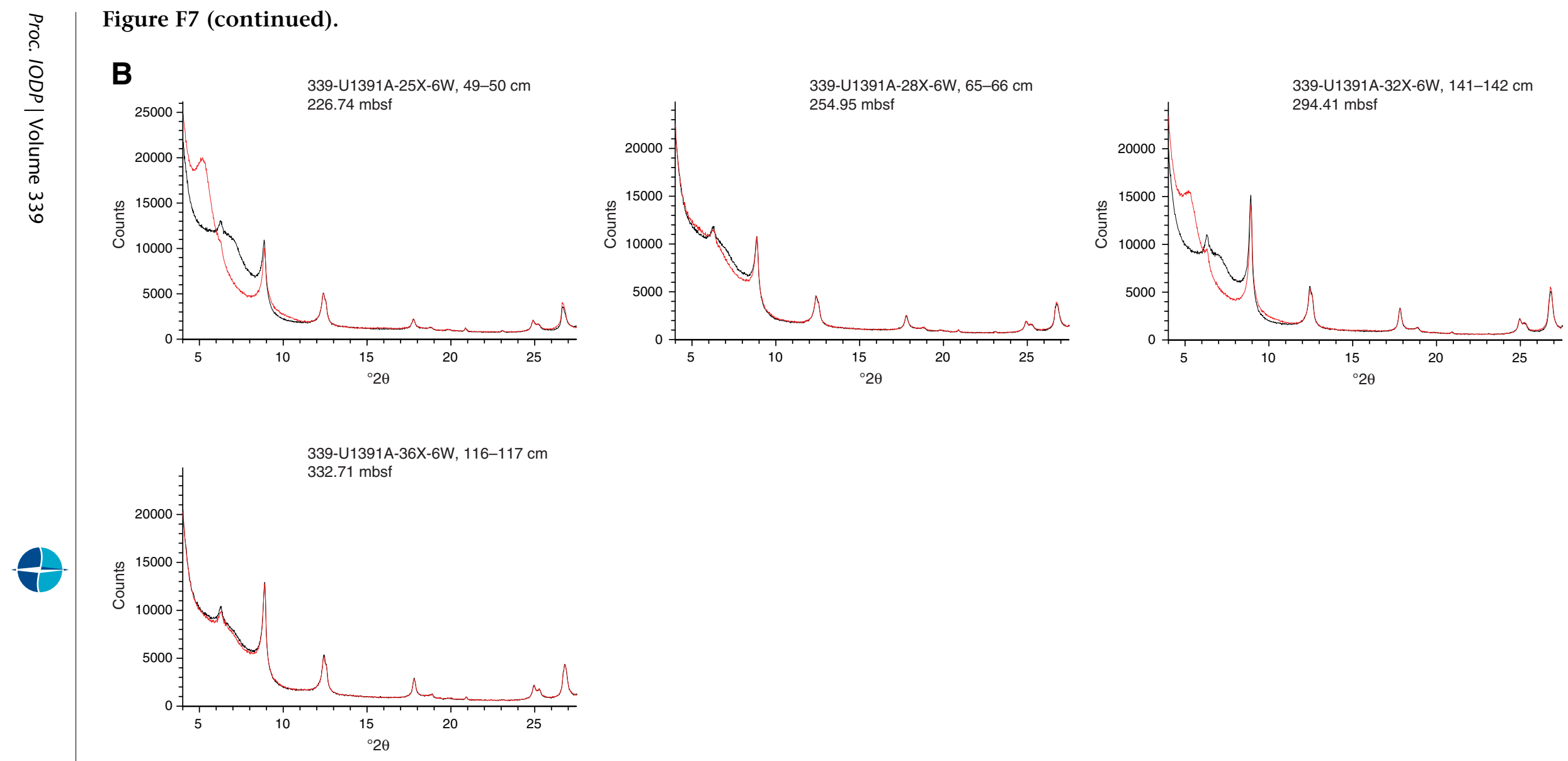
Figure F8. Core image of bi-gradational sequence and internal contact with a foraminifer-rich sand (Section 339-U1391A-6H-6A).

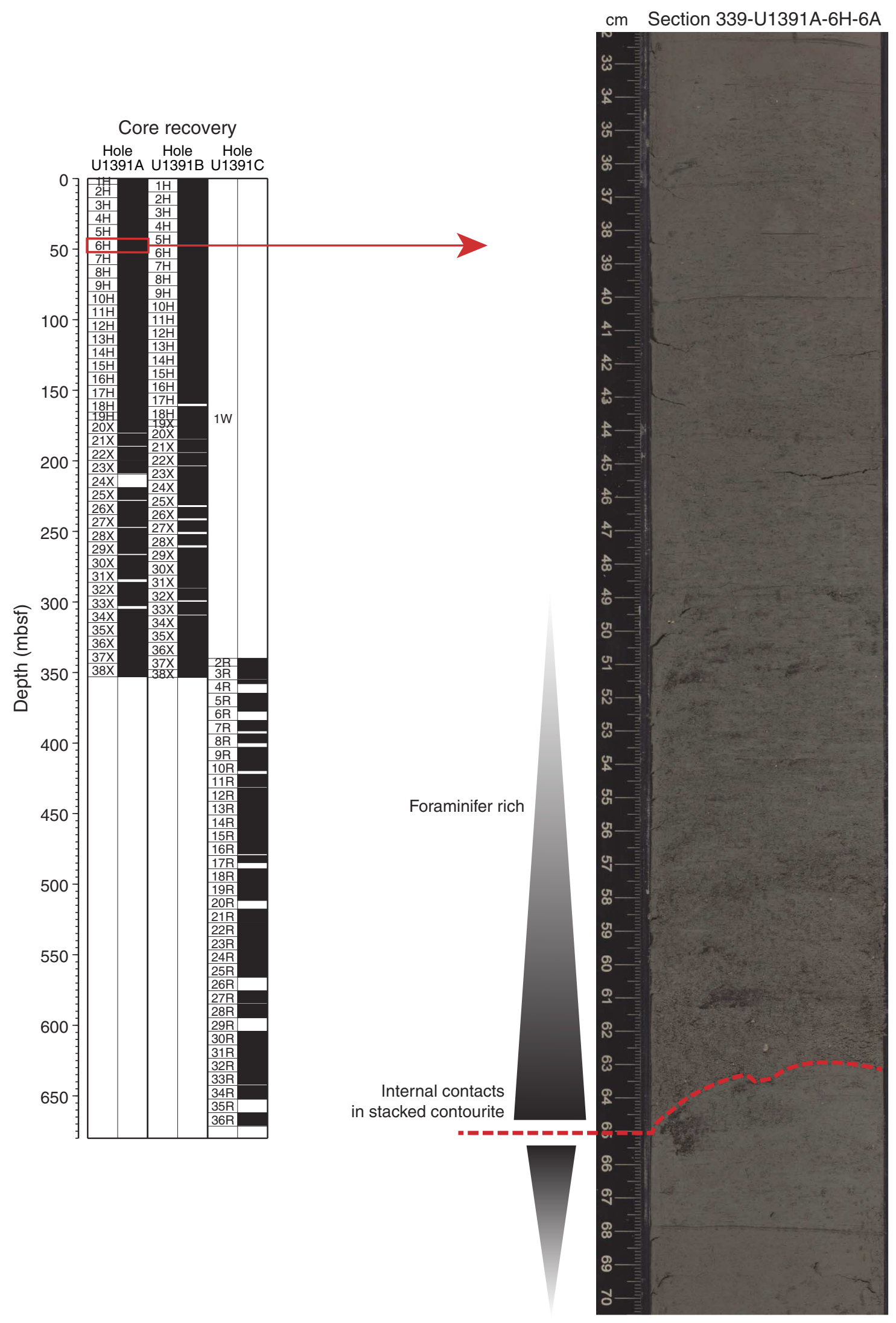


Figure F9. Core image of bi-gradational sequence with sharp internal contact (Section 339-U1391A-9H-6A).

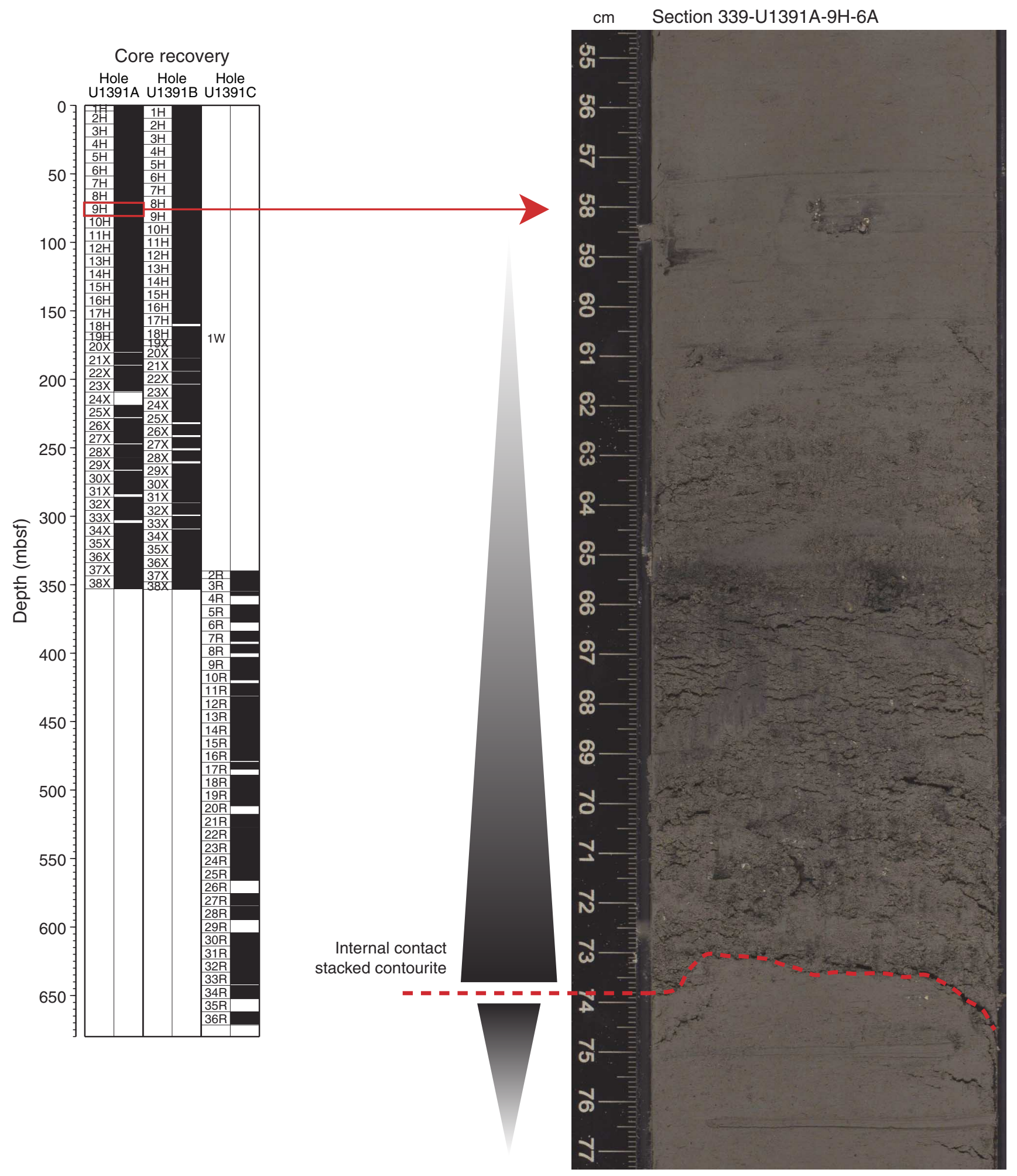


Figure F10. Core image of bi-gradational sequence and sharp internal contact with a foraminifer-rich sand (Section 339-U1391A-6H-4A).

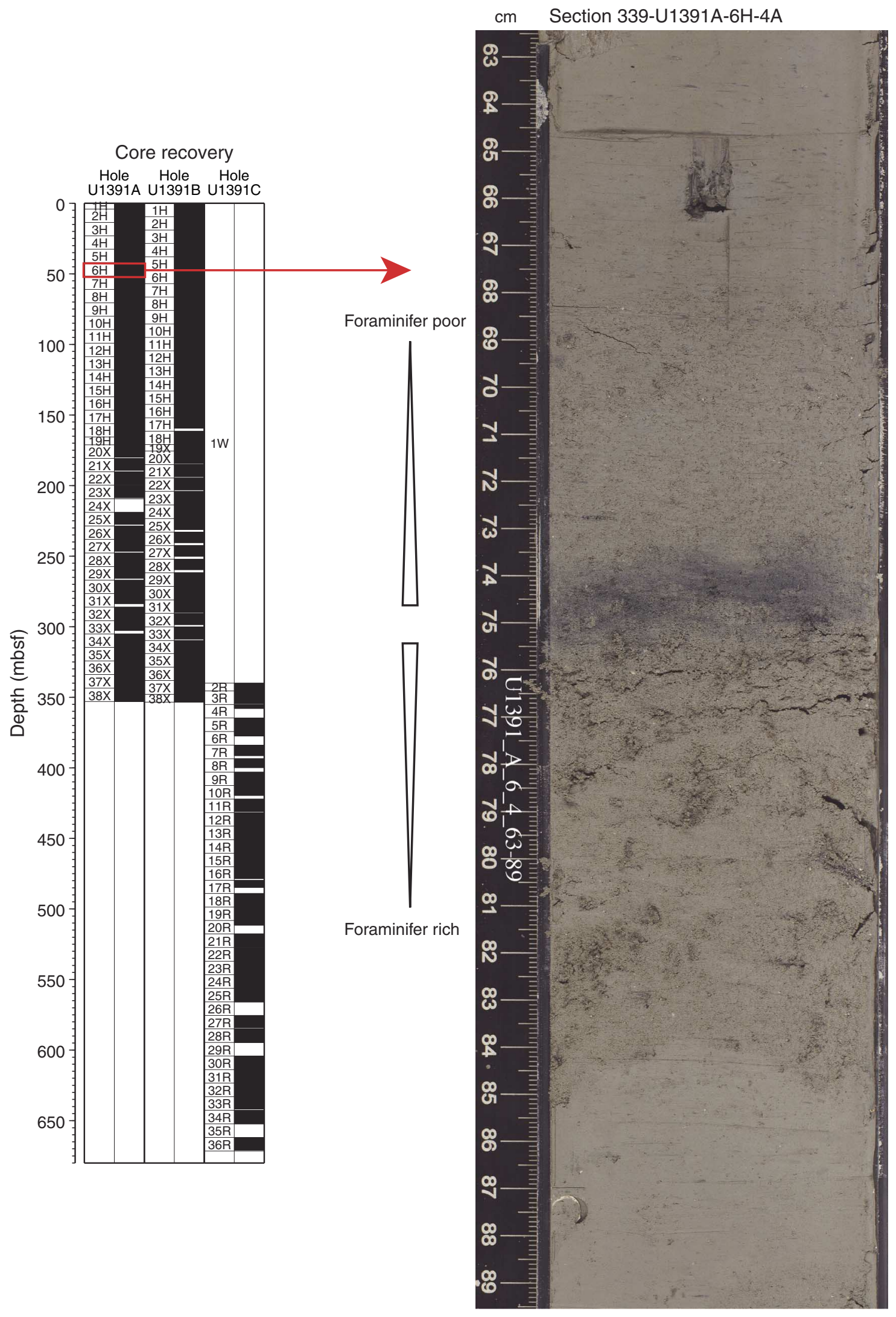


Figure F11. Core image of red-mottled mud (Section 339-U1391A-9H-5A).

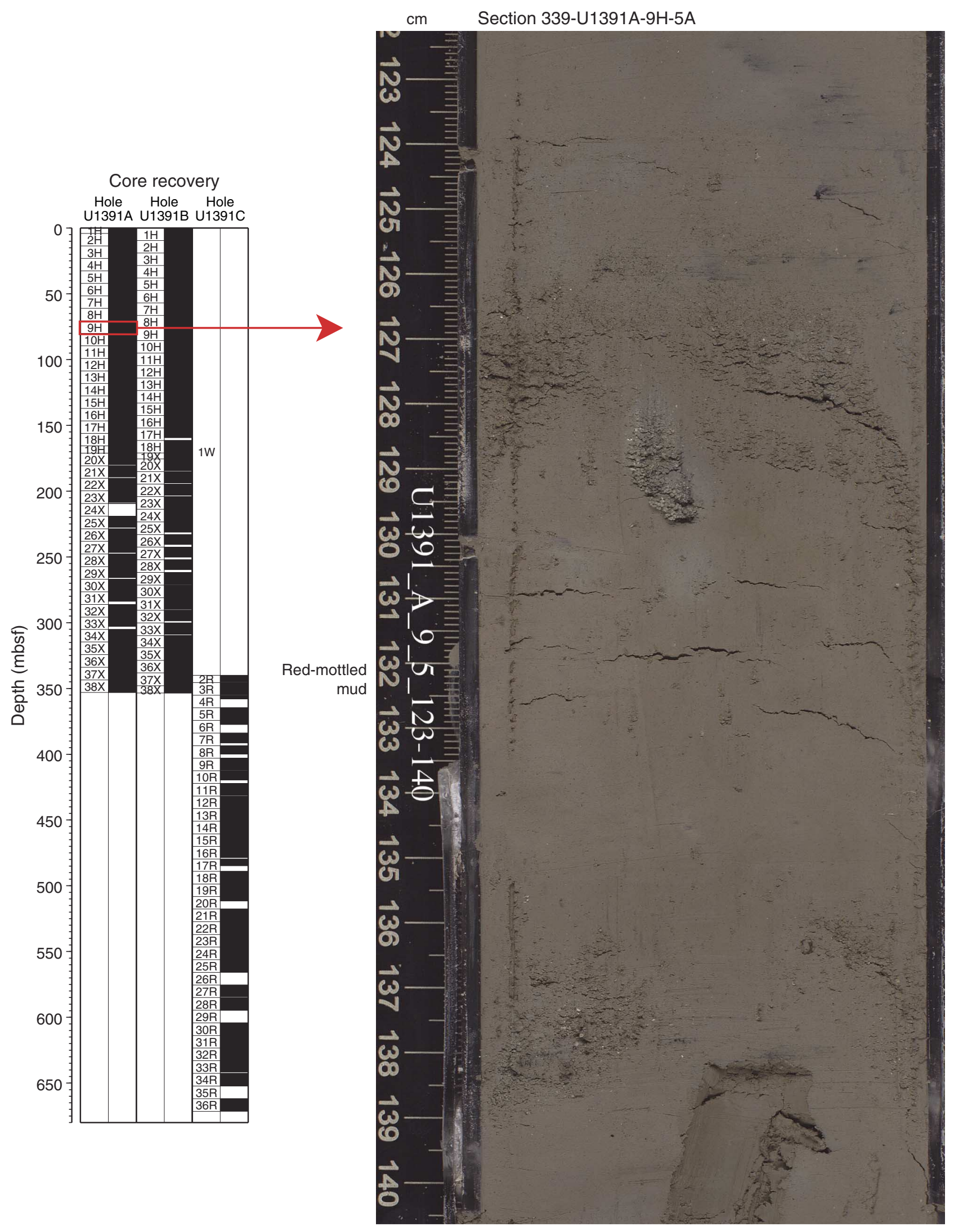


Figure F12. Core images of cross-laminated calcareous silt (Section 339-U1391C-15R-1A).

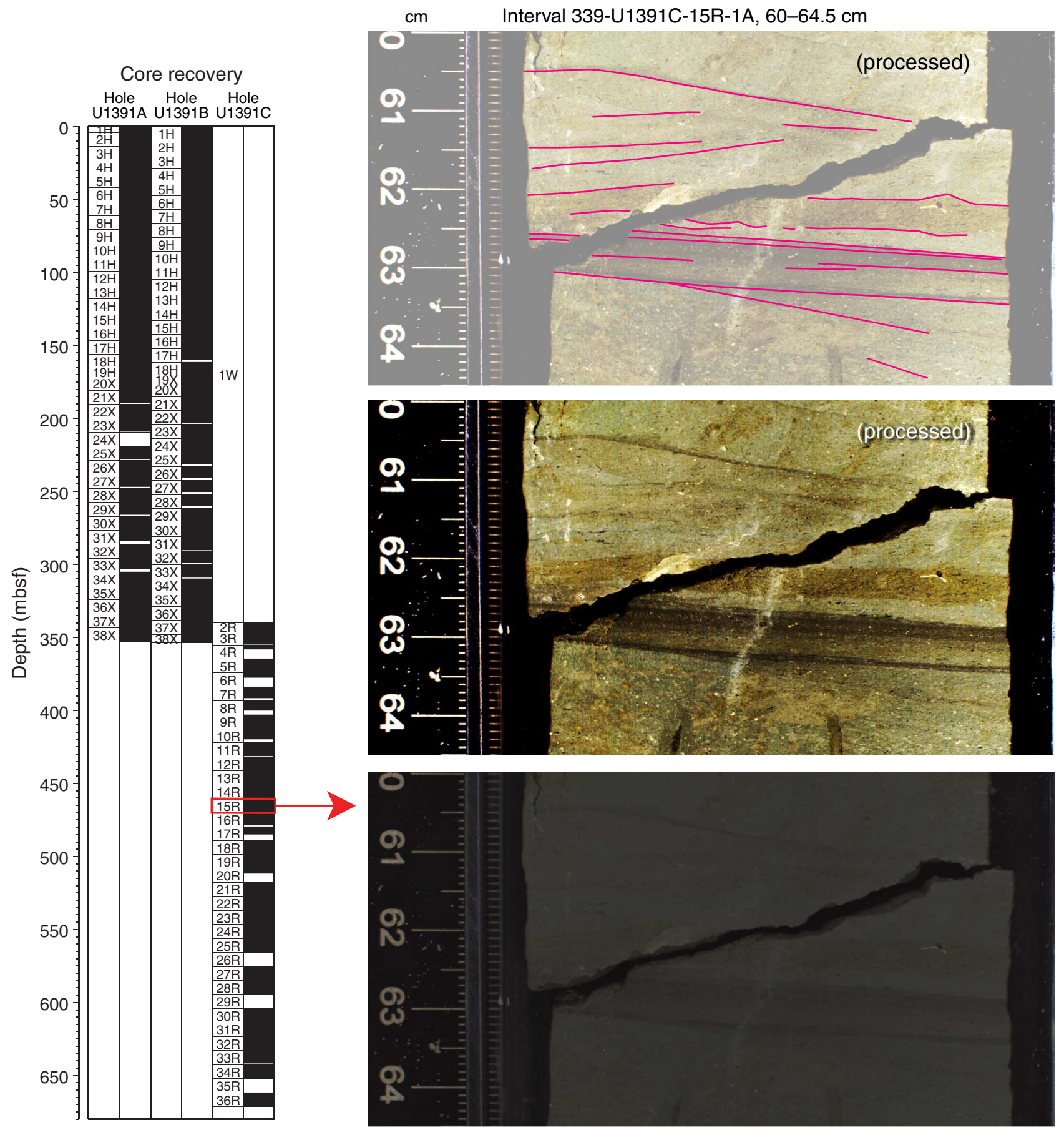


Figure F13. Core images of subparallel lamination in calcareous silt/mud (Section 339-U1391C-17R-4A).

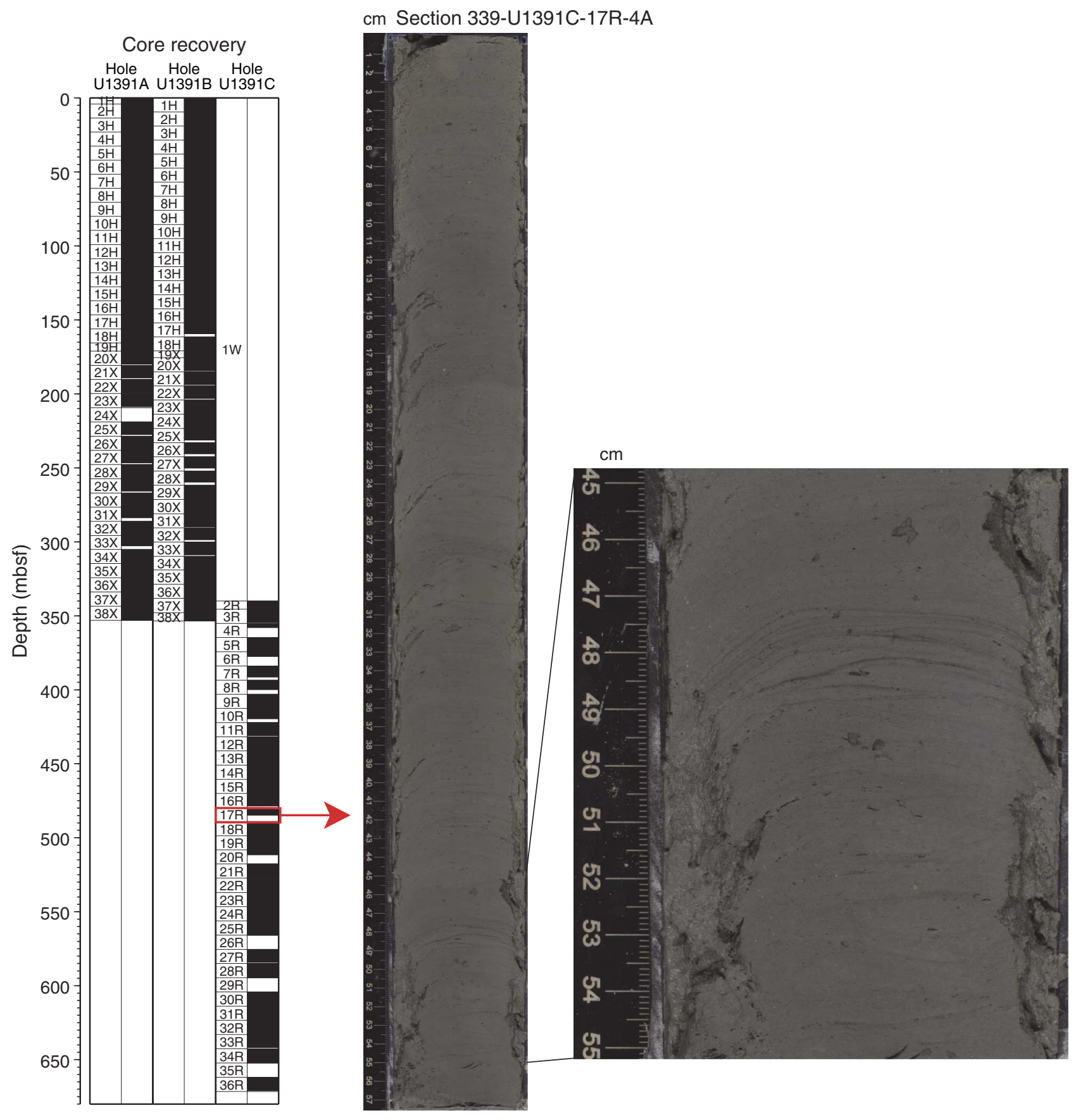


Figure F14. Core images of greenish gray to green color cycles (Section 339-U1391C-21R-1A).
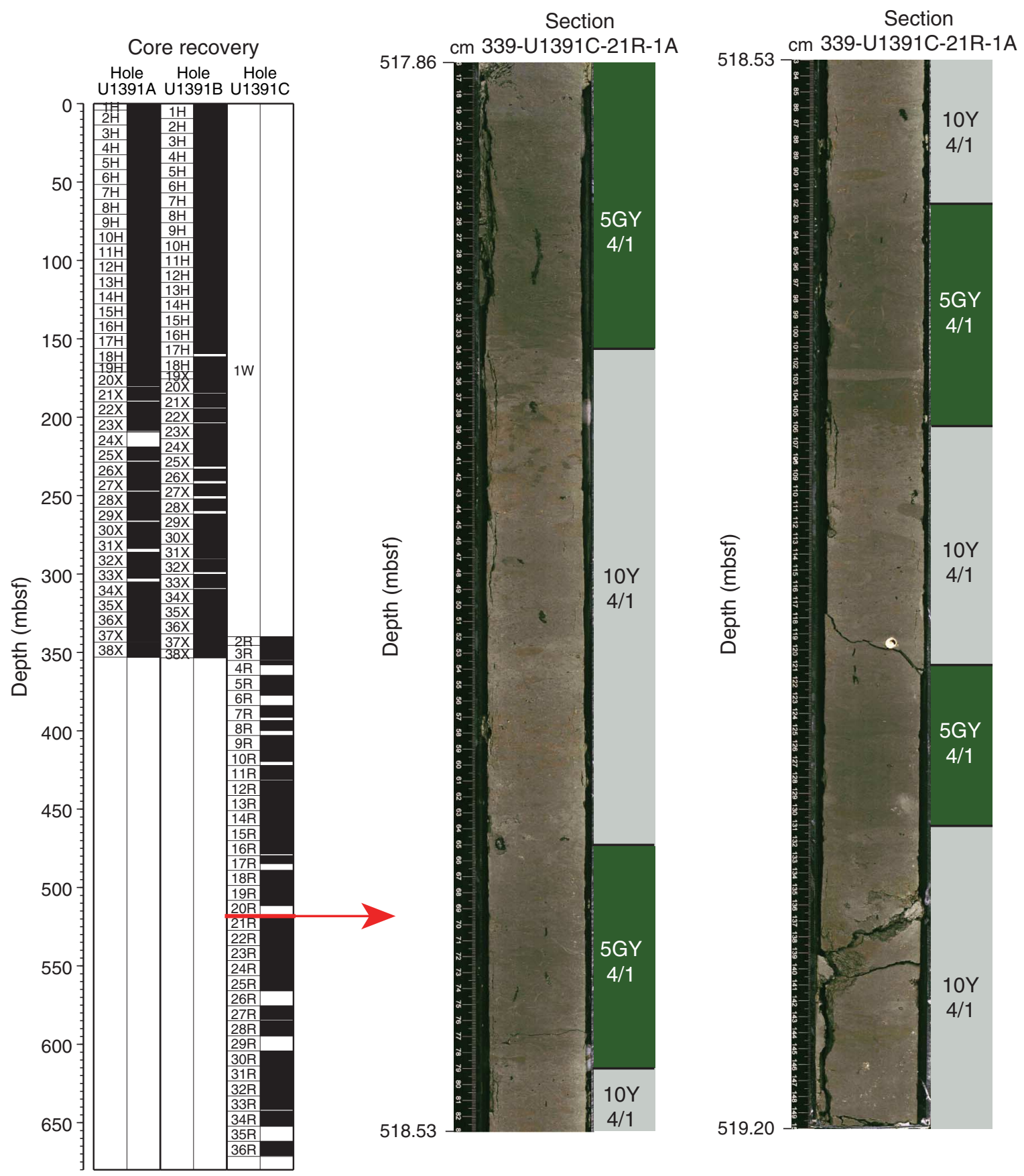
Figure F15. Core image of debrite (interval 339-U1391C-30R-1A, 0-38 cm).

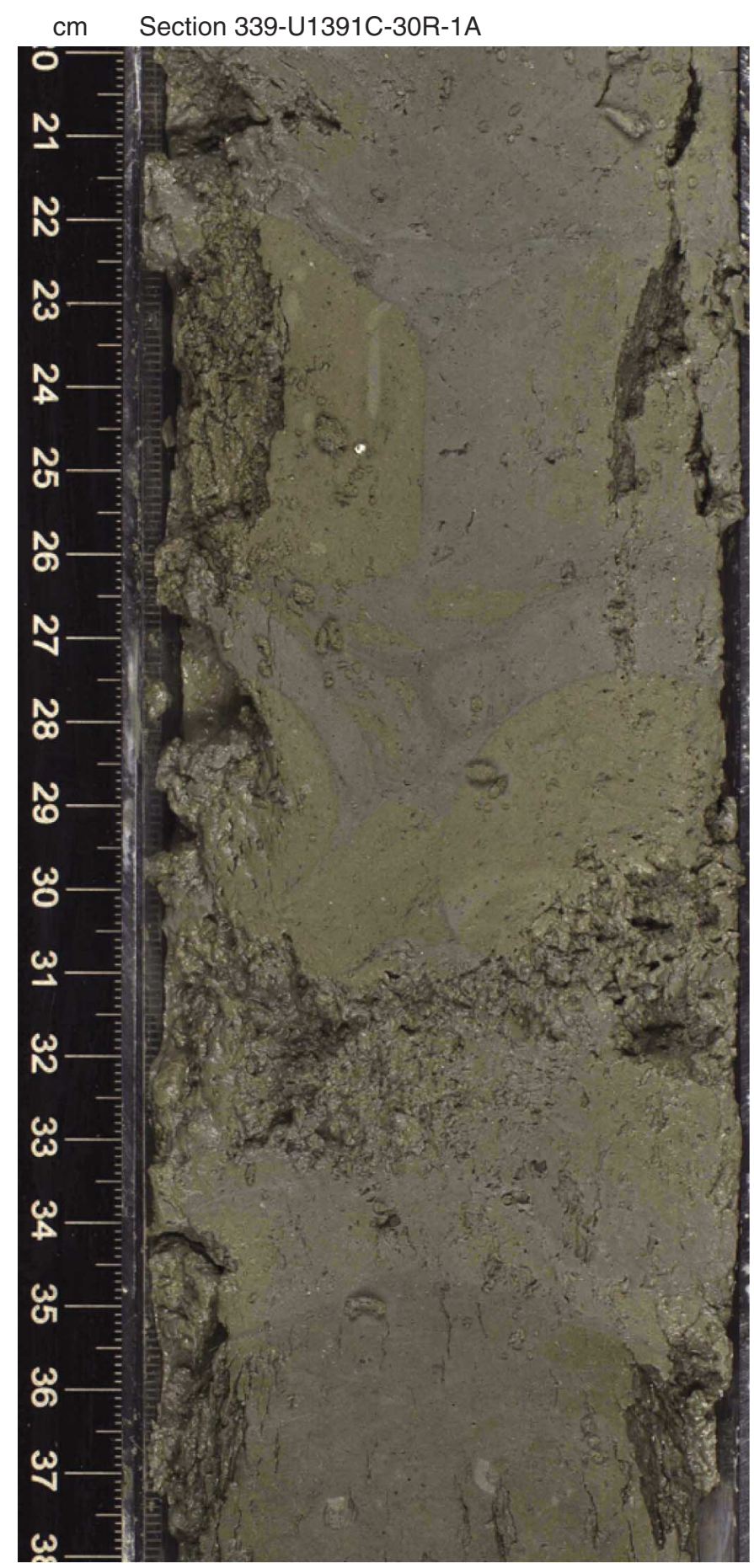


Figure F16. Core image and photomicrographs of dolomitic mudstone (interval 339-U1391C-32R-7A, 20-76 $\mathrm{cm})$. Top photomicrograph taken under plane-polarized light; bottom photomicrograph taken under cross-polarized light.

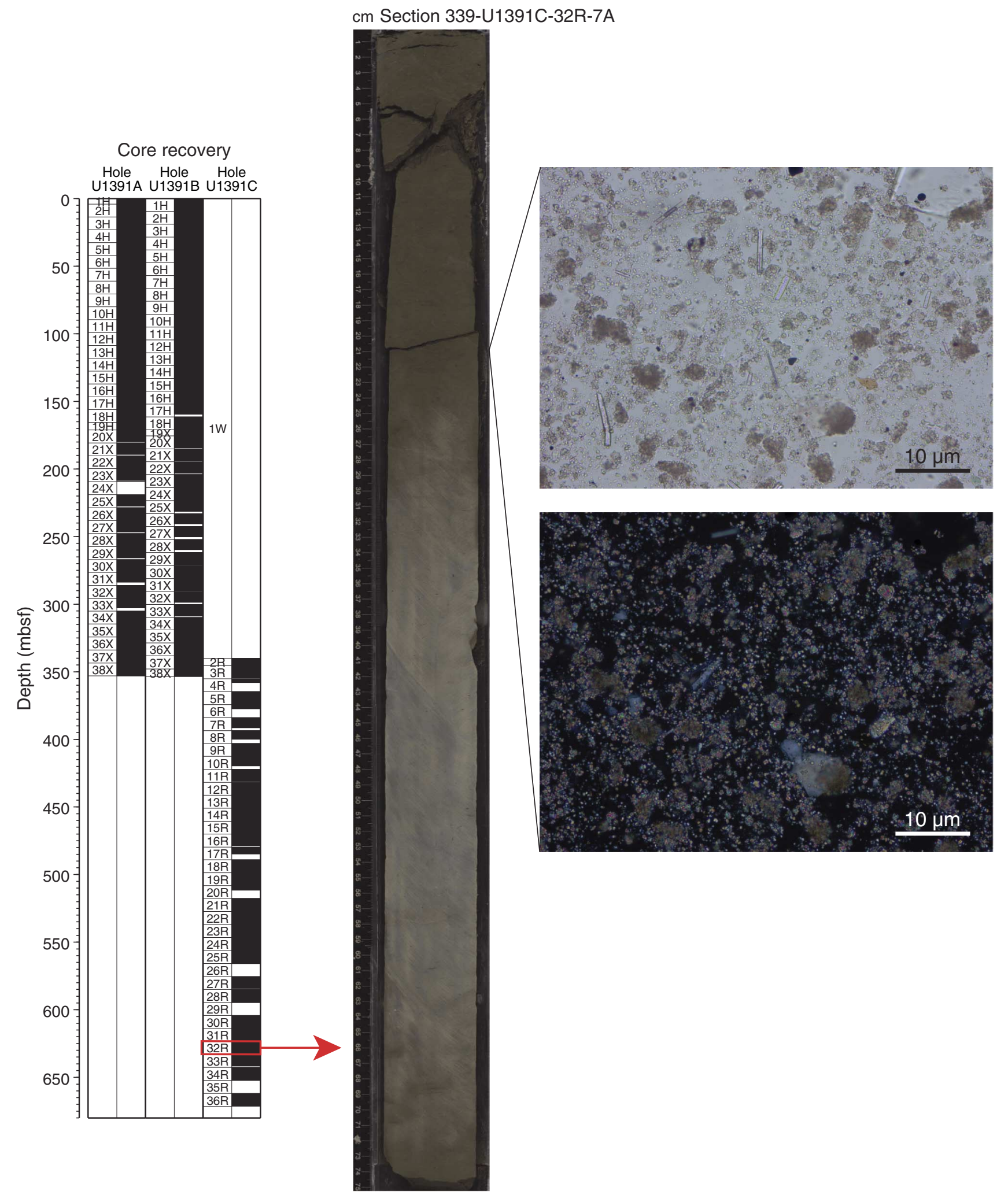


Figure F17. Core images of a microfault (interval 339-U1391C-34R-6, 29-53 cm).

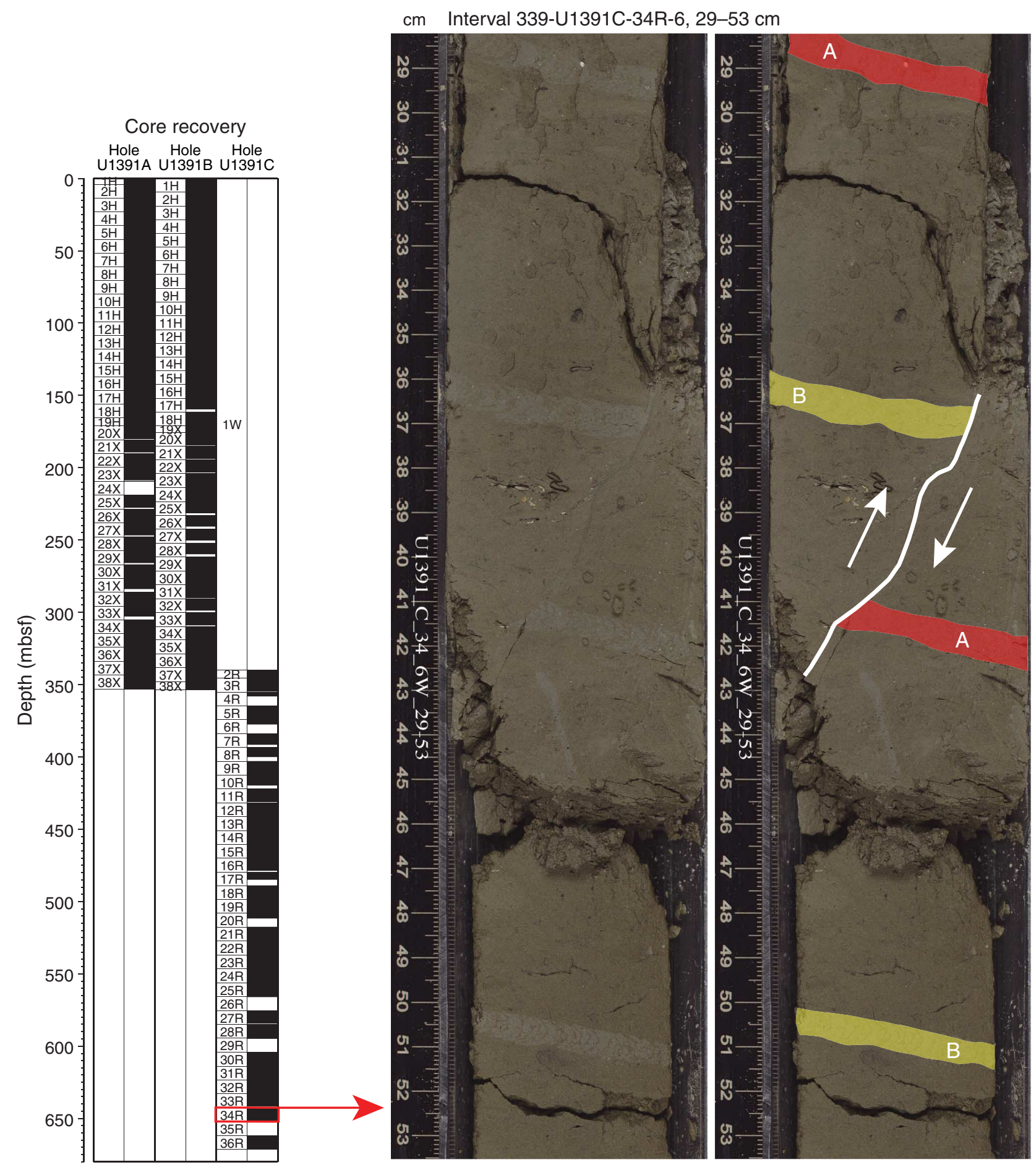


Figure F18. Biostratigraphic events vs. depth, Site U1391. Events are plotted at their mean depth (Table T4).

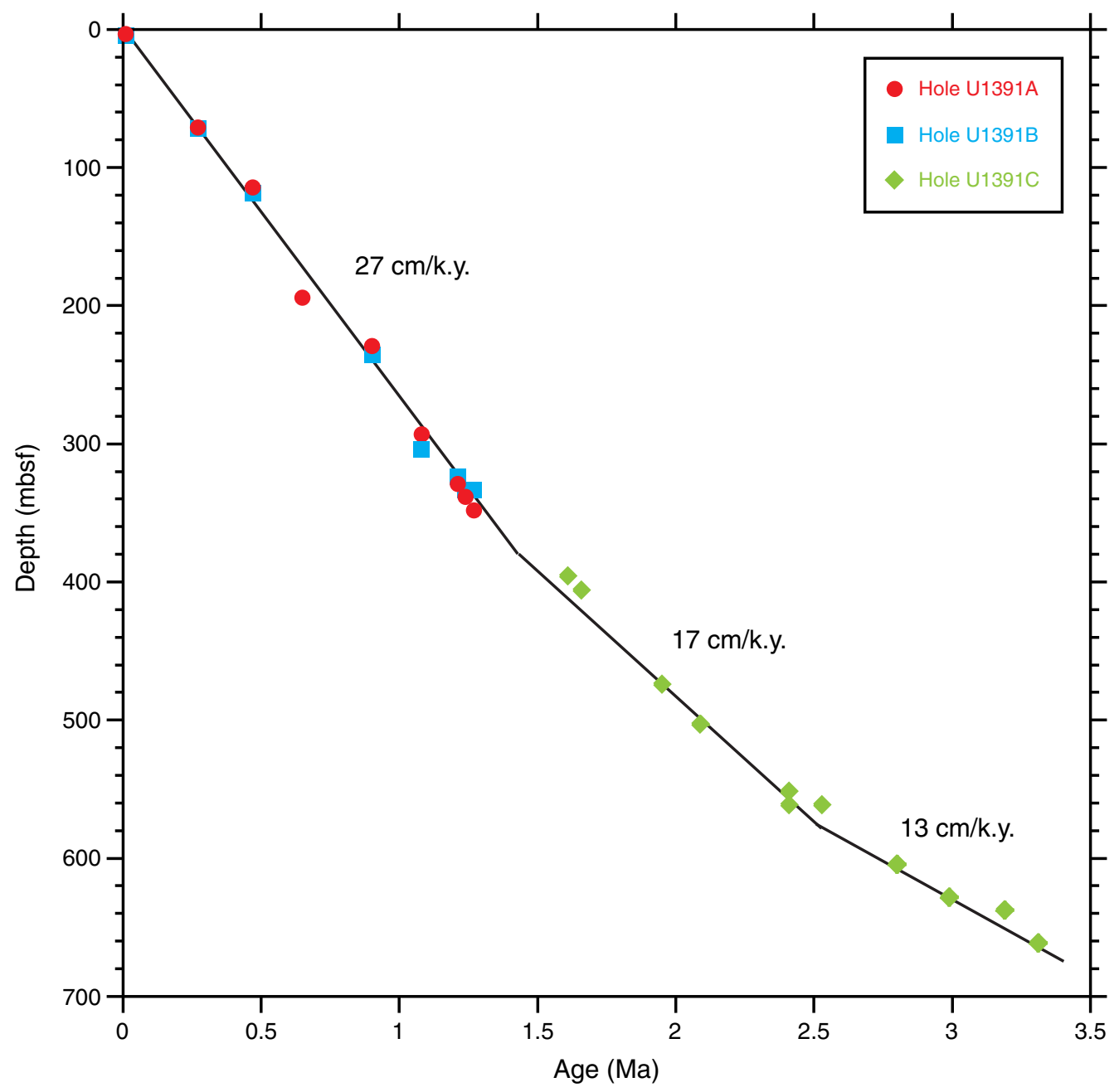

Pleistocene

Pliocene 

Quercus and Olea. Dashed lines indicate 10x magnification of concentrations. TPS = total pollen and spores. Preservation: $G=$ good, M $=$ moderate, $\mathrm{P}=$ poor.

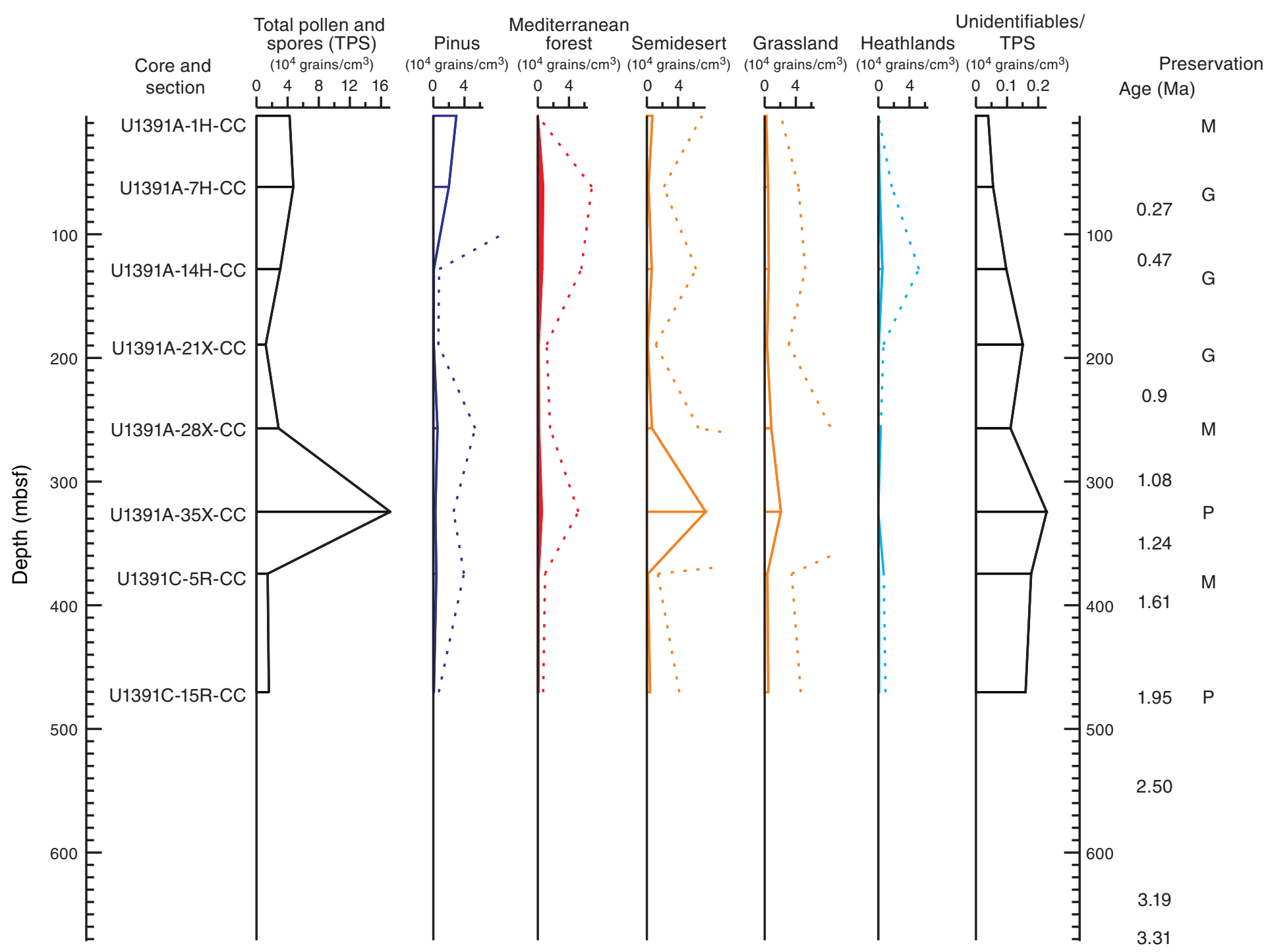


Figure F20. Paleomagnetism after $20 \mathrm{mT}$ peak field AF demagnetization, Site U1391. In the Chron column, black $=$ normal polarity, white $=$ reversed polarity, and gray $=$ zones or polarity boundaries without a clear magnetostratigraphic interpretation. In Inclination column, blue dashed lines = expected geocentric axial dipole inclinations at the site latitude during reversed (left) and normal (right) polarities. In Declination column, light blue circles $=$ measured declinations and dark blue circles $=$ FlexIt tool-corrected declinations. In Susceptibility column, gray lines represent SHMSL susceptibility plus $25 \times 10^{-5}$ volume SI to better show the comparison with WRMSL susceptibility (black lines). (Figure shown on next three pages.) 
Figure F20 (continued). A. Hole U1397A. (Caption shown on previous page.) (Continued on next page.)

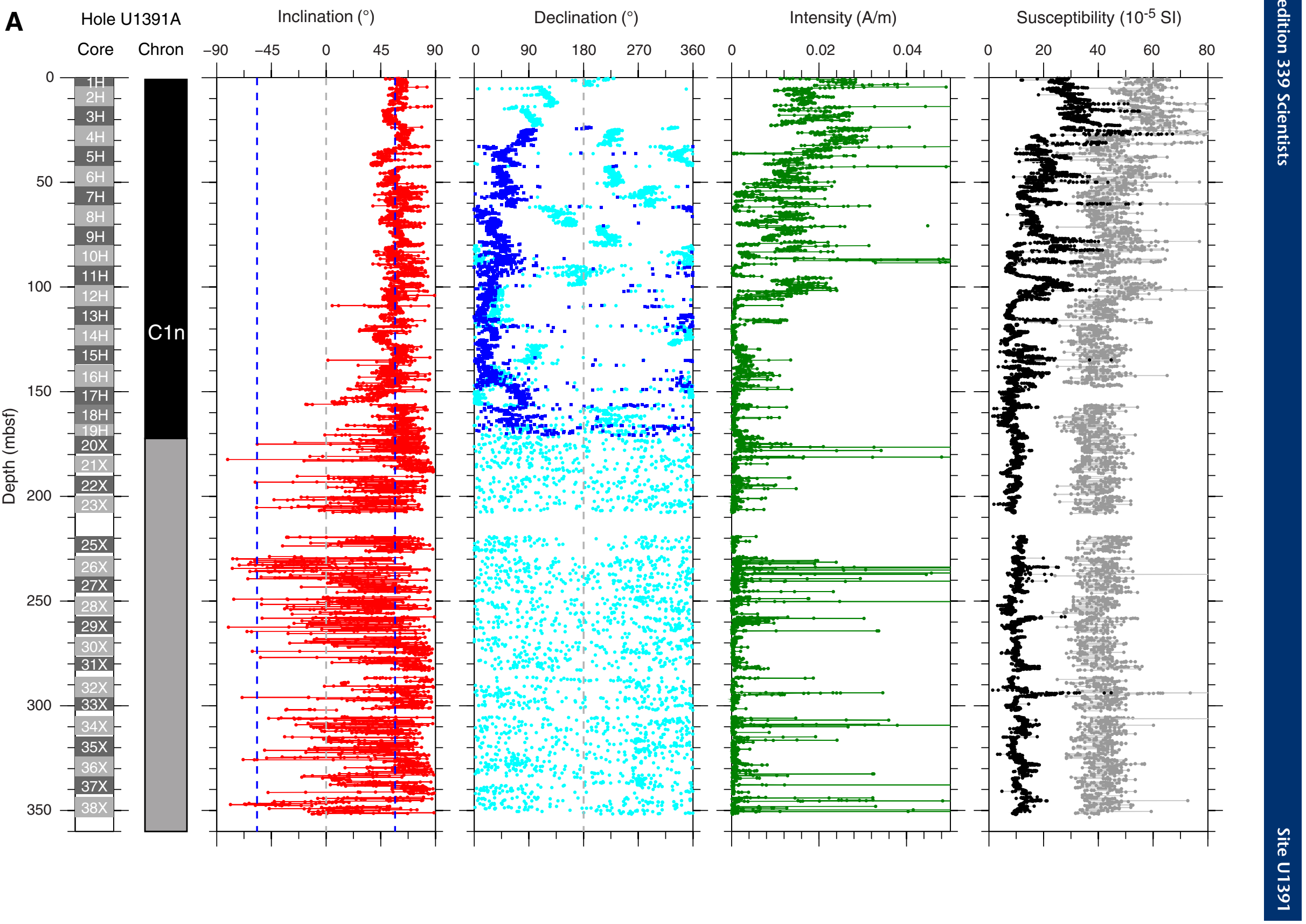


Figure F20 (continued). B. Hole U1391B. (Continued on next page.)

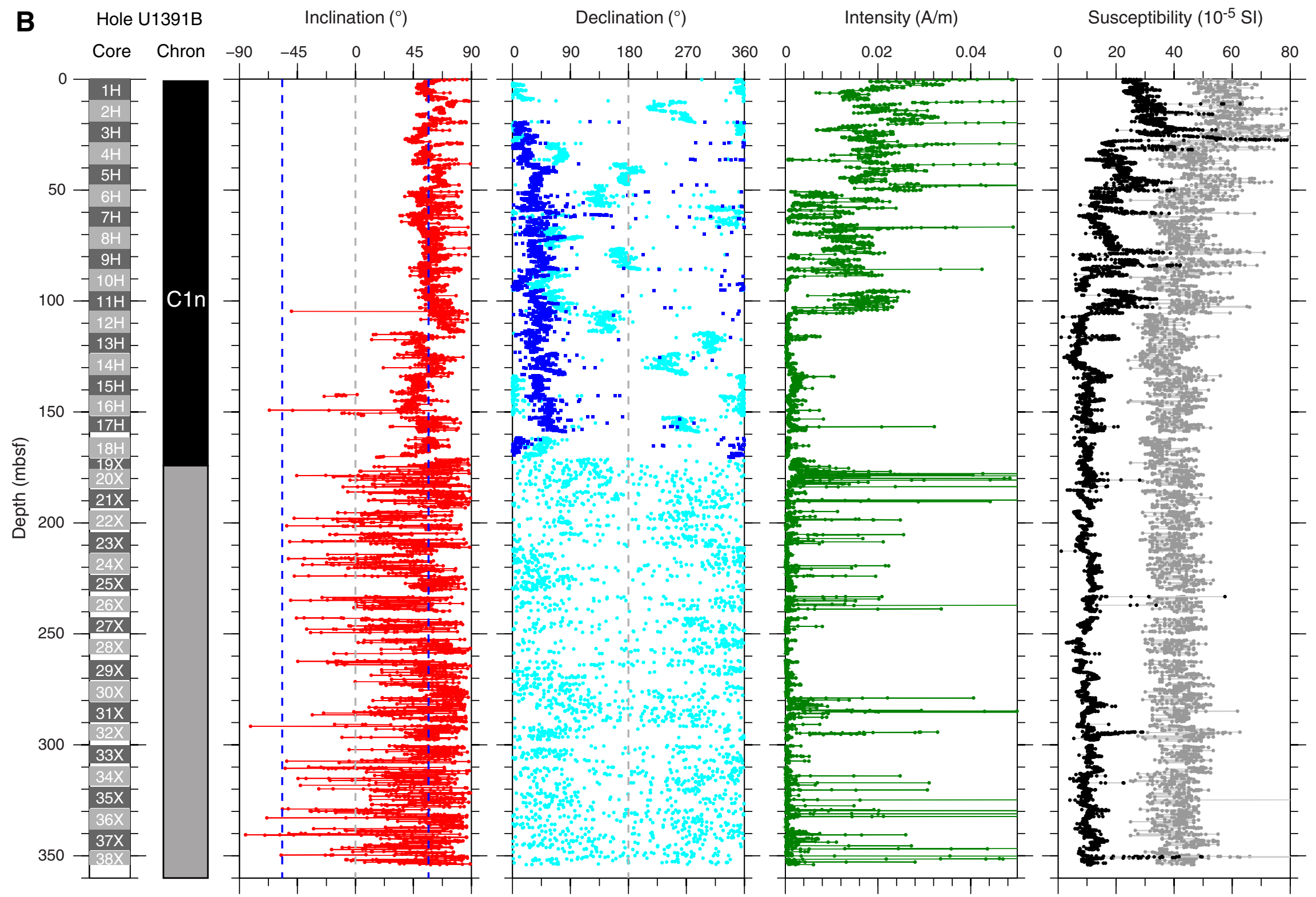


Figure F20 (continued). C. Hole U1391C.

C

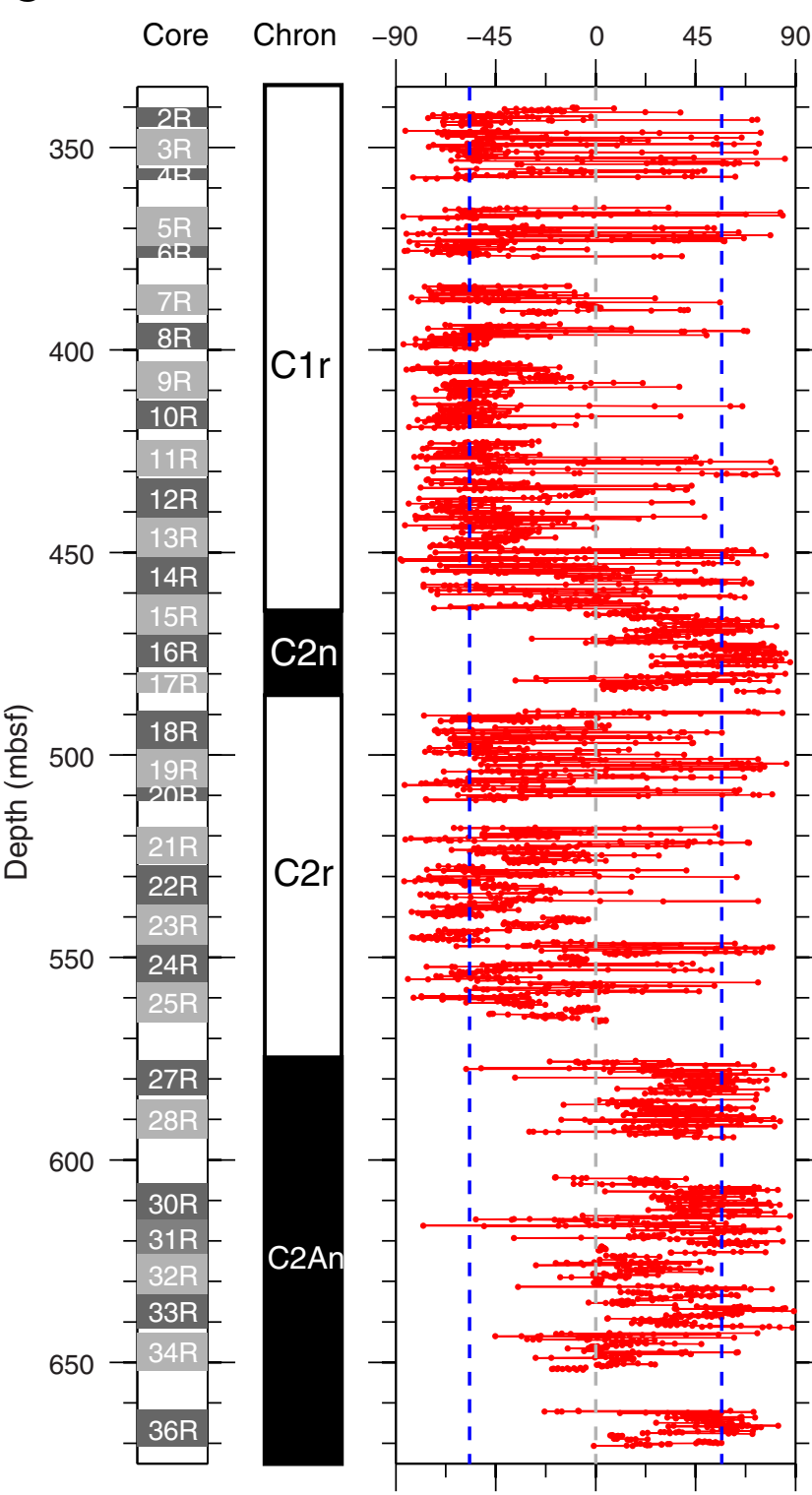

Declination $\left({ }^{\circ}\right)$

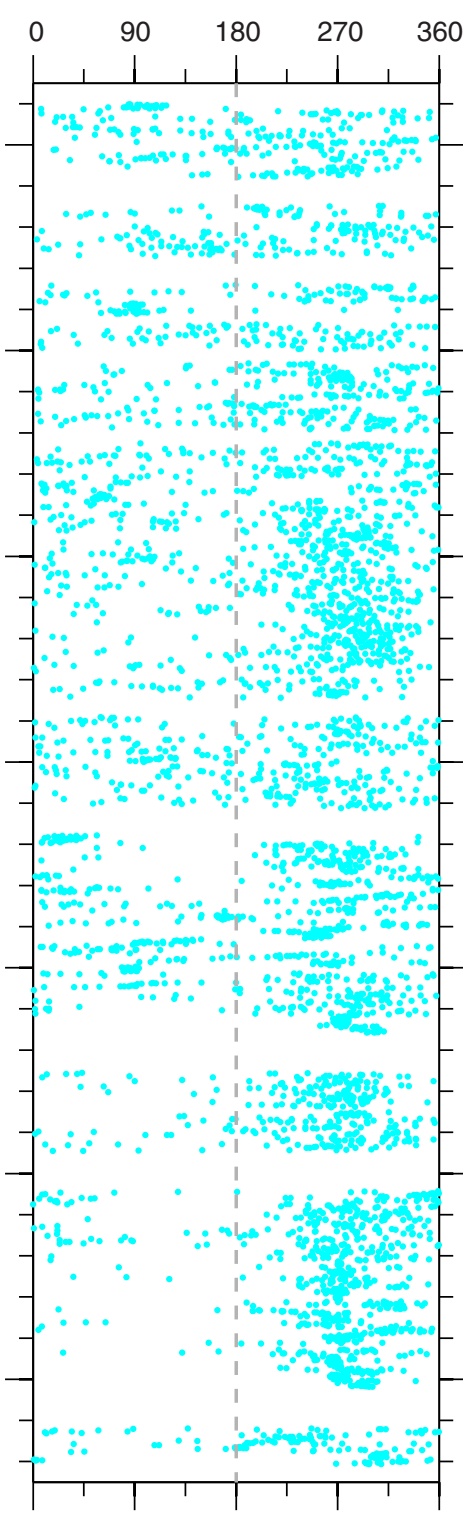

Intensity $(\mathrm{A} / \mathrm{m})$

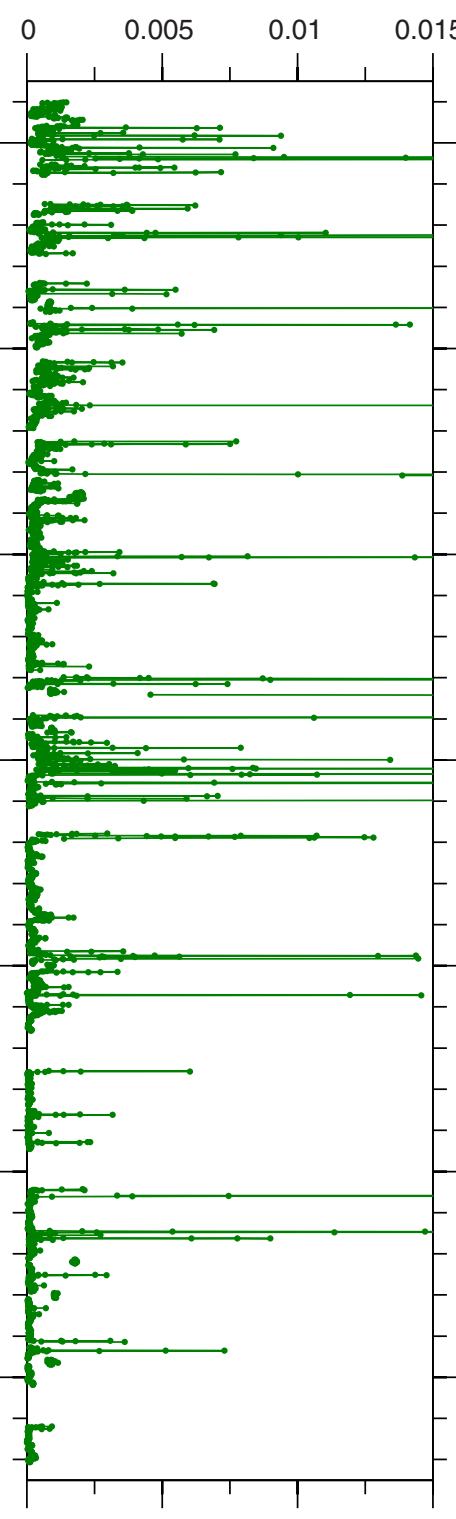

Susceptibility $\left(10^{-5} \mathrm{SI}\right)$

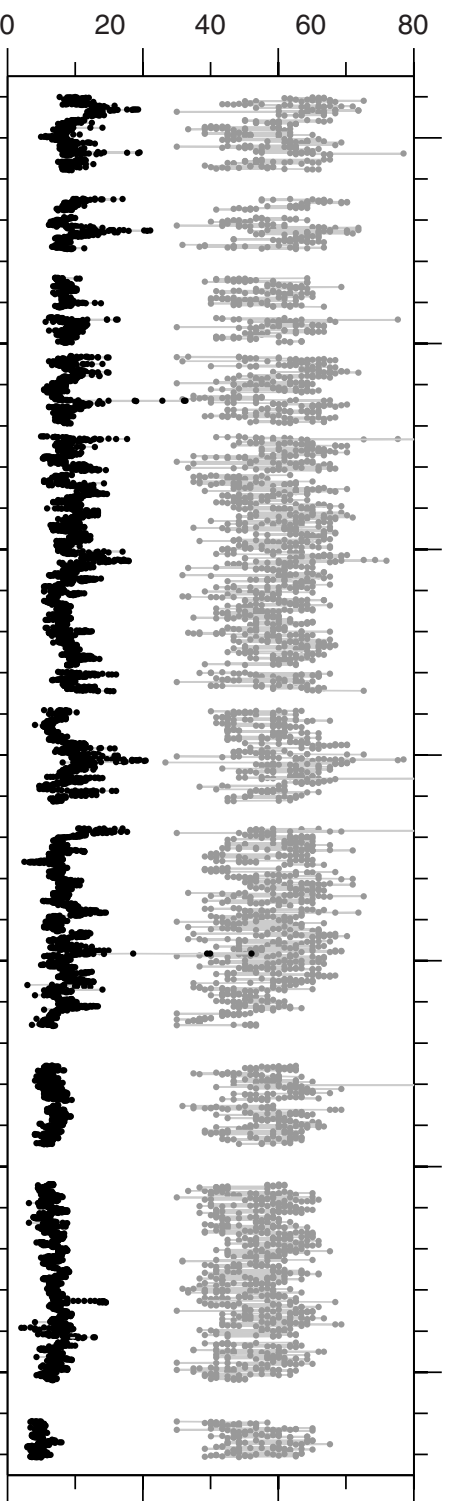


Figure F21. Plots of $P$-wave velocity (PWV) measured on the Whole Round Multisensor Logger (WRMSL; green line) and Section-Half Measurement Gantry (discrete samples) set to automatic (solid circles) and manual (open circles) mode, wet bulk density obtained on discrete samples (red diamonds), gamma ray attenuation density measured on the WRMSL (black lines), and magnetic susceptibility (MS) measured on the WRMSL (black lines) and on split cores (green points). Note that records were cleaned for outliers and bad data at sections ends. PP = physical property. A. Hole U1391A. (Continued on next page.)

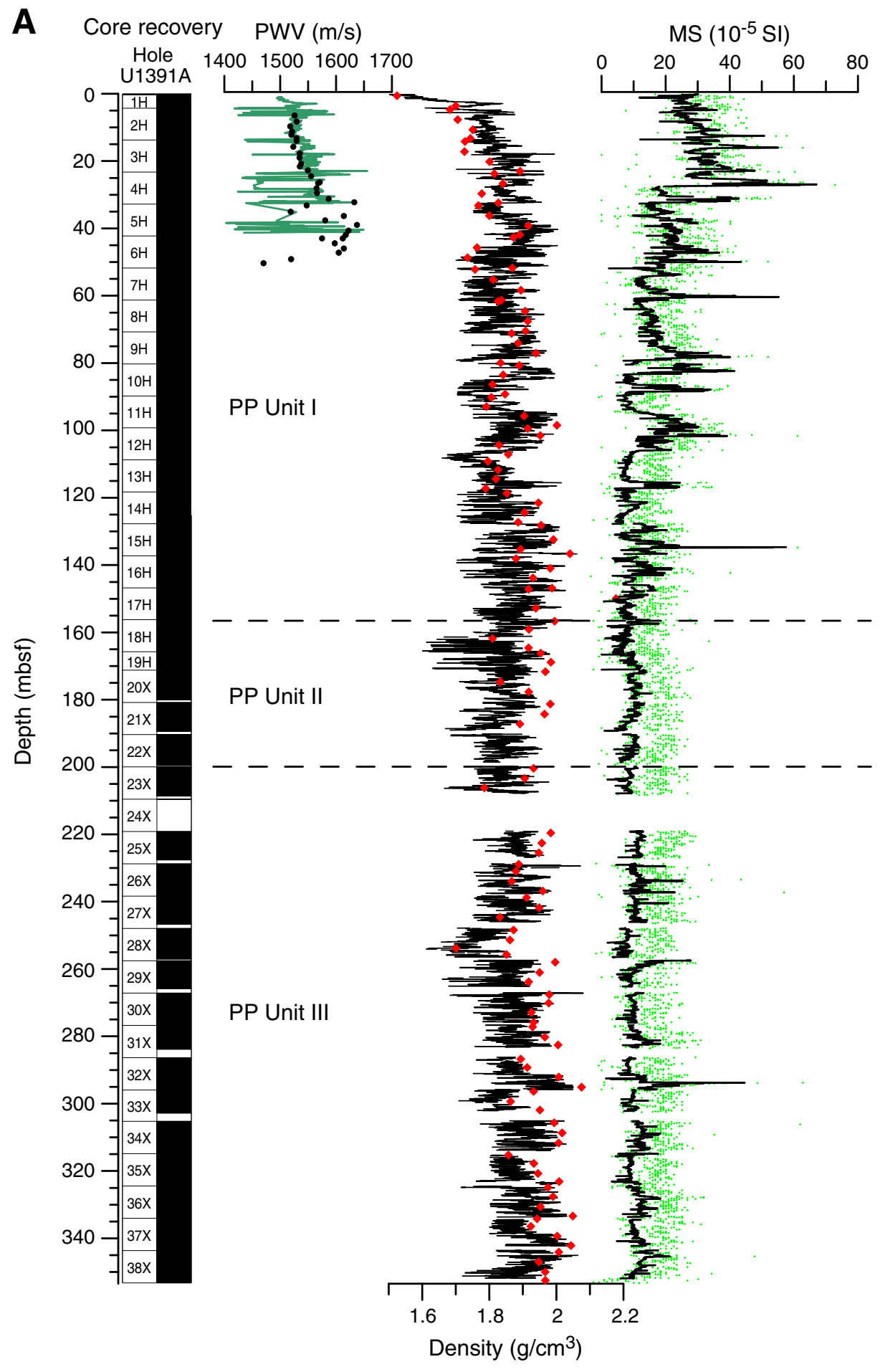


Figure F21 (continued). B. Hole U1391C.

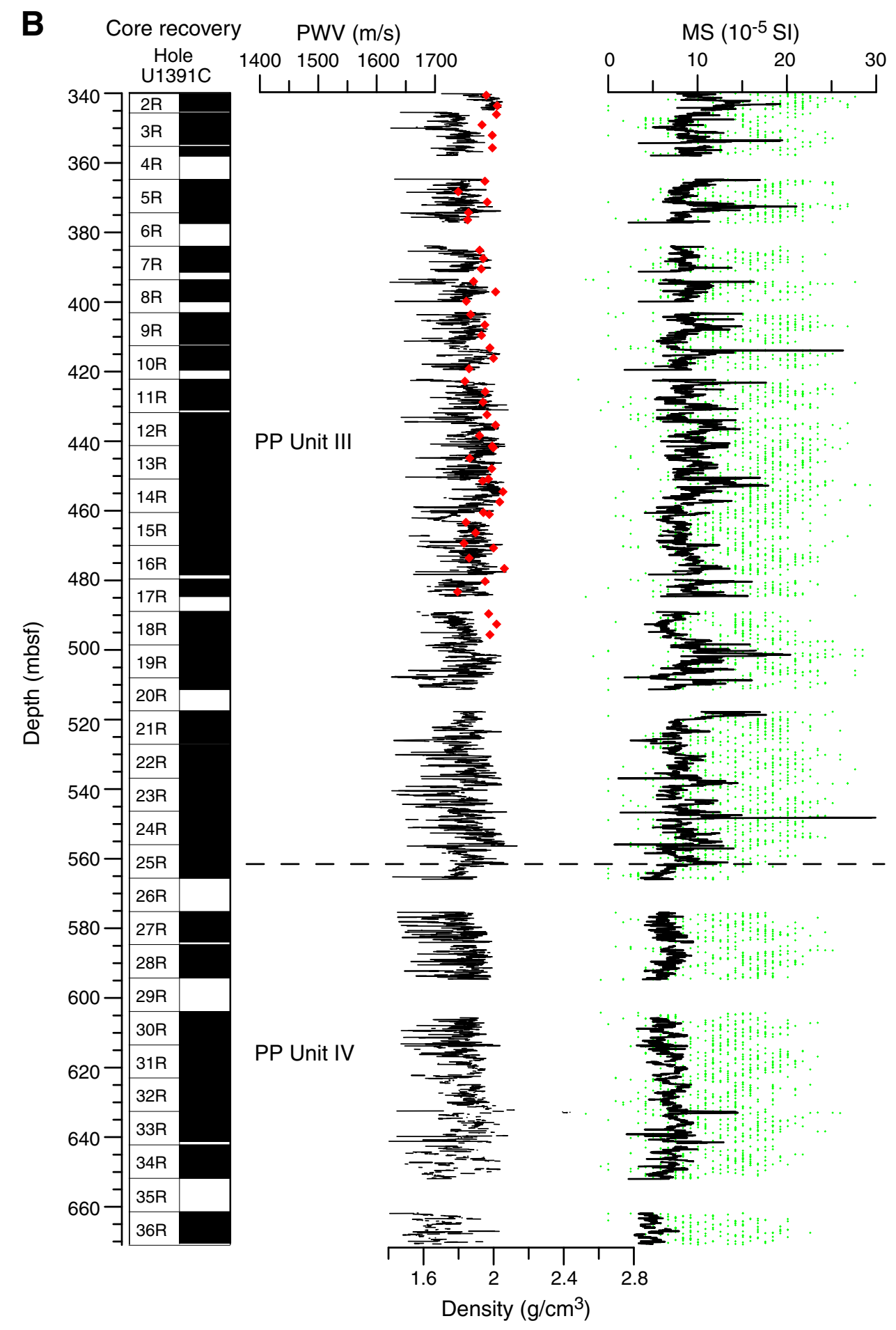


Figure F22. Plots of color reflectance $\left(\mathrm{L}^{*}, \mathrm{a}^{*}\right)$ and natural gamma ray (NGR) measurements. Note that data were cleared for outliers and bad data at section ends. Reflectance data were smoothed with a 10-point running mean. $\mathrm{PP}=$ physical property. A. Hole U1391A. (Continued on next page.)

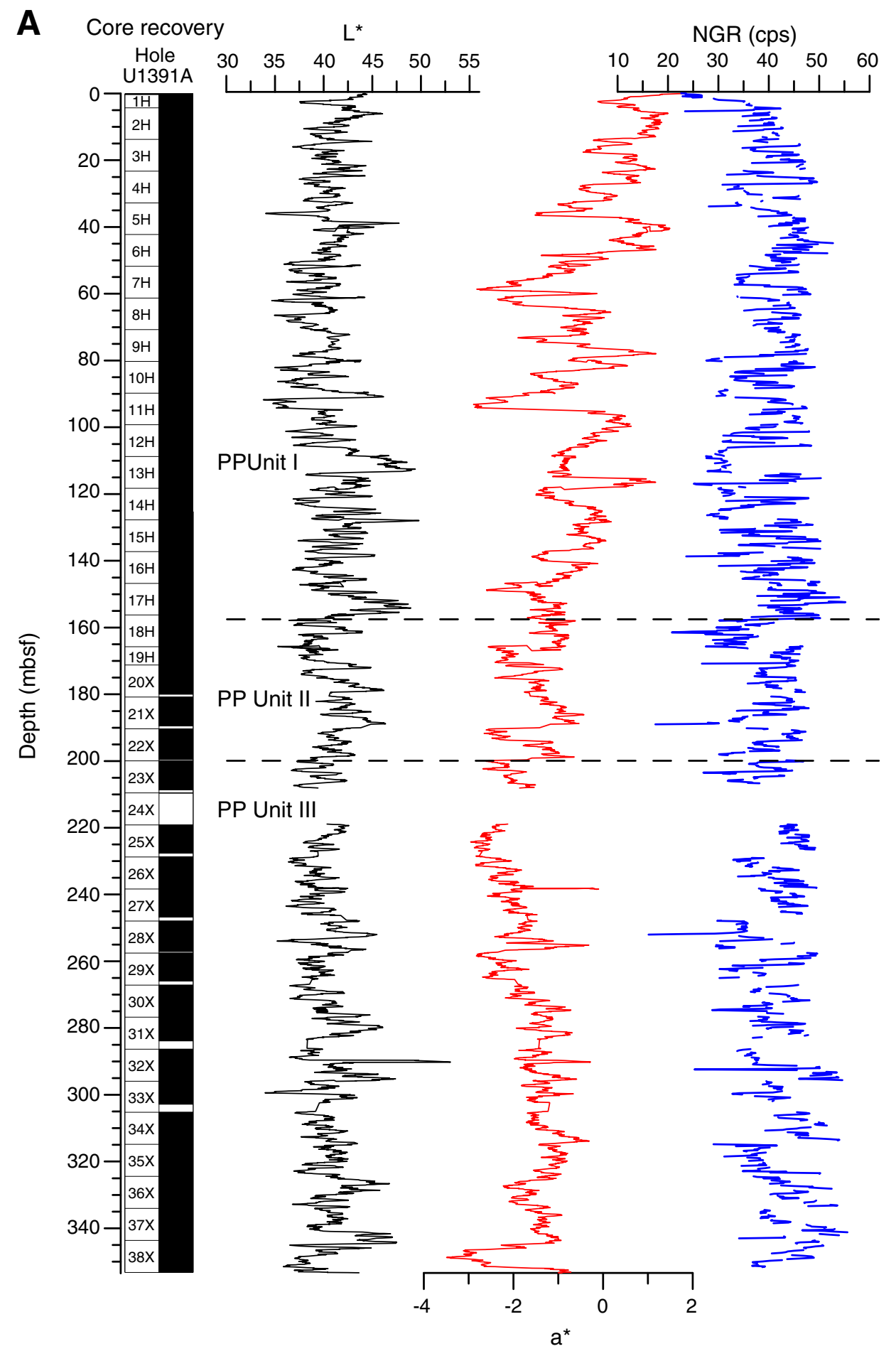


Figure F22 (continued). B. Hole U1391C.

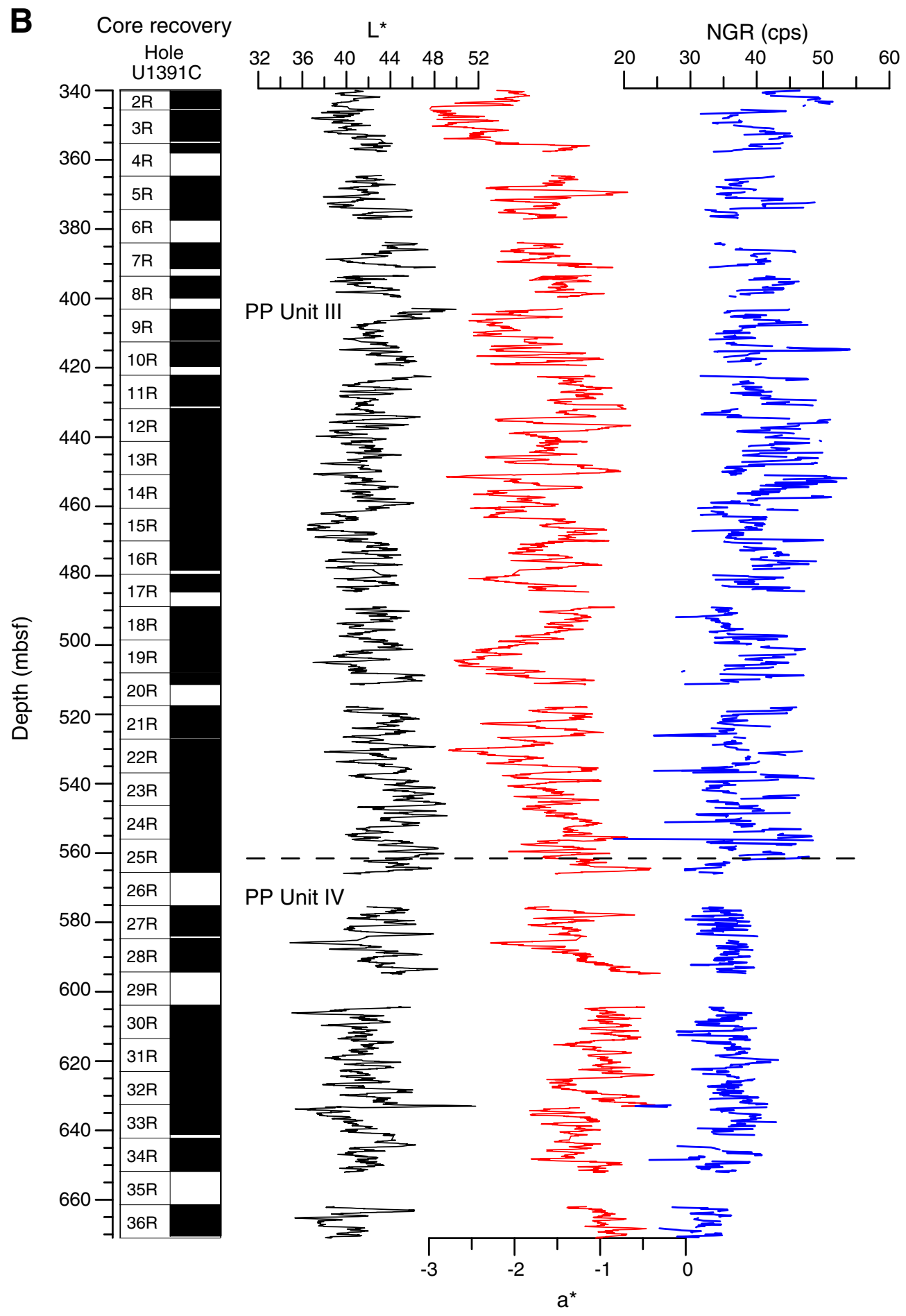


Figure F23. Plots of downhole distribution of discrete measurements of grain density, moisture content, and porosity. $\mathrm{PP}=$ physical property. A. Hole U1391A. (Continued on next page.)

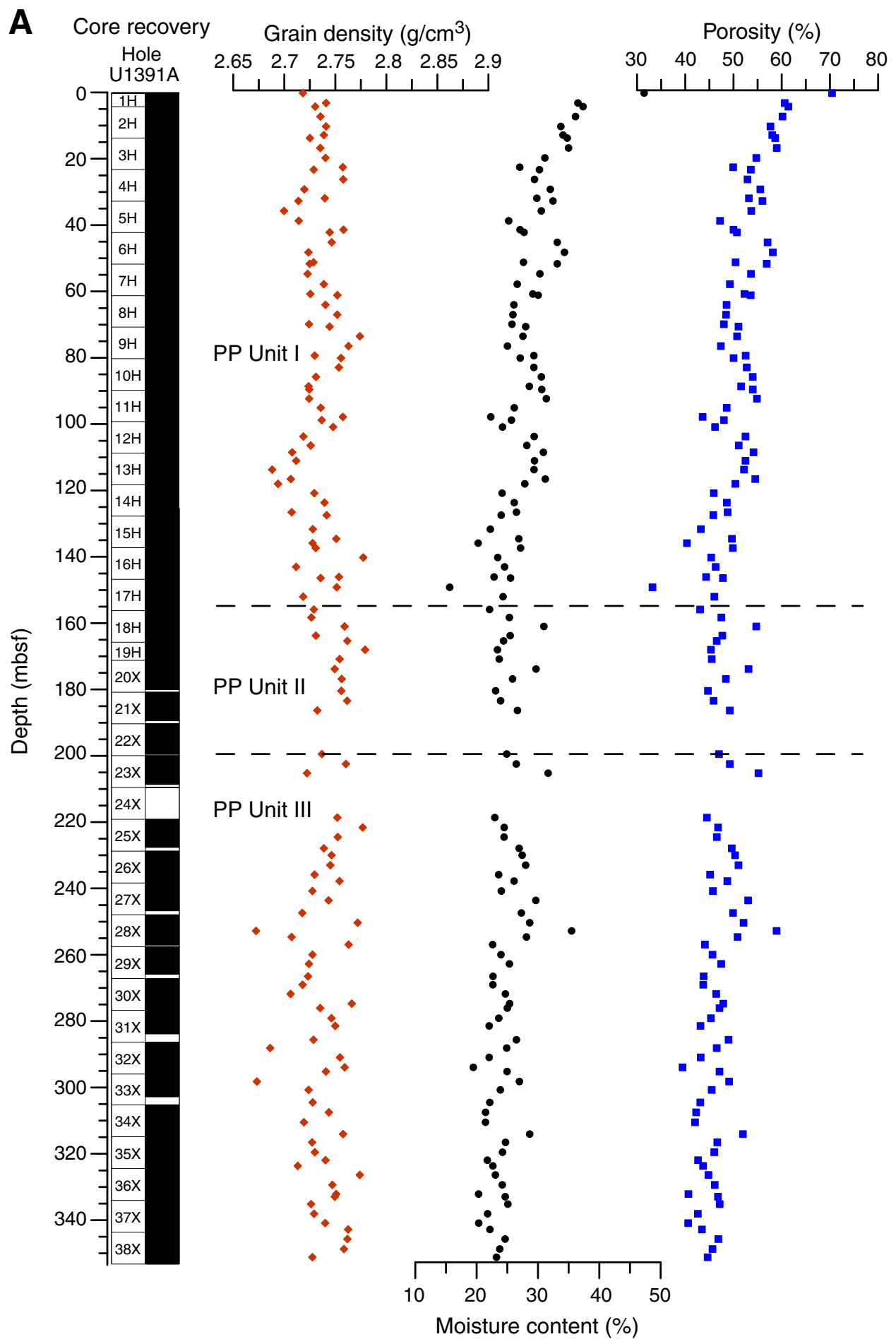


Figure F23 (continued). B. Hole U1391C.

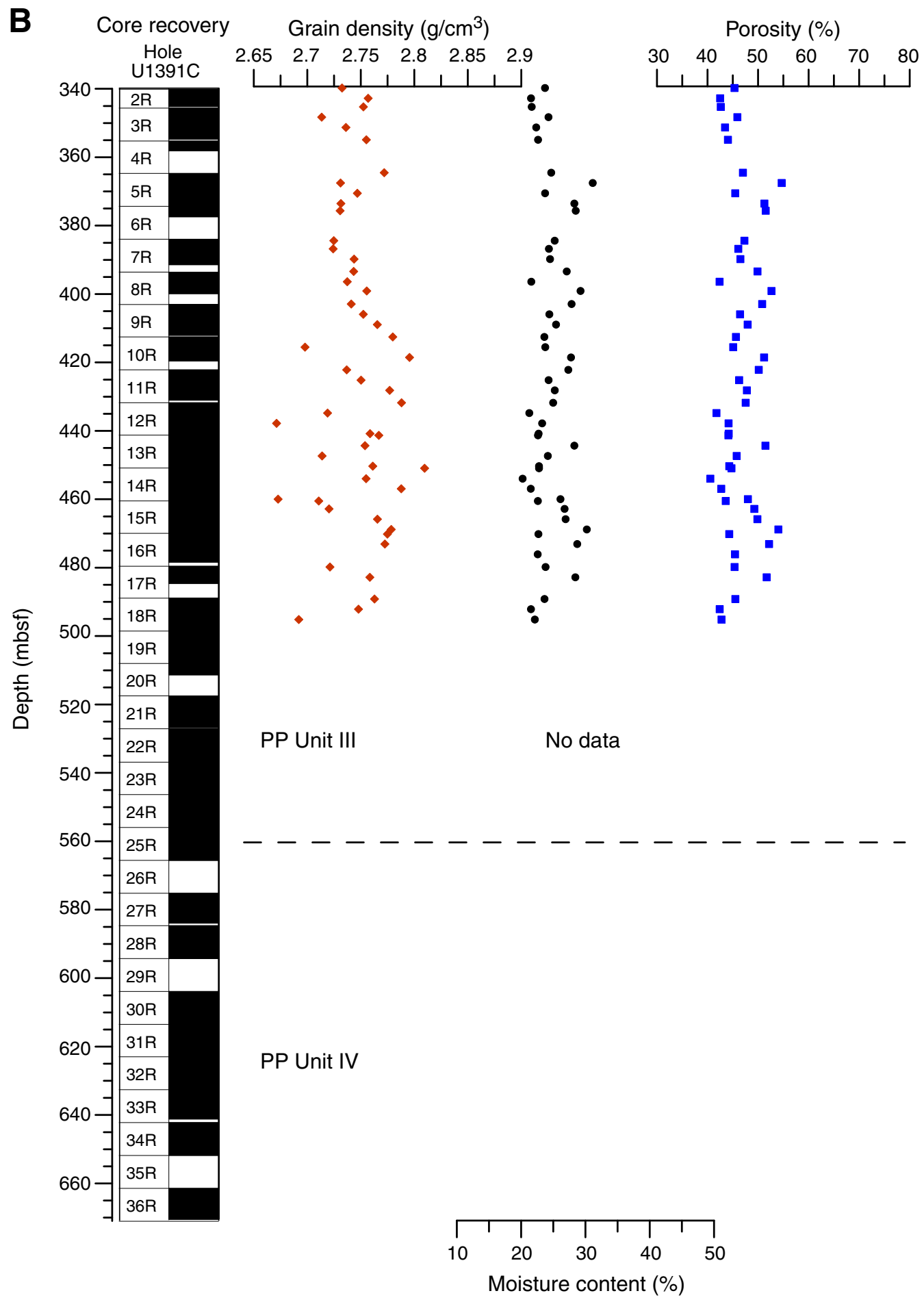


Figure F24. Plot of headspace gas analyses for volatile hydrocarbons, Holes U1391A and U1391C.

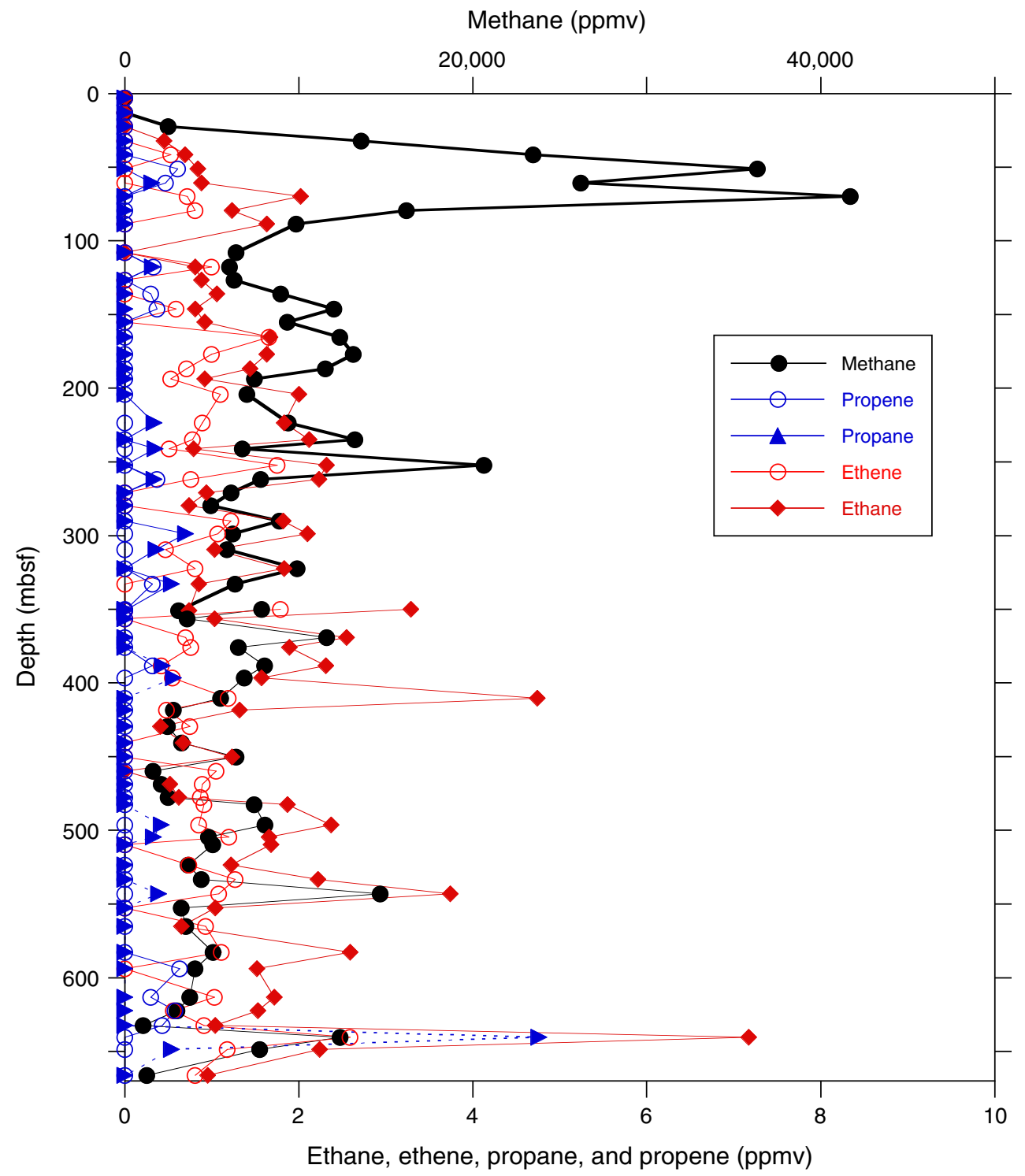


Figure F25. Plot of calcium carbonate, Hole U1391A.

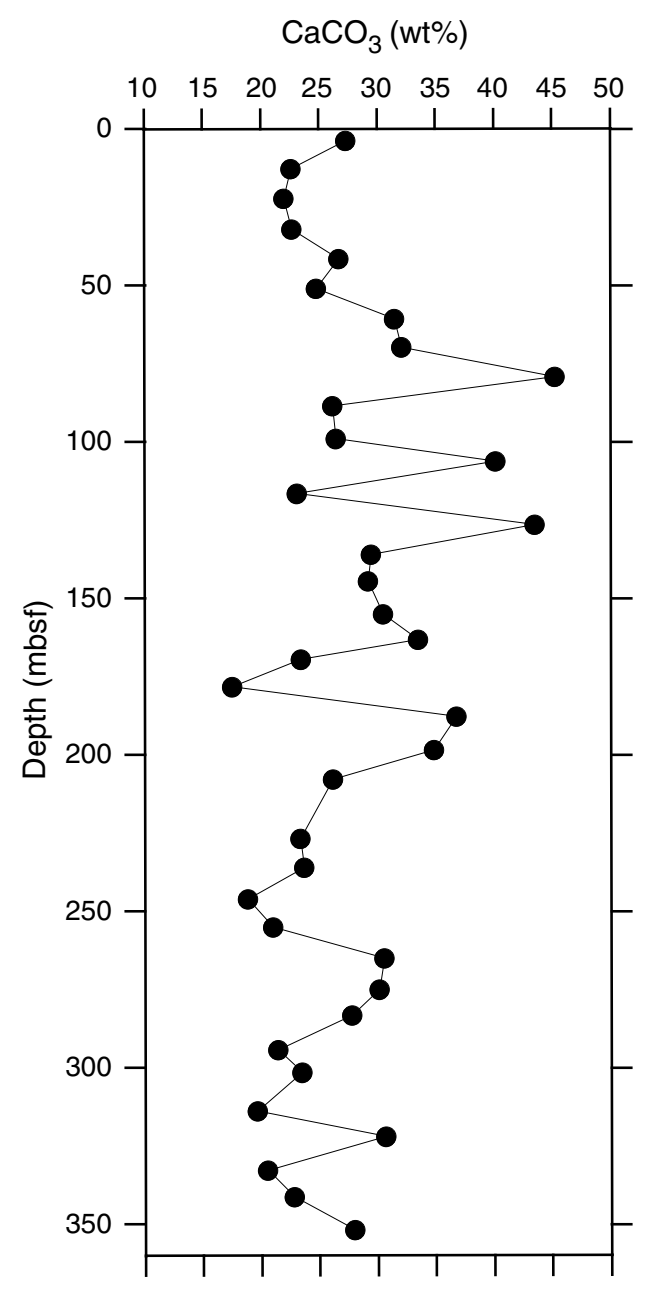


Figure F26. A-C. Plots of calculated total organic carbon (TOC), total nitrogen (TN), and C/N ratio, Hole U1391A.

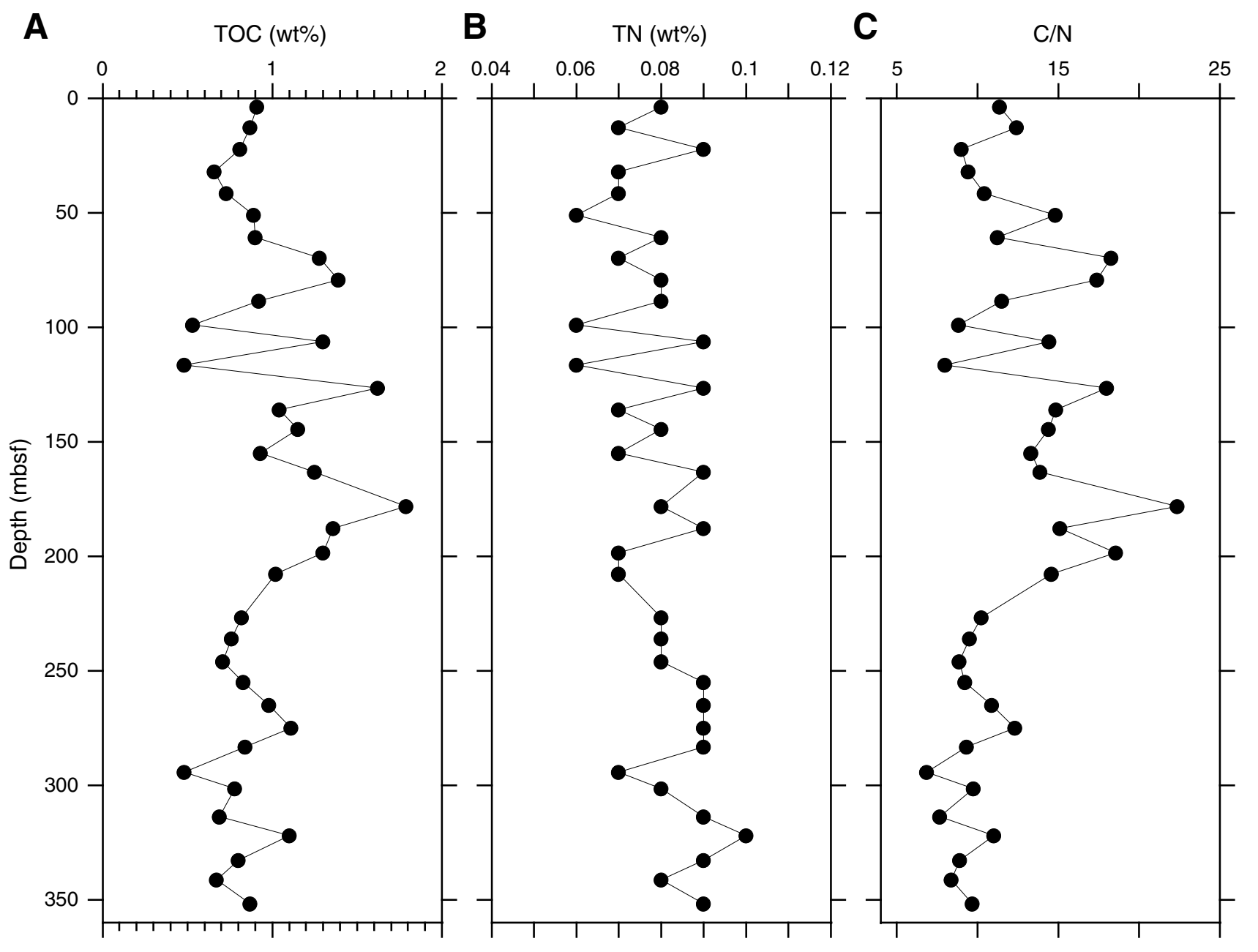


Figure F27. A-C. Plots of interstitial water sulfate, ammonium, and alkalinity, Site U1391.

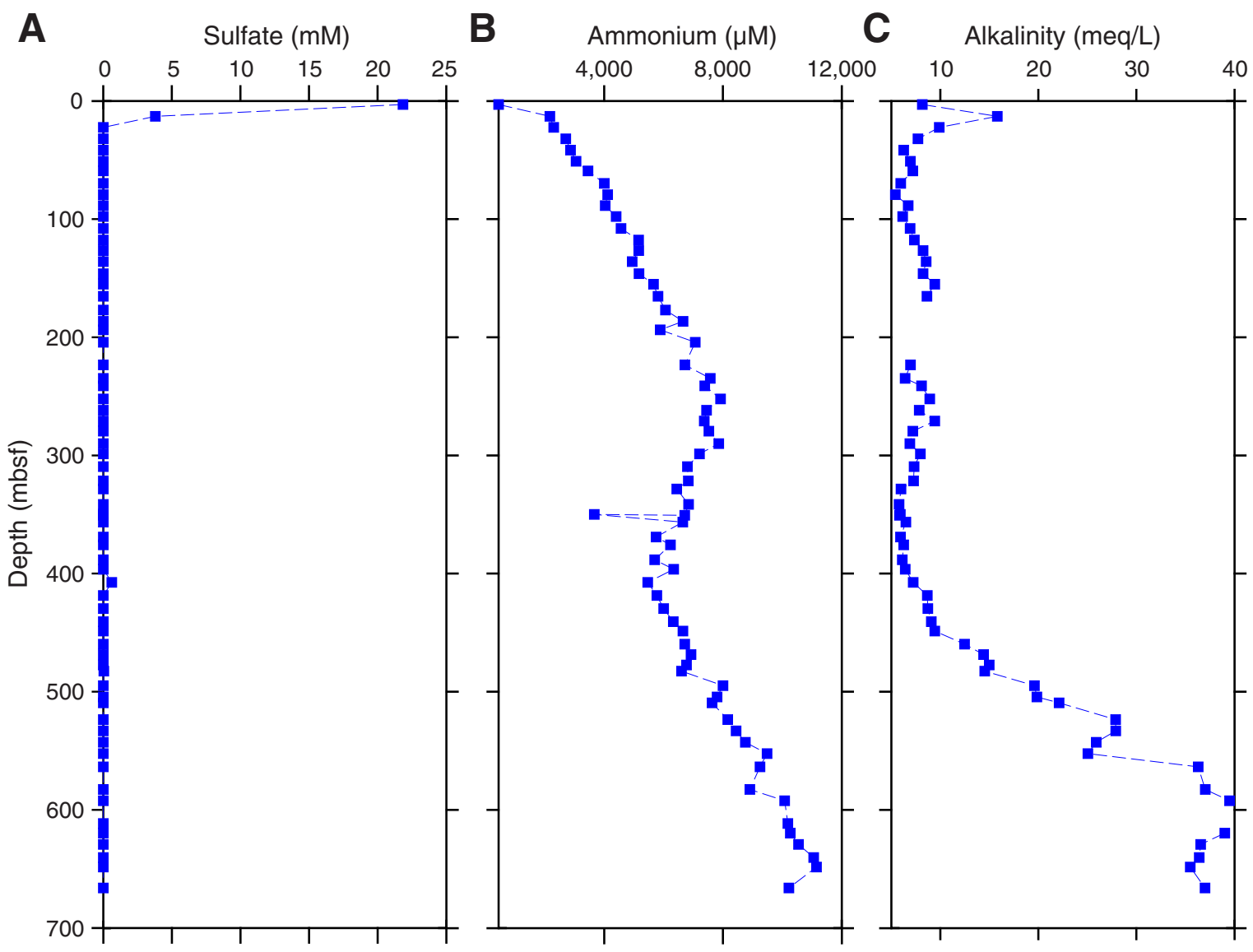


Figure F28. A-C. Plots of interstitial water calcium, magnesium, and potassium, Site U1391.

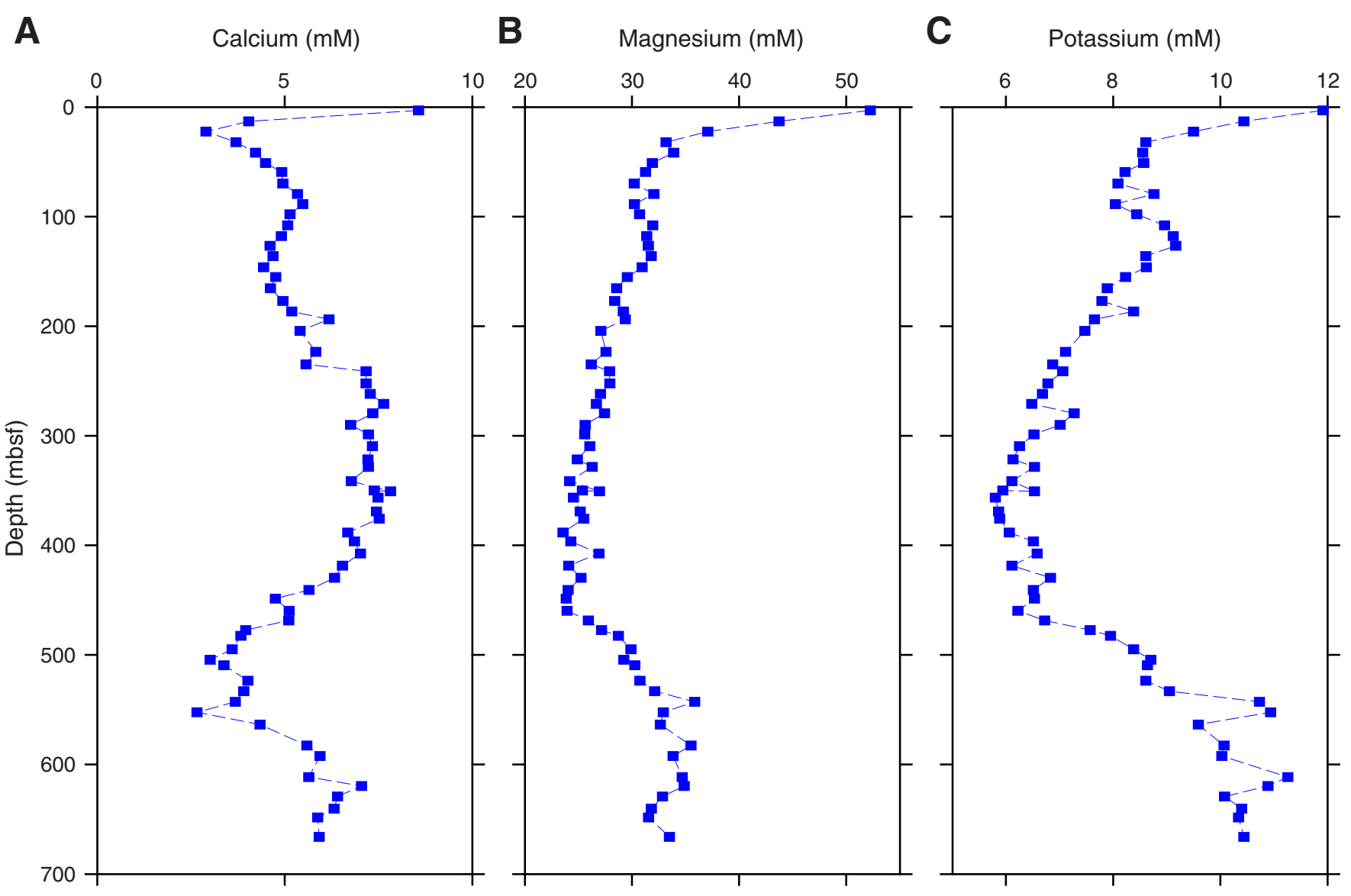


Figure F29. A-C. Plots of interstitial water chloride, sodium, and $\mathrm{Na}^{+} / \mathrm{Cl}^{-}$ratio, Site U1391.

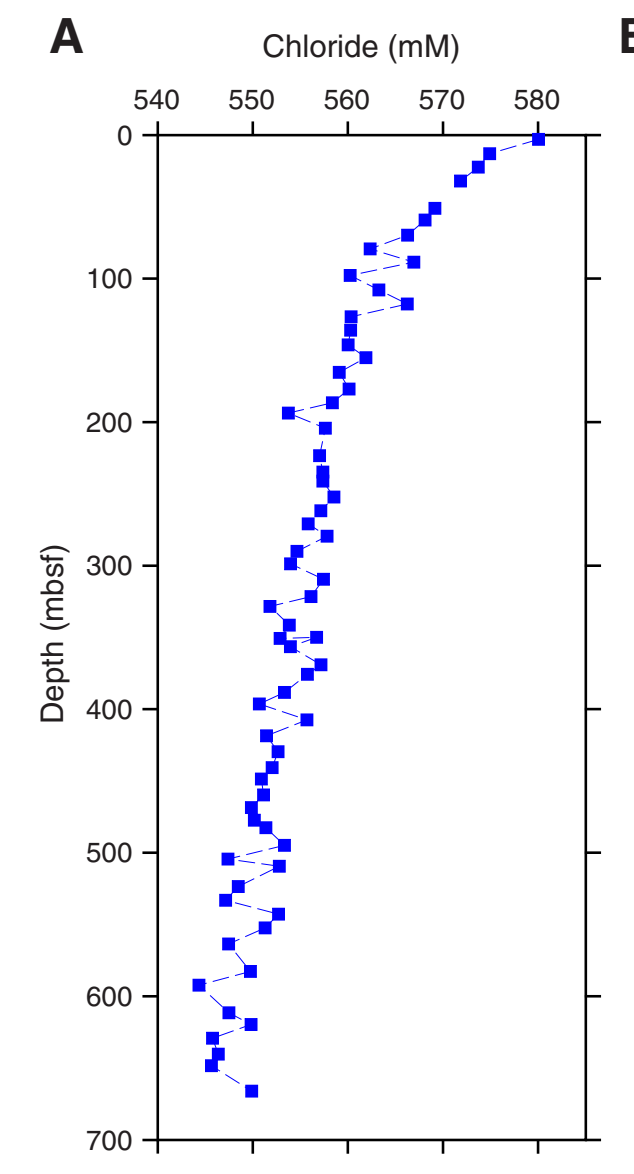

B Sodium (mM)

C $\quad \mathrm{Na}^{+} / \mathrm{Cl}^{-}$
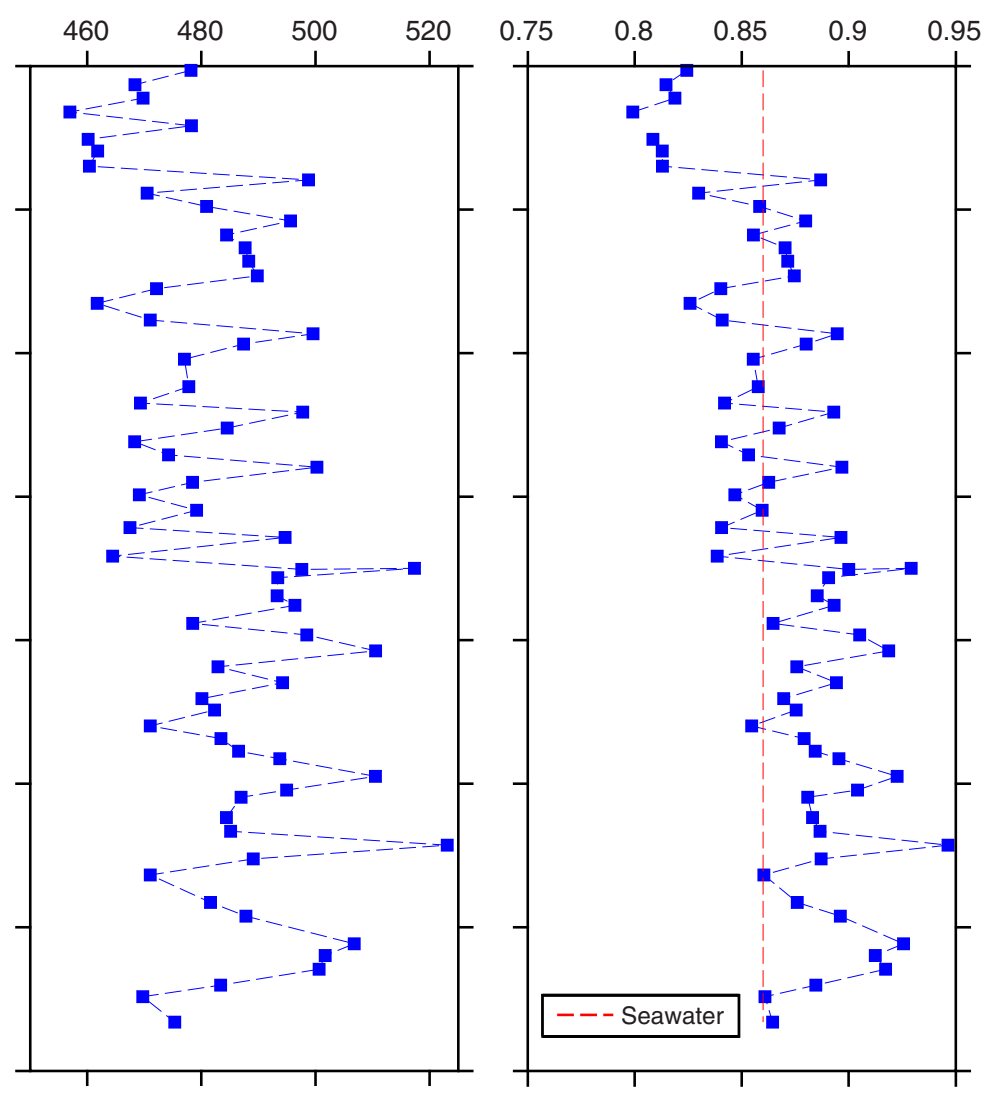
Figure F30. A-C. Plots of interstitial water barium, boron, and iron, Site U1391.

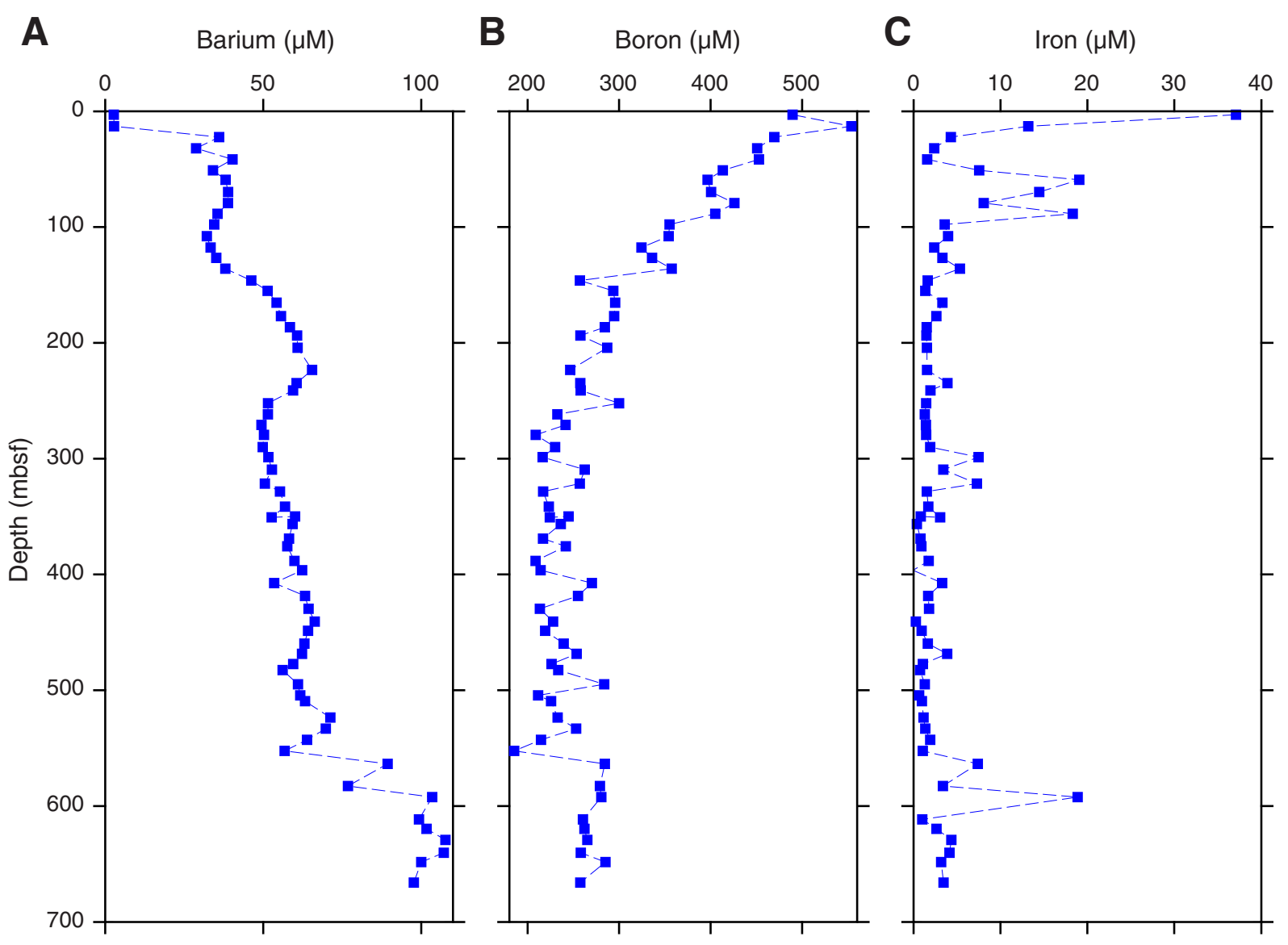


Figure F31. A-C. Plots of interstitial water lithium, silicon, and strontium, Site U1391.

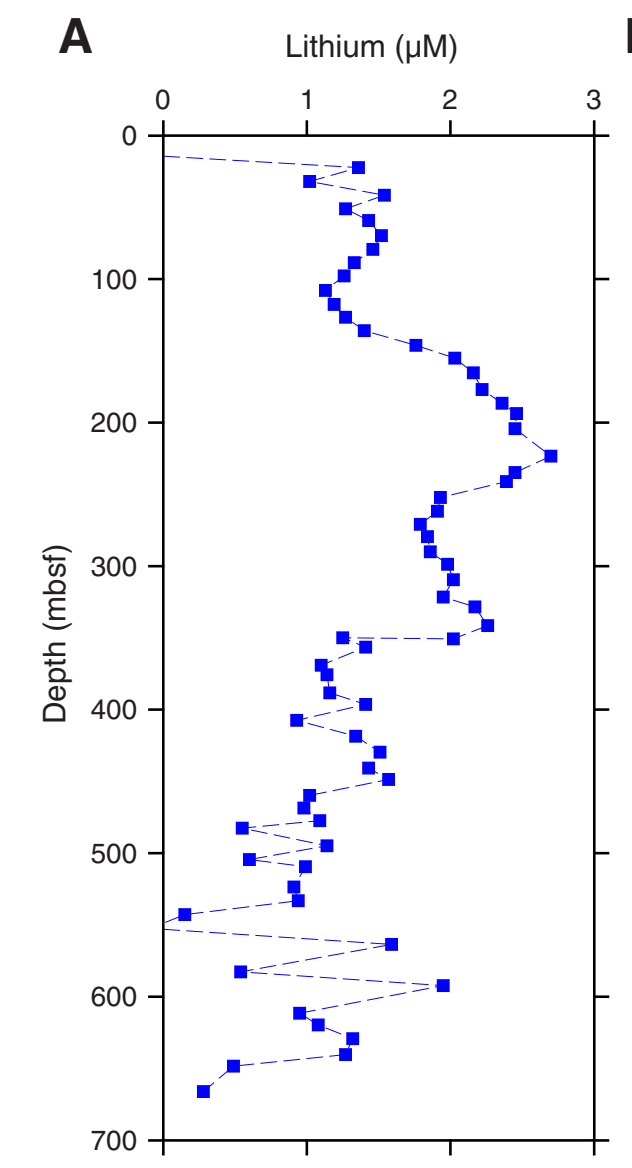

B Silicon $(\mu \mathrm{M})$

C Strontium $(\mu \mathrm{M})$
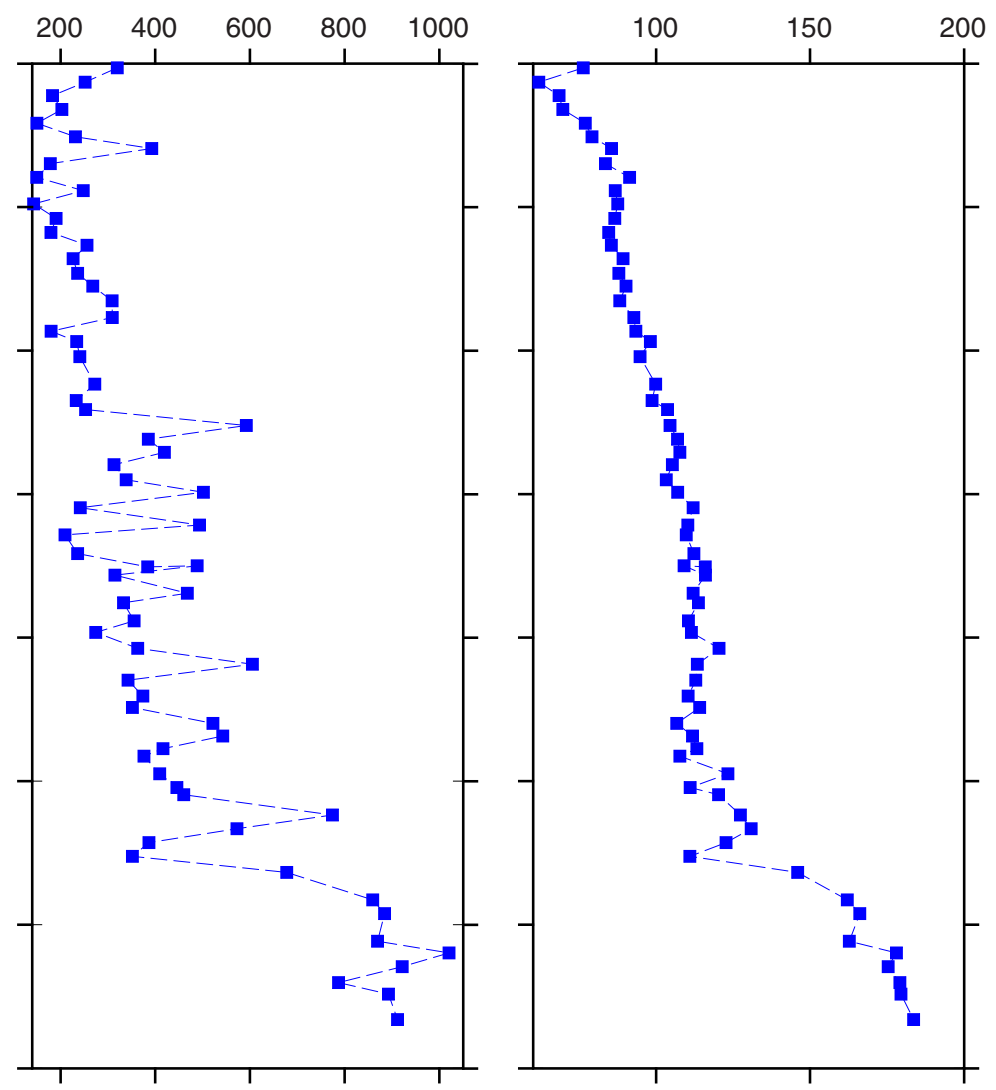
Figure F32. Plots of interstitial water stable isotopes, Site U1391. VSMOW = Vienna standard mean ocean water.

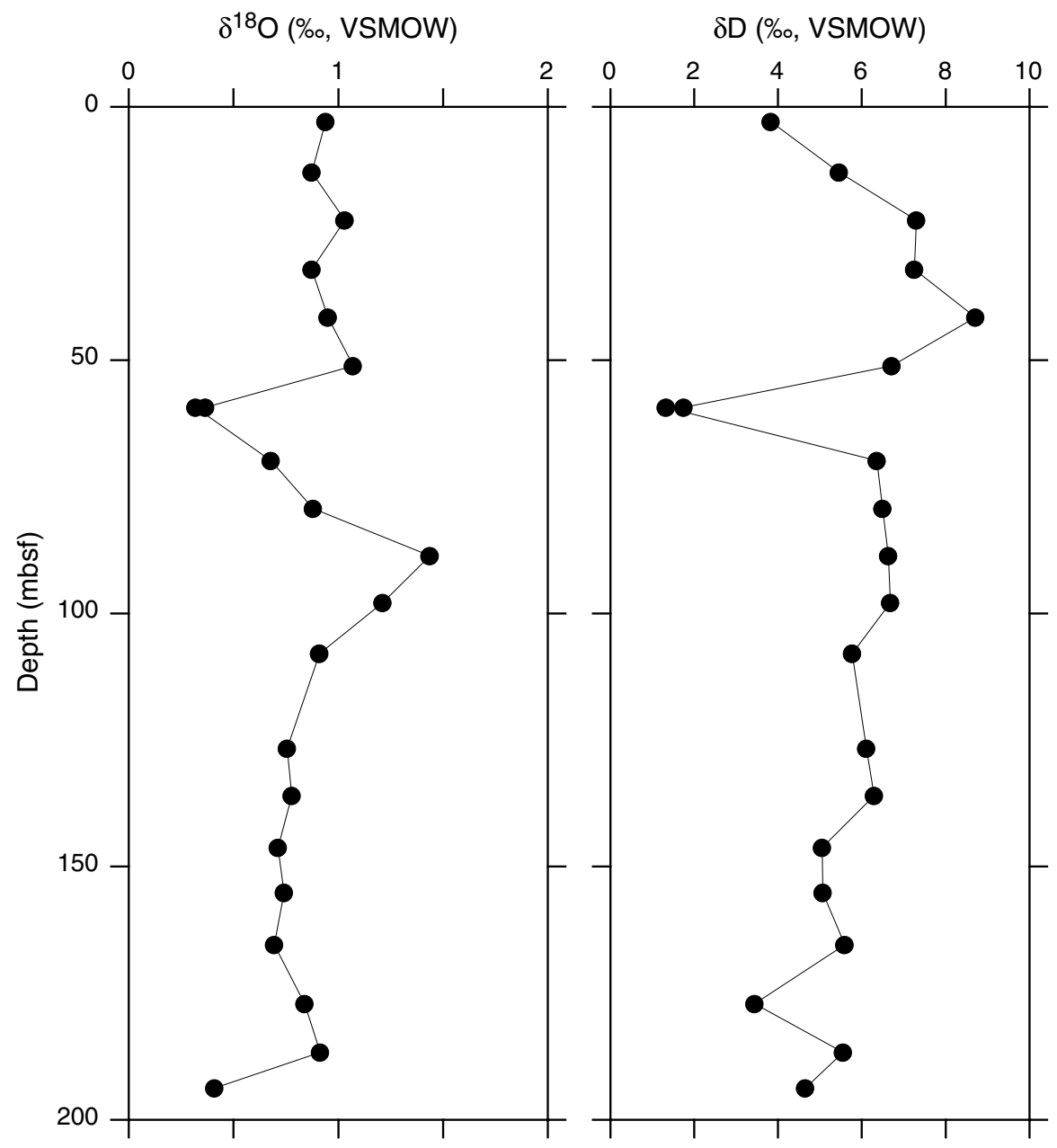


Figure F33. Plot of $\delta^{18} \mathrm{O}$ vs. $\delta \mathrm{D}$, Site U1391. VSMOW = Vienna standard mean ocean water.

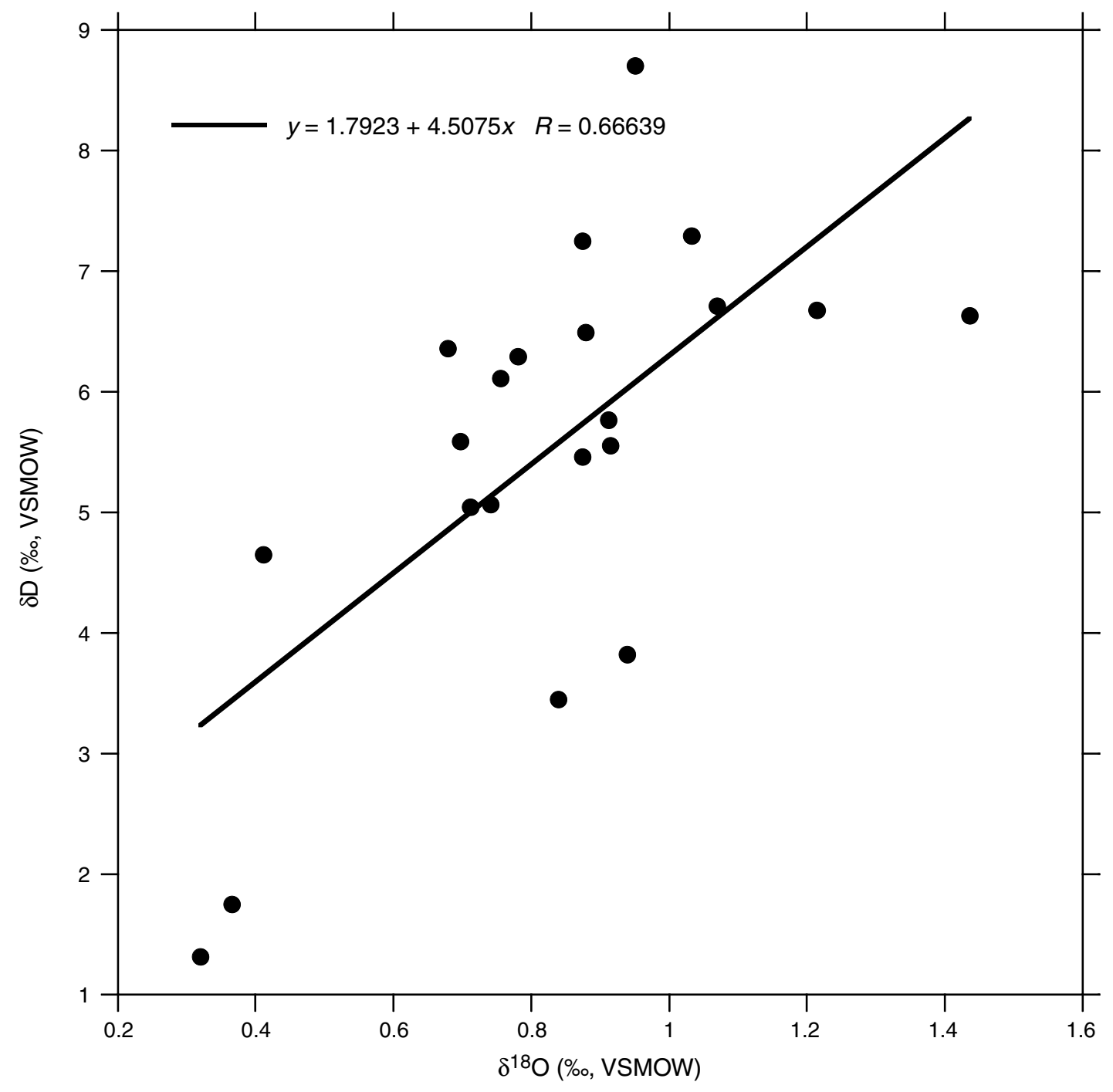


Figure F34. Logging operations summary diagram, Hole U1391C. FMS = Formation MicroScanner.

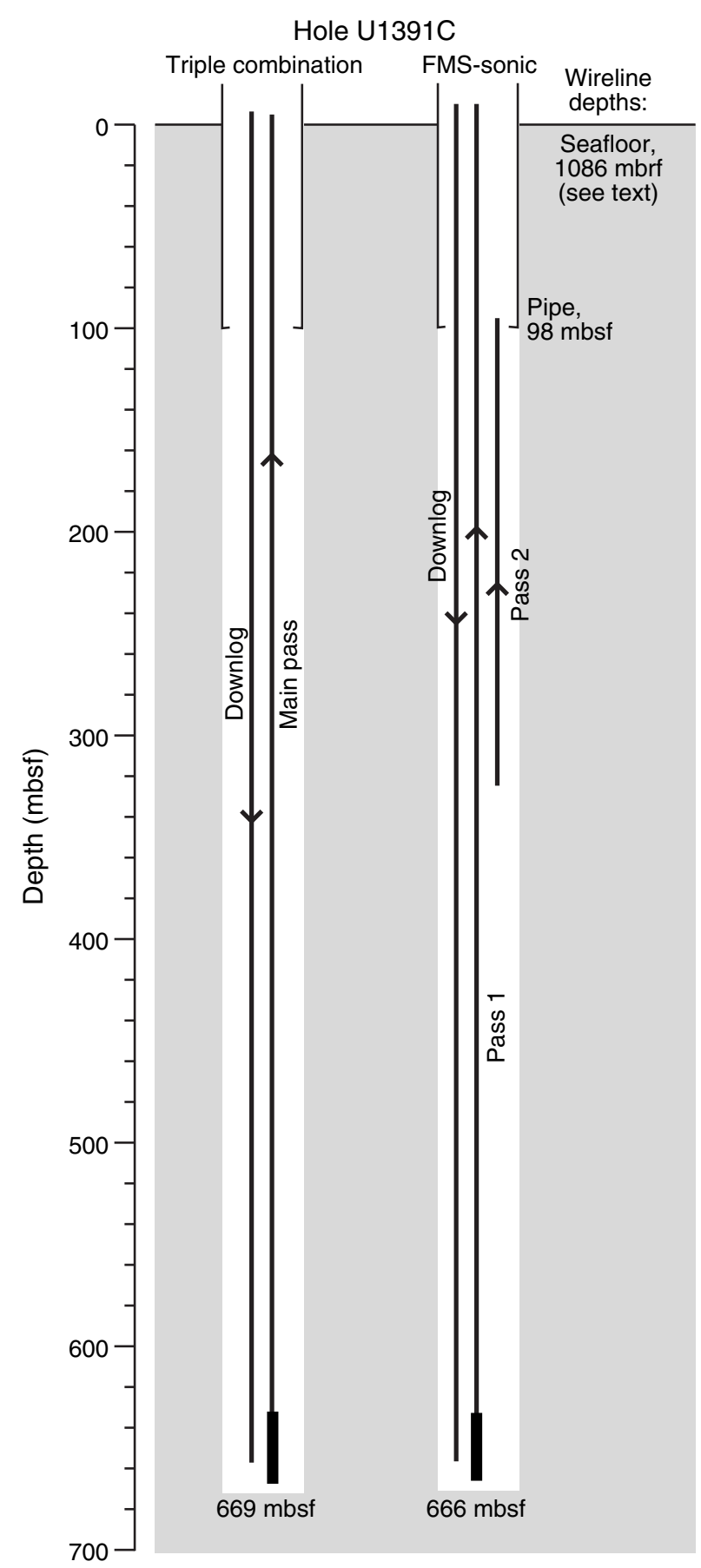


Figure F35. Plots of tides and ship heave, Site U1391. Tides were calculated using Tide Model Driver, a Matlab front-end for the Oregon State University Tidal Data Inversion (Egbert and Erofeeva, 2002). Ship heave was derived from acceleration measured by the motion reference unit in the moon pool area. FMS = Formation MicroScanner, APCT-3 = advanced piston corer temperature tool. RMS = root-mean square.

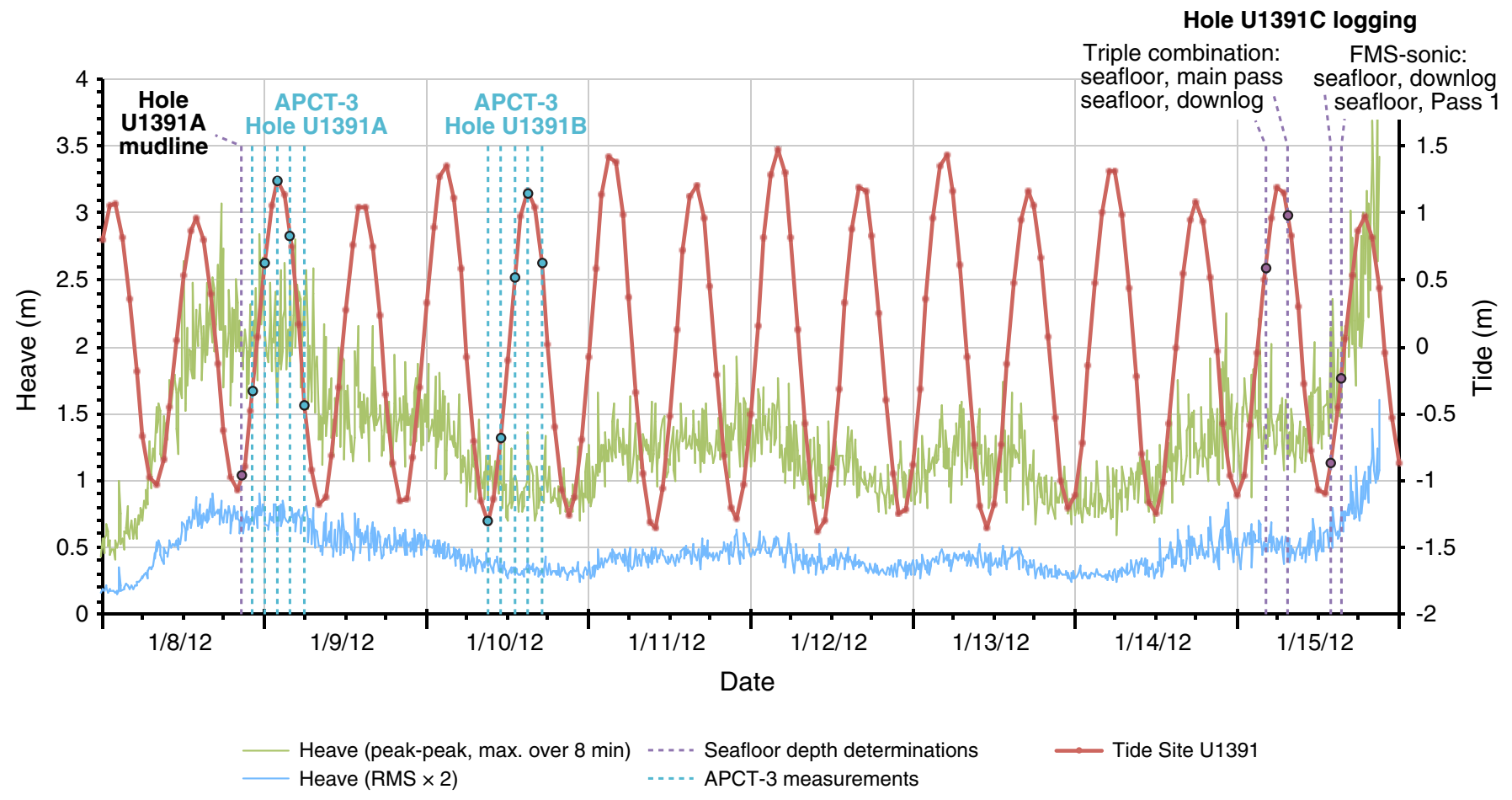


Figure F36. Downhole logs, lithologic units, and logging units, Hole U1391C. HSGR = standard (total) gamma radiation, NGR = natural gamma radiation, $\mathrm{MAD}=$ moisture and density, $\mathrm{RHOM}=$ bulk density, RLA5 = apparent resistivity from computed focusing mode $5, \mathrm{PWL}=P$-wave logger.

Hole U1391C

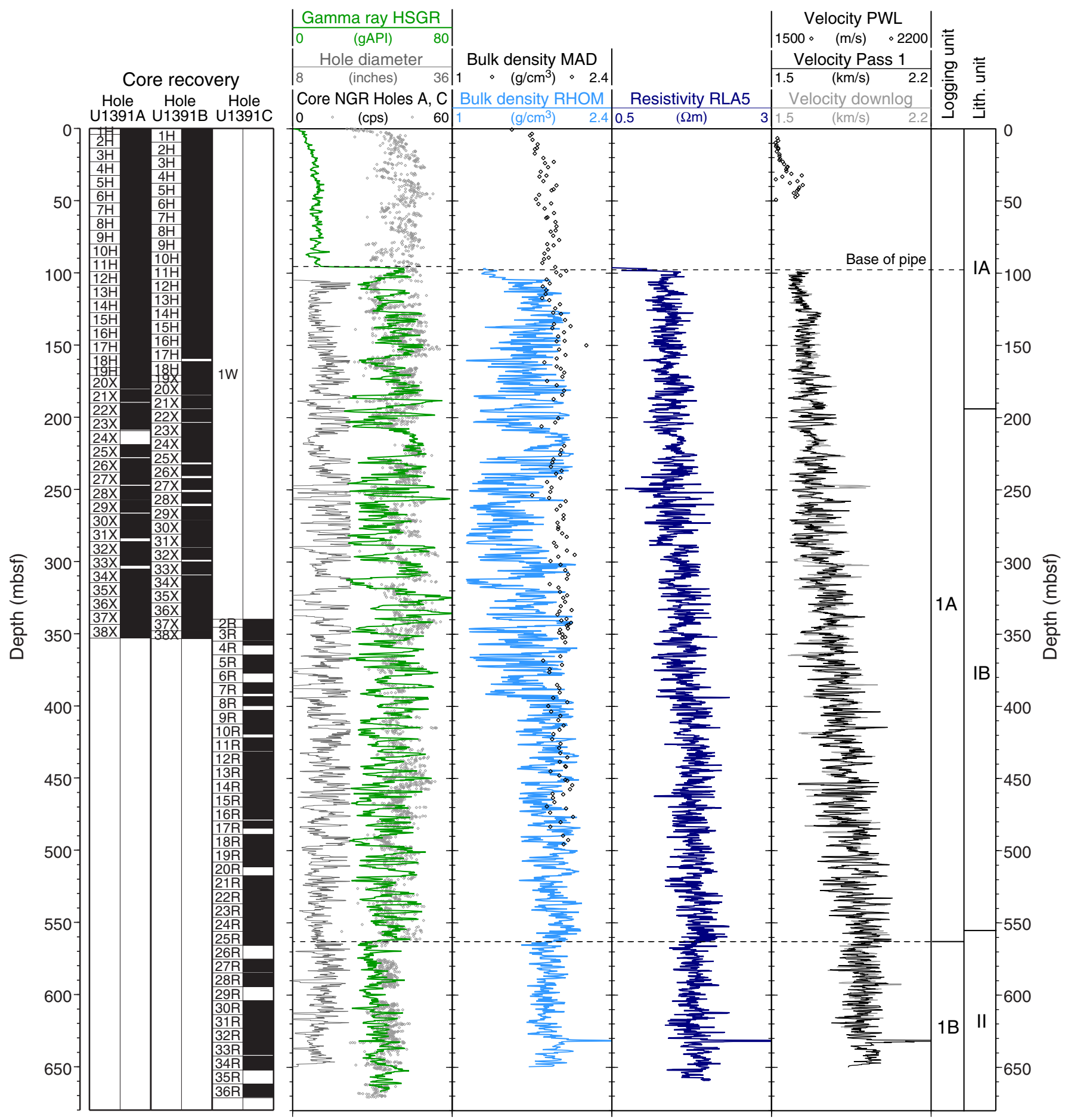


Figure F37. Natural gamma radiation (NGR) logs, lithologic units, and logging units, Hole U1391C. HSGR = standard (total) gamma radiation.

Hole U1391C

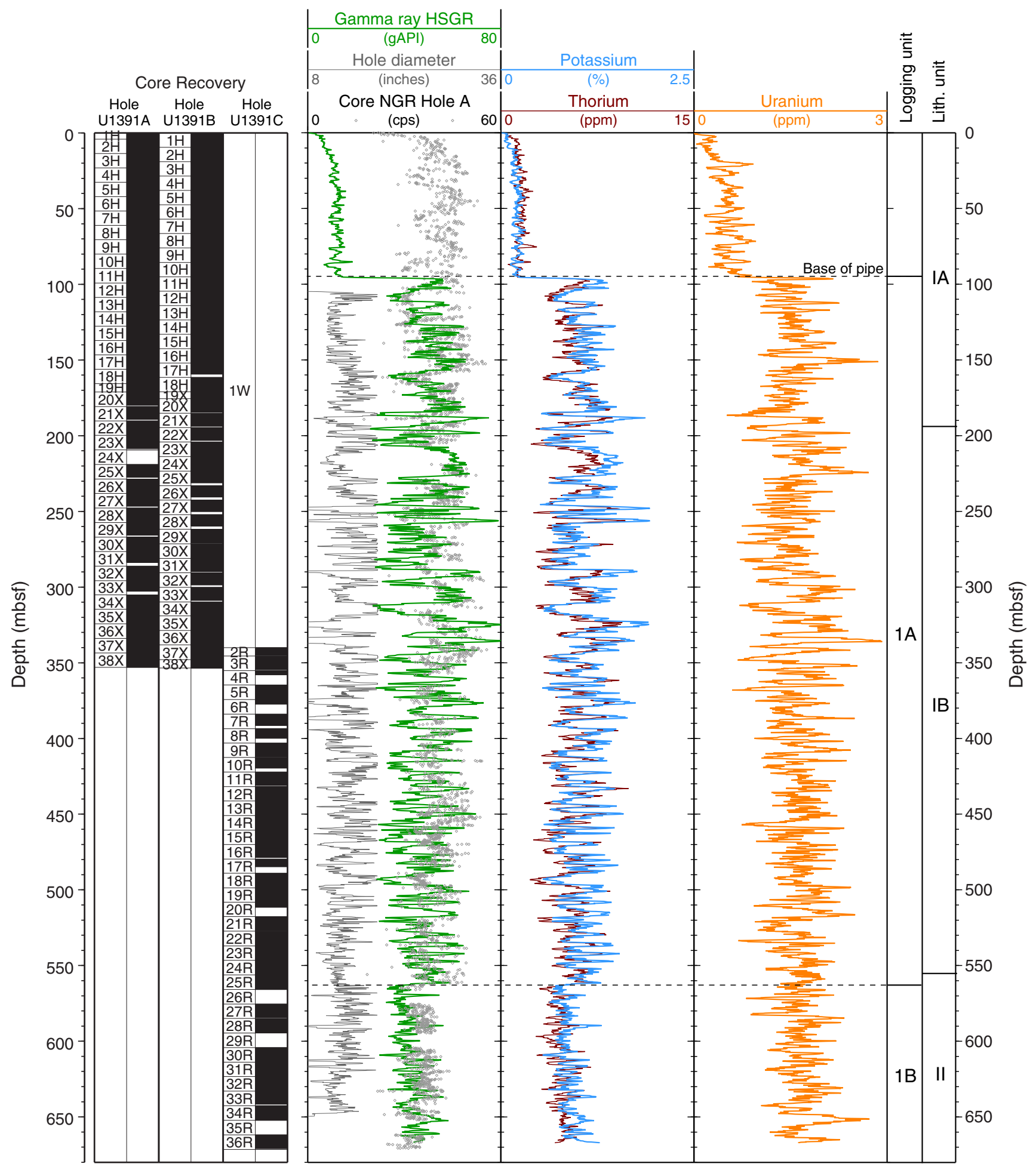


Figure F38. Plot of advanced piston corer temperature tool (APCT-3) temperature-time series with extrapolated formation temperature estimates, Site U1391. APC = advanced piston corer.

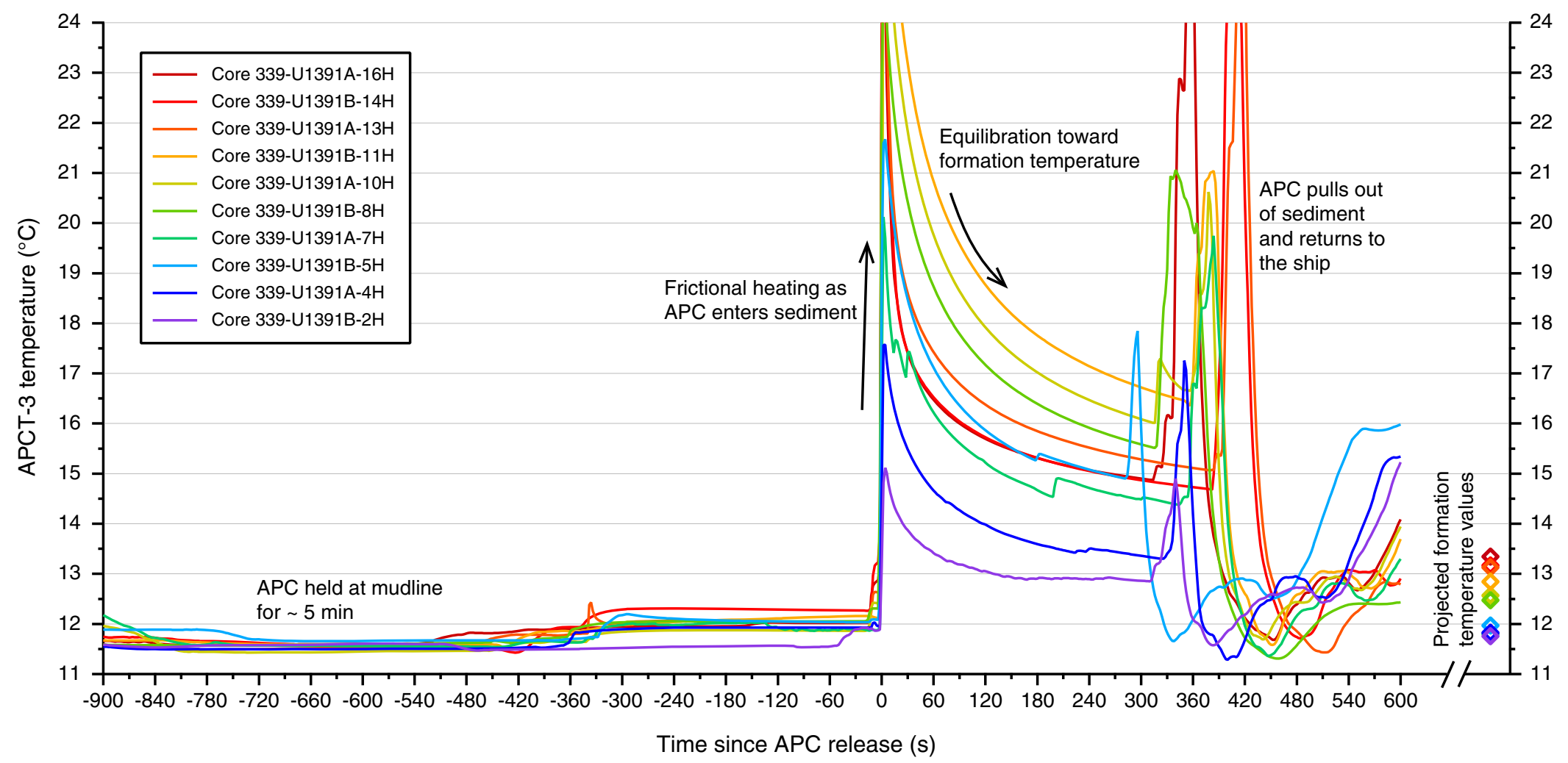


Figure F39. Plots of heat flow calculations, Site U1391. A. Sediment temperatures in Holes U1391A and U1391B (squares). B. Thermal conductivity data from Hole U1391C (circles) with calculated thermal resistance (solid line). C. Bullard plot of heat flow calculated from a linear fit of the temperature data.

A APCT-3 temperature $\left({ }^{\circ} \mathrm{C}\right)$

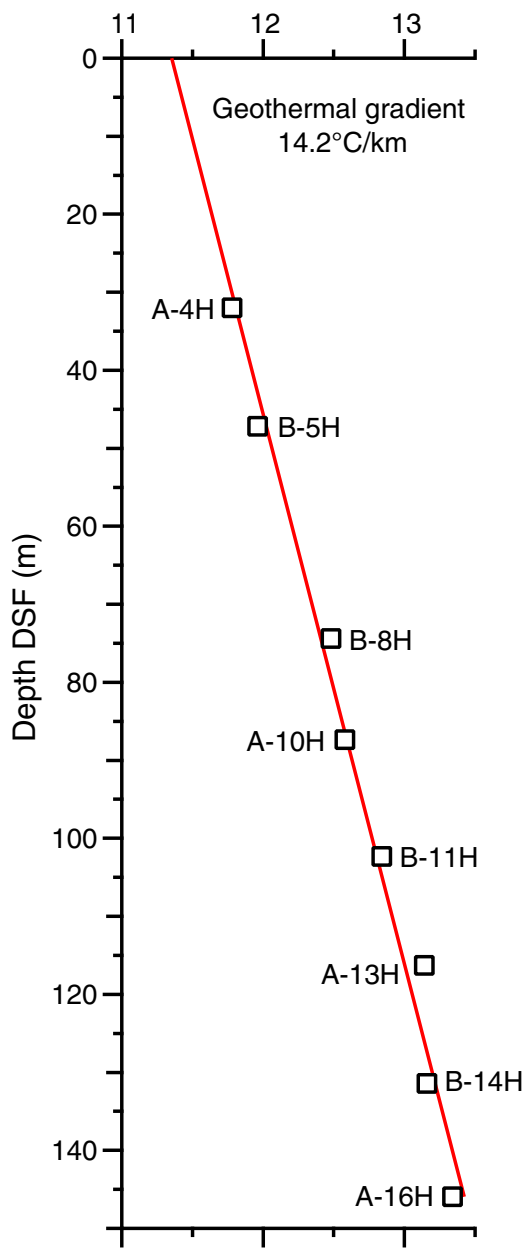

B Thermal conductivity $(\mathrm{W} /[\mathrm{m} \cdot \mathrm{K}])$

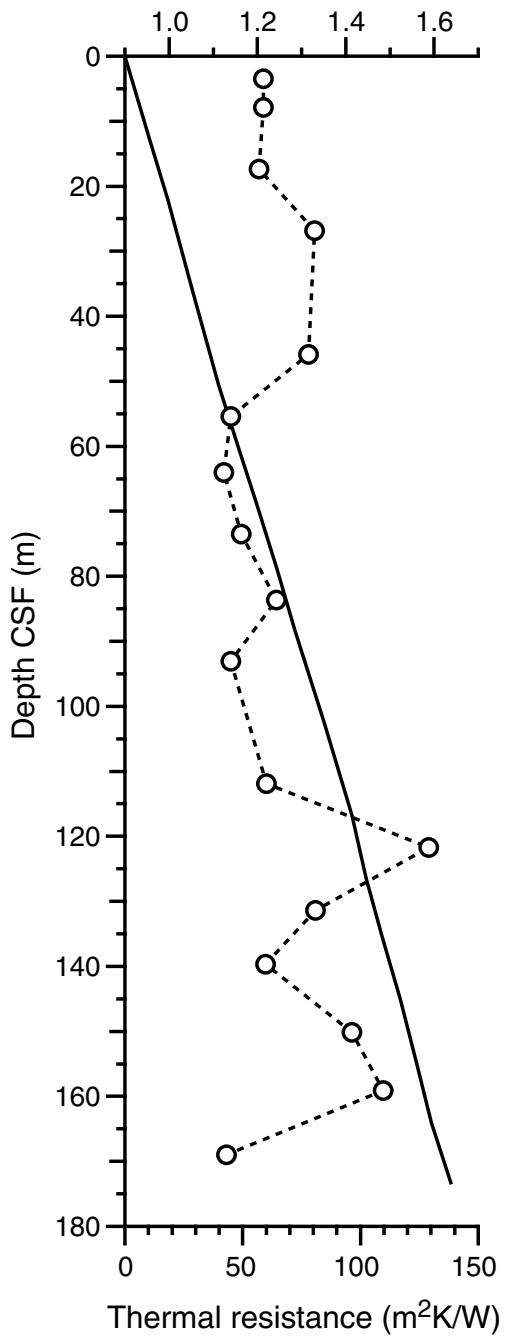

C APCT-3 temperature $\left({ }^{\circ} \mathrm{C}\right)$
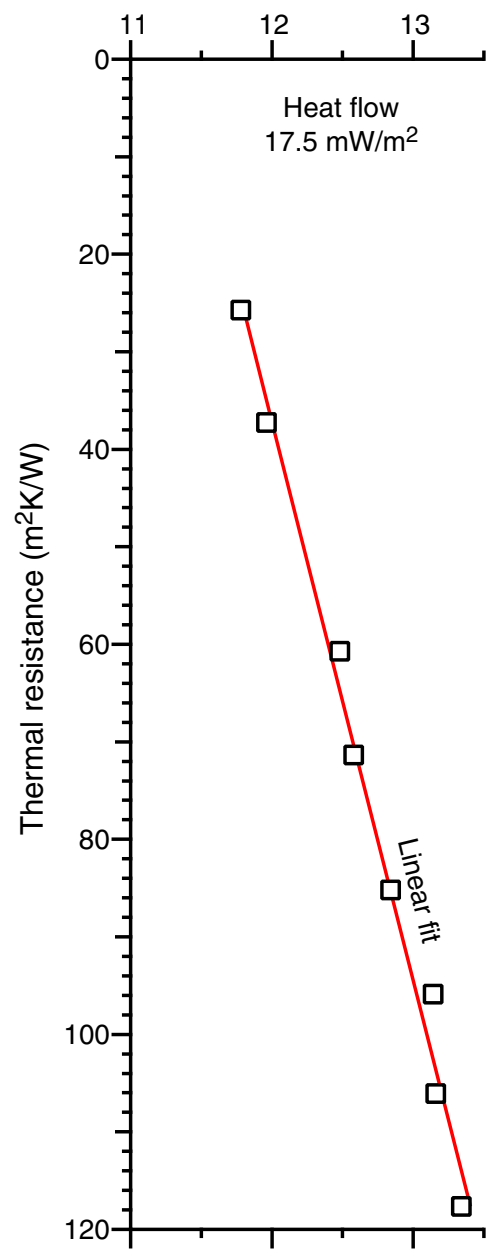
Figure F40. Plots of magnetic susceptibility vs. composite depth, Site U1391. In the lower panel, susceptibility values for Holes U1391B and U1391C are shifted for display purposes. A. 0-40 mcd. (Continued on next 10 pages.)
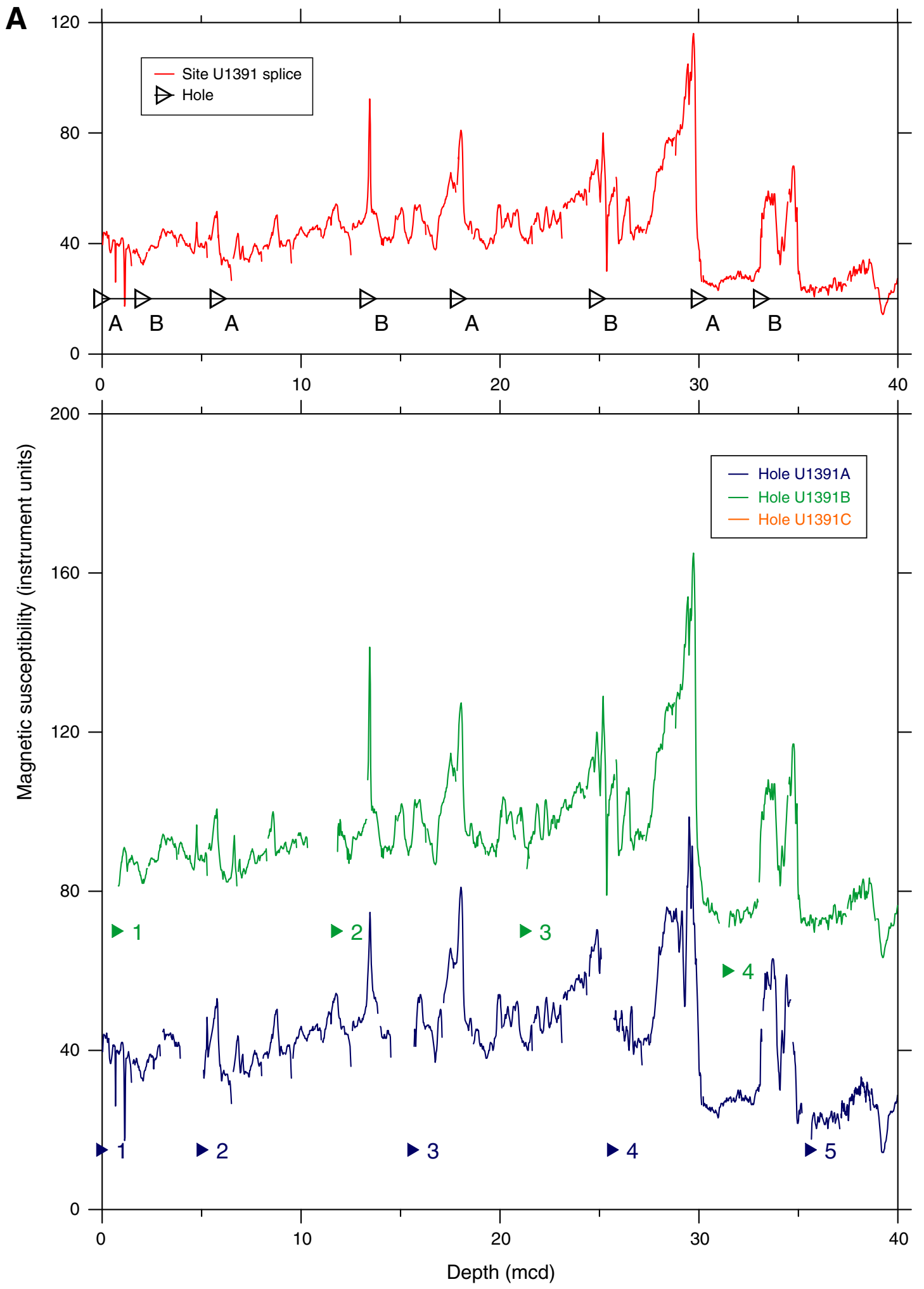
Figure F40 (continued). B. $40-80$ mcd. (Continued on next page.)
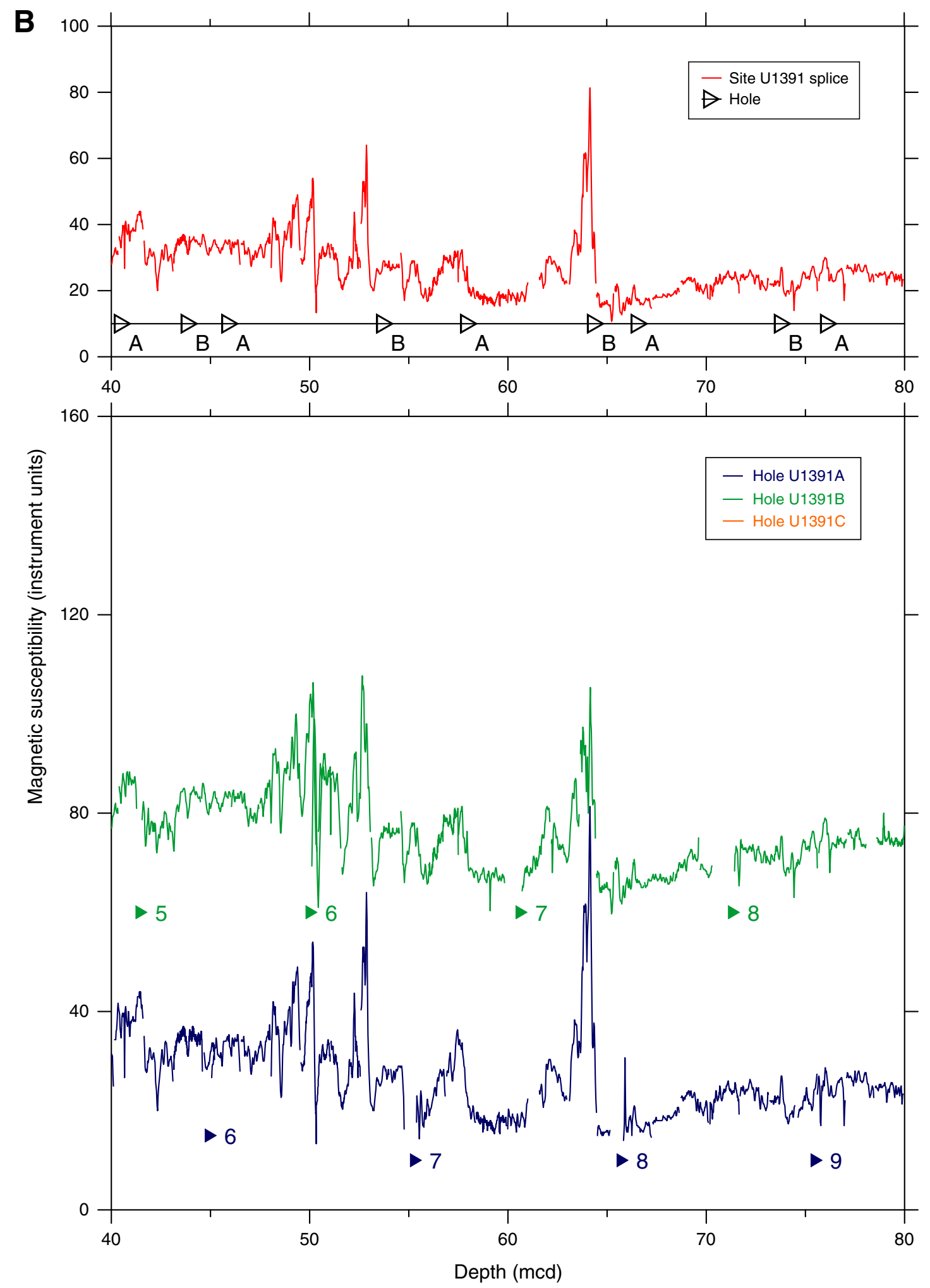
Figure F40 (continued). C. 80-120 mcd. (Continued on next page.)
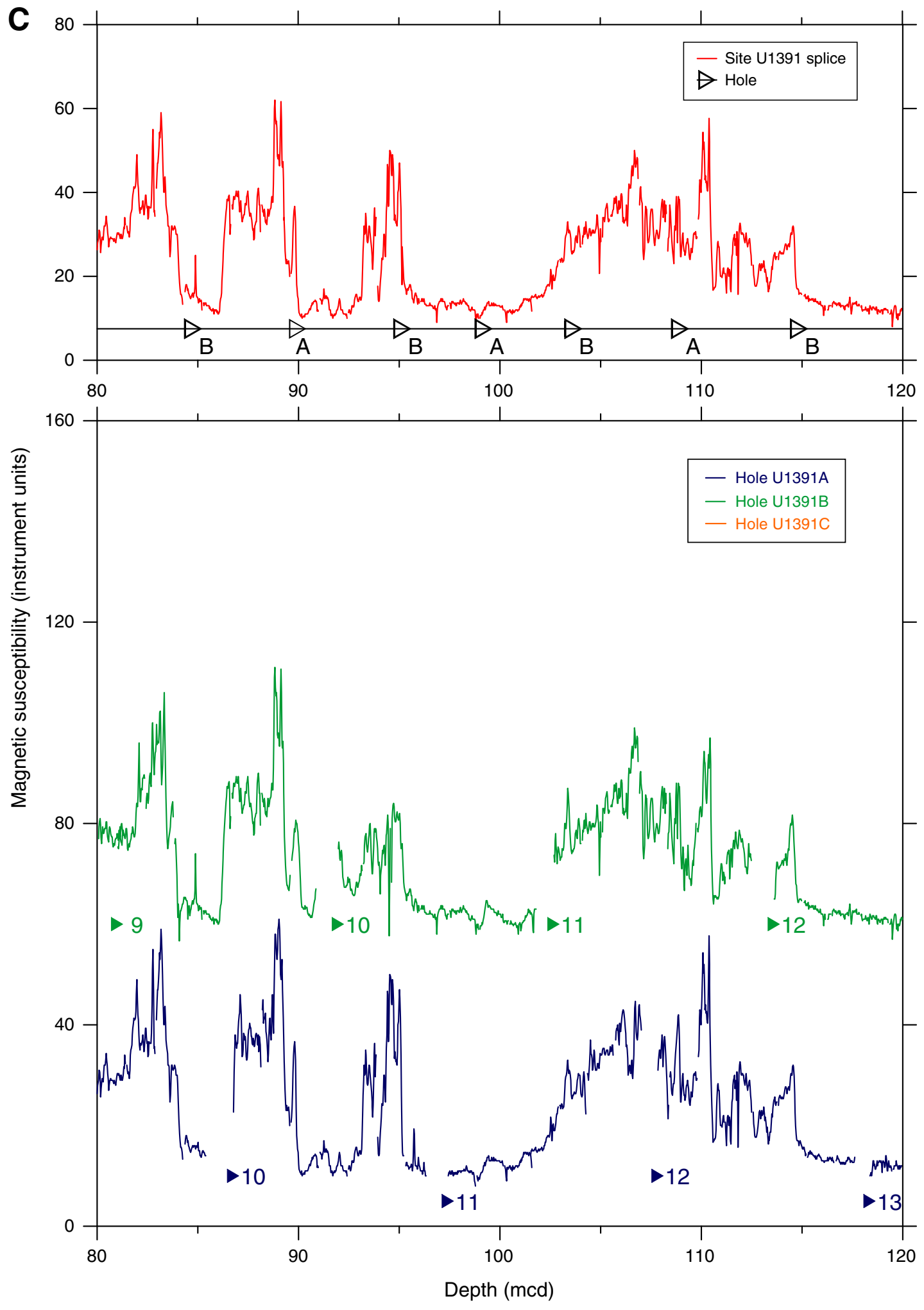
Figure F40 (continued). D. 120-160 mcd. (Continued on next page.)
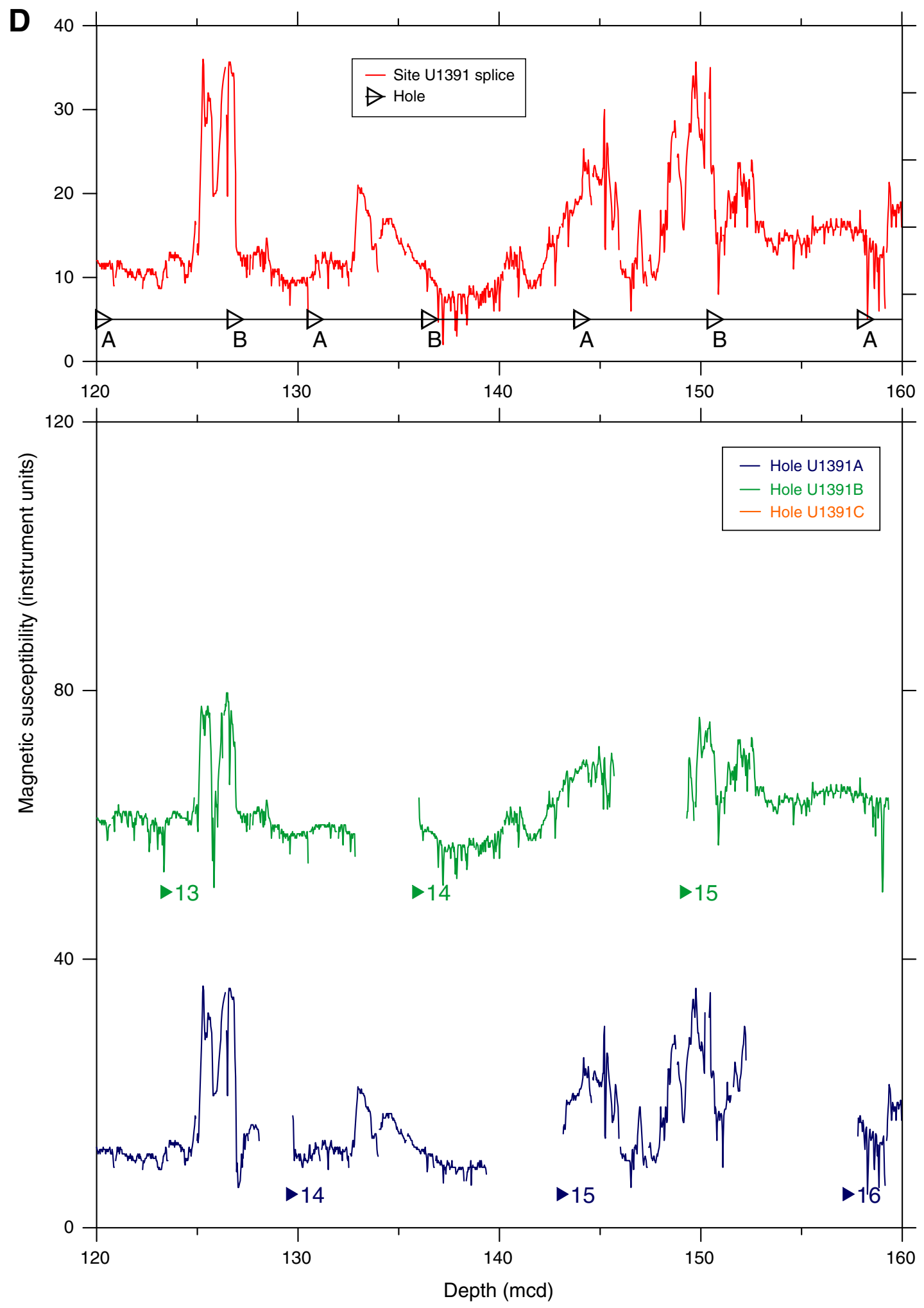
Figure F40 (continued). E. 160-200 mcd. (Continued on next page.)
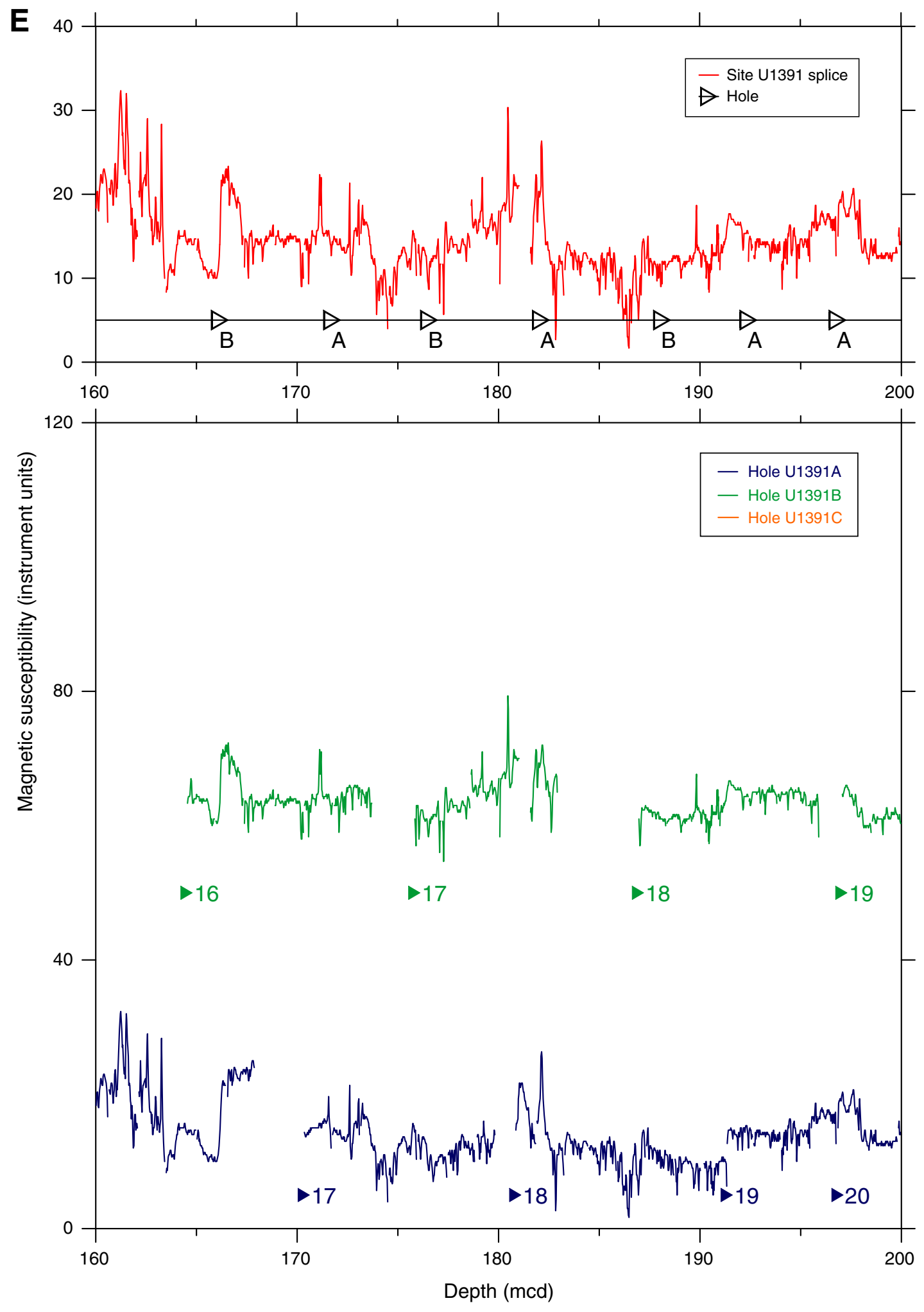
Figure F40 (continued). F. 200-240 mcd. (Continued on next page.)

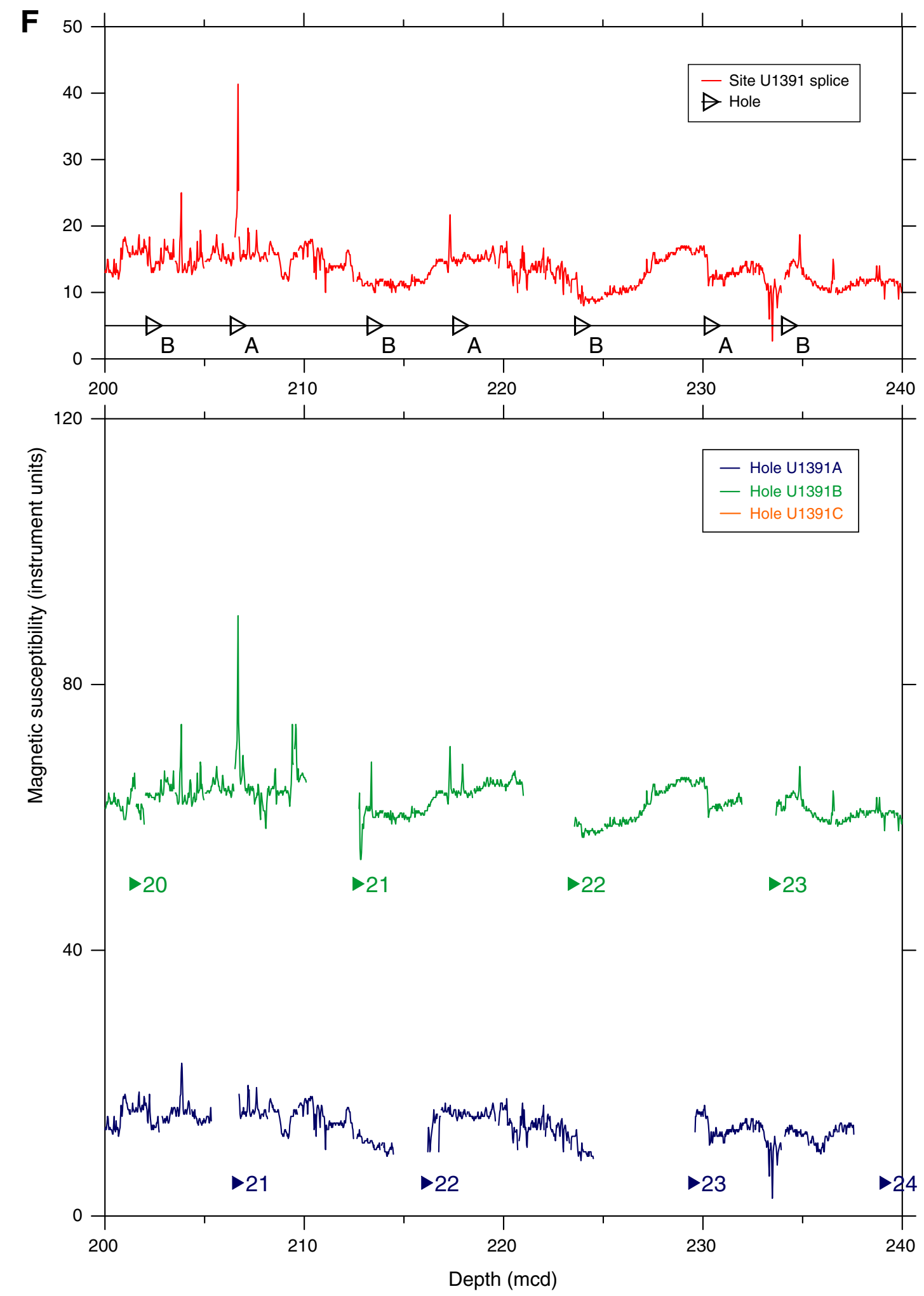


Figure F40 (continued). G. 240-280 mcd. (Continued on next page.)
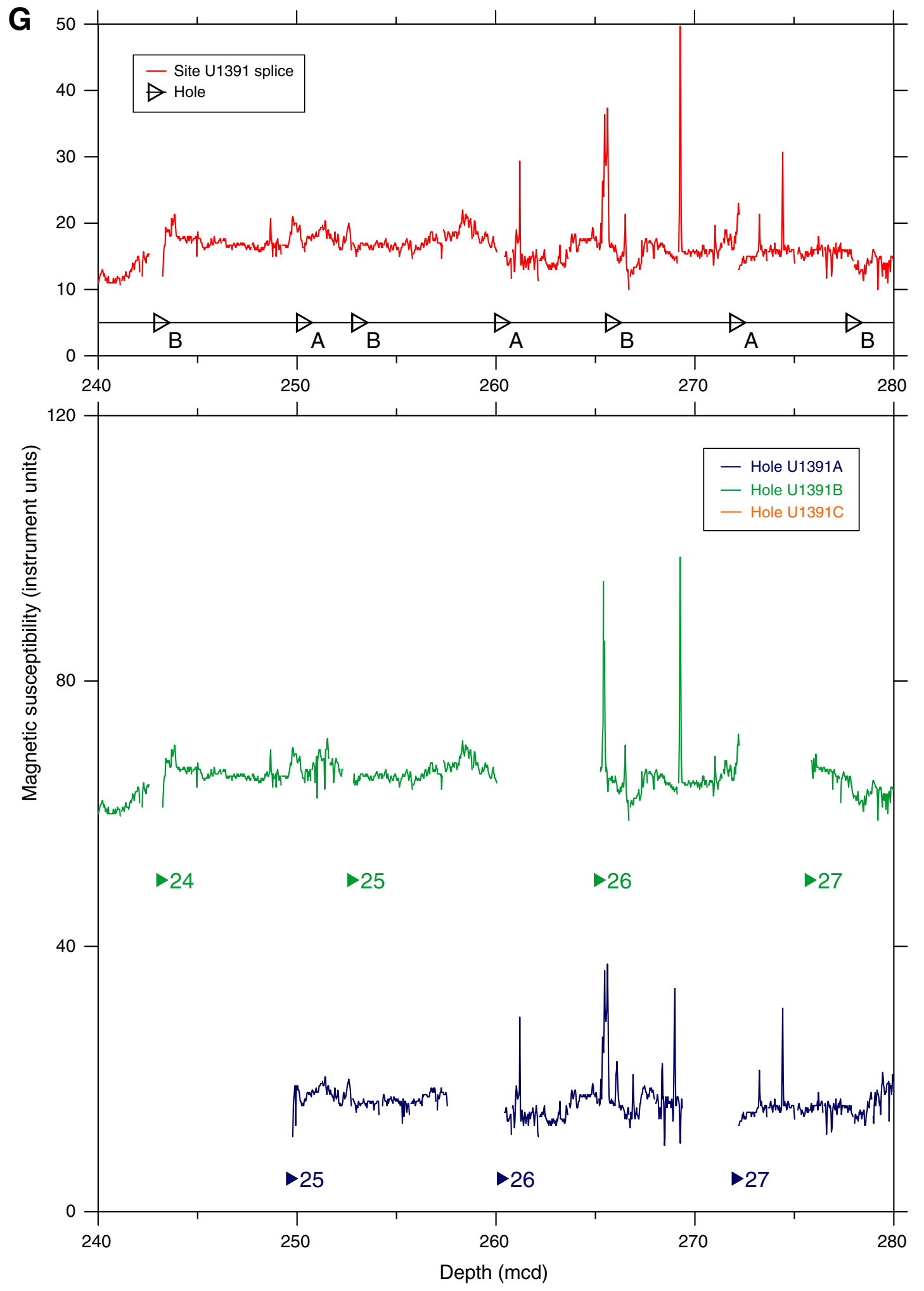
Figure F40 (continued). H. 280-320 mcd. (Continued on next page.)

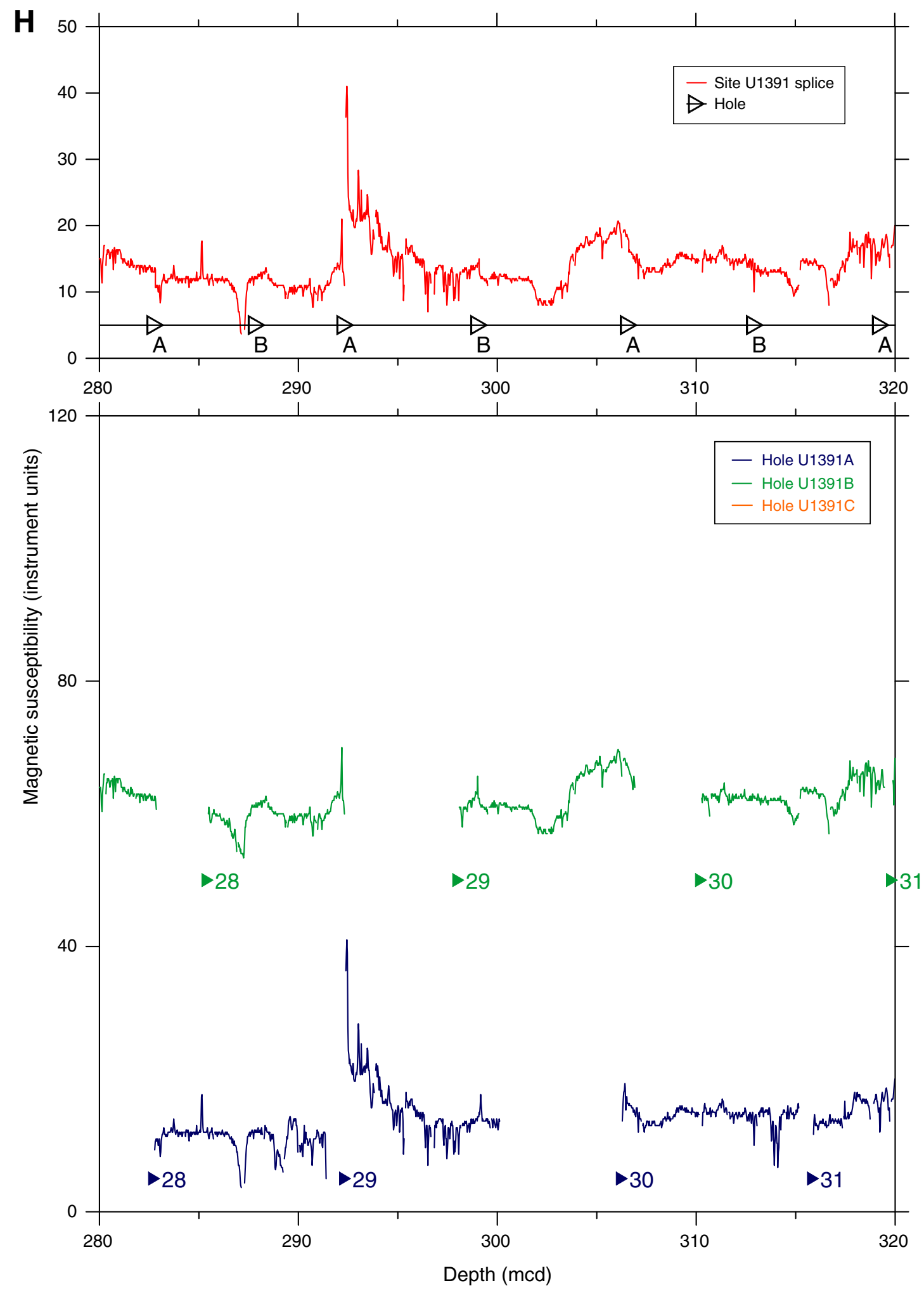


Figure F40 (continued). I. 320-360 mcd. (Continued on next page.)
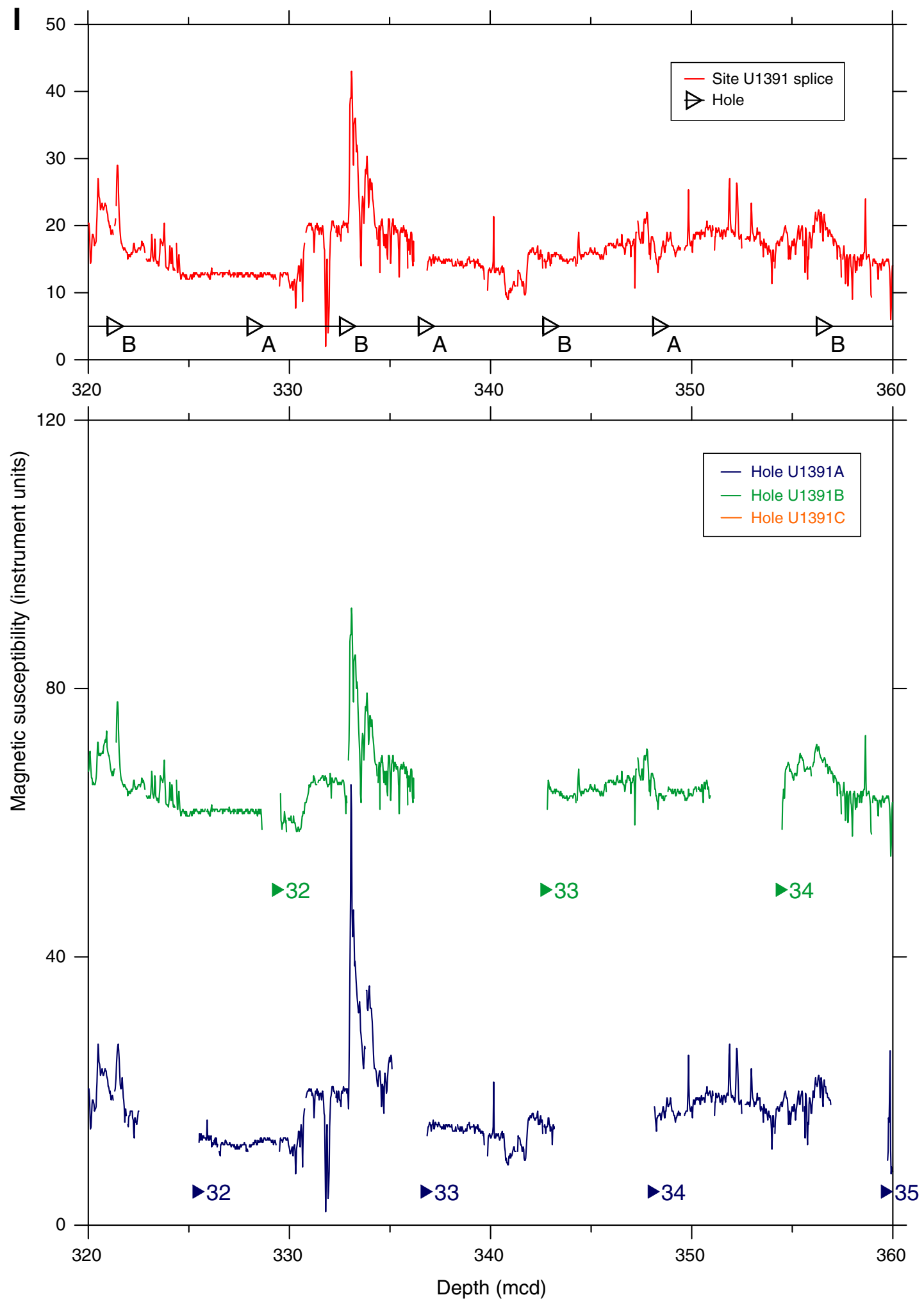
Figure F40 (continued). J. 360-400 mcd. (Continued on next page.)

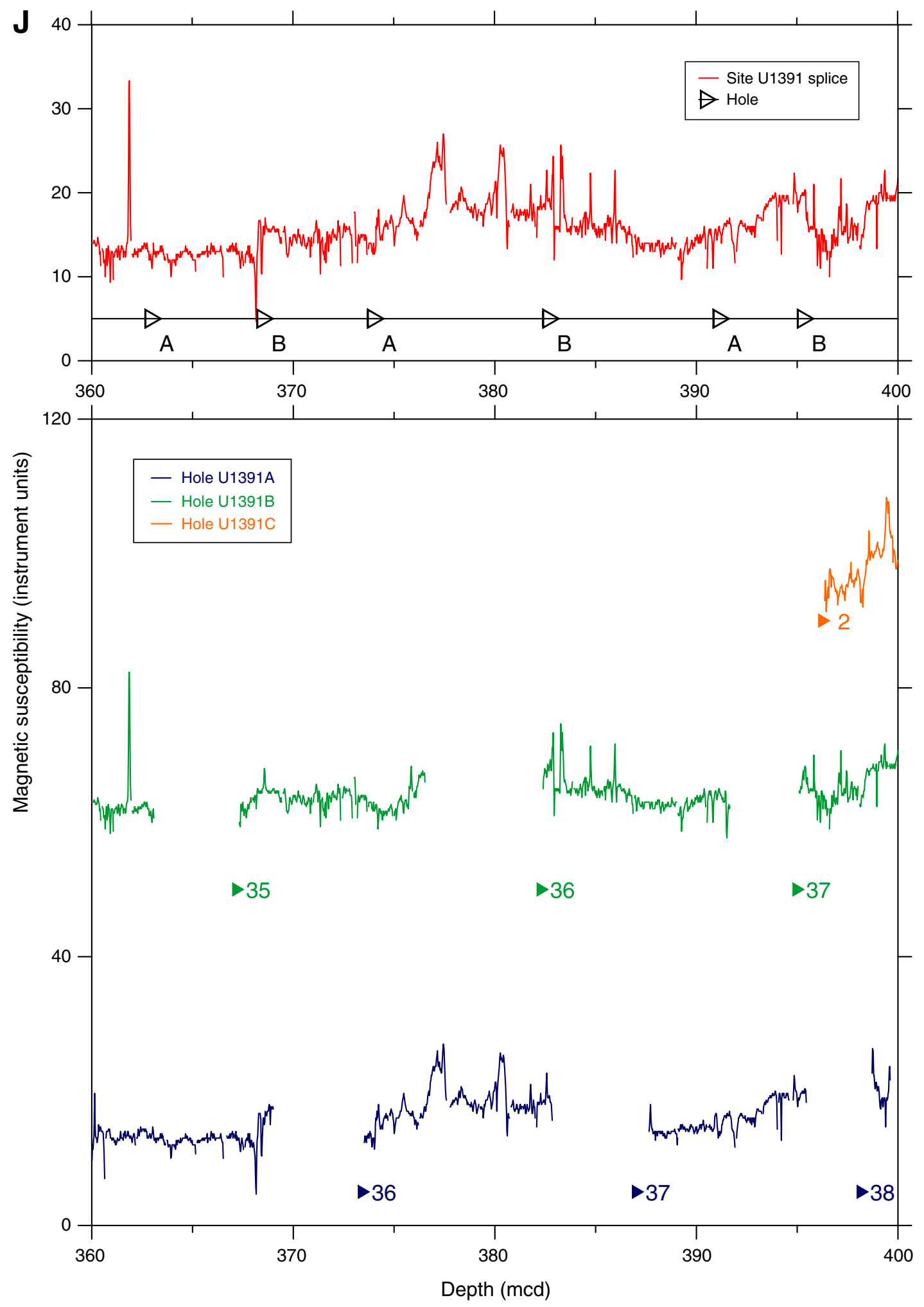


Figure F40 (continued). K. 400-440 mcd.
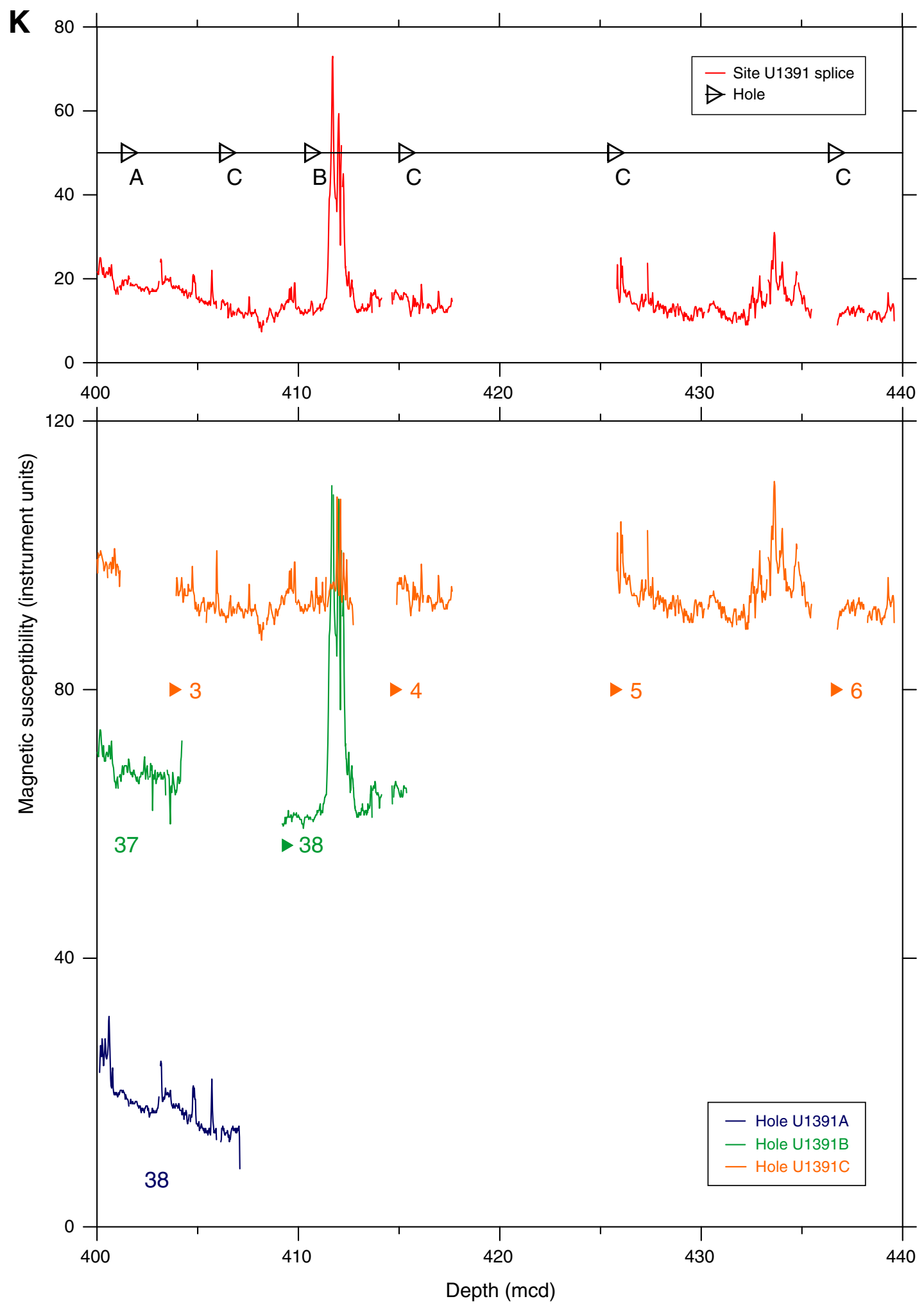
Figure F41. Plot of Site U1391 core top depths for mbsf vs. mcd. The slope of the best-fit line through the core top depths, which is 1.144, gives an estimate of the average amount the mcd scale is expanded relative to the mbsf scales of the three holes.

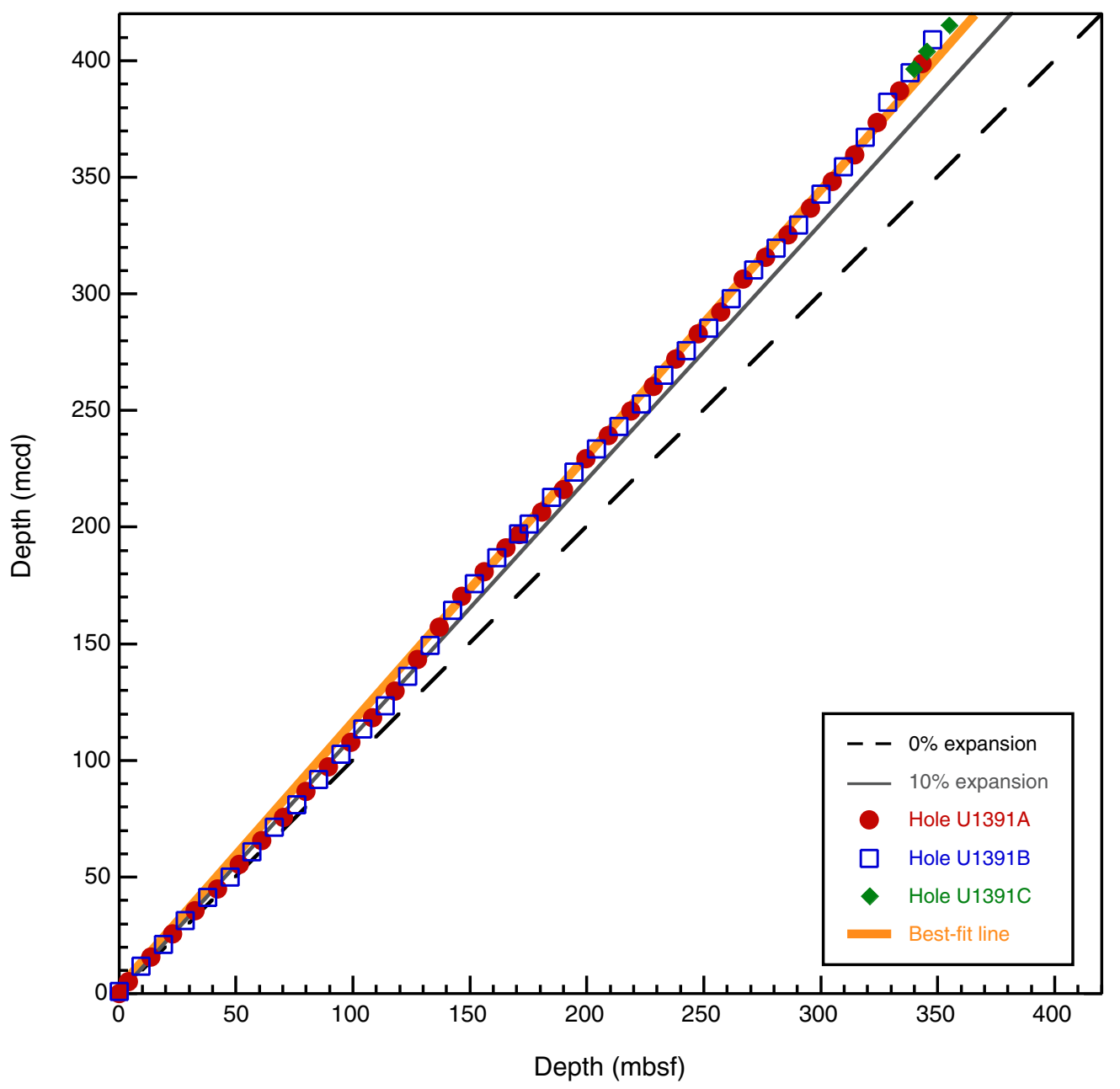



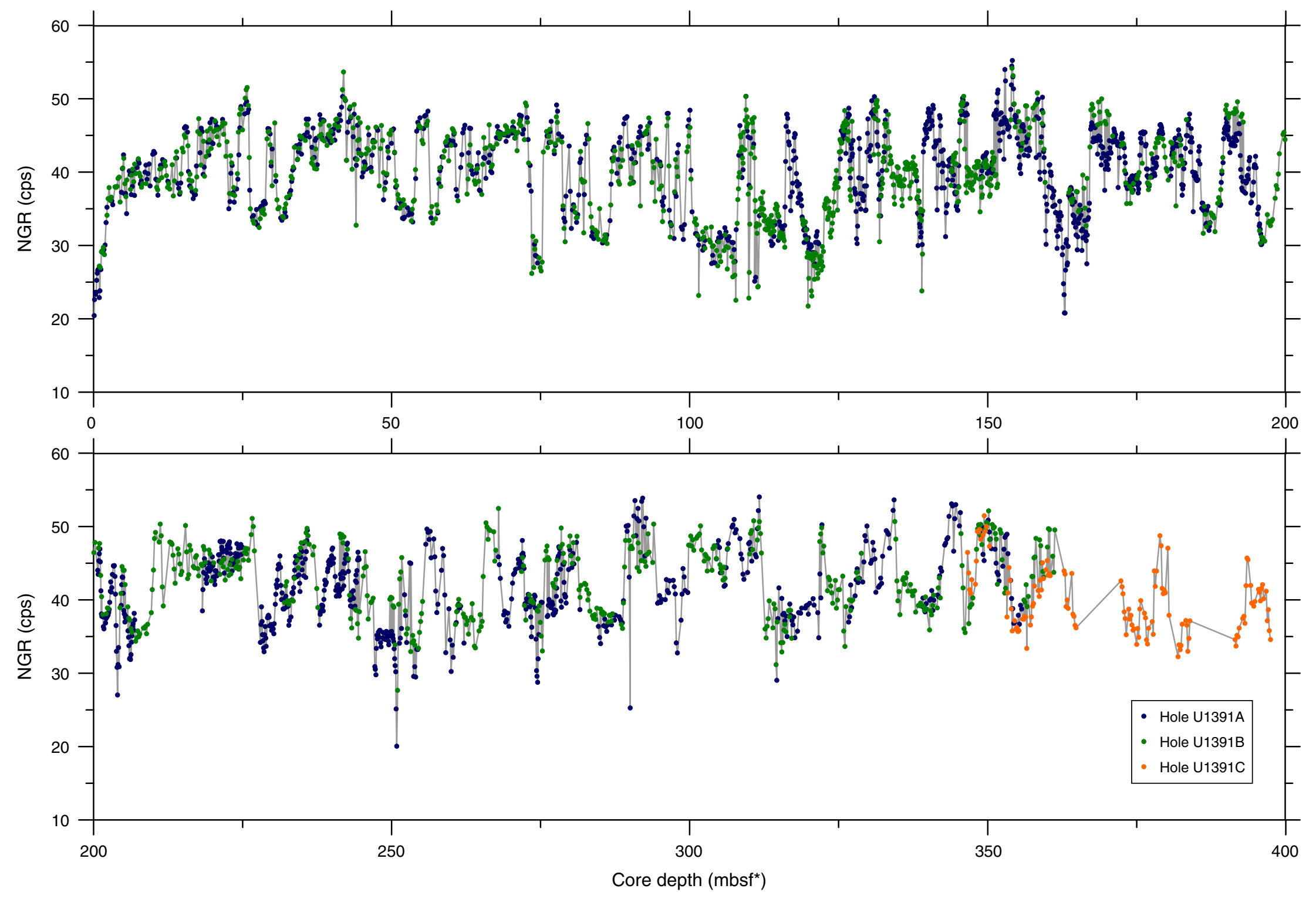
Table T1. Coring summary, Site U1391. (Continued on next two pages.)

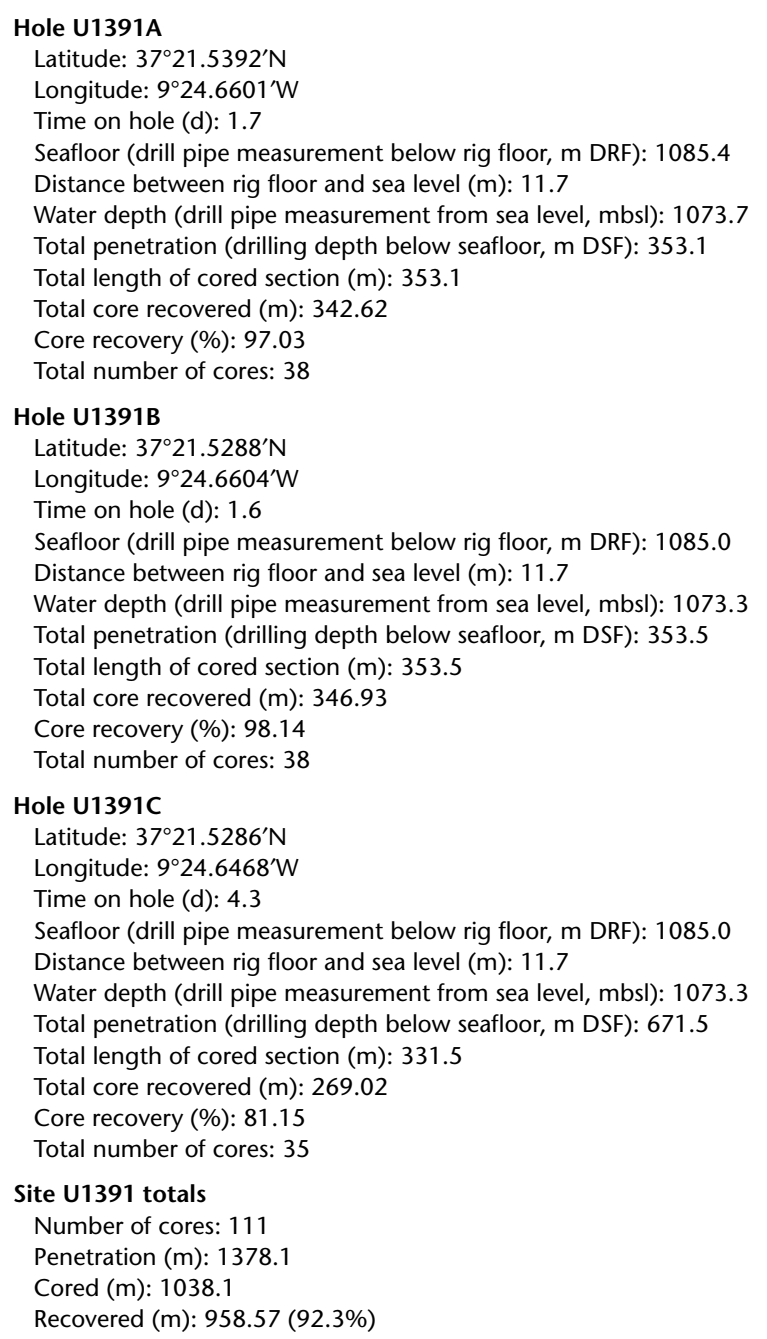

\begin{tabular}{|c|c|c|c|c|c|c|c|c|c|c|}
\hline \multirow[b]{2}{*}{ Core } & \multirow[b]{2}{*}{$\begin{array}{l}\text { Date } \\
(2012)\end{array}$} & \multirow[b]{2}{*}{$\begin{array}{c}\text { Time } \\
\text { (h) }\end{array}$} & \multicolumn{2}{|c|}{ Depth DSF $(m)$} & \multirow[b]{2}{*}{$\begin{array}{c}\text { Interval } \\
\text { advanced (m) }\end{array}$} & \multicolumn{2}{|c|}{ Depth CSF (m) } & \multirow[b]{2}{*}{$\begin{array}{l}\text { Length of core } \\
\text { recovered }(\mathrm{m})\end{array}$} & \multirow[b]{2}{*}{$\begin{array}{l}\text { Curated } \\
\text { length }(m)\end{array}$} & \multirow[b]{2}{*}{$\begin{array}{l}\text { Recovery } \\
\quad(\%)\end{array}$} \\
\hline & & & $\begin{array}{c}\text { Top of cored } \\
\text { interval }\end{array}$ & $\begin{array}{l}\text { Bottom of } \\
\text { cored interval }\end{array}$ & & $\begin{array}{l}\text { Top of } \\
\text { recovered core }\end{array}$ & $\begin{array}{l}\text { Bottom of } \\
\text { recovered core }\end{array}$ & & & \\
\hline \multicolumn{11}{|l|}{ 339-U1391A- } \\
\hline $1 \mathrm{H}$ & $8 \mathrm{Jan}$ & 2045 & 0.0 & 4.1 & 4.1 & 0.0 & 4.16 & 4.16 & 4.16 & 101 \\
\hline $2 \mathrm{H}$ & $8 \mathrm{Jan}$ & 2125 & 4.1 & 13.6 & 9.5 & 4.1 & 13.85 & 9.75 & 9.75 & 103 \\
\hline $3 \mathrm{H}$ & $8 \mathrm{Jan}$ & 2150 & 13.6 & 23.1 & 9.5 & 13.6 & 23.32 & 9.72 & 9.72 & 102 \\
\hline $4 \mathrm{H}$ & $8 \mathrm{Jan}$ & 2230 & 23.1 & 32.6 & 9.5 & 23.1 & 32.97 & 9.87 & 9.87 & 104 \\
\hline $5 \mathrm{H}$ & $8 \mathrm{Jan}$ & 2300 & 32.6 & 42.1 & 9.5 & 32.6 & 42.37 & 9.77 & 9.77 & 103 \\
\hline $6 \mathrm{H}$ & $8 \mathrm{Jan}$ & 2330 & 42.1 & 51.6 & 9.5 & 42.1 & 52.18 & 10.02 & 10.08 & 105 \\
\hline $7 \mathrm{H}$ & $9 \mathrm{Jan}$ & 0025 & 51.6 & 61.1 & 9.5 & 51.6 & 61.71 & 9.98 & 10.11 & 105 \\
\hline $8 \mathrm{H}$ & $9 \mathrm{Jan}$ & 0055 & 61.1 & 70.6 & 9.5 & 61.1 & 71.18 & 10.04 & 10.08 & 106 \\
\hline $9 \mathrm{H}$ & $9 \mathrm{Jan}$ & 0135 & 70.6 & 80.1 & 9.5 & 70.6 & 80.77 & 10.17 & 10.17 & 107 \\
\hline $10 \mathrm{H}$ & 9 Jan & 0215 & 80.1 & 89.6 & 9.5 & 80.1 & 90.17 & 10.07 & 10.07 & 106 \\
\hline $11 \mathrm{H}$ & $9 \mathrm{Jan}$ & 0250 & 89.6 & 99.1 & 9.5 & 89.6 & 99.52 & 9.92 & 9.92 & 104 \\
\hline $12 \mathrm{H}$ & $9 \operatorname{Jan}$ & 0330 & 99.1 & 108.6 & 9.5 & 99.1 & 109.17 & 10.07 & 10.07 & 106 \\
\hline $13 \mathrm{H}$ & 9 Jan & 0415 & 108.6 & 118.1 & 9.5 & 108.6 & 119.00 & 10.40 & 10.40 & 109 \\
\hline $14 \mathrm{H}$ & $9 \mathrm{Jan}$ & 0450 & 118.1 & 127.6 & 9.5 & 118.1 & 128.20 & 10.05 & 10.10 & 106 \\
\hline $15 \mathrm{H}$ & 9 Jan & 0525 & 127.6 & 137.1 & 9.5 & 127.6 & 136.99 & 9.47 & 9.39 & 100 \\
\hline $16 \mathrm{H}$ & $9 \mathrm{Jan}$ & 0610 & 137.1 & 146.6 & 9.5 & 137.1 & 148.03 & 10.93 & 10.93 & 115 \\
\hline $17 \mathrm{H}$ & 9 Jan & 0700 & 146.6 & 156.1 & 9.5 & 146.6 & 156.60 & 10.00 & 10.00 & 105 \\
\hline $18 \mathrm{H}$ & 9 Jan & 0740 & 156.1 & 165.6 & 9.5 & 156.1 & 167.22 & 11.12 & 11.12 & 117 \\
\hline $19 \mathrm{H}$ & 9 Jan & 0825 & 165.6 & 171.1 & 5.5 & 165.6 & 171.10 & 5.50 & 5.50 & 100 \\
\hline $20 x$ & $9 \mathrm{Jan}$ & 1140 & 171.1 & 180.7 & 9.6 & 171.1 & 179.87 & 8.77 & 8.77 & 91 \\
\hline $21 x$ & 9 Jan & 1210 & 180.7 & 190.2 & 9.5 & 180.7 & 189.27 & 8.57 & 8.57 & 90 \\
\hline $22 x$ & 9 Jan & 1245 & 190.2 & 199.8 & 9.6 & 190.2 & 199.40 & 9.20 & 9.20 & 96 \\
\hline $23 x$ & $9 \mathrm{Jan}$ & 1320 & 199.8 & 209.4 & 9.6 & 199.8 & 208.47 & 8.67 & 8.67 & 90 \\
\hline
\end{tabular}


Table T1 (continued). (Continued on next page.)

\begin{tabular}{|c|c|c|c|c|c|c|c|c|c|c|}
\hline \multirow[b]{2}{*}{ Core } & \multirow[b]{2}{*}{$\begin{array}{l}\text { Date } \\
(2012)\end{array}$} & \multirow[b]{2}{*}{$\begin{array}{l}\text { Time } \\
\text { (h) }\end{array}$} & \multicolumn{2}{|c|}{ Depth DSF $(m)$} & \multirow[b]{2}{*}{$\begin{array}{c}\text { Interval } \\
\text { advanced }(\mathrm{m})\end{array}$} & \multicolumn{2}{|c|}{ Depth CSF (m) } & \multirow[b]{2}{*}{$\begin{array}{l}\text { Length of core } \\
\text { recovered }(m)\end{array}$} & \multirow[b]{2}{*}{$\begin{array}{c}\text { Curated } \\
\text { length }(m)\end{array}$} & \multirow[b]{2}{*}{$\begin{array}{l}\text { Recovery } \\
(\%)\end{array}$} \\
\hline & & & $\begin{array}{l}\text { Top of cored } \\
\text { interval }\end{array}$ & $\begin{array}{c}\text { Bottom of } \\
\text { cored interval }\end{array}$ & & $\begin{array}{l}\text { Top of } \\
\text { recovered core }\end{array}$ & $\begin{array}{l}\text { Bottom of } \\
\text { recovered core }\end{array}$ & & & \\
\hline $24 X$ & 9 Jan & 1405 & 209.4 & 219.0 & 9.6 & 209.4 & 209.40 & 0.00 & 0.00 & 0 \\
\hline $25 x$ & 9 Jan & 1455 & 219.0 & 228.6 & 9.6 & 219.0 & 227.46 & 8.46 & 8.46 & 88 \\
\hline $26 \mathrm{X}$ & 9 Jan & 1555 & 228.6 & 238.2 & 9.6 & 228.6 & 238.67 & 10.07 & 10.07 & 105 \\
\hline $27 X$ & 9 Jan & 1645 & 238.2 & 247.8 & 9.6 & 238.2 & 246.58 & 8.38 & 8.38 & 87 \\
\hline $28 \mathrm{X}$ & $9 \operatorname{Jan}$ & 1735 & 247.8 & 257.4 & 9.6 & 247.8 & 256.97 & 9.17 & 9.17 & 96 \\
\hline $29 X$ & 9 Jan & 1835 & 257.4 & 267.0 & 9.6 & 257.4 & 265.74 & 8.34 & 8.34 & 87 \\
\hline $30 x$ & 9 Jan & 1955 & 267.0 & 276.6 & 9.6 & 267.0 & 276.52 & 9.52 & 9.52 & 99 \\
\hline $31 x$ & 9 Jan & 2045 & 276.6 & 286.2 & 9.6 & 276.6 & 283.75 & 7.15 & 7.15 & 74 \\
\hline $32 x$ & 9 Jan & 2135 & 286.2 & 295.8 & 9.6 & 286.2 & 296.25 & 10.05 & 10.05 & 105 \\
\hline $33 x$ & $9 \operatorname{Jan}$ & 2235 & 295.8 & 305.1 & 9.3 & 295.8 & 302.70 & 6.90 & 6.90 & 74 \\
\hline $34 \mathrm{X}$ & 9 Jan & 2330 & 305.1 & 314.7 & 9.6 & 305.1 & 314.56 & 9.46 & 9.46 & 99 \\
\hline $35 x$ & $10 \operatorname{Jan}$ & 0025 & 314.7 & 324.3 & 9.6 & 314.7 & 324.44 & 9.74 & 9.74 & 101 \\
\hline $36 \mathrm{X}$ & $10 \mathrm{Jan}$ & 0115 & 324.3 & 333.9 & 9.6 & 324.3 & 334.10 & 9.80 & 9.80 & 102 \\
\hline $37 X$ & 10 Jan & 0210 & 333.9 & 343.5 & 9.6 & 333.9 & 343.25 & 9.35 & 9.35 & 97 \\
\hline $38 \mathrm{X}$ & 10 Jan & 0315 & 343.5 & 353.1 & 9.6 & 343.5 & 353.51 & 10.01 & 10.01 & 104 \\
\hline & & & $\mathrm{Ad}$ & vanced total: & 353.1 & & & & & \\
\hline & & & Total ir & terval cored: & 353.1 & & & & & \\
\hline 339-U1391 & & & & & & & & & & \\
\hline $1 \mathrm{H}$ & $10 \operatorname{Jan}$ & 0825 & 0.0 & 9.5 & 9.5 & 0.0 & 9.66 & 9.65 & 9.66 & 102 \\
\hline $2 \mathrm{H}$ & 10 Jan & 0930 & 9.5 & 19.0 & 9.5 & 9.5 & 19.54 & 10.04 & 10.04 & 106 \\
\hline $3 \mathrm{H}$ & 10 Jan & 1000 & 19.0 & 28.5 & 9.5 & 19.0 & 28.89 & 9.89 & 9.89 & 104 \\
\hline $4 \mathrm{H}$ & 10 Jan & 1040 & 28.5 & 38.0 & 9.5 & 28.5 & 38.58 & 10.08 & 10.08 & 106 \\
\hline $5 \mathrm{H}$ & $10 \operatorname{Jan}$ & 1125 & 38.0 & 47.5 & 9.5 & 38.0 & 47.89 & 9.89 & 9.89 & 104 \\
\hline $6 \mathrm{H}$ & $10 \mathrm{Jan}$ & 1205 & 47.5 & 57.0 & 9.5 & 47.5 & 57.71 & 10.05 & 10.21 & 106 \\
\hline $7 \mathrm{H}$ & $10 \mathrm{Jan}$ & 1235 & 57.0 & 66.5 & 9.5 & 57.0 & 67.07 & 10.07 & 10.07 & 106 \\
\hline $8 \mathrm{H}$ & $10 \mathrm{Jan}$ & 1335 & 66.5 & 76.0 & 9.5 & 66.5 & 76.94 & 10.44 & 10.44 & 110 \\
\hline $9 \mathrm{H}$ & 10 Jan & 1405 & 76.0 & 85.5 & 9.5 & 76.0 & 86.25 & 10.24 & 10.25 & 108 \\
\hline $10 \mathrm{H}$ & $10 \mathrm{Jan}$ & 1435 & 85.5 & 95.0 & 9.5 & 85.5 & 95.69 & 10.16 & 10.19 & 107 \\
\hline $11 \mathrm{H}$ & 10 Jan & 1520 & 95.0 & 104.5 & 9.5 & 95.0 & 104.98 & 9.98 & 9.98 & 105 \\
\hline $12 \mathrm{H}$ & $10 \mathrm{Jan}$ & 1600 & 104.5 & 114.0 & 9.5 & 104.5 & 114.83 & 10.44 & 10.33 & 110 \\
\hline $13 \mathrm{H}$ & 10 Jan & 1635 & 114.0 & 123.5 & 9.5 & 114.0 & 123.75 & 9.75 & 9.75 & 103 \\
\hline $14 \mathrm{H}$ & $10 \mathrm{Jan}$ & 1730 & 123.5 & 133.0 & 9.5 & 123.5 & 133.77 & 10.25 & 10.27 & 108 \\
\hline $15 \mathrm{H}$ & $10 \mathrm{Jan}$ & 1820 & 133.0 & 142.5 & 9.5 & 133.0 & 143.45 & 10.43 & 10.45 & 110 \\
\hline $16 \mathrm{H}$ & $10 \mathrm{Jan}$ & 1855 & 142.5 & 152.0 & 9.5 & 142.5 & 152.17 & 9.65 & 9.67 & 102 \\
\hline $17 \mathrm{H}$ & $10 \mathrm{Jan}$ & 1935 & 152.0 & 161.5 & 9.5 & 152.0 & 159.42 & 7.40 & 7.42 & 78 \\
\hline $18 \mathrm{H}$ & 10 Jan & 2025 & 161.5 & 171.0 & 9.5 & 161.5 & 170.94 & 9.43 & 9.44 & 99 \\
\hline $19 \mathrm{X}$ & $10 \mathrm{Jan}$ & 2130 & 171.0 & 175.5 & 4.5 & 171.0 & 175.71 & 4.70 & 4.71 & 104 \\
\hline $20 x$ & $10 \mathrm{Jan}$ & 2210 & 175.5 & 185.1 & 9.6 & 175.5 & 184.51 & 9.01 & 9.01 & 94 \\
\hline $21 x$ & $10 \operatorname{Jan}$ & 2305 & 185.1 & 194.6 & 9.5 & 185.1 & 193.83 & 8.73 & 8.73 & 92 \\
\hline $22 x$ & $10 \operatorname{Jan}$ & 2340 & 194.6 & 204.2 & 9.6 & 194.6 & 203.12 & 8.52 & 8.52 & 89 \\
\hline $23 x$ & $11 \mathrm{Jan}$ & 0025 & 204.2 & 213.8 & 9.6 & 204.2 & 213.53 & 9.23 & 9.33 & 96 \\
\hline $24 X$ & 11 Jan & 0120 & 213.8 & 223.4 & 9.6 & 213.8 & 223.28 & 9.48 & 9.48 & 99 \\
\hline $25 x$ & 11 Jan & 0155 & 223.4 & 233.0 & 9.6 & 223.4 & 231.21 & 7.81 & 7.81 & 81 \\
\hline $26 \mathrm{X}$ & $11 \mathrm{Jan}$ & 0235 & 233.0 & 242.6 & 9.6 & 233.0 & 240.53 & 7.53 & 7.53 & 78 \\
\hline $27 X$ & $11 \mathrm{Jan}$ & 0320 & 242.6 & 252.2 & 9.6 & 242.6 & 250.13 & 7.53 & 7.53 & 78 \\
\hline $28 \mathrm{X}$ & $11 \mathrm{Jan}$ & 0400 & 252.2 & 261.8 & 9.6 & 252.2 & 259.70 & 7.50 & 7.50 & 78 \\
\hline $29 X$ & 11 Jan & 0440 & 261.8 & 271.4 & 9.6 & 261.8 & 271.05 & 9.25 & 9.25 & 96 \\
\hline $30 x$ & $11 \mathrm{Jan}$ & 0520 & 271.4 & 281.0 & 9.6 & 271.4 & 280.99 & 9.59 & 9.59 & 100 \\
\hline $31 x$ & $11 \mathrm{Jan}$ & 0600 & 281.0 & 290.6 & 9.6 & 281.0 & 289.87 & 8.87 & 8.87 & 92 \\
\hline $32 x$ & $11 \mathrm{Jan}$ & 0640 & 290.6 & 300.2 & 9.6 & 290.6 & 298.63 & 8.03 & 8.03 & 84 \\
\hline $33 x$ & $11 \mathrm{Jan}$ & 0725 & 300.2 & 309.8 & 9.6 & 300.2 & 308.79 & 8.59 & 8.59 & 89 \\
\hline $34 X$ & 11 Jan & 0805 & 309.8 & 319.0 & 9.2 & 309.8 & 318.90 & 9.10 & 9.10 & 99 \\
\hline $35 x$ & 11 Jan & 0855 & 319.0 & 328.7 & 9.7 & 319.0 & 328.74 & 9.74 & 9.74 & 100 \\
\hline $36 x$ & $11 \mathrm{Jan}$ & 0950 & 328.7 & 338.2 & 9.5 & 328.7 & 338.45 & 9.75 & 9.75 & 103 \\
\hline $37 X$ & 11 Jan & 1035 & 338.2 & 347.9 & 9.7 & 338.2 & 347.71 & 9.51 & 9.51 & 98 \\
\hline $38 \mathrm{X}$ & 11 Jan & 1125 & 347.9 & 353.5 & 5.6 & 347.9 & 354.52 & 6.62 & 6.62 & 118 \\
\hline & & & & vanced total: & 353.5 & & & & & \\
\hline & & & Total ir & terval cored: & 353.5 & & & & & \\
\hline 339-U1391 & & & & & & & & & & \\
\hline $1 \mathrm{~W}$ & 12 Jan & 1425 & & & $* * * *$ Drilled & from 0 to 340. & $\mathrm{~m} \mathrm{DSF}$ without & t coring & & \\
\hline $2 \mathrm{R}$ & $12 \operatorname{Jan}$ & 1525 & 340.0 & 345.5 & 5.5 & 340.0 & 345.05 & 5.05 & 5.05 & 92 \\
\hline $3 \mathrm{R}$ & 12 Jan & 1640 & 345.5 & 355.1 & 9.6 & 345.5 & 354.53 & 9.03 & 9.03 & 94 \\
\hline $4 \mathrm{R}$ & 12 Jan & 1810 & 355.1 & 364.7 & 9.6 & 355.1 & 357.98 & 2.88 & 2.88 & 30 \\
\hline $5 \mathrm{R}$ & $12 \operatorname{Jan}$ & 1935 & 364.7 & 374.3 & 9.6 & 364.7 & 374.53 & 9.83 & 9.83 & 102 \\
\hline $6 \mathrm{R}$ & 12 Jan & 2105 & 374.3 & 383.9 & 9.6 & 374.3 & 377.37 & 3.07 & 3.07 & 32 \\
\hline $7 \mathrm{R}$ & $12 \operatorname{Jan}$ & 2220 & 383.9 & 393.5 & 9.6 & 383.9 & 391.49 & 7.59 & 7.59 & 79 \\
\hline $8 \mathrm{R}$ & $12 \operatorname{Jan}$ & 2335 & 393.5 & 403.0 & 9.5 & 393.5 & 399.94 & 6.44 & 6.44 & 68 \\
\hline
\end{tabular}


Table T1 (continued).

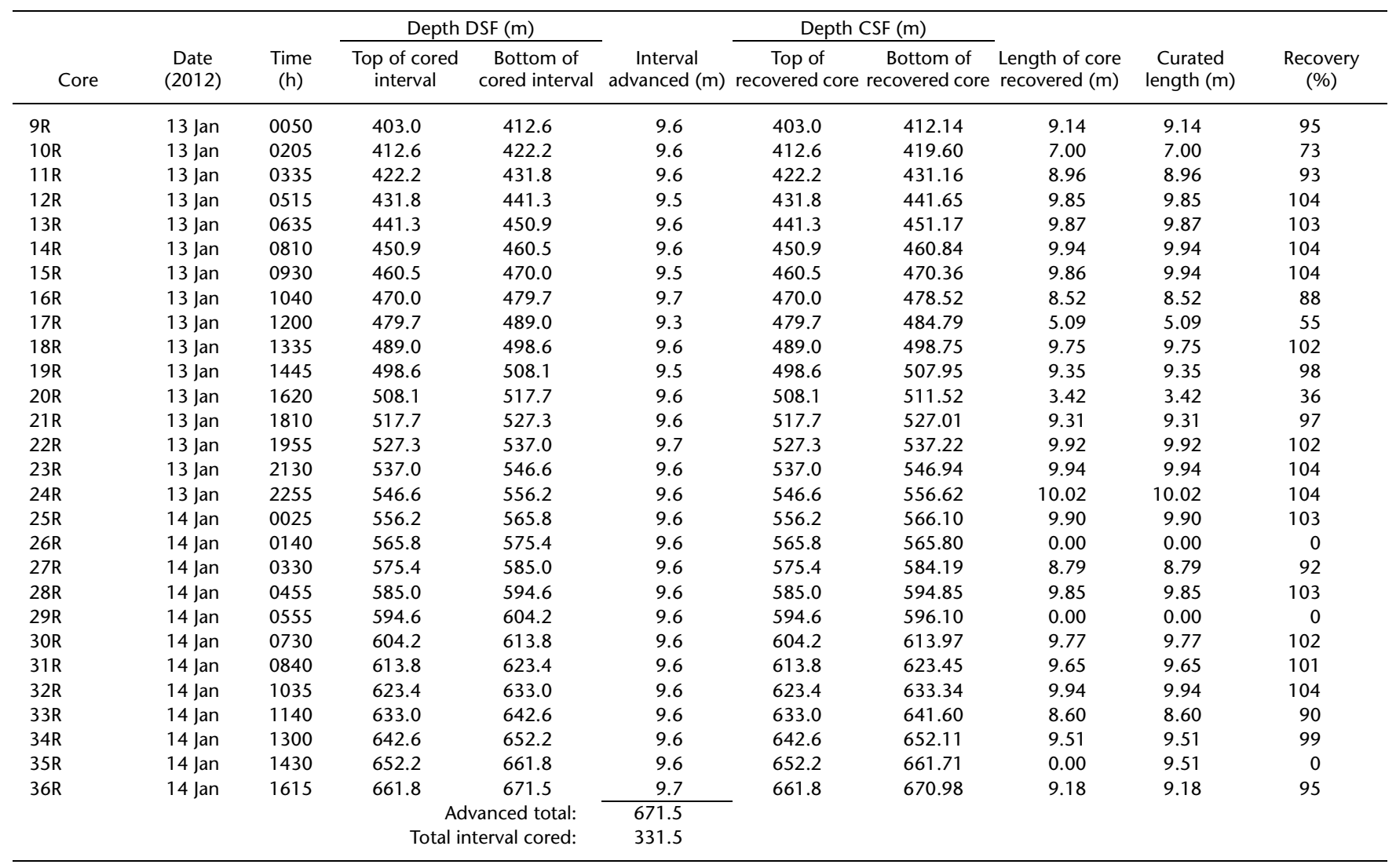

$\mathrm{DRF}=$ drilling depth below rig floor, $\mathrm{DSF}=$ drilling depth below seafloor, $\mathrm{CSF}=$ core depth below seafloor. $\mathrm{H}=$ advanced piston coring system, $\mathrm{X}$ = extended core barrel system, $\mathrm{R}=$ rotary core barrel system, $\mathrm{W}=$ washed interval. Time is Universal Time Coordinated.

Table T2. Sediment textures and compositions determined by smear slide, Site U1391.

\begin{tabular}{cccccccccc}
\hline & \multicolumn{3}{c}{ Texture (\%) } & & \multicolumn{4}{c}{ Composition (\%) } \\
\cline { 2 - 3 } \cline { 8 - 9 } Lith. unit & Sand & Silt & Clay & & Siliciclastic & $\begin{array}{c}\text { Detrital } \\
\text { carbonate }\end{array}$ & $\begin{array}{c}\text { Biogenic } \\
\text { carbonate }\end{array}$ & $\begin{array}{c}\text { Biogenic } \\
\text { silica }\end{array}$ \\
\hline IA & 15 & 31 & 54 & & 43 & 26 & 30 & 1 \\
IB & 8 & 27 & 65 & & 32 & 30 & 35 & 3 \\
II & 9 & 31 & 60 & & 40 & 23 & 28 & 7 \\
\hline
\end{tabular}


Table T3. XRD peak intensities of minerals from bulk sediment, Hole U1391A.

\begin{tabular}{|c|c|c|c|c|c|c|c|c|c|c|c|c|c|c|c|}
\hline $\begin{array}{l}\text { Core, section, } \\
\text { interval }(\mathrm{cm})\end{array}$ & $\begin{array}{l}\text { Depth } \\
\text { (mbsf) }\end{array}$ & $\begin{array}{c}\text { Total } \\
\text { intensity } \\
\text { (counts) }\end{array}$ & $\begin{array}{c}\text { Quartz } \\
\text { (counts) }\end{array}$ & $\begin{array}{l}\text { Calcite } \\
\text { (counts) }\end{array}$ & $\begin{array}{c}\text { K-feldspar } \\
\text { (counts) }\end{array}$ & $\begin{array}{l}\text { Plagioclase } \\
\text { (counts) }\end{array}$ & $\begin{array}{l}\text { Dolomite } \\
\text { (counts) }\end{array}$ & $\begin{array}{l}\text { Chlorite } \\
\text { (counts) }\end{array}$ & $\begin{array}{l}\text { Kaolinite } \\
\text { (counts) }\end{array}$ & $\begin{array}{c}\text { Illite } \\
\text { (counts) }\end{array}$ & $\begin{array}{l}\text { Smectite } \\
\text { (counts) }\end{array}$ & $\begin{array}{l}\text { Hornblende } \\
\text { (counts) }\end{array}$ & $\begin{array}{c}\text { Augite } \\
\text { (counts) }\end{array}$ & $\begin{array}{c}\text { Pyrite } \\
\text { (counts) }\end{array}$ & $\begin{array}{c}\text { Aragonite } \\
\text { (counts) }\end{array}$ \\
\hline \multicolumn{16}{|l|}{ 339-U1391A- } \\
\hline $1 \mathrm{H}-3,75-76$ & 3.75 & 44,840 & 22,382 & 12,464 & 447 & 995 & 1,616 & 746 & 1,593 & 3,664 & 293 & NA & 640 & NA & NA \\
\hline $2 \mathrm{H}-6,110-111$ & 12.7 & 55,931 & 30,606 & 12,475 & 1,037 & 1,409 & 1,701 & 888 & 1,515 & 4,417 & 241 & 941 & 701 & NA & NA \\
\hline $3 \mathrm{H}-6,115-116$ & 22.25 & 66,039 & 22,324 & 11,165 & 1,914 & 2,588 & 2,217 & 2,485 & 4,201 & 17,618 & 670 & 193 & 664 & NA & NA \\
\hline $4 \mathrm{H}-6,137-138$ & 31.97 & 55,399 & 32,548 & 11,012 & 706 & 1,414 & 1,547 & 842 & 1,446 & 4,678 & 249 & 391 & 566 & NA & NA \\
\hline $5 \mathrm{H}-6,139-140$ & 41.49 & 52,314 & 25,694 & 13,832 & 527 & 987 & 2,206 & 779 & 1,771 & 5,340 & 392 & 135 & 651 & NA & NA \\
\hline $6 \mathrm{H}-6,127-128$ & 50.92 & 65,628 & 40,331 & 12,018 & 718 & 2,014 & 1,996 & 742 & 1,270 & 5,136 & 347 & 487 & 569 & NA & NA \\
\hline $7 \mathrm{H}-6,137-138$ & 60.67 & 49,638 & 25,155 & 15,195 & 708 & 1,691 & 1,332 & NA & 935 & 3,063 & 281 & 161 & 525 & NA & 592 \\
\hline $8 \mathrm{H}-6,125-126$ & 69.73 & 57,184 & 27,935 & 16,153 & 515 & 1,633 & 1,945 & 944 & 1,550 & 4,898 & 299 & 154 & 644 & NA & 514 \\
\hline $9 \mathrm{H}-6,128-129$ & 79.23 & 55,116 & 19,998 & 24,970 & 297 & 988 & 2,033 & 574 & 1,229 & 4,106 & 272 & 265 & NA & NA & 384 \\
\hline $10 \mathrm{H}-6,122-123$ & 88.46 & 56,278 & 25,784 & 14,340 & 657 & 4,543 & 2,923 & 862 & 1,481 & 4,721 & 271 & 209 & 487 & NA & NA \\
\hline $11 \mathrm{H}-7,127-128$ & 99.16 & 48,006 & 24,448 & 12,242 & 748 & 1,507 & 1,478 & 820 & 1,371 & 4,178 & 351 & 226 & 637 & NA & NA \\
\hline $12 \mathrm{H}-6,137-138$ & 106.44 & 50,164 & 16,948 & 22,975 & NA & 797 & 1,050 & 823 & 1,361 & 5,165 & 333 & 65 & 454 & 193 & NA \\
\hline $13 \mathrm{H}-6,135-136$ & 116.55 & 49,274 & 28,527 & 10,409 & 524 & 1,267 & 925 & 820 & 1,334 & 4,288 & 265 & 226 & 689 & NA & NA \\
\hline $14 \mathrm{H}-6,135-136$ & 126.55 & 62,638 & 22,196 & 25,996 & 468 & 1,242 & 2,407 & 999 & 1,778 & 6,231 & 494 & 167 & NA & NA & 660 \\
\hline $15 \mathrm{H}-6,119-120$ & 135.92 & 47,738 & 22,192 & 16,469 & 324 & 1,379 & 1,471 & 647 & 1,066 & 3,025 & 264 & 232 & 522 & 147 & NA \\
\hline $16 \mathrm{H}-6,135-136$ & 144.58 & 66,256 & 36,842 & 14,373 & 728 & 2,249 & 2,934 & 909 & 1,685 & 4,935 & 280 & 519 & NA & NA & 802 \\
\hline $17 \mathrm{H}-6,124-125$ & 154.98 & 58,136 & 29,977 & 15,118 & 635 & 1,415 & 4,313 & 535 & 1,160 & 3,850 & 340 & 130 & NA & NA & 663 \\
\hline $18 \mathrm{H}-6,70-71$ & 163.28 & 51,358 & 23,823 & 17,636 & 374 & 1,033 & 2,086 & 762 & 1,135 & 3,326 & 429 & 143 & NA & NA & 611 \\
\hline $19 \mathrm{H}-3,124-125$ & 169.52 & 48,796 & 23,729 & 13,096 & 495 & 2,169 & 1,991 & 785 & 1,226 & 3,928 & 579 & 217 & 581 & NA & NA \\
\hline $20 X-5,135-136$ & 178.45 & 46,141 & 23,068 & 11,409 & 495 & 1,178 & 1,872 & 868 & 1,650 & 4,432 & 350 & 156 & 663 & NA & NA \\
\hline $21 X-5,114-115$ & 187.77 & 50,059 & 21,912 & 19,845 & 466 & 980 & 1,548 & 551 & 1,075 & 3,083 & 378 & 221 & NA & NA & NA \\
\hline 22X-7, 118-119 & 198.56 & 62,242 & 27,576 & 17,847 & 782 & 1,803 & 2,216 & 1,231 & 2,056 & 7,545 & 395 & 186 & NA & NA & 605 \\
\hline $23 X-6,74-75$ & 207.76 & 66,610 & 29,591 & 13,666 & 2,227 & 1,509 & 7,466 & 1,161 & 1,878 & 7,337 & 354 & 207 & 589 & NA & 625 \\
\hline $25 X-6,49-50$ & 226.74 & 56,401 & 22,346 & 12,945 & 818 & 1,770 & 2,054 & 1,685 & 2,868 & 10,369 & 725 & 136 & 505 & 180 & NA \\
\hline $26 \mathrm{X}-6,127-128$ & 236.17 & 66,895 & 28,560 & 12,387 & 1,102 & 2,172 & 3,559 & 2,084 & 2,981 & 12,419 & 692 & 339 & 600 & NA & NA \\
\hline $27 \mathrm{X}-6,96-97$ & 245.94 & 67,684 & 31,837 & 9,104 & 929 & 2,804 & 1,698 & 2,159 & 3,119 & 14,326 & 513 & 354 & 634 & 207 & NA \\
\hline $28 X-6,65-66$ & 254.95 & 59,200 & 31,118 & 10,879 & 1,364 & 1,773 & 1,760 & 1,602 & 2,193 & 7,274 & 543 & 145 & 549 & NA & NA \\
\hline $29 \times-6,43-44$ & 265.15 & 54,085 & 24,049 & 15,433 & NA & 6,443 & 2,563 & 669 & 1,173 & 3,240 & 398 & 117 & NA & NA & NA \\
\hline $30 X-6,130-131$ & 275.13 & 53,033 & 25,551 & 16,329 & 457 & 1,141 & 2,361 & 1,016 & 1,542 & 4,010 & 514 & 112 & NA & NA & NA \\
\hline $31 X-6,57-58$ & 283.21 & 47,476 & 23,159 & 13,522 & 655 & 1,077 & 3,209 & 593 & 1,148 & 3,492 & 459 & NA & NA & 162 & NA \\
\hline $32 X-6,141-142$ & 294.41 & 67,611 & 23,855 & 9,923 & 1,052 & 2,424 & 2,201 & 3,002 & 4,479 & 18,936 & 600 & 410 & 729 & NA & NA \\
\hline $33 X-4,123-124$ & 301.53 & 59,491 & 24,871 & 12,494 & 943 & 3,361 & 2,407 & 1,625 & 2,285 & 10,092 & 605 & 156 & 652 & NA & NA \\
\hline $34 \mathrm{X}-6,128-129$ & 313.85 & 54,185 & 31,414 & 9,005 & 926 & 2,730 & 2,021 & 886 & 1,474 & 4,438 & 338 & 242 & 711 & NA & NA \\
\hline $35 X-6,39-40$ & 322.05 & 53,014 & 25,251 & 17,303 & 493 & 1,499 & 1,248 & 874 & 1,425 & 3,988 & 329 & 154 & 450 & NA & NA \\
\hline $36 \mathrm{X}-6,116-117$ & 332.71 & 51,778 & 30,304 & 8,901 & 719 & 1,944 & 1,874 & 838 & 1,235 & 4,245 & 340 & 385 & 580 & 413 & NA \\
\hline $37 X-6,130-135$ & 341.37 & 51,375 & 27,132 & 9,914 & 895 & 1,679 & 2,378 & 940 & 1,653 & 5,153 & 363 & 212 & 636 & 420 & NA \\
\hline $38 X-6,75-76$ & 351.66 & 56,854 & 30,126 & 15,391 & 655 & 1,234 & 2,144 & 798 & 1,718 & 4,179 & 345 & 264 & NA & NA & NA \\
\hline
\end{tabular}

$\mathrm{NA}=$ no peak detected. 
Table T4. Biostratigraphic datums, Site U1391.

\begin{tabular}{|c|c|c|c|c|c|c|c|c|c|c|c|}
\hline \multirow[b]{2}{*}{ Event } & \multirow[b]{2}{*}{ Reference } & \multirow{2}{*}{$\begin{array}{l}\text { Age } \\
(\mathrm{Ma})\end{array}$} & \multicolumn{3}{|c|}{ Hole U1391A depth (mbsf) } & \multicolumn{3}{|c|}{ Hole U1391B depth (mbsf) } & \multicolumn{3}{|c|}{ Hole U1391C depth (mbsf) } \\
\hline & & & Top & Bottom & Mean & Top & Bottom & Mean & Top & Bottom & Mean \\
\hline LrO Emiliania huxleyi $(>4 \mu \mathrm{m})$ & Flores et al., 2010 & 0.01 & 2.92 & 3.60 & 3.26 & 0.00 & 9.61 & 4.80 & & & \\
\hline FO Emiliania huxleyi & Raffi et al., 2006 & 0.26 & 70.18 & 71.35 & 70.76 & 67.07 & 76.94 & 72.00 & & & \\
\hline LO Pseudoemiliania lacunosa & Raffi et al., 2006 & 0.46 & 114.57 & 115.95 & 115.26 & 114.83 & 123.75 & 119.29 & & & \\
\hline Stilostomella extinction & Hayward, 2002; Kawagata et al., 2005 & 0.65 & 189.27 & 199.40 & 194.33 & & & & & & \\
\hline LO Reticulofenestra asanoi & Raffi et al., 2006 & 0.90 & 227.46 & 231.11 & 229.28 & 231.21 & 240.53 & 235.87 & & & \\
\hline FO Reticulofenestra asanoi & Raffi et al., 2006 & 1.07 & 291.84 & 294.70 & 293.27 & 298.63 & 308.79 & 303.71 & & & \\
\hline $\begin{array}{l}\text { T paracme Neogloboquadrina } \\
\text { pachyderma (sin) }\end{array}$ & Lourens et al., 2004 & 1.21 & 324.44 & 334.10 & 329.27 & 318.90 & 328.74 & 323.82 & & & \\
\hline LO large Gephyrocapsa (>5.5 um) & Raffi et al., 2006 & 1.24 & 334.10 & 343.25 & 338.68 & 328.74 & 338.45 & 333.60 & & & \\
\hline LO Helicosphaera sellii & Raffi et al., 2006 & 1.25 & 343.25 & 353.51 & 348.38 & 328.74 & 338.45 & 333.60 & & & \\
\hline FO large Gephyrocapsa (>5.5 um) & Raffi et al., 2006 & 1.61 & & & & & & & 391.49 & 399.92 & 395.71 \\
\hline LO Calcidiscus macintyrei & Raffi et al., 2006 & 1.66 & & & & & & & 399.92 & 412.14 & 406.03 \\
\hline LO Discoaster brouweri & Raffi et al., 2006 & 1.95 & & & & & & & 470.36 & 478.52 & 474.44 \\
\hline FO Globorotalia inflata & Lourens et al., 2004 & 2.09 & & & & & & & 498.75 & 507.95 & 503.35 \\
\hline T Neogloboquadrina atlantica (sin) & Weaver and Clement, 1987 & 2.41 & & & & & & & 546.94 & 556.62 & 551.78 \\
\hline LO Globorotalia puncticulata & Lourens et al., 2004 & 2.41 & & & & & & & 556.62 & 566.10 & 561.36 \\
\hline LO Discoaster surculus & Raffi et al., 2006 & 2.53 & & & & & & & 556.62 & 566.10 & 561.36 \\
\hline LO Discoaster tamalis & Raffi et al., 2006 & 2.80 & & & & & & & 594.85 & 613.97 & 604.41 \\
\hline $\begin{array}{l}\text { Coiling change Globorotalia } \\
\text { crassaformis }\end{array}$ & Zachariasse et al., 1991 & 2.99 & & & & & & & 594.85 & 613.97 & 604.41 \\
\hline LO Sphaeroidinellopsis seminula & Lourens et al., 2004 & 3.19 & & & & & & & 639.35 & 641.6 & 637.47 \\
\hline $\begin{array}{l}\text { T disappearance of Globorotalia } \\
\text { puncticulata }\end{array}$ & Lourens et al., 2005 & 3.31 & & & & & & & 652.11 & 670.98 & 661.545 \\
\hline
\end{tabular}

$\mathrm{LO}=$ last occurrence, $\mathrm{FO}=$ first occurrence, $\mathrm{LrO}=$ last regular occurrence, $\mathrm{T}=$ top. $\sin =$ sinistral. 
Table T5. Abundance of nannofossils, Site U1391. (Continued on next two pages.)

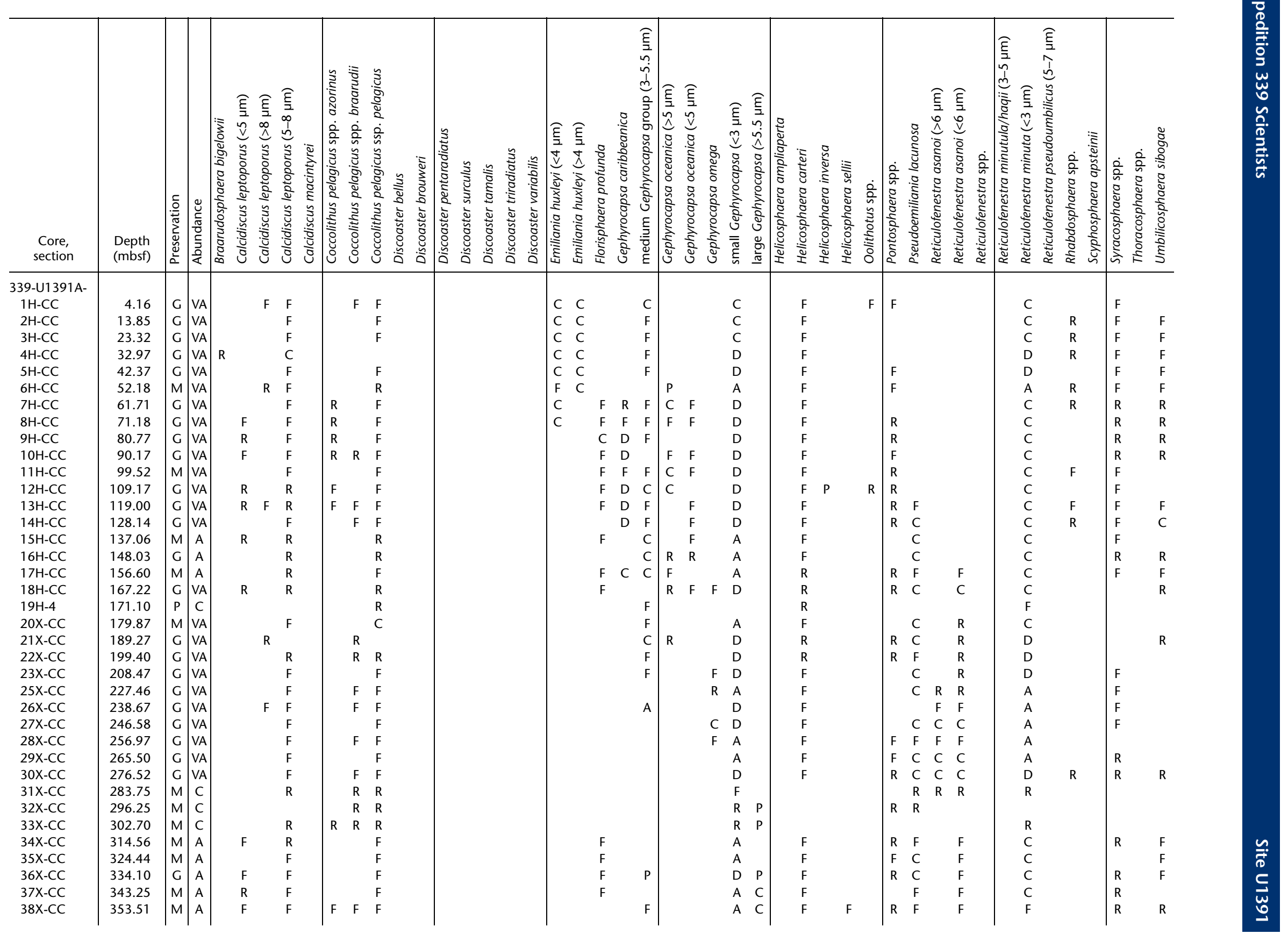


Table T5 (continued). (Continued on next page.)

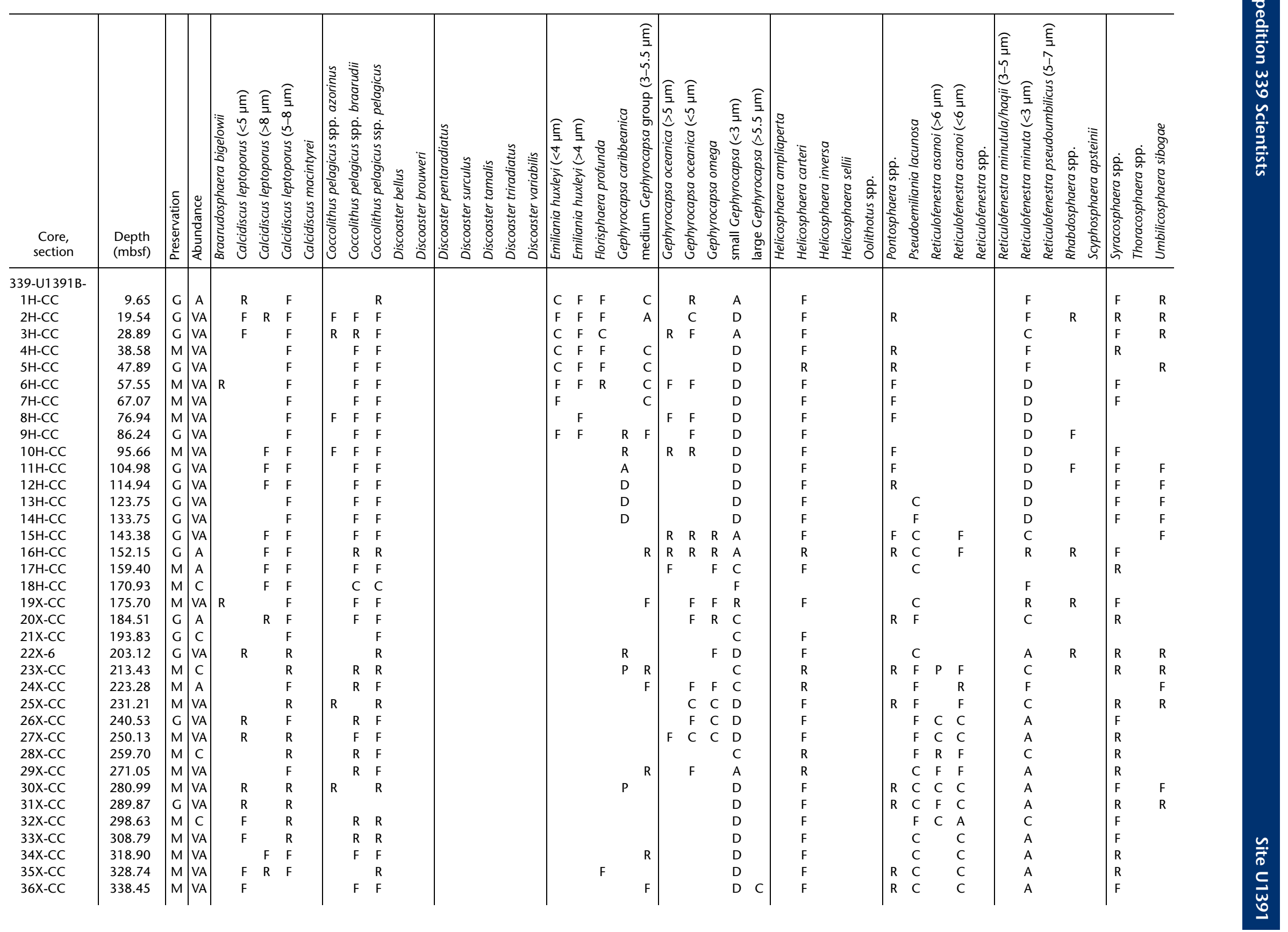


Table T5 (continued).

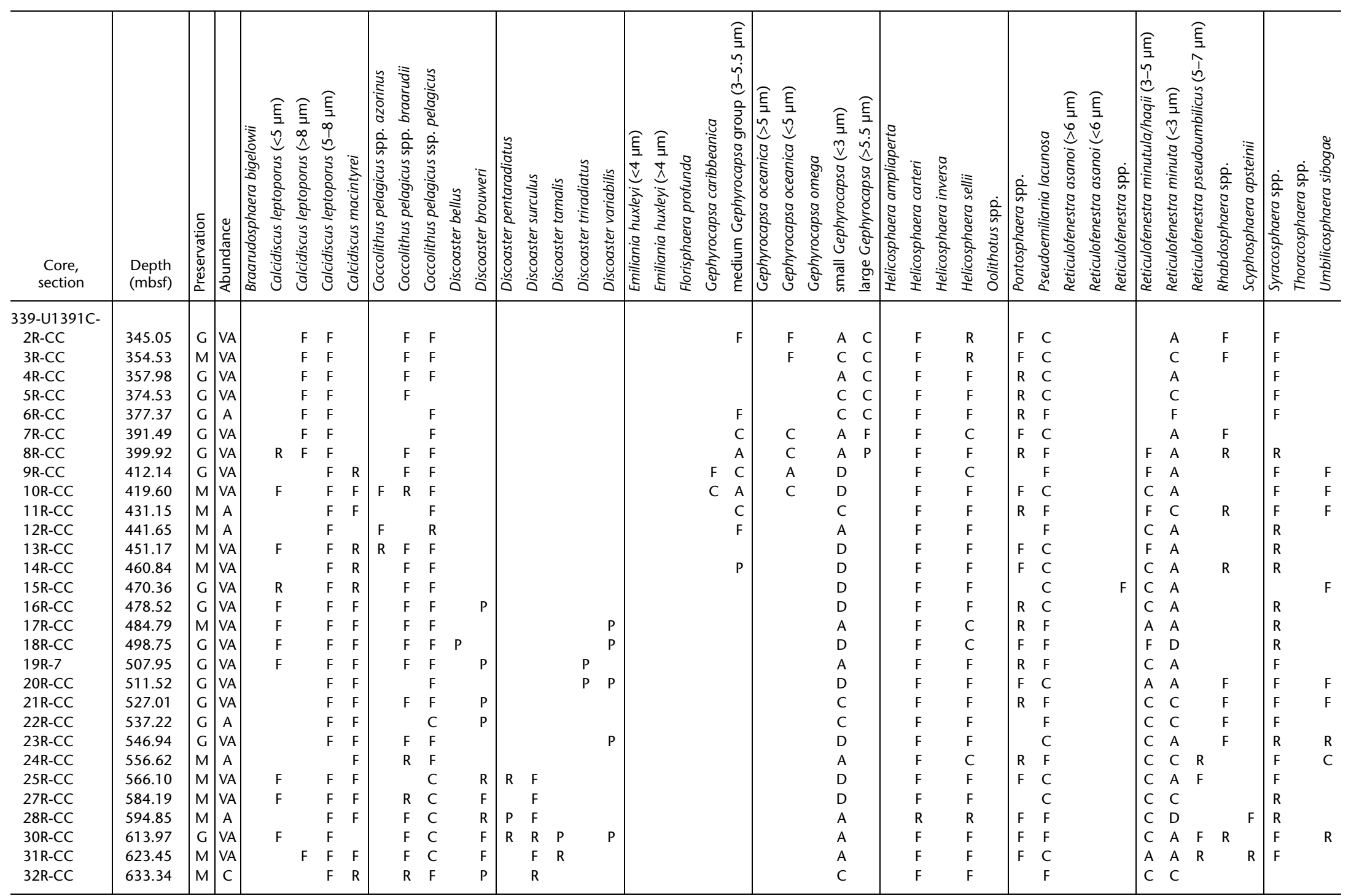

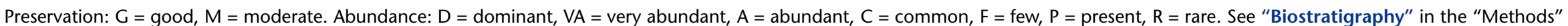
chapter (Expedition 339 Scientists, 2013b) for abundance and preservation definitions. 
Table T6. Abundance of planktonic foraminifers, Site U1391. This table is available in an oversized format.

Table T7. Abundance of benthic foraminifers, Site U1391. This table is available in an oversized format.

Table T8. Abundance of pollen and spores, Holes U1391A and U1391C.

\begin{tabular}{|c|c|c|c|c|c|c|c|c|c|c|c|c|c|c|c|c|c|c|c|c|c|c|c|c|c|c|c|}
\hline \multirow{2}{*}{$\begin{array}{l}\text { Core, } \\
\text { section }\end{array}$} & \multicolumn{2}{|c|}{ Depth (mbsf) } & \multirow{2}{*}{ 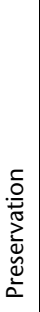 } & \multirow{2}{*}{ 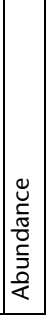 } & \multirow{2}{*}{ 号 } & \multirow{2}{*}{ 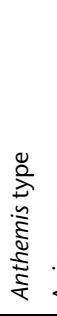 } & \multirow{2}{*}{$\begin{array}{l}\mathbb{\Xi} \\
\frac{\mathbb{U}}{\pi} \\
\frac{\pi}{2} \\
\frac{\pi}{4}\end{array}$} & \multirow{2}{*}{ 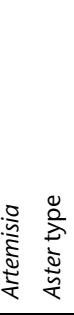 } & \multirow{2}{*}{ 这 } & \multirow{2}{*}{\multicolumn{2}{|c|}{ 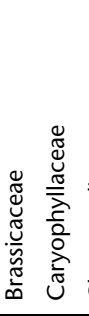 }} & \multirow{2}{*}{ 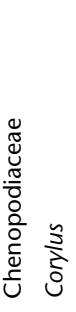 } & \multirow[t]{2}{*}{ 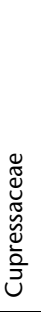 } & \multirow[t]{2}{*}{ 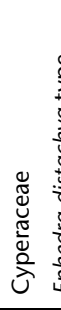 } & \multirow[t]{2}{*}{ 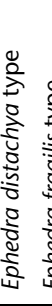 } & \multirow{2}{*}{ 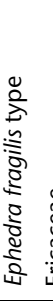 } & \multirow{2}{*}{. } & \multirow{2}{*}{ 苋 } & \multirow{2}{*}{\multicolumn{2}{|c|}{ 离 }} & \multirow{2}{*}{ 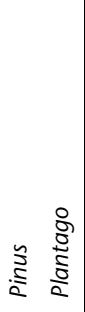 } & \multirow{2}{*}{\multicolumn{3}{|c|}{ 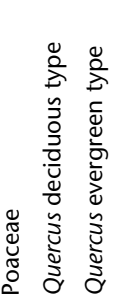 }} & \multirow{2}{*}{\multicolumn{2}{|c|}{ 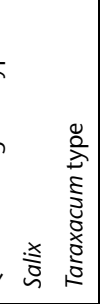 }} & \multirow[t]{2}{*}{ 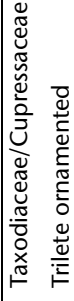 } \\
\hline & Top & Bottom & & & & & & & & & & & & & & & & & & & & & & & & & \\
\hline $\begin{array}{l}\text { 339-U1391A- } \\
1 \mathrm{H}-\mathrm{CC}\end{array}$ & 4.11 & 4.16 & $\mathrm{M}$ & A & & $\mathrm{F}$ & & A $F$ & & C & & A & & & C & C & & & & & A & C & & & $\mathrm{F}$ & $\mathrm{F}$ & \\
\hline $7 \mathrm{H}-\mathrm{CC}$ & 61.66 & 61.71 & $G$ & A & & C & & C C & & $\mathrm{F}$ & & C & & $\mathrm{F}$ & & & C & A & C & & A & & A & $\mathrm{F}$ & & A & \\
\hline $14 \mathrm{H}-\mathrm{CC}$ & 128.14 & 128.19 & G & A & $F$ & & $\mathrm{~F} C$ & C C & & C & & A & $\mathrm{F}$ & $\mathrm{F}$ & & C & A & C & C & $\mathrm{F} \quad \mathrm{C}$ & C & C & A & C & & A & \\
\hline $21 \mathrm{X}-\mathrm{CC}$ & 189.22 & 189.27 & G & A & & & & $\mathrm{F} \quad \mathrm{F}$ & & & & C & $\mathrm{F}$ & & $\mathrm{F}$ & & C & A & $\mathrm{F}$ & & C & $\mathrm{F}$ & C & $\mathrm{F}$ & & A & $\mathrm{F}$ \\
\hline $28 \mathrm{X}-\mathrm{CC}$ & 256.92 & 256.97 & $\mathrm{M}$ & A & & & $C \mathrm{C}$ & C C & & $\mathrm{F}$ & $\mathrm{F}$ & A & & $\mathrm{F}$ & C & & $\mathrm{F}$ & C & C & & A & C & C & & & A & \\
\hline $35 \mathrm{X}-\mathrm{CC}$ & 324.39 & 324.44 & $P$ & A & & A & A A & A A & A & & A & A & & & A & A & & A & & & A & A & A & & & A & \\
\hline 339-U1391 & & & & & & & & & & & & & & & & & & & & & & & & & & & \\
\hline $5 \mathrm{R}-\mathrm{CC}$ & 374.48 & 374.53 & $\mathrm{M}$ & A & & & $\mathrm{F} C$ & C & & $\mathrm{F}$ & $\mathrm{F}$ & $\mathrm{F}$ & & & & $\mathrm{F}$ & C & $\mathrm{F}$ & & & A & $C$ & C & & & A & $\mathrm{F}$ \\
\hline $15 \mathrm{R}-\mathrm{CC}$ & 470.31 & 470.36 & $\mathrm{P}$ & A & & $\mathrm{F}$ & $\mathrm{FCC}$ & $C \mathrm{C}$ & & & & A & & & $\mathrm{F}$ & $\mathrm{F}$ & C & $\mathrm{F}$ & & & $C \mathrm{~F}$ & $\mathrm{~F}$ & $\mathrm{~F}$ & $\mathrm{~F}$ & & A & \\
\hline
\end{tabular}

Group preservation: $\mathrm{G}=$ good, $\mathrm{M}=$ medium, $\mathrm{P}=$ poor. Group abundance: $\mathrm{A}=$ abundant, $\mathrm{C}=$ common, $\mathrm{F}=$ few. See "Biostratigraphy" in the "Methods" chapter (Expedition 339 Scientists, 2013b) for abundance and preservation definitions. 
Table T9. FlexIt tool core orientation data, Site U1391.

\begin{tabular}{crc}
\hline Core & $\begin{array}{c}\text { Orientation } \\
\text { angle }\left(^{\circ}\right)\end{array}$ & $\begin{array}{c}\text { Orientation } \\
\text { standard } \\
\text { deviation }\left(^{\circ}\right)\end{array}$ \\
\hline $339-U 1391 \mathrm{~A}-$ & & \\
$4 \mathrm{H}$ & 218 & 0.27 \\
$5 \mathrm{H}$ & 70 & 0.08 \\
$6 \mathrm{H}$ & 176 & 0.33 \\
$7 \mathrm{H}$ & 132 & 0.28 \\
$8 \mathrm{H}$ & 236 & 0.14 \\
$9 \mathrm{H}$ & 178 & 0.07 \\
$10 \mathrm{H}$ & 50 & 0.28 \\
$11 \mathrm{H}$ & 214 & 0.10 \\
$12 \mathrm{H}$ & 348 & 0.03 \\
$13 \mathrm{H}$ & 337 & 0.14 \\
$14 \mathrm{H}$ & 41 & 0.48 \\
$15 \mathrm{H}$ & 280 & 0.10 \\
$16 \mathrm{H}$ & 348 & 0.41 \\
$17 \mathrm{H}$ & 74 & 0.01 \\
$18 \mathrm{H}$ & 197 & 0.07 \\
$19 \mathrm{H}$ & 242 & 0.02 \\
$339-\mathrm{U} 1391 \mathrm{~B}-$ & & \\
$3 \mathrm{H}$ & 16 & 0.21 \\
$4 \mathrm{H}$ & 305 & 1.82 \\
$5 \mathrm{H}$ & 224 & 0.59 \\
$6 \mathrm{H}$ & 258 & 0.03 \\
$7 \mathrm{H}$ & 66 & 0.13 \\
$8 \mathrm{H}$ & 333 & 1.22 \\
$9 \mathrm{H}$ & 233 & 0.03 \\
$10 \mathrm{H}$ & 327 & 0.12 \\
$11 \mathrm{H}$ & 331 & 0.02 \\
$12 \mathrm{H}$ & 261 & 0.00 \\
$13 \mathrm{H}$ & 84 & 0.24 \\
$14 \mathrm{H}$ & 171 & 0.04 \\
$15 \mathrm{H}$ & 39 & 0.02 \\
$16 \mathrm{H}$ & 59 & 0.05 \\
$17 \mathrm{H}$ & 153 & 0.02 \\
$18 \mathrm{H}$ & 319 & 0.11 \\
\hline & &
\end{tabular}


Table T10. NRM inclination, declination, and intensity data after $20 \mathrm{mT}$ peak field AF demagnetization, Hole U1391A.

\begin{tabular}{|c|c|c|c|c|c|}
\hline $\begin{array}{l}\text { Core, section, } \\
\text { interval }(\mathrm{cm})\end{array}$ & $\begin{array}{l}\text { Depth } \\
\text { (mbsf) }\end{array}$ & $\begin{array}{c}\text { Inclination } \\
\left({ }^{\circ}\right)\end{array}$ & $\begin{array}{l}\text { Declination } \\
\left({ }^{\circ}\right)\end{array}$ & $\begin{array}{c}\text { FlexIt- } \\
\text { corrected } \\
\text { declination } \\
\left({ }^{\circ}\right)\end{array}$ & $\begin{array}{l}\text { Intensity } \\
(\mathrm{A} / \mathrm{m})\end{array}$ \\
\hline \multicolumn{6}{|l|}{ 339-U1391A- } \\
\hline $1 \mathrm{H}-1$ & 0.00 & & & & \\
\hline $1 \mathrm{H}-1,5$ & 0.05 & & & & \\
\hline $1 \mathrm{H}-1,10$ & 0.10 & & & & \\
\hline $1 \mathrm{H}-1,15$ & 0.15 & & & & \\
\hline $1 \mathrm{H}-1,20$ & 0.20 & & & & \\
\hline $1 \mathrm{H}-1,25$ & 0.25 & & & & \\
\hline $1 \mathrm{H}-1,30$ & 0.30 & & & & \\
\hline $1 \mathrm{H}-1,35$ & 0.35 & 60.2 & 228.2 & & 0.014022 \\
\hline $1 \mathrm{H}-1,40$ & 0.40 & 58.3 & 230.1 & & 0.012544 \\
\hline $1 \mathrm{H}-1,45$ & 0.45 & 59.5 & 220 & & 0.011093 \\
\hline $1 \mathrm{H}-1,50$ & 0.50 & 56.9 & 205.1 & & 0.011461 \\
\hline $1 \mathrm{H}-1,55$ & 0.55 & 56.5 & 203.6 & & 0.013273 \\
\hline $1 \mathrm{H}-1,60$ & 0.60 & 48.9 & 215.9 & & 0.015693 \\
\hline $1 \mathrm{H}-1,65$ & 0.65 & 49.3 & 219.5 & & 0.017084 \\
\hline $1 \mathrm{H}-1,70$ & 0.70 & 52.5 & 221.1 & & 0.017791 \\
\hline $1 \mathrm{H}-1,75$ & 0.75 & 57.5 & 220.1 & & 0.019657 \\
\hline $1 \mathrm{H}-1,80$ & 0.80 & 59.6 & 216 & & 0.02317 \\
\hline $1 \mathrm{H}-1,85$ & 0.85 & 62.5 & 217 & & 0.025647 \\
\hline $1 \mathrm{H}-1,90$ & 0.90 & 61.6 & 220.8 & & 0.028343 \\
\hline $1 \mathrm{H}-1,95$ & 0.95 & 63.3 & 220.7 & & 0.027091 \\
\hline $1 \mathrm{H}-1,100$ & 1.00 & 65.5 & 216.5 & & 0.025337 \\
\hline $1 \mathrm{H}-1,105$ & 1.05 & 63 & 216.1 & & 0.02595 \\
\hline $1 \mathrm{H}-1,110$ & 1.10 & 61.5 & 216.6 & & 0.025611 \\
\hline $1 \mathrm{H}-1,115$ & 1.15 & 61.1 & 212.8 & & 0.025078 \\
\hline $1 \mathrm{H}-1,120$ & 1.20 & 61.3 & 181 & & 0.024382 \\
\hline $1 \mathrm{H}-1,125$ & 1.25 & 58.9 & 166.3 & & 0.0255 \\
\hline $1 \mathrm{H}-1,130$ & 1.30 & 58.9 & 167 & & 0.026128 \\
\hline $1 \mathrm{H}-1,135$ & 1.35 & 58.2 & 161.4 & & 0.025444 \\
\hline $1 \mathrm{H}-1,140$ & 1.40 & & & & \\
\hline $1 \mathrm{H}-1,145$ & 1.45 & & & & \\
\hline $1 \mathrm{H}-1,150$ & 1.50 & & & & \\
\hline $1 \mathrm{H}-2$ & 1.50 & & & & \\
\hline $1 \mathrm{H}-2,5$ & 1.55 & & & & \\
\hline $1 \mathrm{H}-2,10$ & 1.60 & & & & \\
\hline $1 \mathrm{H}-2,15$ & 1.65 & 60.7 & 197.7 & & 0.023061 \\
\hline $1 \mathrm{H}-2,20$ & 1.70 & 62.5 & 196.8 & & 0.020941 \\
\hline $1 \mathrm{H}-2,25$ & 1.75 & 62.5 & 190.4 & & 0.020306 \\
\hline $1 \mathrm{H}-2,30$ & 1.80 & 61.2 & 187.4 & & 0.020883 \\
\hline $1 \mathrm{H}-2,35$ & 1.85 & 62 & 187.3 & & 0.020945 \\
\hline $1 \mathrm{H}-2,40$ & 1.90 & 60 & 189.5 & & 0.021987 \\
\hline $1 \mathrm{H}-2,45$ & 1.95 & 61.8 & 190.7 & & 0.022358 \\
\hline $1 \mathrm{H}-2,50$ & 2.00 & 66.3 & 187 & & 0.023267 \\
\hline $1 \mathrm{H}-2,55$ & 2.05 & 63.4 & 185.2 & & 0.026009 \\
\hline $1 \mathrm{H}-2,60$ & 2.10 & 62.7 & 185.6 & & 0.027397 \\
\hline $1 \mathrm{H}-2,65$ & 2.15 & 62.7 & 184.5 & & 0.027284 \\
\hline $1 \mathrm{H}-2,70$ & 2.20 & 59.5 & 185.1 & & 0.028287 \\
\hline $1 \mathrm{H}-2,75$ & 2.25 & 63.8 & 184.3 & & 0.027107 \\
\hline $1 \mathrm{H}-2,80$ & 2.30 & 66.4 & 182.5 & & 0.026874 \\
\hline $1 \mathrm{H}-2,85$ & 2.35 & 64.7 & 190 & & 0.027951 \\
\hline $1 \mathrm{H}-2,90$ & 2.40 & 67 & 189.5 & & 0.026269 \\
\hline $1 \mathrm{H}-2,95$ & 2.45 & 65.1 & 187.4 & & 0.025956 \\
\hline $1 \mathrm{H}-2,100$ & 2.50 & 62 & 188.9 & & 0.025714 \\
\hline $1 \mathrm{H}-2,105$ & 2.55 & 65 & 187 & & 0.023933 \\
\hline $1 \mathrm{H}-2,110$ & 2.60 & 62.4 & 184.5 & & 0.025918 \\
\hline $1 \mathrm{H}-2,115$ & 2.65 & 62 & 181.4 & & 0.026268 \\
\hline $1 \mathrm{H}-2,120$ & 2.70 & 63.5 & 180 & & 0.02569 \\
\hline
\end{tabular}

Blank cells indicate depth levels where data were either not available (i.e., Flexlt-corrected declination data for nonoriented cores) or removed because of disturbance, voids, or measurement edge effects. Only a portion of this table appears here. The complete table is available in ASCII. 
Table T11. NRM inclination, declination, and intensity data after $20 \mathrm{mT}$ peak field AF demagnetization, Hole U1391B.

\begin{tabular}{|c|c|c|c|c|c|}
\hline $\begin{array}{l}\text { Core, section, } \\
\text { interval }(\mathrm{cm})\end{array}$ & $\begin{array}{l}\text { Depth } \\
\text { (mbsf) }\end{array}$ & $\begin{array}{c}\text { Inclination } \\
\left(^{\circ}\right)\end{array}$ & $\begin{array}{l}\text { Declination } \\
\left({ }^{\circ}\right)\end{array}$ & $\begin{array}{c}\text { Flexlt- } \\
\text { corrected } \\
\text { declination } \\
\left({ }^{\circ}\right)\end{array}$ & $\begin{array}{l}\text { Intensity } \\
(\mathrm{A} / \mathrm{m})\end{array}$ \\
\hline \multicolumn{6}{|l|}{ 339-U1391B- } \\
\hline $1 \mathrm{H}-1$ & 0.00 & & & & \\
\hline $1 \mathrm{H}-1,5$ & 0.05 & & & & \\
\hline $1 \mathrm{H}-1,10$ & 0.10 & & & & \\
\hline $1 \mathrm{H}-1,15$ & 0.15 & 86.5 & 293.9 & & 0.04883 \\
\hline $1 \mathrm{H}-1,20$ & 0.20 & 83.3 & 354.6 & & 0.049121 \\
\hline $1 \mathrm{H}-1,25$ & 0.25 & 77.1 & 349.6 & & 0.041406 \\
\hline $1 \mathrm{H}-1,30$ & 0.30 & 69 & 349.1 & & 0.037523 \\
\hline $1 \mathrm{H}-1,35$ & 0.35 & 65.4 & 351.4 & & 0.038743 \\
\hline $1 \mathrm{H}-1,40$ & 0.40 & 68.9 & 352.8 & & 0.037628 \\
\hline $1 \mathrm{H}-1,45$ & 0.45 & 73.2 & 348.4 & & 0.033997 \\
\hline $1 \mathrm{H}-1,50$ & 0.50 & 68.8 & 355.4 & & 0.034376 \\
\hline $1 \mathrm{H}-1,55$ & 0.55 & 65.1 & 356.2 & & 0.035328 \\
\hline $1 \mathrm{H}-1,60$ & 0.60 & 63.1 & 350 & & 0.03269 \\
\hline $1 \mathrm{H}-1,65$ & 0.65 & 61.4 & 351.1 & & 0.029744 \\
\hline $1 \mathrm{H}-1,70$ & 0.70 & 60.8 & 352.8 & & 0.028656 \\
\hline $1 \mathrm{H}-1,75$ & 0.75 & 60.9 & 349 & & 0.027649 \\
\hline $1 \mathrm{H}-1,80$ & 0.80 & 60.8 & 347.9 & & 0.025769 \\
\hline $1 \mathrm{H}-1,85$ & 0.85 & 60.2 & 349.8 & & 0.023994 \\
\hline $1 \mathrm{H}-1,90$ & 0.90 & 61.4 & 354.8 & & 0.022075 \\
\hline $1 \mathrm{H}-1,95$ & 0.95 & 62.9 & 355.1 & & 0.019893 \\
\hline $1 \mathrm{H}-1,100$ & 1.00 & 61.4 & 353.1 & & 0.018273 \\
\hline $1 \mathrm{H}-1,105$ & 1.05 & 58.3 & 350.9 & & 0.018538 \\
\hline $1 \mathrm{H}-1,110$ & 1.10 & 53.7 & 350.6 & & 0.019631 \\
\hline $1 \mathrm{H}-1,115$ & 1.15 & 55.2 & 349.7 & & 0.020174 \\
\hline $1 \mathrm{H}-1,120$ & 1.20 & 58.3 & 349.2 & & 0.020879 \\
\hline $1 \mathrm{H}-1,125$ & 1.25 & 58.4 & 349.1 & & 0.022429 \\
\hline $1 \mathrm{H}-1,130$ & 1.30 & 54.4 & 348.8 & & 0.024558 \\
\hline $1 \mathrm{H}-1,135$ & 1.35 & 53.8 & 346.1 & & 0.024804 \\
\hline $1 \mathrm{H}-1,140$ & 1.40 & & & & \\
\hline $1 \mathrm{H}-1,145$ & 1.45 & & & & \\
\hline $1 \mathrm{H}-1,150$ & 1.50 & & & & \\
\hline $1 \mathrm{H}-2$ & 1.51 & & & & \\
\hline $1 \mathrm{H}-2,5$ & 1.56 & & & & \\
\hline $1 \mathrm{H}-2,10$ & 1.61 & & & & \\
\hline $1 \mathrm{H}-2,15$ & 1.66 & 60.3 & 359.4 & & 0.02619 \\
\hline $1 \mathrm{H}-2,20$ & 1.71 & 60.2 & 0.8 & & 0.026749 \\
\hline $1 \mathrm{H}-2,25$ & 1.76 & 60.7 & 357.9 & & 0.026308 \\
\hline $1 \mathrm{H}-2,30$ & 1.81 & 59.9 & 357.3 & & 0.026556 \\
\hline $1 \mathrm{H}-2,35$ & 1.86 & 59.3 & 1.6 & & 0.027718 \\
\hline $1 \mathrm{H}-2,40$ & 1.91 & 57.3 & 0.5 & & 0.029682 \\
\hline $1 \mathrm{H}-2,45$ & 1.96 & 56 & 0.7 & & 0.030459 \\
\hline $1 \mathrm{H}-2,50$ & 2.01 & 56.9 & 1.2 & & 0.029949 \\
\hline $1 \mathrm{H}-2,55$ & 2.06 & 57.1 & 1.3 & & 0.029788 \\
\hline $1 \mathrm{H}-2,60$ & 2.11 & 55.7 & 0.1 & & 0.03015 \\
\hline $1 \mathrm{H}-2,65$ & 2.16 & 53.5 & 1.7 & & 0.031393 \\
\hline $1 \mathrm{H}-2,70$ & 2.21 & 52.4 & 4.4 & & 0.032268 \\
\hline $1 \mathrm{H}-2,75$ & 2.26 & 52.4 & 6.6 & & 0.032296 \\
\hline $1 \mathrm{H}-2,80$ & 2.31 & 52.1 & 8.7 & & 0.032217 \\
\hline $1 \mathrm{H}-2,85$ & 2.36 & 50.8 & 11.1 & & 0.032548 \\
\hline $1 \mathrm{H}-2,90$ & 2.41 & 48.5 & 12.6 & & 0.033827 \\
\hline $1 \mathrm{H}-2,95$ & 2.46 & 49.3 & 11.4 & & 0.033962 \\
\hline $1 \mathrm{H}-2,100$ & 2.51 & 50.3 & 6.6 & & 0.03335 \\
\hline $1 \mathrm{H}-2,105$ & 2.56 & 49 & 7.7 & & 0.033129 \\
\hline $1 \mathrm{H}-2,110$ & 2.61 & 48.6 & 10.9 & & 0.03329 \\
\hline $1 \mathrm{H}-2,115$ & 2.66 & 52.6 & 14.9 & & 0.031722 \\
\hline $1 \mathrm{H}-2,120$ & 2.71 & 52.4 & 17.7 & & 0.030419 \\
\hline
\end{tabular}

Blank cells indicate depth levels where data were either not available (i.e., Flexlt-corrected declination data for nonoriented cores) or removed because of disturbance, voids, or measurement edge effects. Only a portion of this table appears here. The complete table is available in ASCII. 
Table T12. NRM inclination, declination, and intensity data after $20 \mathrm{mT}$ peak field AF demagnetization, Hole U1391C.

\begin{tabular}{|c|c|c|c|c|c|}
\hline $\begin{array}{l}\text { Core, section, } \\
\text { interval }(\mathrm{cm})\end{array}$ & $\begin{array}{l}\text { Depth } \\
\text { (mbsf) }\end{array}$ & $\begin{array}{c}\text { Inclination } \\
\left(^{\circ}\right)\end{array}$ & $\begin{array}{c}\text { Declination } \\
\left(^{\circ}\right)\end{array}$ & $\begin{array}{c}\text { Flexlt- } \\
\text { corrected } \\
\text { declination } \\
\left({ }^{\circ}\right)\end{array}$ & $\begin{array}{l}\text { Intensity } \\
(\mathrm{A} / \mathrm{m})\end{array}$ \\
\hline \multicolumn{6}{|l|}{ 339-U1391C- } \\
\hline $2 \mathrm{R}-1$ & 340.00 & & & & \\
\hline $2 \mathrm{R}-1,5$ & 340.05 & & & & \\
\hline $2 \mathrm{R}-1,10$ & 340.10 & & & & \\
\hline $2 \mathrm{R}-1,15$ & 340.15 & -9.8 & 84.6 & & 0.001456 \\
\hline $2 \mathrm{R}-1,20$ & 340.20 & -10.4 & 86.3 & & 0.001361 \\
\hline $2 \mathrm{R}-1,25$ & 340.25 & -8.5 & 92.6 & & 0.001251 \\
\hline $2 \mathrm{R}-1,30$ & 340.30 & -8.6 & 94.6 & & 0.0007586 \\
\hline $2 \mathrm{R}-1,35$ & 340.35 & 8.2 & 101.3 & & 0.001021 \\
\hline $2 \mathrm{R}-1,40$ & 340.40 & -9.5 & 109.4 & & 0.0005744 \\
\hline $2 \mathrm{R}-1,45$ & 340.45 & -21.4 & 114.8 & & 0.001065 \\
\hline $2 \mathrm{R}-1,50$ & 340.50 & -35.9 & 118.1 & & 0.001159 \\
\hline $2 \mathrm{R}-1,55$ & 340.55 & -41 & 107.4 & & 0.001083 \\
\hline $2 \mathrm{R}-1,60$ & 340.60 & -32.1 & 104.6 & & 0.001118 \\
\hline $2 \mathrm{R}-1,65$ & 340.65 & -28.9 & 85.5 & & 0.0009874 \\
\hline $2 \mathrm{R}-1,70$ & 340.70 & -24.4 & 83 & & 0.0008581 \\
\hline $2 \mathrm{R}-1,75$ & 340.75 & -15.9 & 99.2 & & 0.0009338 \\
\hline $2 \mathrm{R}-1,80$ & 340.80 & -18 & 101.4 & & 0.0009876 \\
\hline $2 \mathrm{R}-1,85$ & 340.85 & -26 & 82.8 & & 0.0008152 \\
\hline $2 \mathrm{R}-1,90$ & 340.90 & -24.5 & 66.6 & & 0.001002 \\
\hline $2 \mathrm{R}-1,95$ & 340.95 & -25.5 & 80.4 & & 0.001089 \\
\hline $2 \mathrm{R}-1,100$ & 341.00 & -32.2 & 113.9 & & 0.000854 \\
\hline $2 \mathrm{R}-1,105$ & 341.05 & -19.9 & 108.2 & & 0.0008253 \\
\hline $2 \mathrm{R}-1,110$ & 341.10 & -14.2 & 92.8 & & 0.001024 \\
\hline $2 \mathrm{R}-1,115$ & 341.15 & -15.3 & 88.6 & & 0.001103 \\
\hline $2 \mathrm{R}-1,120$ & 341.20 & -19.8 & 103.3 & & 0.0009573 \\
\hline $2 \mathrm{R}-1,125$ & 341.25 & -40 & 170.7 & & 0.0005689 \\
\hline $2 \mathrm{R}-1,130$ & 341.30 & 22.3 & 7.1 & & 0.001285 \\
\hline $2 \mathrm{R}-1,135$ & 341.35 & 38.1 & 44.7 & & 0.001194 \\
\hline $2 \mathrm{R}-1,140$ & 341.40 & & & & \\
\hline $2 \mathrm{R}-1,145$ & 341.45 & & & & \\
\hline $2 \mathrm{R}-1,150$ & 341.50 & & & & \\
\hline $2 \mathrm{R}-2$ & 341.50 & & & & \\
\hline $2 \mathrm{R}-2,5$ & 341.55 & & & & \\
\hline $2 \mathrm{R}-2,10$ & 341.60 & & & & \\
\hline $2 \mathrm{R}-2,15$ & 341.65 & -35.6 & 260.1 & & 0.001255 \\
\hline $2 \mathrm{R}-2,20$ & 341.70 & -43.1 & 309.6 & & 0.001073 \\
\hline $2 \mathrm{R}-2,25$ & 341.75 & -48.5 & 328.2 & & 0.000859 \\
\hline $2 \mathrm{R}-2,30$ & 341.80 & -57 & 269.4 & & 0.0005821 \\
\hline $2 \mathrm{R}-2,35$ & 341.85 & -55.4 & 217 & & 0.0003853 \\
\hline $2 \mathrm{R}-2,40$ & 341.90 & -68.2 & 59.3 & & 0.0002504 \\
\hline $2 \mathrm{R}-2,45$ & 341.95 & -47.2 & 320.3 & & 0.0003222 \\
\hline $2 \mathrm{R}-2,50$ & 342.00 & -42.2 & 309.5 & & 0.0004406 \\
\hline $2 \mathrm{R}-2,55$ & 342.05 & -63 & 351.4 & & 0.0004026 \\
\hline $2 \mathrm{R}-2,60$ & 342.10 & -73.2 & 267.1 & & 0.0004312 \\
\hline $2 R-2,65$ & 342.15 & -45.8 & 238.8 & & 0.0008045 \\
\hline $2 \mathrm{R}-2,70$ & 342.20 & -44.3 & 270.5 & & 0.001238 \\
\hline $2 \mathrm{R}-2,75$ & 342.25 & -64 & 264.1 & & 0.0008406 \\
\hline $2 \mathrm{R}-2,80$ & 342.30 & -30.9 & 57.8 & & 0.0007789 \\
\hline $2 \mathrm{R}-2,85$ & 342.35 & -2.2 & 7.4 & & 0.000577 \\
\hline $2 \mathrm{R}-2,90$ & 342.40 & -28.5 & 270.4 & & 0.0006048 \\
\hline $2 \mathrm{R}-2,95$ & 342.45 & -38.1 & 250.3 & & 0.0006385 \\
\hline $2 \mathrm{R}-2,100$ & 342.50 & -47.2 & 246.1 & & 0.0005717 \\
\hline $2 \mathrm{R}-2,105$ & 342.55 & -64.4 & 281.7 & & 0.0004235 \\
\hline $2 \mathrm{R}-2,110$ & 342.60 & -59.9 & 248.3 & & 0.0003664 \\
\hline $2 \mathrm{R}-2,115$ & 342.65 & -67.4 & 184.1 & & 0.00034 \\
\hline $2 \mathrm{R}-2,120$ & 342.70 & -75.3 & 297.9 & & 0.0002106 \\
\hline
\end{tabular}

Blank cells indicate depth levels where data were either not available (i.e., Flexlt-corrected declination data for nonoriented cores) or removed because of disturbance, voids, or measurement edge effects. Only a portion of this table appears here. The complete table is available in ASCII. 
Table T13. Polarity boundaries, Site U1391.

\begin{tabular}{lcccc}
\hline & & \multicolumn{3}{c}{ Depth (mbsf) } \\
\cline { 3 - 5 } Polarity boundary & $\begin{array}{c}\text { Age } \\
(\mathrm{Ma})\end{array}$ & $\begin{array}{c}\text { Hole } \\
\text { U1391A }\end{array}$ & $\begin{array}{c}\text { Hole } \\
\text { U1391B }\end{array}$ & $\begin{array}{c}\text { Hole } \\
\text { U1391C }\end{array}$ \\
\hline Brunhes/Matuyama & 0.781 & Below 175 & Below 175 \\
T Olduvai & 1.778 & & & $452-463$ \\
B Olduvai & 1.945 & & & 486 \\
Matuyama/Gauss & 2.581 & & & 575 \\
\hline
\end{tabular}

$\mathrm{T}=$ top, $\mathrm{B}=$ bottom 
Table T14. Headspace sample hydrocarbon concentrations, Holes U1391A and U1391C.

\begin{tabular}{|c|c|c|c|c|c|c|}
\hline \multirow{2}{*}{$\begin{array}{l}\text { Core, } \\
\text { section }\end{array}$} & \multirow{2}{*}{$\begin{array}{l}\text { Depth } \\
\text { (mbsf) }\end{array}$} & \multicolumn{5}{|c|}{ Concentration (ppmv) } \\
\hline & & Methane & Ethene & Ethane & Propene & Propane \\
\hline \multicolumn{7}{|l|}{ 339-U1391A- } \\
\hline $1 \mathrm{H}-3$ & 3.00 & 5.43 & - & - & - & - \\
\hline $2 \mathrm{H}-7$ & 13.00 & 3.98 & - & - & - & - \\
\hline $3 \mathrm{H}-7$ & 22.41 & $2,494.22$ & - & - & - & - \\
\hline $4 \mathrm{H}-7$ & 32.10 & $13,605.65$ & - & 0.45 & - & - \\
\hline $5 \mathrm{H}-7$ & 41.60 & $23,483.6$ & 0.53 & 0.69 & - & - \\
\hline $6 \mathrm{H}-7$ & 51.15 & $36,354.05$ & - & 0.84 & 0.61 & - \\
\hline $7 \mathrm{H}-7$ & 60.73 & $26,225.48$ & - & 0.88 & 0.47 & 0.31 \\
\hline $8 \mathrm{H}-7$ & 69.91 & $41,703.97$ & 0.72 & 2.02 & - & - \\
\hline $9 \mathrm{H}-7$ & 79.36 & $16,198.78$ & 0.81 & 1.23 & - & - \\
\hline $10 \mathrm{H}-7$ & 88.65 & $9,855.19$ & - & 1.63 & - & - \\
\hline $12 \mathrm{H}-8$ & 107.94 & $6,405.11$ & - & - & - & - \\
\hline $13 \mathrm{H}-8$ & 117.77 & $6,028.83$ & 1 & 0.81 & 0.33 & 0.32 \\
\hline $14 \mathrm{H}-7$ & 126.70 & $6,277.29$ & - & 0.88 & - & - \\
\hline $15 \mathrm{H}-7$ & 136.05 & $8,973.06$ & - & 1.06 & 0.3 & - \\
\hline $16 \mathrm{H}-8$ & 146.28 & $12,022.39$ & 0.59 & 0.81 & 0.37 & - \\
\hline $17 \mathrm{H}-7$ & 155.16 & $9,349.06$ & - & 0.92 & - & - \\
\hline $18 \mathrm{H}-8$ & 165.43 & $12,358.28$ & 1.66 & 1.67 & - & - \\
\hline $20 X-5$ & 177.10 & $13,139.37$ & 1 & 1.63 & - & - \\
\hline $21 X-5$ & 186.63 & $11,539.07$ & 0.71 & 1.44 & - & - \\
\hline $22 X-4$ & 193.75 & $7,474.79$ & 0.53 & 0.92 & - & - \\
\hline $23 X-4$ & 204.30 & $7,022.86$ & 1.1 & 2 & - & - \\
\hline $25 X-4$ & 223.50 & $9,415.01$ & 0.89 & 1.83 & - & 0.34 \\
\hline $26 X-6$ & 234.90 & $13,225.2$ & 0.78 & 2.12 & - & - \\
\hline $27 X-3$ & 241.20 & $6,758.85$ & 0.51 & 0.79 & - & 0.35 \\
\hline $28 X-4$ & 252.31 & $20,642.64$ & 1.75 & 2.32 & - & - \\
\hline $29 X-4$ & 261.85 & $7,807.1$ & 0.76 & 2.23 & 0.37 & 0.34 \\
\hline $30 X-4$ & 271.02 & $6,120.59$ & - & 0.94 & - & - \\
\hline $31 X-3$ & 279.61 & $4,957.69$ & - & 0.74 & - & - \\
\hline $32 X-4$ & 290.19 & $8,901.46$ & 1.22 & 1.82 & - & - \\
\hline $33 X-3$ & 298.80 & $6,208.26$ & 1.07 & 2.1 & - & 0.7 \\
\hline $34 X-4$ & 309.60 & $5,862.39$ & 0.47 & 1.03 & - & 0.36 \\
\hline $35 X-7$ & 322.56 & $9,907.35$ & 0.81 & 1.83 & - & - \\
\hline $36 X-7$ & 332.84 & $6,349.51$ & - & 0.85 & 0.32 & 0.54 \\
\hline $38 \times-6$ & 350.91 & $3,096.61$ & - & 0.74 & - & - \\
\hline \multicolumn{7}{|l|}{ 339-U1391C- } \\
\hline $3 R-4$ & 350.00 & $7,884.27$ & 1.79 & 3.29 & - & - \\
\hline $4 \mathrm{R}-2$ & 356.60 & $3,600.97$ & - & 1.03 & - & - \\
\hline $5 R-4$ & 369.20 & $11,617.39$ & 0.7 & 2.55 & - & - \\
\hline $6 \mathrm{R}-2$ & 375.80 & $6,535.09$ & 0.76 & 1.89 & - & - \\
\hline $7 R-4$ & 388.40 & $8,039.93$ & 0.42 & 2.31 & 0.32 & 0.43 \\
\hline $8 \mathrm{R}-3$ & 396.50 & 6,864 & 0.55 & 1.57 & - & 0.56 \\
\hline $9 \mathrm{R}-6$ & 410.50 & $5,506.78$ & 1.19 & 4.74 & - & - \\
\hline $10 R-5$ & 418.60 & $2,807.05$ & 0.48 & 1.32 & - & - \\
\hline $11 \mathrm{R}-6$ & 429.71 & $2,468.39$ & 0.75 & 0.41 & - & - \\
\hline $12 \mathrm{R}-7$ & 440.81 & $3,281.06$ & - & 0.67 & - & - \\
\hline 13R-7 & 450.30 & $6,411.36$ & - & 1.23 & - & - \\
\hline $14 \mathrm{R}-7$ & 459.91 & $1,627.41$ & 1.05 & - & - & - \\
\hline $15 \mathrm{R}-7$ & 468.75 & $2,087.48$ & 0.89 & 0.52 & - & - \\
\hline 16R-6 & 477.50 & $2,487.33$ & 0.87 & 0.62 & - & - \\
\hline 17R-3 & 482.70 & $7,445.49$ & 0.91 & 1.87 & - & - \\
\hline $18 \mathrm{R}-6$ & 496.50 & $8,057.85$ & 0.85 & 2.37 & - & 0.42 \\
\hline $19 \mathrm{R}-5$ & 504.60 & $4,827.74$ & 1.2 & 1.66 & - & 0.33 \\
\hline $20 \mathrm{R}-2$ & 509.60 & $5,064.61$ & - & 1.68 & - & - \\
\hline $21 \mathrm{R}-5$ & 523.70 & $3,655.72$ & 0.74 & 1.22 & - & - \\
\hline $22 \mathrm{R}-5$ & 533.30 & 4,400 & 1.27 & 2.22 & - & - \\
\hline $23 R-5$ & 543.02 & $14,689.29$ & 1.08 & 3.74 & - & 0.39 \\
\hline $24 R-5$ & 552.60 & $3,253.71$ & - & 1.04 & - & - \\
\hline 25R-7 & 565.20 & $3,510.22$ & 0.93 & 0.65 & - & - \\
\hline $27 R-6$ & 582.88 & $5,085.88$ & 1.11 & 2.59 & - & - \\
\hline 28R-7 & 594.00 & $4,055.11$ & - & 1.52 & 0.63 & - \\
\hline $30 \mathrm{R}-7$ & 613.20 & $3,752.66$ & 1.03 & 1.72 & 0.3 & - \\
\hline $31 \mathrm{R}-7$ & 622.51 & $3,007.5$ & 0.56 & 1.53 & 0.58 & - \\
\hline $32 \mathrm{R}-7$ & 632.40 & $1,062.85$ & 0.91 & 1.04 & 0.43 & - \\
\hline $33 R-6$ & 640.51 & $12,381.82$ & 2.59 & 7.17 & - & 4.76 \\
\hline $34 R-5$ & 648.60 & $7,763.52$ & 1.18 & 2.24 & - & 0.54 \\
\hline $36 \mathrm{R}-4$ & 666.30 & $1,276.15$ & 0.81 & 0.95 & - & - \\
\hline
\end{tabular}

$-=$ no data. 
Table T15. Results from coulometric and CHNS analysis on whole-round squeezecake samples, Hole U1391A.

\begin{tabular}{|c|c|c|c|c|c|c|c|}
\hline $\begin{array}{l}\text { Core, } \\
\text { section }\end{array}$ & $\begin{array}{l}\text { Depth } \\
\text { (mbsf) }\end{array}$ & $\begin{array}{l}\text { Calcium } \\
\text { carbonate } \\
\text { (wt\%) }\end{array}$ & $\begin{array}{c}\text { Inorganic } \\
\text { carbon } \\
(w t \%)\end{array}$ & $\begin{array}{l}\text { Total } \\
\text { carbon } \\
\text { (wt\%) }\end{array}$ & $\begin{array}{l}\text { Nitrogen } \\
\text { (wt\%) }\end{array}$ & $\begin{array}{l}\text { Organic } \\
\text { carbon } \\
\text { (wt\%) }\end{array}$ & $\mathrm{C} / \mathrm{N}$ \\
\hline \multicolumn{8}{|c|}{ 339-U1391A- } \\
\hline $1 \mathrm{H}-3$ & 3.75 & 27.321 & 3.276 & 4.19 & 0.08 & 0.91 & 11.38 \\
\hline $2 \mathrm{H}-6$ & 12.70 & 22.653 & 2.716 & 3.59 & 0.07 & 0.87 & 12.43 \\
\hline $3 \mathrm{H}-6$ & 22.25 & 21.987 & 2.636 & 3.45 & 0.09 & 0.81 & 9.00 \\
\hline $4 \mathrm{H}-6$ & 31.97 & 22.704 & 2.722 & 3.38 & 0.07 & 0.66 & 9.43 \\
\hline $5 \mathrm{H}-6$ & 41.49 & 26.718 & 3.203 & 3.93 & 0.07 & 0.73 & 10.43 \\
\hline $6 \mathrm{H}-6$ & 50.92 & 24.774 & 2.970 & 3.86 & 0.06 & 0.89 & 14.83 \\
\hline $7 \mathrm{H}-6$ & 60.67 & 31.517 & 3.779 & 4.68 & 0.08 & 0.9 & 11.25 \\
\hline $8 \mathrm{H}-6$ & 69.73 & 32.072 & 3.845 & 5.13 & 0.07 & 1.28 & 18.29 \\
\hline $9 \mathrm{H}-6$ & 79.23 & 45.256 & 5.426 & 6.82 & 0.08 & 1.39 & 17.38 \\
\hline $10 \mathrm{H}-6$ & 88.46 & 26.163 & 3.137 & 4.06 & 0.08 & 0.92 & 11.50 \\
\hline $11 \mathrm{H}-7$ & 99.16 & 26.438 & 3.170 & 3.70 & 0.06 & 0.53 & 8.83 \\
\hline $12 \mathrm{H}-6$ & 106.44 & 40.143 & 4.813 & 6.11 & 0.09 & 1.30 & 14.44 \\
\hline $13 \mathrm{H}-6$ & 116.55 & 23.072 & 2.766 & 3.25 & 0.06 & 0.48 & 8.00 \\
\hline $14 \mathrm{H}-6$ & 126.55 & 43.494 & 5.215 & 6.83 & 0.09 & 1.62 & 18.00 \\
\hline $15 \mathrm{H}-6$ & 135.92 & 29.486 & 3.535 & 4.58 & 0.07 & 1.04 & 14.86 \\
\hline $16 \mathrm{H}-6$ & 144.58 & 29.198 & 3.501 & 4.65 & 0.08 & 1.15 & 14.38 \\
\hline $17 \mathrm{H}-6$ & 154.98 & 30.479 & 3.654 & 4.58 & 0.07 & 0.93 & 13.29 \\
\hline $18 \mathrm{H}-6$ & 163.28 & 33.479 & 4.014 & 5.26 & 0.09 & 1.25 & 13.89 \\
\hline $19 \mathrm{H}-3$ & 169.52 & 23.402 & 2.806 & - & - & - & - \\
\hline $20 X-5$ & 178.45 & 17.559 & 2.105 & 3.90 & 0.08 & 1.79 & 22.38 \\
\hline $21 X-5$ & 187.77 & 36.813 & 4.414 & 5.77 & 0.09 & 1.36 & 15.11 \\
\hline $22 X-7$ & 198.56 & 34.836 & 4.177 & 5.48 & 0.07 & 1.3 & 18.57 \\
\hline $23 X-6$ & 207.76 & 26.212 & 3.143 & 4.16 & 0.07 & 1.02 & 14.57 \\
\hline $25 X-6$ & 226.74 & 23.330 & 2.797 & 3.62 & 0.08 & 0.82 & 10.25 \\
\hline $26 X-6$ & 236.17 & 23.727 & 2.845 & 3.60 & 0.08 & 0.76 & 9.50 \\
\hline $27 X-6$ & 245.94 & 18.899 & 2.266 & 2.98 & 0.08 & 0.71 & 8.88 \\
\hline $28 X-6$ & 254.95 & 21.038 & 2.522 & 3.35 & 0.09 & 0.83 & 9.22 \\
\hline $29 X-6$ & 265.15 & 30.533 & 3.661 & 4.64 & 0.09 & 0.98 & 10.89 \\
\hline $30 X-6$ & 275.13 & 30.150 & 3.615 & 4.72 & 0.09 & 1.11 & 12.33 \\
\hline $31 X-6$ & 283.21 & 27.810 & 3.334 & 4.17 & 0.09 & 0.84 & 9.33 \\
\hline $32 X-6$ & 294.41 & 21.415 & 2.568 & 3.05 & 0.07 & 0.48 & 6.86 \\
\hline $33 X-4$ & 301.53 & 23.516 & 2.820 & 3.60 & 0.08 & 0.78 & 9.75 \\
\hline $34 X-6$ & 313.85 & 19.649 & 2.356 & 3.05 & 0.09 & 0.69 & 7.67 \\
\hline $35 X-6$ & 322.05 & 30.700 & 3.681 & 4.78 & 0.10 & 1.10 & 11.00 \\
\hline $36 X-6$ & 332.71 & 20.579 & 2.467 & 3.27 & 0.09 & 0.80 & 8.89 \\
\hline $37 X-6$ & 341.37 & 22.836 & 2.738 & 3.41 & 0.08 & 0.67 & 8.38 \\
\hline $38 X-6$ & 351.66 & 28.027 & 3.360 & 4.23 & 0.09 & 0.87 & 9.67 \\
\hline
\end{tabular}

$-=$ no data. 
Table T16. Interstitial water major and minor elements, Site U1391. (Continued on next three pages.)

\begin{tabular}{|c|c|c|c|c|c|c|c|c|}
\hline $\begin{array}{l}\text { Core, section, } \\
\text { interval }(\mathrm{cm})\end{array}$ & $\begin{array}{l}\text { Depth } \\
\text { (mbsf) }\end{array}$ & $\begin{array}{c}\text { B }(\mu \mathrm{M}) \\
249.772 \mathrm{~nm} \\
\text { ICPAES }\end{array}$ & $\begin{array}{c}\mathrm{Ba}(\mu \mathrm{M}) \\
455.40 \mathrm{~nm} \\
\text { ICPAES }\end{array}$ & $\begin{array}{c}\mathrm{Fe}(\mu \mathrm{M}) \\
239.56 \mathrm{~nm} \\
\text { ICPAES }\end{array}$ & $\begin{array}{l}\mathrm{Li}(\mu \mathrm{M}) \\
670.78 \mathrm{~nm} \\
\text { ICPAES }\end{array}$ & $\begin{array}{c}\mathrm{Si}(\mu \mathrm{M}) \\
288.16 \mathrm{~nm} \\
\text { ICPAES }\end{array}$ & $\begin{array}{c}\mathrm{Sr}(\mu \mathrm{M}) \\
407.77 \mathrm{~nm} \\
\text { ICPAES }\end{array}$ & $\begin{array}{c}\text { Alkalinity } \\
\text { (meq/L) } \\
\text { TITRA_AUTO }\end{array}$ \\
\hline \multicolumn{9}{|l|}{ 339-U1391A- } \\
\hline $1 \mathrm{H}-2,145-150$ & 2.95 & 489.59 & 2.74 & 37.11 & 0.00 & 319.88 & 76.32 & 8.17 \\
\hline $2 \mathrm{H}-6,135-140$ & 12.95 & 553.92 & 2.82 & 13.20 & 0.00 & 251.82 & 61.87 & 15.82 \\
\hline $3 \mathrm{H}-6,126-131$ & 22.36 & 469.71 & 36.07 & 4.29 & 1.36 & 182.96 & 68.45 & 9.89 \\
\hline $4 \mathrm{H}-6,145-150$ & 32.05 & 450.89 & 28.79 & 2.38 & 1.02 & 202.84 & 69.64 & 7.72 \\
\hline $5 \mathrm{H}-6,145-150$ & 41.55 & 452.91 & 40.30 & 1.57 & 1.54 & 150.07 & 76.97 & 6.26 \\
\hline $6 \mathrm{H}-6,145-150$ & 51.10 & 413.42 & 34.11 & 7.56 & 1.27 & 231.39 & 79.16 & 6.95 \\
\hline 7H-5, 145-150 & 59.23 & 396.73 & 38.11 & 19.08 & 1.43 & 392.78 & 85.49 & 7.19 \\
\hline $8 \mathrm{H}-6,131-141$ & 69.79 & 400.54 & 38.92 & 14.46 & 1.52 & 178.41 & 83.50 & 5.96 \\
\hline $9 \mathrm{H}-6,136-141$ & 79.31 & 426.00 & 38.88 & 8.08 & 1.46 & 149.87 & 91.37 & 5.41 \\
\hline $10 \mathrm{H}-6,136-141$ & 88.60 & 405.11 & 35.55 & 18.32 & 1.33 & 247.97 & 86.69 & 6.72 \\
\hline $11 \mathrm{H}-6,135-140$ & 97.84 & 355.11 & 34.54 & 3.59 & 1.26 & 143.12 & 87.49 & 6.16 \\
\hline $12 \mathrm{H}-7,136-141$ & 107.89 & 354.18 & 32.18 & 3.97 & 1.13 & 190.57 & 86.55 & 6.92 \\
\hline $13 \mathrm{H}-7,105-110$ & 117.72 & 324.42 & 33.38 & 2.38 & 1.19 & 179.56 & 84.55 & 7.35 \\
\hline $14 \mathrm{H}-6,146-151$ & 126.66 & 335.94 & 35.14 & 3.33 & 1.27 & 255.79 & 85.45 & 8.24 \\
\hline $15 \mathrm{H}-6,126-131$ & 135.99 & 357.54 & 38.03 & 5.34 & 1.40 & 226.48 & 89.21 & 8.56 \\
\hline $16 \mathrm{H}-7,147-152$ & 146.23 & 257.08 & 46.22 & 1.63 & 1.76 & 235.98 & 87.86 & 8.24 \\
\hline $17 \mathrm{H}-6,137-142$ & 155.11 & 293.65 & 51.41 & 1.35 & 2.03 & 268.07 & 90.20 & 9.44 \\
\hline $18 \mathrm{H}-7,132-142$ & 165.33 & 295.68 & 54.23 & 3.32 & 2.16 & 308.92 & 88.16 & 8.63 \\
\hline $20 X-4,140-150$ & 177.00 & 294.52 & 55.63 & 2.63 & 2.22 & 309.35 & 92.72 & NA \\
\hline $21 X-4,133-143$ & 186.53 & 284.38 & 58.48 & 1.51 & 2.36 & 180.12 & 93.39 & NA \\
\hline $22 X-3,140-150$ & 193.65 & 257.63 & 60.75 & 1.49 & 2.46 & 234.18 & 98.11 & NA \\
\hline $23 X-3,140-150$ & 204.20 & 286.94 & 60.91 & 1.54 & 2.45 & 240.58 & 94.78 & NA \\
\hline $25 X-3,140-150$ & 223.40 & 246.57 & 65.49 & 1.56 & 2.70 & 272.24 & 99.84 & 6.96 \\
\hline $26 \mathrm{X}-5,140-150$ & 234.80 & 257.49 & 60.57 & 3.91 & 2.45 & 233.20 & 98.68 & 6.41 \\
\hline $27 X-2,140-150$ & 241.10 & 257.97 & 59.46 & 1.95 & 2.39 & 253.04 & 103.69 & 8.08 \\
\hline $28 X-3,140-150$ & 252.21 & 299.88 & 51.52 & 1.46 & 1.93 & 592.36 & 104.48 & 8.92 \\
\hline $29 X-3,134-144$ & 261.75 & 232.44 & 51.49 & 1.29 & 1.91 & 385.32 & 106.94 & 7.85 \\
\hline $30 X-3,140-150$ & 270.92 & 241.46 & 49.47 & 1.43 & 1.79 & 419.20 & 107.68 & 9.44 \\
\hline $31 \mathrm{X}-2,141-151$ & 279.51 & 208.81 & 50.24 & 1.46 & 1.84 & 312.71 & 105.26 & 7.19 \\
\hline $32 X-3,140-150$ & 290.09 & 230.06 & 49.86 & 1.92 & 1.86 & 338.54 & 103.26 & 6.89 \\
\hline $33 X-2,140-150$ & 298.70 & 216.39 & 51.64 & 7.48 & 1.98 & 501.61 & 106.97 & 7.97 \\
\hline $34 X-3,140-150$ & 309.50 & 262.31 & 52.76 & 3.43 & 2.02 & 241.70 & 111.99 & 7.32 \\
\hline $35 X-5,138-148$ & 321.56 & 257.00 & 50.53 & 7.30 & 1.95 & 493.38 & 110.25 & 7.28 \\
\hline 36X-3, 141-151 & 328.44 & 216.90 & 55.30 & 1.53 & 2.17 & 209.45 & 109.77 & 5.99 \\
\hline $37 X-6,135-150$ & 341.42 & 223.09 & 56.93 & 1.70 & 2.26 & 235.96 & 112.23 & 5.79 \\
\hline $38 X-5,135-150$ & 350.76 & 224.24 & 52.67 & 3.07 & 2.02 & 384.06 & 115.94 & 5.83 \\
\hline
\end{tabular}


Table T16 (continued). (Continued on next page.)

\begin{tabular}{|c|c|c|c|c|c|c|c|c|c|c|}
\hline $\begin{array}{l}\text { Core, section, } \\
\text { interval }(\mathrm{cm})\end{array}$ & $\begin{array}{l}\text { Depth } \\
\text { (mbsf) }\end{array}$ & $\begin{array}{l}\mathrm{pH} \\
\mathrm{ISE}\end{array}$ & $\begin{array}{c}\mathrm{Cl}^{-}(\mathrm{mM}) \\
\text { TITRA_AUTO }\end{array}$ & $\mathrm{SO}_{4}^{2-}(\mathrm{mM})$ & $\begin{array}{c}\mathrm{Na}^{+}(\mathrm{mM}) \\
\text { IC }\end{array}$ & $\begin{array}{c}\mathrm{K}^{+}(\mathrm{mM}) \\
\mathrm{IC}\end{array}$ & $\begin{array}{c}\mathrm{Mg}^{2+}(\mathrm{mN} \\
\text { IC }\end{array}$ & $\mathrm{a}^{2+}(\mathrm{mM})$ & $\mathrm{Na}^{+} / \mathrm{Cl}^{-}$ & $\begin{array}{c}\mathrm{NH}_{4}^{+}(\mu \mathrm{M}) \\
\quad \text { SPEC }\end{array}$ \\
\hline \multicolumn{11}{|l|}{ 339-U1391A- } \\
\hline $1 \mathrm{H}-2,145-150$ & 2.95 & 7.87 & 580.05 & 21.84 & 478.19 & 11.92 & 52.24 & 8.57 & 0.82 & 441.10 \\
\hline $2 \mathrm{H}-6,135-140$ & 12.95 & 7.75 & 574.92 & 3.80 & 468.37 & 10.44 & 43.72 & 4.04 & 0.81 & $2,169.40$ \\
\hline $3 \mathrm{H}-6,126-131$ & 22.36 & 7.96 & 573.72 & 0.00 & 469.79 & 9.50 & 37.08 & 2.90 & 0.82 & $2,297.90$ \\
\hline $4 \mathrm{H}-6,145-150$ & 32.05 & 7.93 & 571.85 & 0.00 & 456.96 & 8.61 & 33.18 & 3.70 & 0.80 & $2,705.00$ \\
\hline $5 \mathrm{H}-6,145-150$ & 41.55 & 7.98 & NA & 0.00 & 478.28 & 8.55 & 33.89 & 4.22 & NA & $2,865.80$ \\
\hline $6 \mathrm{H}-6,145-150$ & 51.10 & 7.92 & 569.16 & 0.00 & 460.17 & 8.57 & 31.90 & 4.49 & 0.81 & $3,050.40$ \\
\hline 7H-5, 145-150 & 59.23 & 7.91 & 568.12 & 0.00 & 461.83 & 8.22 & 31.26 & 4.92 & 0.81 & $3,453.40$ \\
\hline $8 \mathrm{H}-6,131-141$ & 69.79 & 7.92 & 566.28 & 0.00 & 460.38 & 8.09 & 30.21 & 4.95 & 0.81 & $4,003.00$ \\
\hline $9 \mathrm{H}-6,136-141$ & 79.31 & 7.99 & 562.35 & 0.00 & 498.79 & 8.76 & 32.04 & 5.34 & 0.89 & $4,115.40$ \\
\hline $10 \mathrm{H}-6,136-141$ & 88.60 & 7.87 & 566.94 & 0.00 & 470.51 & 8.04 & 30.22 & 5.48 & 0.83 & $4,032.50$ \\
\hline $11 \mathrm{H}-6,135-140$ & 97.84 & 7.98 & 560.24 & 0.00 & 480.93 & 8.44 & 30.70 & 5.14 & 0.86 & $4,401.80$ \\
\hline $12 \mathrm{H}-7,136-141$ & 107.89 & 7.98 & 563.26 & 0.00 & 495.63 & 8.96 & 31.93 & 5.08 & 0.88 & $4,565.30$ \\
\hline $13 \mathrm{H}-7,105-110$ & 117.72 & 8.02 & 566.25 & 0.00 & 484.43 & 9.12 & 31.38 & 4.91 & 0.86 & $5,160.60$ \\
\hline $14 \mathrm{H}-6,146-151$ & 126.66 & 7.97 & 560.34 & 0.00 & 487.67 & 9.17 & 31.53 & 4.61 & 0.87 & $5,165.60$ \\
\hline $15 \mathrm{H}-6,126-131$ & 135.99 & 8.00 & 560.29 & 0.00 & 488.32 & 8.61 & 31.80 & 4.69 & 0.87 & $4,945.10$ \\
\hline $16 \mathrm{H}-7,147-152$ & 146.23 & 8.12 & 560.03 & 0.00 & 489.82 & 8.62 & 30.94 & 4.44 & 0.87 & $5,171.90$ \\
\hline $17 \mathrm{H}-6,137-142$ & 155.11 & 8.05 & 561.90 & 0.00 & 472.15 & 8.23 & 29.56 & 4.76 & 0.84 & $5,660.50$ \\
\hline $18 \mathrm{H}-7,132-142$ & 165.33 & 7.94 & 559.09 & 0.00 & 461.74 & 7.89 & 28.56 & 4.62 & 0.83 & $5,811.40$ \\
\hline $20 X-4,140-150$ & 177.00 & NA & 560.13 & 0.00 & 471.04 & 7.79 & 28.38 & 4.95 & 0.84 & $6,063.40$ \\
\hline $21 X-4,133-143$ & 186.53 & NA & 558.37 & 0.00 & 499.58 & 8.38 & 29.19 & 5.19 & 0.89 & $6,655.90$ \\
\hline $22 X-3,140-150$ & 193.65 & NA & 553.75 & 0.00 & 487.40 & 7.65 & 29.38 & 6.18 & 0.88 & $5,887.20$ \\
\hline $23 X-3,140-150$ & 204.20 & NA & 557.63 & 0.00 & 477.03 & 7.47 & 27.09 & 5.41 & 0.86 & $7,067.30$ \\
\hline $25 X-3,140-150$ & 223.40 & 8.12 & 557.02 & 0.00 & 477.81 & 7.11 & 27.58 & 5.83 & 0.86 & $6,717.00$ \\
\hline $26 X-5,140-150$ & 234.80 & 7.82 & 557.37 & 0.00 & 469.32 & 6.87 & 26.19 & 5.57 & 0.84 & $7,574.10$ \\
\hline $27 X-2,140-150$ & 241.10 & 7.80 & 557.37 & 0.00 & 497.76 & 7.06 & 27.90 & 7.17 & 0.89 & $7,388.10$ \\
\hline $28 X-3,140-150$ & 252.21 & 7.65 & 558.53 & 0.00 & 484.53 & 6.78 & 27.93 & 7.17 & 0.87 & $7,918.80$ \\
\hline $29 X-3,134-144$ & 261.75 & 7.83 & 557.15 & 0.00 & 468.31 & 6.68 & 27.06 & 7.28 & 0.84 & $7,449.90$ \\
\hline $30 \times-3,140-150$ & 270.92 & 7.75 & 555.83 & 0.00 & 474.25 & 6.48 & 26.67 & 7.64 & 0.85 & $7,369.10$ \\
\hline $31 X-2,141-151$ & 279.51 & 7.73 & 557.81 & 0.00 & 500.26 & 7.27 & 27.43 & 7.35 & 0.90 & $7,528.50$ \\
\hline $32 X-3,140-150$ & 290.09 & 7.93 & 554.64 & 0.00 & 478.47 & 7.01 & 25.62 & 6.76 & 0.86 & $7,859.14$ \\
\hline $33 \times-2,140-150$ & 298.70 & 7.92 & 553.98 & 0.00 & 469.13 & 6.52 & 25.59 & 7.23 & 0.85 & $7,209.79$ \\
\hline $34 X-3,140-150$ & 309.50 & 7.94 & 557.43 & 0.00 & 479.16 & 6.25 & 26.06 & 7.34 & 0.86 & $6,806.14$ \\
\hline $35 X-5,138-148$ & 321.56 & 7.79 & 556.13 & 0.00 & 467.50 & 6.13 & 24.90 & 7.22 & 0.84 & $6,834.92$ \\
\hline $36 X-3,141-151$ & 328.44 & 8.06 & 551.81 & 0.00 & 494.67 & 6.53 & 26.28 & 7.23 & 0.90 & $6,445.31$ \\
\hline $37 X-6,135-150$ & 341.42 & 8.04 & 553.84 & 0.00 & 464.46 & 6.11 & 24.19 & 6.78 & 0.84 & $6,844.05$ \\
\hline $38 X-5,135-150$ & 350.76 & 7.91 & 552.87 & 0.00 & 497.61 & 6.53 & 26.97 & 7.82 & 0.90 & $6,713.47$ \\
\hline
\end{tabular}


Table T16 (continued). (Continued on next page.)

\begin{tabular}{|c|c|c|c|c|c|c|c|c|}
\hline $\begin{array}{l}\text { Core, section, } \\
\text { interval }(\mathrm{cm})\end{array}$ & $\begin{array}{l}\text { Depth } \\
\text { (mbsf) }\end{array}$ & $\begin{array}{c}\text { B }(\mu \mathrm{M}) \\
249.772 \mathrm{~nm} \\
\text { ICPAES }\end{array}$ & $\begin{array}{c}\text { Ba }(\mu \mathrm{M}) \\
455.40 \mathrm{~nm} \\
\text { ICPAES }\end{array}$ & $\begin{array}{c}\text { Fe }(\mu \mathrm{M}) \\
239.56 \mathrm{~nm} \\
\text { ICPAES }\end{array}$ & $\begin{array}{c}\mathrm{Li}(\mu \mathrm{M}) \\
670.78 \mathrm{~nm} \\
\text { ICPAES }\end{array}$ & $\begin{array}{c}\text { Si }(\mu \mathrm{M}) \\
288.16 \mathrm{~nm} \\
\text { ICPAES }\end{array}$ & $\begin{array}{c}\mathrm{Sr}(\mu \mathrm{M}) \\
407.77 \mathrm{~nm} \\
\text { ICPAES }\end{array}$ & $\begin{array}{c}\text { Alkalinity } \\
\text { (meq/L) } \\
\text { TITRA_AUTO }\end{array}$ \\
\hline \multicolumn{9}{|l|}{ 339-U1391C- } \\
\hline $3 R-3,140-150$ & 349.90 & 244.82 & 60.08 & 0.83 & 1.25 & 488.53 & 109.04 & 5.93 \\
\hline $4 \mathrm{R}-1,140-150$ & 356.50 & 236.29 & 59.29 & 0.39 & 1.41 & 314.96 & 116.02 & 6.49 \\
\hline $5 R-3,140-150$ & 369.10 & 216.83 & 58.19 & 0.81 & 1.10 & 467.94 & 111.99 & 5.94 \\
\hline $6 \mathrm{R}-1,140-150$ & 375.70 & 241.72 & 57.64 & 0.90 & 1.14 & 332.90 & 113.74 & 6.26 \\
\hline $7 R-3,140-150$ & 388.30 & 208.63 & 59.92 & 1.75 & 1.16 & 355.54 & 110.49 & 6.12 \\
\hline $8 R-2,140-150$ & 396.40 & 214.21 & 62.33 & -0.05 & 1.41 & 274.24 & 111.43 & 6.42 \\
\hline $9 R-4,140-150$ & 407.50 & 270.24 & 53.47 & 3.29 & 0.93 & 362.85 & 120.43 & 7.24 \\
\hline $10 R-4,140-150$ & 418.50 & 255.13 & 63.26 & 1.69 & 1.34 & 605.34 & 113.35 & 8.68 \\
\hline 11R-5, 141-151 & 429.61 & 213.44 & 64.38 & 1.79 & 1.51 & 342.48 & 112.87 & 8.73 \\
\hline $12 \mathrm{R}-6,141-151$ & 440.71 & 227.85 & 66.30 & 0.27 & 1.43 & 373.78 & 110.39 & 9.08 \\
\hline $13 R-5,140-150$ & 448.70 & 219.22 & 64.21 & 0.94 & 1.57 & 351.82 & 114.13 & 9.43 \\
\hline 14R-6, 136-151 & 459.76 & 239.40 & 63.05 & 1.64 & 1.02 & 521.67 & 106.69 & 12.48 \\
\hline 15R-6, 135-150 & 468.60 & 253.54 & 62.28 & 3.87 & 0.98 & 542.62 & 111.82 & 14.42 \\
\hline 16R-5, 135-150 & 477.35 & 226.19 & 59.51 & 1.08 & 1.09 & 416.41 & 113.22 & 14.99 \\
\hline $17 R-2,135-150$ & 482.55 & 233.48 & 56.16 & 0.74 & 0.55 & 376.28 & 107.67 & 14.53 \\
\hline $18 R-4,135-150$ & 494.85 & 283.70 & 61.01 & 1.29 & 1.14 & 409.57 & 123.32 & 19.61 \\
\hline $19 R-4,135-150$ & 504.45 & 211.44 & 61.72 & 0.65 & 0.60 & 445.71 & 111.06 & 19.85 \\
\hline 20R-1, 135-150 & 509.45 & 225.68 & 63.24 & 0.97 & 0.99 & 460.28 & 120.24 & 22.12 \\
\hline $21 \mathrm{R}-4,135-150$ & 523.55 & 232.77 & 71.27 & 1.15 & 0.91 & 774.30 & 127.36 & 27.89 \\
\hline $22 R-4,135-150$ & 533.15 & 253.01 & 69.83 & 1.36 & 0.94 & 572.59 & 130.85 & 27.90 \\
\hline $23 R-4,135-150$ & 542.87 & 214.59 & 63.87 & 1.92 & 0.15 & 386.84 & 122.72 & 25.91 \\
\hline $24 R-4,135-150$ & 552.45 & 185.33 & 56.79 & 1.07 & -0.09 & 351.89 & 110.93 & 25.06 \\
\hline $25 R-5,135-150$ & 563.55 & 284.36 & 89.37 & 7.40 & 1.59 & 677.61 & 145.95 & 36.31 \\
\hline $27 R-5,135-150$ & 582.73 & 279.07 & 76.84 & 3.39 & 0.54 & 859.34 & 162.12 & 37.03 \\
\hline $28 R-5,135-150$ & 592.35 & 280.54 & 103.48 & 18.89 & 1.95 & 884.28 & 166.13 & 39.51 \\
\hline $30 R-5,135-150$ & 611.55 & 260.47 & 99.31 & 1.01 & 0.95 & 869.56 & 162.76 & NA \\
\hline $31 R-4,135-150$ & 619.65 & 262.06 & 101.68 & 2.64 & 1.08 & 1020.62 & 178.06 & 39.02 \\
\hline $32 R-4,135-150$ & 629.24 & 265.32 & 107.66 & 4.35 & 1.32 & 921.49 & 175.36 & 36.56 \\
\hline $33 R-5,138-150$ & 640.39 & 258.04 & 107.14 & 4.13 & 1.27 & 787.01 & 179.17 & 36.41 \\
\hline $34 \mathrm{R}-4,135-150$ & 648.45 & 285.03 & 100.02 & 3.18 & 0.49 & 892.52 & 179.55 & 35.50 \\
\hline $36 \mathrm{R}-3,135-150$ & 666.15 & 257.58 & 97.66 & 3.46 & 0.28 & 911.64 & 183.63 & 37.01 \\
\hline
\end{tabular}

TITRA_AUTO = automatic titration, SPEC = spectrometer, IC = ion chromatograph, ICPAES = inductively coupled plasma-atomic emission spectrometer, ISE = ion-selective electrode. $\mathrm{NA}=$ not available. 
Table T16 (continued).

\begin{tabular}{|c|c|c|c|c|c|c|c|c|c|c|}
\hline $\begin{array}{l}\text { Core, section, } \\
\text { interval }(\mathrm{cm})\end{array}$ & $\begin{array}{l}\text { Depth } \\
\text { (mbsf) }\end{array}$ & $\begin{array}{l}\mathrm{pH} \\
\text { ISE }\end{array}$ & $\begin{array}{c}\mathrm{Cl}^{-}(\mathrm{mM}) \\
\text { TITRA_AUTO }\end{array}$ & $\begin{array}{c}\mathrm{SO}_{4}{ }^{2-}(\mathrm{mM}) \\
\mathrm{IC}\end{array}$ & $\begin{array}{c}\mathrm{Na}(\mathrm{mM}) \\
\mathrm{IC}\end{array}$ & $\underset{I C}{K(m M)}$ & $\underset{\text { IC }}{\operatorname{Mg}(\mathrm{mM})}$ & $\begin{array}{c}\mathrm{Ca}(\mathrm{mM}) \\
\text { IC }\end{array}$ & $\mathrm{Na} / \mathrm{Cl}$ & $\begin{array}{l}\mathrm{NH}_{4}^{+}(\mu \mathrm{M}) \\
\text { SPEC }\end{array}$ \\
\hline \multicolumn{11}{|l|}{ 339-U1391C- } \\
\hline $3 R-3,140-150$ & 349.90 & 7.97 & 556.72 & 0.00 & 517.35 & 5.94 & 25.37 & 7.39 & 0.93 & $3,667.20$ \\
\hline $4 R-1,140-150$ & 356.50 & 7.93 & 553.95 & 0.00 & 493.40 & 5.80 & 24.53 & 7.49 & 0.89 & $6,648.26$ \\
\hline $5 R-3,140-150$ & 369.10 & 7.93 & 557.18 & 0.00 & 493.28 & 5.86 & 25.17 & 7.45 & 0.89 & $5,747.74$ \\
\hline $6 R-1,140-150$ & 375.70 & 7.68 & 555.75 & 0.00 & 496.39 & 5.88 & 25.50 & 7.52 & 0.89 & $6,233.80$ \\
\hline $7 R-3,140-150$ & 388.30 & 8.01 & 553.34 & 0.00 & 478.49 & 6.06 & 23.56 & 6.68 & 0.86 & $5,700.24$ \\
\hline $8 R-2,140-150$ & 396.40 & 8.04 & 550.70 & 0.00 & 498.47 & 6.51 & 24.29 & 6.86 & 0.91 & $6,340.51$ \\
\hline $9 R-4,140-150$ & 407.50 & 7.86 & 555.70 & 0.62 & 510.55 & 6.58 & 26.91 & 7.02 & 0.92 & $5,466.85$ \\
\hline $10 R-4,140-150$ & 418.50 & 7.87 & 551.44 & 0.00 & 482.93 & 6.11 & 24.09 & 6.54 & 0.88 & $5,772.53$ \\
\hline 11R-5, 141-151 & 429.61 & 8.04 & 552.66 & 0.00 & 494.23 & 6.83 & 25.24 & 6.33 & 0.89 & $6,003.17$ \\
\hline 12R-6, 141-151 & 440.71 & 7.96 & 552.04 & 0.00 & 480.09 & 6.51 & 24.04 & 5.65 & 0.87 & $6,327.43$ \\
\hline $13 R-5,140-150$ & 448.70 & 8.03 & 550.90 & 0.00 & 482.31 & 6.53 & 23.86 & 4.75 & 0.88 & $6,653.77$ \\
\hline 14R-6, 136-151 & 459.76 & 7.85 & 551.14 & 0.00 & 471.06 & 6.22 & 23.93 & 5.12 & 0.85 & $6,713.66$ \\
\hline $15 R-6,135-150$ & 468.60 & 7.73 & 549.85 & 0.00 & 483.43 & 6.72 & 25.93 & 5.11 & 0.88 & $6,925.02$ \\
\hline $16 R-5,135-150$ & 477.35 & 7.94 & 550.16 & 0.00 & 486.54 & 7.57 & 27.16 & 3.96 & 0.88 & $6,772.87$ \\
\hline $17 R-2,135-150$ & 482.55 & 7.67 & 551.38 & 0.04 & 493.76 & 7.95 & 28.73 & 3.83 & 0.90 & $6,606.95$ \\
\hline $18 R-4,135-150$ & 494.85 & 7.83 & 553.33 & 0.00 & 510.53 & 8.38 & 29.90 & 3.60 & 0.92 & $8,001.10$ \\
\hline $19 R-4,135-150$ & 504.45 & 7.87 & 547.40 & 0.00 & 494.94 & 8.70 & 29.23 & 3.01 & 0.90 & $7,805.57$ \\
\hline $20 \mathrm{R}-1,135-150$ & 509.45 & 7.61 & 552.79 & 0.00 & 486.96 & 8.64 & 30.26 & 3.38 & 0.88 & $7,636.90$ \\
\hline $21 R-4,135-150$ & 523.55 & 8.02 & 548.47 & 0.00 & 484.39 & 8.61 & 30.74 & 4.02 & 0.88 & $8,164.95$ \\
\hline $22 \mathrm{R}-4,135-150$ & 533.15 & 8.05 & 547.14 & 0.00 & 485.14 & 9.05 & 32.11 & 3.91 & 0.89 & $8,445.84$ \\
\hline $23 R-4,135-150$ & 542.87 & 7.57 & 552.71 & 0.00 & 523.11 & 10.73 & 35.85 & 3.68 & 0.95 & $8,754.28$ \\
\hline $24 R-4,135-150$ & 552.45 & 7.69 & 551.30 & 0.00 & 489.10 & 10.94 & 32.93 & 2.66 & 0.89 & $9,488.18$ \\
\hline $25 R-5,135-150$ & 563.55 & 7.71 & 547.46 & 0.00 & 471.05 & 9.59 & 32.64 & 4.34 & 0.86 & $9,247.91$ \\
\hline $27 R-5,135-150$ & 582.73 & 7.46 & 549.76 & 0.00 & 481.61 & 10.07 & 35.51 & 5.59 & 0.88 & $8,909.18$ \\
\hline $28 \mathrm{R}-5,135-150$ & 592.35 & 7.33 & 544.34 & 0.00 & 487.81 & 10.03 & 33.84 & 5.94 & 0.90 & $10,082.33$ \\
\hline $30 R-5,135-150$ & 611.55 & NA & 547.49 & 0.00 & 506.80 & 11.26 & 34.68 & 5.64 & 0.93 & $10,190.42$ \\
\hline $31 R-4,135-150$ & 619.65 & 7.53 & 549.82 & 0.00 & 501.71 & 10.89 & 34.87 & 7.05 & 0.91 & $10,268.90$ \\
\hline $32 R-4,135-150$ & 629.24 & 7.21 & 545.77 & 0.00 & 500.64 & 10.08 & 32.85 & 6.41 & 0.92 & $10,549.80$ \\
\hline $33 R-5,138-150$ & 640.39 & 7.28 & 546.38 & 0.00 & 483.38 & 10.40 & 31.81 & 6.32 & 0.88 & $11,060.64$ \\
\hline $34 R-4,135-150$ & 648.45 & 7.29 & 545.65 & 0.00 & 469.74 & 10.34 & 31.54 & 5.88 & 0.86 & $11,152.90$ \\
\hline $36 R-3,135-150$ & 666.15 & 7.36 & 549.89 & 0.00 & 475.35 & 10.44 & 33.50 & 5.92 & 0.86 & $10,223.47$ \\
\hline
\end{tabular}


Table T17. Interstitial water oxygen and hydrogen isotopes, Site U1391.

\begin{tabular}{|c|c|c|c|}
\hline $\begin{array}{l}\text { Core, section, } \\
\text { interval }(\mathrm{cm})\end{array}$ & $\begin{array}{l}\text { Depth } \\
\text { (mbsf) }\end{array}$ & $\begin{array}{c}\delta^{18} \mathrm{O} \\
(\% \circ, \text { VSMOW) }\end{array}$ & $\begin{array}{c}\delta \mathrm{D} \\
(\% \circ, \mathrm{VSMOW})\end{array}$ \\
\hline \multicolumn{4}{|l|}{ 339-U1391A- } \\
\hline $1 \mathrm{H}-2,145-150$ & 3.00 & 0.94 & 3.82 \\
\hline $2 \mathrm{H}-6,135-140$ & 13.00 & 0.87 & 5.46 \\
\hline $3 \mathrm{H}-6,126-131$ & 22.41 & 1.03 & 7.30 \\
\hline $4 \mathrm{H}-6,145-150$ & 32.10 & 0.87 & 7.25 \\
\hline $5 \mathrm{H}-6,145-150$ & 41.60 & 0.95 & 8.71 \\
\hline $6 \mathrm{H}-6,145-150$ & 51.15 & 1.07 & 6.71 \\
\hline $7 \mathrm{H}-5,145-150$ & 59.30 & 0.37 & 1.75 \\
\hline 7H-5, 145-150 & 59.30 & 0.32 & 1.32 \\
\hline $8 \mathrm{H}-6,131-136$ & 69.91 & 0.68 & 6.36 \\
\hline $9 \mathrm{H}-6,136-141$ & 79.36 & 0.88 & 6.50 \\
\hline $10 \mathrm{H}-6,136-141$ & 88.65 & 1.44 & 6.64 \\
\hline $11 \mathrm{H}-6,135-140$ & 97.89 & 1.21 & 6.68 \\
\hline $12 \mathrm{H}-7,136-141$ & 107.94 & 0.91 & 5.77 \\
\hline $14 \mathrm{H}-6,146-151$ & 126.7 & 0.76 & 6.11 \\
\hline $15 \mathrm{H}-6,126-131$ & 136.05 & 0.78 & 6.29 \\
\hline $16 \mathrm{H}-7,147-152$ & 146.28 & 0.71 & 5.05 \\
\hline $17 \mathrm{H}-6,137-142$ & 155.16 & 0.74 & 5.07 \\
\hline $18 \mathrm{H}-7,132-137$ & 165.43 & 0.70 & 5.59 \\
\hline $20 X-4,140-145$ & 177.1 & 0.84 & 3.45 \\
\hline $21 X-4,133-138$ & 186.63 & 0.91 & 5.56 \\
\hline $22 X-3,140-145$ & 193.75 & 0.41 & 4.65 \\
\hline
\end{tabular}

VSMOW = Vienna standard mean ocean water.

Table T18. Results from APCT-3 temperature profiles, Site U1391.

\begin{tabular}{lccccc}
\hline Core & $\begin{array}{c}\text { Original } \\
\text { depth } \\
(\mathrm{mbsf})\end{array}$ & $\begin{array}{c}\text { Tidal sea } \\
\text { level height* } \\
(\mathrm{m})\end{array}$ & $\begin{array}{c}\text { Corrected } \\
\text { depth } \\
(\mathrm{mbsf})\end{array}$ & $\begin{array}{c}\text { In situ } \\
\text { temperature } \\
\left({ }^{\circ} \mathrm{C}\right)\end{array}$ & $\begin{array}{c}\text { Thermal } \\
\text { resistance } \\
\left(\mathrm{m}^{2} \mathrm{~K} / \mathrm{W}\right)\end{array}$ \\
\hline 339-U1391A- & & & & & \\
4H & 32.0 & -0.4 & 32.6 & 11.8 & 25.7 \\
7H & 59.5 & 0.7 & 61.1 & $\dagger$ & \\
10H & 87.4 & 1.3 & 89.6 & 12.6 & 71.4 \\
13H & 116.3 & 0.8 & 118.1 & 13.1 & 95.9 \\
16H & 146.0 & -0.4 & 146.6 & 13.3 & 117.6 \\
339-U1391B- & & & & & \\
2H & 19.3 & -1.3 & 19.0 & $\dagger$ & \\
5H & 47.2 & -0.7 & 47.5 & 12.0 & 37.2 \\
8H & 74.4 & 0.6 & 76.0 & 12.5 & 60.7 \\
11H & 102.3 & 1.2 & 104.5 & 12.8 & 85.2 \\
14H & 131.4 & 0.6 & 133.0 & 13.2 & 106.1 \\
\hline
\end{tabular}

${ }^{*}=-1.0 \mathrm{~m}$ tidal height when mudline Core $339-\mathrm{U} 1391 \mathrm{~A}-1 \mathrm{H}$ was taken. $\dagger=$ large range of possible values from the temperature decay curve. 
Table T19. Meters composite depth scale, Site U1391.

\begin{tabular}{|c|c|c|c|}
\hline \multirow[b]{2}{*}{ Core } & \multicolumn{2}{|c|}{ Top depth } & \multirow[b]{2}{*}{ Offset (m) } \\
\hline & (mbsf) & $(\mathrm{mcd})$ & \\
\hline \multicolumn{4}{|c|}{ 339-U1391A- } \\
\hline $1 \mathrm{H}$ & 0.00 & 0.00 & 0.00 \\
\hline $2 \mathrm{H}$ & 4.10 & 5.05 & 0.95 \\
\hline $3 \mathrm{H}$ & 13.60 & 15.64 & 2.04 \\
\hline $4 \mathrm{H}$ & 23.10 & 25.68 & 2.58 \\
\hline $5 \mathrm{H}$ & 32.60 & 35.63 & 3.03 \\
\hline $6 \mathrm{H}$ & 42.10 & 45.01 & 2.91 \\
\hline $7 \mathrm{H}$ & 51.60 & 55.36 & 3.76 \\
\hline $8 \mathrm{H}$ & 61.10 & 65.78 & 4.68 \\
\hline $9 \mathrm{H}$ & 70.60 & 75.56 & 4.96 \\
\hline $10 \mathrm{H}$ & 80.10 & 86.75 & 6.65 \\
\hline $11 \mathrm{H}$ & 89.60 & 97.41 & 7.81 \\
\hline $12 \mathrm{H}$ & 99.10 & 107.82 & 8.72 \\
\hline $13 \mathrm{H}$ & 108.60 & 118.35 & 9.75 \\
\hline $14 \mathrm{H}$ & 118.10 & 129.71 & 11.61 \\
\hline $15 \mathrm{H}$ & 127.60 & 143.14 & 15.54 \\
\hline $16 \mathrm{H}$ & 137.10 & 157.34 & 20.24 \\
\hline $17 \mathrm{H}$ & 146.60 & 170.33 & 23.73 \\
\hline $18 \mathrm{H}$ & 156.10 & 180.83 & 24.73 \\
\hline $19 \mathrm{H}$ & 165.60 & 191.33 & 25.73 \\
\hline $20 x$ & 171.10 & 196.83 & 25.73 \\
\hline $21 X$ & 180.70 & 206.68 & 25.98 \\
\hline $22 x$ & 190.20 & 216.17 & 25.97 \\
\hline $23 x$ & 199.80 & 229.56 & 29.76 \\
\hline $24 X$ & 209.40 & 239.16 & 29.76 \\
\hline $25 X$ & 219.00 & 249.75 & 30.75 \\
\hline $26 \mathrm{X}$ & 228.60 & 260.35 & 31.75 \\
\hline $27 x$ & 238.20 & 272.15 & 33.95 \\
\hline $28 x$ & 247.80 & 282.75 & 34.95 \\
\hline $29 x$ & 257.40 & 292.35 & 34.95 \\
\hline $30 \mathrm{X}$ & 267.00 & 306.26 & 39.26 \\
\hline $31 x$ & 276.60 & 315.87 & 39.27 \\
\hline $32 x$ & 286.20 & 325.48 & 39.28 \\
\hline $33 x$ & 295.80 & 336.82 & 41.02 \\
\hline $34 X$ & 305.10 & 348.11 & 43.01 \\
\hline $35 x$ & 314.70 & 359.71 & 45.01 \\
\hline $36 \mathrm{X}$ & 324.30 & 373.50 & 49.20 \\
\hline $37 X$ & 333.90 & 387.10 & 53.20 \\
\hline $38 \mathrm{X}$ & 343.50 & 398.69 & 55.19 \\
\hline \multicolumn{4}{|c|}{ 339-U1391B- } \\
\hline $1 \mathrm{H}$ & 0.00 & 0.79 & 0.79 \\
\hline $2 \mathrm{H}$ & 9.50 & 11.81 & 2.31 \\
\hline $3 \mathrm{H}$ & 19.00 & 21.30 & 2.30 \\
\hline $4 \mathrm{H}$ & 28.50 & 31.49 & 2.99 \\
\hline $5 \mathrm{H}$ & 38.00 & 41.52 & 3.52 \\
\hline $6 \mathrm{H}$ & 47.50 & 50.09 & 2.59 \\
\hline $7 \mathrm{H}$ & 57.00 & 60.69 & 3.69 \\
\hline $8 \mathrm{H}$ & 66.50 & 71.39 & 4.89 \\
\hline $9 \mathrm{H}$ & 76.00 & 80.99 & 4.99 \\
\hline $10 \mathrm{H}$ & 85.50 & 91.95 & 6.45 \\
\hline $11 \mathrm{H}$ & 95.00 & 102.65 & 7.65 \\
\hline $12 \mathrm{H}$ & 104.50 & 113.59 & 9.09 \\
\hline $13 \mathrm{H}$ & 114.00 & 123.47 & 9.47 \\
\hline $14 \mathrm{H}$ & 123.50 & 135.97 & 12.47 \\
\hline $15 \mathrm{H}$ & 133.00 & 149.26 & 16.26 \\
\hline $16 \mathrm{H}$ & 142.50 & 164.51 & 22.01 \\
\hline $17 \mathrm{H}$ & 152.00 & 175.81 & 23.81 \\
\hline
\end{tabular}

\begin{tabular}{|c|c|c|c|}
\hline \multirow[b]{2}{*}{ Core } & \multicolumn{2}{|c|}{ Top depth } & \multirow[b]{2}{*}{ Offset (m) } \\
\hline & (mbsf) & $(\mathrm{mcd})$ & \\
\hline $18 \mathrm{H}$ & 161.50 & 186.92 & 25.42 \\
\hline $19 X$ & 171.00 & 197.02 & 26.02 \\
\hline $20 x$ & 175.50 & 201.53 & 26.03 \\
\hline $21 x$ & 185.10 & 212.72 & 27.62 \\
\hline $22 X$ & 194.60 & 223.52 & 28.92 \\
\hline $23 x$ & 204.20 & 233.62 & 29.42 \\
\hline $24 X$ & 213.80 & 243.22 & 29.42 \\
\hline $25 X$ & 223.40 & 252.82 & 29.42 \\
\hline $26 \mathrm{X}$ & 233.00 & 265.22 & 32.22 \\
\hline $27 X$ & 242.60 & 275.82 & 33.22 \\
\hline $28 \mathrm{X}$ & 252.20 & 285.43 & 33.23 \\
\hline $29 x$ & 261.80 & 298.04 & 36.24 \\
\hline $30 x$ & 271.40 & 310.24 & 38.84 \\
\hline $31 x$ & 281.00 & 319.84 & 38.84 \\
\hline $32 x$ & 290.60 & 329.43 & 38.83 \\
\hline $33 x$ & 300.20 & 342.78 & 42.58 \\
\hline $34 X$ & 309.80 & 354.47 & 44.67 \\
\hline $35 x$ & 319.00 & 367.27 & 48.27 \\
\hline $36 \mathrm{X}$ & 328.70 & 382.37 & 53.67 \\
\hline $37 X$ & 338.20 & 395.07 & 56.87 \\
\hline $38 \mathrm{X}$ & 347.90 & 409.16 & 61.26 \\
\hline \multicolumn{4}{|c|}{ 339-U1391C- } \\
\hline $1 \mathrm{~W}$ & 0.00 & 0.79 & 0.79 \\
\hline $2 \mathrm{R}$ & 340.00 & 396.34 & 56.34 \\
\hline $3 \mathrm{R}$ & 345.50 & 403.90 & 58.40 \\
\hline $4 \mathrm{R}$ & 355.10 & 414.85 & 59.75 \\
\hline $5 \mathrm{R}$ & 364.70 & 425.79 & 61.09 \\
\hline $6 \mathrm{R}$ & 374.30 & 436.73 & 62.43 \\
\hline $7 \mathrm{R}$ & 383.90 & 447.68 & 63.78 \\
\hline $8 \mathrm{R}$ & 393.50 & 458.62 & 65.12 \\
\hline $9 \mathrm{R}$ & 403.00 & 469.45 & 66.45 \\
\hline $10 R$ & 412.60 & 480.39 & 67.79 \\
\hline $11 R$ & 422.20 & 491.34 & 69.14 \\
\hline $12 \mathrm{R}$ & 431.80 & 502.28 & 70.48 \\
\hline $13 \mathrm{R}$ & 441.30 & 513.11 & 71.81 \\
\hline $14 \mathrm{R}$ & 450.90 & 524.06 & 73.16 \\
\hline $15 R$ & 460.50 & 535.00 & 74.50 \\
\hline $16 \mathrm{R}$ & 470.00 & 545.83 & 75.83 \\
\hline $17 \mathrm{R}$ & 479.70 & 556.89 & 77.19 \\
\hline $18 \mathrm{R}$ & 489.00 & 567.49 & 78.49 \\
\hline $19 \mathrm{R}$ & 498.60 & 578.43 & 79.83 \\
\hline $20 \mathrm{R}$ & 508.10 & 589.26 & 81.16 \\
\hline $21 R$ & 517.70 & 600.21 & 82.51 \\
\hline $22 \mathrm{R}$ & 527.30 & 611.15 & 83.85 \\
\hline $23 \mathrm{R}$ & 537.00 & 622.21 & 85.21 \\
\hline $24 \mathrm{R}$ & 546.60 & 633.15 & 86.55 \\
\hline $25 R$ & 556.20 & 644.10 & 87.90 \\
\hline $26 \mathrm{R}$ & 565.80 & 655.04 & 89.24 \\
\hline $27 \mathrm{R}$ & 575.40 & 665.99 & 90.59 \\
\hline $28 \mathrm{R}$ & 585.00 & 676.93 & 91.93 \\
\hline $29 \mathrm{R}$ & 594.60 & 687.87 & 93.27 \\
\hline $30 \mathrm{R}$ & 604.20 & 698.82 & 94.62 \\
\hline $31 \mathrm{R}$ & 613.80 & 709.76 & 95.96 \\
\hline $32 \mathrm{R}$ & 623.40 & 720.71 & 97.31 \\
\hline $33 R$ & 633.00 & 731.65 & 98.65 \\
\hline $34 R$ & 642.60 & 742.59 & 99.99 \\
\hline $35 \mathrm{R}$ & 652.20 & 753.54 & 101.34 \\
\hline $36 \mathrm{R}$ & 661.80 & 764.48 & 102.68 \\
\hline
\end{tabular}


Table T20. Splice tie points for Site U1391. (Continued on next page.)

\begin{tabular}{|c|c|c|c|c|c|c|}
\hline \multirow{2}{*}{$\begin{array}{l}\text { Hole, core, section, } \\
\text { interval }(\mathrm{cm})\end{array}$} & \multicolumn{2}{|c|}{ Depth } & & \multirow{2}{*}{$\begin{array}{l}\text { Hole, core, section, } \\
\text { interval }(\mathrm{cm})\end{array}$} & \multicolumn{2}{|c|}{ Depth } \\
\hline & (mbsf) & (mcd) & & & (mbsf) & (mcd) \\
\hline \multirow[t]{2}{*}{$339-$} & & & & $339-$ & & \\
\hline & & & & U1391A-1H-1, 0 & 0.00 & 0.00 \\
\hline U1391A-1H-2, 56.88 & 2.07 & 2.07 & Tie to & U1391B-1H-1, 127.5 & 1.28 & 2.07 \\
\hline U1391B-1H-4, 54.8 & 5.06 & 5.85 & Tie to & U1391A-2H-1, 79.73 & 4.90 & 5.85 \\
\hline U1391A-2H-6, 83.21 & 12.43 & 13.38 & Tie to & U1391B-2H-2, 6.73 & 11.07 & 13.38 \\
\hline U1391B-2H-5, 11.37 & 15.61 & 17.92 & Tie to & U1391A-3H-2, 77.82 & 15.88 & 17.92 \\
\hline U1391A-3H-7, 46.44 & 22.87 & 24.91 & Tie to & U1391B-3H-3, 61.44 & 22.61 & 24.91 \\
\hline U1391B-3H-6, 122.5 & 27.73 & 30.03 & Tie to & U1391A-4H-3, 135.46 & 27.45 & 30.03 \\
\hline U1391A-4H-5, 147.81 & 30.58 & 33.16 & Tie to & U1391B-4H-2, 16.77 & 30.17 & 33.16 \\
\hline U1391B-4H-7, 22.14 & 37.58 & 40.57 & Tie to & U1391A-5H-4, 43.77 & 37.54 & 40.57 \\
\hline U1391A-5H-6, 81.45 & 40.91 & 43.94 & Tie to & U1391B-5H-2, 91.7 & 40.42 & 43.94 \\
\hline U1391B-5H-3, 145.86 & 42.46 & 45.98 & Tie to & U1391A-6H-1, 97.37 & 43.07 & 45.98 \\
\hline U1391A-6H-6, 123.27 & 50.88 & 53.79 & Tie to & U1391B-6H-3, 70.4 & 51.20 & 53.79 \\
\hline U1391B-6H-6, 55.03 & 55.45 & 58.04 & Tie to & U1391A-7H-2, 115.58 & 54.28 & 58.04 \\
\hline U1391A-7H-6, 137.29 & 60.67 & 64.43 & Tie to & U1391B-7H-3, 81.94 & 60.74 & 64.43 \\
\hline U1391B-7H-5, 125.72 & 62.93 & 66.62 & Tie to & U1391A-8H-1, 84.39 & 61.94 & 66.62 \\
\hline U1391A-8H-6, 69.72 & 69.18 & 73.86 & Tie to & U1391B-8H-2, 104.65 & 68.97 & 73.86 \\
\hline U1391B-8H-4, 53.71 & 71.29 & 76.18 & Tie to & U1391A-9H-1, 61.73 & 71.22 & 76.18 \\
\hline U1391A-9H-7, 44.41 & 79.80 & 84.76 & Tie to & U1391B-9H-3, 93.68 & 79.77 & 84.76 \\
\hline U1391B-9H-6, 114.7 & 84.29 & 89.28 & Tie to & U1391A-10H-2, 111.19 & 82.63 & 89.28 \\
\hline U1391A-10H-6, 124.65 & 88.49 & 95.14 & Tie to & U1391B-10H-3, 55.47 & 88.69 & 95.14 \\
\hline U1391B-10H-6, 21.59 & 92.74 & 99.19 & Tie to & U1391A-11H-2, 36.95 & 91.38 & 99.19 \\
\hline U1391A-11H-5, 70.28 & 95.83 & 103.64 & Tie to & U1391B-11H-1, 98.9 & 95.99 & 103.64 \\
\hline U1391B-11H-5, 62.56 & 101.29 & 108.94 & Tie to & U1391A-12H-2, 52.84 & 100.22 & 108.94 \\
\hline U1391A-12H-6, 106 & 106.13 & 114.85 & Tie to & U1391B-12H-1, 125.52 & 105.76 & 114.85 \\
\hline U1391B-12H-5, 107.17 & 111.29 & 120.38 & Tie to & U1391A-13H-2, 88.56 & 110.63 & 120.38 \\
\hline U1391A-13H-7, 48 & 117.15 & 126.90 & Tie to & U1391B-13H-3, 61.3 & 117.43 & 126.90 \\
\hline U1391B-13H-6, 33.31 & 121.40 & 130.87 & Tie to & U1391A-14H-1, 115.62 & 119.26 & 130.87 \\
\hline U1391A-14H-5, 115.2 & 124.95 & 136.56 & Tie to & U1391B-14H-1, 58.98 & 124.09 & 136.56 \\
\hline U1391B-14H-6, 105.1 & 131.65 & 144.12 & Tie to & U1391A-15H-1, 97.5 & 128.58 & 144.12 \\
\hline U1391A-15H-6, 44.55 & 135.18 & 150.72 & Tie to & U1391B-15H-2, 103.39 & 134.46 & 150.72 \\
\hline U1391B-15H-7, 131.01 & 141.94 & 158.20 & Tie to & U1391A-16H-2, 42.5 & 137.96 & 158.20 \\
\hline U1391A-16H-7, 115.54 & 145.92 & 166.16 & Tie to & U1391B-16H-2, 22.73 & 144.15 & 166.16 \\
\hline U1391B-16H-5, 141.48 & 149.73 & 171.74 & Tie to & U1391A-17H-2, 0.59 & 148.01 & 171.74 \\
\hline U1391A-17H-5, 58.37 & 152.82 & 176.55 & Tie to & U1391B-17H-1, 73.7 & 152.74 & 176.55 \\
\hline U1391B-17H-5, 55.11 & 158.30 & 182.11 & Tie to & U1391A-18H-2, 24.68 & 157.38 & 182.11 \\
\hline U1391A-18H-6, 80.89 & 163.39 & 188.12 & Tie to & U1391B-18H-1, 119.67 & 162.70 & 188.12 \\
\hline U1391B-18H-4, 145.97 & 166.99 & 192.41 & Tie to & U1391A-19H-1, 107.5 & 166.68 & 192.41 \\
\hline U1391A-19H-4, 134.64 & 171.10 & 196.83 & Append to & U1391A-20X-1, 0 & 171.10 & 196.83 \\
\hline U1391A-20X-4, 115.51 & 176.76 & 202.49 & Tie to & U1391B-20X-2, 49.8 & 176.46 & 202.49 \\
\hline U1391B-20X-5, 21.39 & 180.67 & 206.70 & Tie to & U1391A-21X-1, 2.45 & 180.72 & 206.70 \\
\hline U1391A-21X-5, 95.53 & 187.59 & 213.57 & Tie to & U1391B-21X-1, 85.04 & 185.95 & 213.57 \\
\hline U1391B-21X-4, 88.66 & 190.25 & 217.87 & Tie to & U1391A-22X-2, 115.14 & 191.90 & 217.87 \\
\hline U1391A-22X-7, 62.82 & 198.01 & 223.98 & Tie to & U1391B-22X-1, 45.88 & 195.06 & 223.98 \\
\hline U1391B-22X-5, 96.13 & 201.56 & 230.48 & Tie to & U1391A-23X-1, 91.9 & 200.72 & 230.48 \\
\hline U1391A-23X-4, 29.65 & 204.60 & 234.36 & Tie to & U1391B-23X-1, 74.03 & 204.94 & 234.36 \\
\hline U1391B-23X-6, 144.66 & 213.17 & 242.59 & Append to & U1391B-24X-1, 0.07 & 213.80 & 243.22 \\
\hline U1391B-24X-5, 116.69 & 220.97 & 250.39 & Tie to & U1391A-25X-1, 63.65 & 219.64 & 250.39 \\
\hline U1391A-25X-3, 42.13 & 222.42 & 253.17 & Tie to & U1391B-25X-1, 35.23 & 223.75 & 253.17 \\
\hline U1391B-25X-5, 124.34 & 230.64 & 260.06 & Append to & U1391A-26X-1, 0 & 228.60 & 260.35 \\
\hline U1391A-26X-5, 78.31 & 234.18 & 265.93 & Tie to & U1391B-26X-1, 70.68 & 233.71 & 265.93 \\
\hline U1391B-26X-6, 83.96 & 240.02 & 272.24 & Append to & U1391A-27X-1, 1.64 & 238.22 & 272.17 \\
\hline U1391A-27X-5, 4.36 & 244.08 & 278.03 & Tie to & U1391B-27X-2, 72.58 & 244.81 & 278.03 \\
\hline U1391B-27X-5, 100.04 & 249.59 & 282.81 & Tie to & U1391A-28X-1, 5.64 & 247.86 & 282.81 \\
\hline U1391A-28X-4, 63.64 & 252.95 & 287.90 & Tie to & U1391B-28X-2, 96.67 & 254.67 & 287.90 \\
\hline U1391B-28X-5, 140.9 & 259.11 & 292.34 & Append to & U1391A-29X-1, 1.21 & 257.41 & 292.36 \\
\hline U1391A-29X-5, 88.97 & 264.14 & 299.09 & Tie to & U1391B-29X-1, 104.77 & 262.85 & 299.09 \\
\hline U1391B-29X-7, 32.34 & 270.37 & 306.61 & Tie to & U1391A-30X-1, 35.12 & 267.35 & 306.61 \\
\hline U1391A-30X-5, 136.53 & 273.70 & 312.96 & Tie to & U1391B-30X-3, 75.54 & 274.12 & 312.96 \\
\hline U1391B-30X-7, 114.69 & 280.44 & 319.28 & Tie to & U1391A-31X-3, 39.91 & 280.01 & 319.28 \\
\hline U1391A-31X-5, 9.21 & 282.09 & 321.36 & Tie to & U1391B-31X-2, 2.2 & 282.52 & 321.36 \\
\hline U1391B-31X-6, 95.61 & 289.47 & 328.31 & Tie to & U1391A-32X-3, 33.84 & 289.03 & 328.31 \\
\hline U1391A-32X-6, 63.22 & 293.63 & 332.91 & Tie to & U1391B-32X-4, 1.91 & 294.08 & 332.91 \\
\hline U1391B-32X-6, 85 & 297.91 & 336.74 & Append to & U1391A-33X-1, 0 & 295.80 & 336.82 \\
\hline U1391A-33X-5, 38.93 & 302.00 & 343.02 & Tie to & U1391B-33X-1, 24 & 300.44 & 343.02 \\
\hline U1391B-33X-4, 119.23 & 305.89 & 348.47 & Tie to & U1391A-34X-1, 36.12 & 305.46 & 348.47 \\
\hline U1391A-34X-6, 103.03 & 313.60 & 356.61 & Tie to & U1391B-34X-2, 64.18 & 311.94 & 356.61 \\
\hline U1391B-34X-6, 108.26 & 318.38 & 363.05 & Tie to & U1391A-35X-3, 86.42 & 318.04 & 363.05 \\
\hline
\end{tabular}


Table T20 (continued).

\begin{tabular}{|c|c|c|c|c|c|c|}
\hline \multirow{2}{*}{$\begin{array}{l}\text { Hole, core, section, } \\
\text { interval }(\mathrm{cm})\end{array}$} & \multicolumn{2}{|c|}{ Depth } & & \multirow{2}{*}{$\begin{array}{l}\text { Hole, core, section, } \\
\text { interval }(\mathrm{cm})\end{array}$} & \multicolumn{2}{|c|}{ Depth } \\
\hline & (mbsf) & $(\mathrm{mcd})$ & & & (mbsf) & (mcd) \\
\hline U1391A-35X-7, 103.87 & 323.60 & 368.61 & Tie to & U1391B-35X-2, 66.24 & 320.34 & 368.61 \\
\hline U1391B-35X-6, 42.33 & 325.83 & 374.10 & Tie to & U1391A-36X-1, 60 & 324.90 & 374.10 \\
\hline U1391A-36X-7, 75.79 & 333.60 & 382.80 & Tie to & U1391B-36X-1, 42.5 & 329.13 & 382.80 \\
\hline U1391B-36X-7, 72.59 & 337.57 & 391.24 & Tie to & U1391A-37X-4, 67.79 & 338.04 & 391.24 \\
\hline U1391A-37X-7, 65.51 & 342.23 & 395.43 & Tie to & U1391B-37X-1, 35.75 & 338.56 & 395.43 \\
\hline U1391B-37X-5, 54.57 & 344.75 & 401.62 & Tie to & U1391A-38X-3, 2.46 & 346.43 & 401.62 \\
\hline U1391A-38X-6, 39.51 & 351.31 & 406.50 & Tie to & U1391C-3R-2, 110.45 & 348.10 & 406.50 \\
\hline U1391C-3R-5, 82.5 & 352.33 & 410.73 & Tie to & U1391B-38X-2, 7.37 & 349.47 & 410.73 \\
\hline U1391B-38X-5, 72.02 & 354.14 & 415.40 & Tie to & U1391C-4R-1, 55 & 355.65 & 415.40 \\
\hline U1391C-4R-2, 130.11 & 357.90 & 417.66 & Append to & U1391C-5R-1, 0 & 364.70 & 425.79 \\
\hline U1391C-5R-7, 71.06 & 374.41 & 435.50 & Append to & U1391C-6R-1, 0 & 374.30 & 436.73 \\
\hline U1391C-6R-2, 137.5 & 377.18 & 439.61 & Append to & U1391C-7R-1, 0 & 383.90 & 447.68 \\
\hline U1391C-7R-5, 137.73 & 391.28 & 455.05 & Append to & U1391C-8R-1, 0 & 393.50 & 458.62 \\
\hline U1391C-8R-5, 68.18 & 399.87 & 464.99 & Append to & U1391C-9R-1, 0 & 403.00 & 469.45 \\
\hline U1391C-9R-6, 152.02 & 412.02 & 478.47 & Append to & U1391C-10R-1, 0 & 412.60 & 480.39 \\
\hline U1391C-10R-5, 89.23 & 419.49 & 487.29 & Append to & U1391C-11R-1, 0 & 422.20 & 491.34 \\
\hline U1391C-11R-6, 132.16 & 431.03 & 500.17 & Append to & U1391C-12R-1, 0 & 431.80 & 502.28 \\
\hline U1391C-12R-7, 69.29 & 441.50 & 511.98 & Append to & U1391C-13R-1, 0 & 441.30 & 513.11 \\
\hline U1391C-13R-7, 71.86 & 451.02 & 522.83 & Append to & U1391C-14R-1, 0 & 450.90 & 524.06 \\
\hline U1391C-14R-7, 71.05 & 460.62 & 533.78 & Append to & U1391C-15R-1, 2.5 & 460.53 & 535.03 \\
\hline U1391C-15R-7, 146.83 & 470.22 & 544.72 & Append to & U1391C-16R-1, 0 & 470.00 & 545.83 \\
\hline U1391C-16R-6, 82.08 & 478.32 & 554.15 & Append to & U1391C-17R-1, 0 & 479.70 & 556.89 \\
\hline U1391C-17R-4, 56.53 & 484.58 & 561.76 & Append to & U1391C-18R-1, 0 & 489.00 & 567.49 \\
\hline U1391C-18R-7, 65 & 498.66 & 577.15 & Append to & U1391C-19R-1, 0.84 & 498.61 & 578.44 \\
\hline U1391C-19R-7, 68.26 & 507.89 & 587.73 & Append to & U1391C-20R-1, 0 & 508.10 & 589.26 \\
\hline U1391C-20R-3, 50.7 & 511.33 & 592.49 & Append to & U1391C-21R-1, 0 & 517.70 & 600.21 \\
\hline U1391C-21R-7, 54.9 & 526.86 & 609.37 & Append to & U1391C-22R-1, 0 & 527.30 & 611.15 \\
\hline U1391C-22R-7, 67.5 & 536.98 & 620.83 & Append to & U1391C-23R-1, 0.03 & 537.00 & 622.21 \\
\hline U1391C-23R-7, 71.66 & 546.74 & 631.95 & Append to & U1391C-24R-1, 0 & 546.60 & 633.15 \\
\hline U1391C-24R-7, 77.34 & 556.38 & 642.94 & Append to & U1391C-25R-1, 0 & 556.20 & 644.10 \\
\hline U1391C-25R-7, 71.64 & 565.92 & 653.81 & Append to & U1391C-27R-1, 0.12 & 575.40 & 665.99 \\
\hline U1391C-27R-6, 117.27 & 584.05 & 674.64 & Append to & U1391C-28R-1, 0 & 585.00 & 676.93 \\
\hline U1391C-28R-7, 66.06 & 594.66 & 686.59 & Append to & U1391C-30R-1, 0 & 604.20 & 698.82 \\
\hline U1391C-30R-7, 73.53 & 613.94 & 708.55 & Append to & U1391C-31R-1, 0 & 613.80 & 709.76 \\
\hline U1391C-31R-7, 73.37 & 623.24 & 719.21 & Append to & U1391C-32R-1, 2.17 & 623.42 & 720.73 \\
\hline U1391C-32R-7, 75.39 & 633.15 & 730.46 & Append to & U1391C-33R-1, 1.61 & 633.02 & 731.67 \\
\hline U1391C-33R-6, 124.7 & 641.76 & 740.41 & Append to & U1391C-34R-1, 0.68 & 642.61 & 742.60 \\
\hline U1391C-34R-7, 89.67 & 652.04 & 752.03 & Append to & U1391C-36R-1, 0 & 661.80 & 764.48 \\
\hline
\end{tabular}


Table T21. Magnetic susceptibility splice, Site U1391.

\begin{tabular}{|c|c|c|c|c|c|}
\hline \multirow{2}{*}{$\begin{array}{l}\text { Core, section, } \\
\text { interval }(\mathrm{cm})\end{array}$} & \multicolumn{2}{|c|}{ Depth } & \multirow[b]{2}{*}{ Offset (m) } & \multirow{2}{*}{$\begin{array}{c}\text { Magnetic } \\
\text { susceptibility }\end{array}$} & \multirow{2}{*}{$\begin{array}{l}\text { Magnetic } \\
\text { susceptibility } \\
\text { cleaned }\end{array}$} \\
\hline & (mbsf) & $(\mathrm{mcd})$ & & & \\
\hline \multicolumn{6}{|l|}{ 339-U1391A- } \\
\hline $1 \mathrm{H}-1,0$ & 0.000 & 0.00 & 0.00 & 23.00 & \\
\hline $1 \mathrm{H}-1,2.5$ & 0.025 & 0.03 & 0.00 & 39.67 & 39.67 \\
\hline $1 \mathrm{H}-1,5$ & 0.050 & 0.05 & 0.00 & 42.67 & 42.67 \\
\hline $1 \mathrm{H}-1,7.5$ & 0.075 & 0.08 & 0.00 & 44.00 & 44.00 \\
\hline $1 \mathrm{H}-1,10$ & 0.100 & 0.10 & 0.00 & 44.00 & 44.00 \\
\hline $1 \mathrm{H}-1,12.5$ & 0.125 & 0.13 & 0.00 & 43.67 & 43.67 \\
\hline $1 \mathrm{H}-1,15$ & 0.150 & 0.15 & 0.00 & 43.67 & 43.67 \\
\hline $1 \mathrm{H}-1,17.5$ & 0.175 & 0.18 & 0.00 & 43.00 & 43.00 \\
\hline $1 \mathrm{H}-1,20$ & 0.200 & 0.20 & 0.00 & 43.33 & 43.33 \\
\hline $1 \mathrm{H}-1,22.5$ & 0.225 & 0.23 & 0.00 & 44.33 & 44.33 \\
\hline $1 \mathrm{H}-1,25$ & 0.250 & 0.25 & 0.00 & 43.33 & 43.33 \\
\hline $1 \mathrm{H}-1,27.5$ & 0.275 & 0.28 & 0.00 & 42.00 & 42.00 \\
\hline $1 \mathrm{H}-1,30$ & 0.300 & 0.30 & 0.00 & 42.33 & 42.33 \\
\hline $1 \mathrm{H}-1,32.5$ & 0.325 & 0.33 & 0.00 & 43.00 & 43.00 \\
\hline $1 \mathrm{H}-1,35$ & 0.350 & 0.35 & 0.00 & 40.67 & 40.67 \\
\hline $1 \mathrm{H}-1,37.5$ & 0.375 & 0.38 & 0.00 & 38.00 & 38.00 \\
\hline $1 \mathrm{H}-1,40$ & 0.400 & 0.40 & 0.00 & 37.00 & 37.00 \\
\hline $1 \mathrm{H}-1,42.5$ & 0.425 & 0.43 & 0.00 & 36.67 & 36.67 \\
\hline $1 \mathrm{H}-1,45$ & 0.450 & 0.45 & 0.00 & 37.00 & 37.00 \\
\hline $1 \mathrm{H}-1,47.5$ & 0.475 & 0.48 & 0.00 & 38.00 & 38.00 \\
\hline $1 \mathrm{H}-1,50$ & 0.500 & 0.50 & 0.00 & 39.00 & 39.00 \\
\hline $1 \mathrm{H}-1,52.5$ & 0.525 & 0.53 & 0.00 & 40.33 & 40.33 \\
\hline $1 \mathrm{H}-1,55$ & 0.550 & 0.55 & 0.00 & 41.33 & 41.33 \\
\hline $1 \mathrm{H}-1,57.5$ & 0.575 & 0.58 & 0.00 & 41.00 & 41.00 \\
\hline $1 \mathrm{H}-1,60$ & 0.600 & 0.60 & 0.00 & 41.33 & 41.33 \\
\hline $1 \mathrm{H}-1,62.5$ & 0.625 & 0.63 & 0.00 & 41.00 & 41.00 \\
\hline $1 \mathrm{H}-1,65$ & 0.650 & 0.65 & 0.00 & 41.00 & 41.00 \\
\hline $1 \mathrm{H}-1,67.5$ & 0.675 & 0.68 & 0.00 & 26.00 & 26.00 \\
\hline $1 \mathrm{H}-1,70$ & 0.700 & 0.70 & 0.00 & 39.00 & 39.00 \\
\hline $1 \mathrm{H}-1,72.5$ & 0.725 & 0.73 & 0.00 & 40.00 & 40.00 \\
\hline $1 \mathrm{H}-1,75$ & 0.750 & 0.75 & 0.00 & 40.00 & 40.00 \\
\hline $1 \mathrm{H}-1,77.5$ & 0.775 & 0.78 & 0.00 & 40.00 & 40.00 \\
\hline $1 \mathrm{H}-1,80$ & 0.800 & 0.80 & 0.00 & 39.33 & 39.33 \\
\hline $1 \mathrm{H}-1,82.5$ & 0.825 & 0.83 & 0.00 & 39.67 & 39.67 \\
\hline $1 \mathrm{H}-1,85$ & 0.850 & 0.85 & 0.00 & 39.00 & 39.00 \\
\hline $1 \mathrm{H}-1,87.5$ & 0.875 & 0.88 & 0.00 & 39.33 & 39.33 \\
\hline $1 \mathrm{H}-1,90$ & 0.900 & 0.90 & 0.00 & 40.00 & 40.00 \\
\hline $1 \mathrm{H}-1,92.5$ & 0.925 & 0.93 & 0.00 & 40.00 & 40.00 \\
\hline $1 \mathrm{H}-1,95$ & 0.950 & 0.95 & 0.00 & 41.33 & 41.33 \\
\hline $1 \mathrm{H}-1,97.5$ & 0.975 & 0.98 & 0.00 & 42.00 & 42.00 \\
\hline $1 \mathrm{H}-1,100$ & 1.000 & 1.00 & 0.00 & 42.00 & 42.00 \\
\hline $1 \mathrm{H}-1,102.5$ & 1.025 & 1.03 & 0.00 & 42.00 & 42.00 \\
\hline $1 \mathrm{H}-1,105$ & 1.050 & 1.05 & 0.00 & 41.33 & 41.33 \\
\hline $1 \mathrm{H}-1,107.5$ & 1.075 & 1.08 & 0.00 & 40.00 & 40.00 \\
\hline $1 \mathrm{H}-1,110$ & 1.100 & 1.10 & 0.00 & 34.33 & 34.33 \\
\hline $1 \mathrm{H}-1,112.5$ & 1.125 & 1.13 & 0.00 & 17.33 & 17.33 \\
\hline $1 \mathrm{H}-1,115$ & 1.150 & 1.15 & 0.00 & 18.00 & 18.00 \\
\hline $1 \mathrm{H}-1,117.5$ & 1.175 & 1.18 & 0.00 & 33.33 & 33.33 \\
\hline $1 \mathrm{H}-1,120$ & 1.200 & 1.20 & 0.00 & 38.00 & 38.00 \\
\hline $1 \mathrm{H}-1,122.5$ & 1.225 & 1.23 & 0.00 & 38.00 & 38.00 \\
\hline $1 \mathrm{H}-1,125$ & 1.250 & 1.25 & 0.00 & 38.00 & 38.00 \\
\hline $1 \mathrm{H}-1,127.5$ & 1.275 & 1.28 & 0.00 & 38.33 & 38.33 \\
\hline $1 \mathrm{H}-1,130$ & 1.300 & 1.30 & 0.00 & 39.00 & 39.00 \\
\hline $1 \mathrm{H}-1,132.5$ & 1.325 & 1.33 & 0.00 & 39.67 & 39.67 \\
\hline $1 \mathrm{H}-1,135$ & 1.350 & 1.35 & 0.00 & 39.00 & 39.00 \\
\hline $1 \mathrm{H}-1,137.5$ & 1.375 & 1.38 & 0.00 & 38.00 & 38.00 \\
\hline $1 \mathrm{H}-1,140$ & 1.400 & 1.40 & 0.00 & 37.00 & 37.00 \\
\hline $1 \mathrm{H}-1,142.5$ & 1.425 & 1.43 & 0.00 & 36.33 & 36.33 \\
\hline $1 \mathrm{H}-1,145$ & 1.450 & 1.45 & 0.00 & 35.00 & 35.00 \\
\hline $1 \mathrm{H}-1,147.5$ & 1.475 & 1.48 & 0.00 & 32.00 & 32.00 \\
\hline
\end{tabular}

Only a portion of this table appears here. The complete table is available in ASCII. 
Table T22. Natural gamma radiation (NGR) splice, Site U1391.

\begin{tabular}{|c|c|c|c|c|c|c|}
\hline \multirow{2}{*}{$\begin{array}{l}\text { Hole, core, section, } \\
\text { interval }(\mathrm{cm})\end{array}$} & \multicolumn{2}{|c|}{ Depth } & \multirow[b]{2}{*}{ Offset (m) } & \multirow[b]{2}{*}{ NGR (cps) } & \multicolumn{2}{|c|}{ Error } \\
\hline & (mbsf) & $(\mathrm{mcd})$ & & & (cps) & (\%) \\
\hline \multicolumn{7}{|l|}{$339-$} \\
\hline U1391A-1H-1 & 0.00 & 0.00 & 0.00 & 21.9279 & 1.3211 & 0.0602 \\
\hline U1391A-1H-1, 10 & 0.10 & 0.10 & 0.00 & 20.4376 & 0.4421 & 0.0216 \\
\hline U1391A-1H-1, 20 & 0.20 & 0.20 & 0.00 & 22.6205 & 0.2521 & 0.0111 \\
\hline U1391A-1H-1, 30 & 0.30 & 0.30 & 0.00 & 23.6014 & 0.2567 & 0.0109 \\
\hline U1391A-1H-1, 40 & 0.40 & 0.40 & 0.00 & 23.3433 & 0.2627 & 0.0113 \\
\hline U1391A-1H-1, 50 & 0.50 & 0.50 & 0.00 & 23.6123 & 0.2639 & 0.0112 \\
\hline U1391A-1H-1, 60 & 0.60 & 0.60 & 0.00 & 25.2522 & 0.2704 & 0.0107 \\
\hline U1391A-1H-1, 70 & 0.70 & 0.70 & 0.00 & 26.2261 & 0.2746 & 0.0105 \\
\hline U1391A-1H-1, 80 & 0.80 & 0.80 & 0.00 & 26.6025 & 0.2763 & 0.0104 \\
\hline U1391A-1H-1, 90 & 0.90 & 0.90 & 0.00 & 26.7382 & 0.2769 & 0.0104 \\
\hline U1391A-1H-1, 100 & 1.00 & 1.00 & 0.00 & 26.6892 & 0.2760 & 0.0103 \\
\hline U1391A-1H-1, 110 & 1.10 & 1.10 & 0.00 & 22.8773 & 0.2590 & 0.0113 \\
\hline U1391A-1H-1, 120 & 1.20 & 1.20 & 0.00 & 23.8130 & 0.2556 & 0.0107 \\
\hline U1391A-1H-1, 130 & 1.30 & 1.30 & 0.00 & 26.7202 & 0.2688 & 0.0101 \\
\hline U1391A-1H-1, 140 & 1.40 & 1.40 & 0.00 & 26.7158 & 0.5481 & 0.0205 \\
\hline U1391A-1H-1, 150 & 1.50 & 1.50 & 0.00 & 24.8659 & 1.4868 & 0.0598 \\
\hline U1391A-1H-2, 10 & 1.60 & 1.60 & 0.00 & 28.0064 & 0.5698 & 0.0203 \\
\hline U1391A-1H-2, 30 & 1.80 & 1.80 & 0.00 & 29.0586 & 0.2807 & 0.0097 \\
\hline U1391A-1H-2, 50 & 2.00 & 2.00 & 0.00 & 29.4290 & 0.2890 & 0.0098 \\
\hline U1391B-1H-1, 130 & 1.30 & 2.09 & 0.79 & 28.7626 & 0.2777 & 0.0097 \\
\hline U1391B-1H-1, 150 & 1.50 & 2.29 & 0.79 & 27.3568 & 1.5426 & 0.0564 \\
\hline U1391B-1H-2, 10 & 1.61 & 2.40 & 0.79 & 32.8975 & 0.6529 & 0.0198 \\
\hline U1391B-1H-2, 30 & 1.81 & 2.60 & 0.79 & 34.1276 & 0.3014 & 0.0088 \\
\hline U1391B-1H-2, 50 & 2.01 & 2.80 & 0.79 & 36.3695 & 0.3163 & 0.0087 \\
\hline U1391B-1H-2, 70 & 2.21 & 3.00 & 0.79 & 37.8855 & 0.3210 & 0.0085 \\
\hline U1391B-1H-2, 90 & 2.41 & 3.20 & 0.79 & 36.1596 & 0.3147 & 0.0087 \\
\hline U1391B-1H-2, 110 & 2.61 & 3.40 & 0.79 & 36.5849 & 0.3157 & 0.0086 \\
\hline U1391B-1H-2, 130 & 2.81 & 3.60 & 0.79 & 33.8333 & 0.4424 & 0.0131 \\
\hline U1391B-1H-3, 10 & 3.11 & 3.90 & 0.79 & 37.0477 & 0.7235 & 0.0195 \\
\hline U1391B-1H-3, 30 & 3.31 & 4.10 & 0.79 & 37.9776 & 0.3163 & 0.0083 \\
\hline U1391B-1H-3, 50 & 3.51 & 4.30 & 0.79 & 37.9242 & 0.3221 & 0.0085 \\
\hline U1391B-1H-3, 70 & 3.71 & 4.50 & 0.79 & 38.0545 & 0.3217 & 0.0085 \\
\hline U1391B-1H-3, 90 & 3.91 & 4.70 & 0.79 & 39.1477 & 0.3258 & 0.0083 \\
\hline U1391B-1H-3, 110 & 4.11 & 4.90 & 0.79 & 39.3182 & 0.3258 & 0.0083 \\
\hline U1391B-1H-3, 130 & 4.31 & 5.10 & 0.79 & 35.9221 & 0.3068 & 0.0085 \\
\hline U1391B-1H-3, 150 & 4.51 & 5.30 & 0.79 & 34.8122 & 2.0500 & 0.0589 \\
\hline U1391B-1H-4, 10 & 4.61 & 5.40 & 0.79 & 38.3587 & 0.7459 & 0.0194 \\
\hline U1391B-1H-4, 30 & 4.81 & 5.60 & 0.79 & 40.5491 & 0.3258 & 0.0080 \\
\hline U1391B-1H-4, 50 & 5.01 & 5.80 & 0.79 & 41.8718 & 0.3364 & 0.0080 \\
\hline U1391A-2H-1, 90 & 5.00 & 5.95 & 0.95 & 37.0430 & 0.3180 & 0.0086 \\
\hline U1391A-2H-1, 110 & 5.20 & 6.15 & 0.95 & 37.0778 & 0.3175 & 0.0086 \\
\hline U1391A-2H-1, 130 & 5.40 & 6.35 & 0.95 & 34.3483 & 0.3007 & 0.0088 \\
\hline U1391A-2H-1, 150 & 5.60 & 6.55 & 0.95 & 23.3724 & 1.4025 & 0.0600 \\
\hline U1391A-2H-2, 10 & 5.70 & 6.65 & 0.95 & 39.5747 & 0.7667 & 0.0194 \\
\hline U1391A-2H-2, 30 & 5.90 & 6.85 & 0.95 & 40.1657 & 0.3244 & 0.0081 \\
\hline U1391A-2H-2, 50 & 6.10 & 7.05 & 0.95 & 39.6623 & 0.3285 & 0.0083 \\
\hline U1391A-2H-2, 70 & 6.30 & 7.25 & 0.95 & 36.9307 & 0.3175 & 0.0086 \\
\hline U1391A-2H-2, 90 & 6.50 & 7.45 & 0.95 & 38.0644 & 0.3218 & 0.0085 \\
\hline U1391A-2H-2, 110 & 6.70 & 7.65 & 0.95 & 40.0730 & 0.3286 & 0.0082 \\
\hline U1391A-2H-2, 130 & 6.90 & 7.85 & 0.95 & 36.8174 & 0.3103 & 0.0084 \\
\hline U1391A-2H-2, 150 & 7.10 & 8.05 & 0.95 & 34.7811 & 2.0483 & 0.0589 \\
\hline U1391A-2H-3, 10 & 7.20 & 8.15 & 0.95 & 40.7662 & 0.7870 & 0.0193 \\
\hline U1391A-2H-3, 30 & 7.40 & 8.35 & 0.95 & 40.6276 & 0.3261 & 0.0080 \\
\hline U1391A-2H-3, 50 & 7.60 & 8.55 & 0.95 & 41.5980 & 0.3354 & 0.0081 \\
\hline U1391A-2H-3, 70 & 7.80 & 8.75 & 0.95 & 41.2260 & 0.3332 & 0.0081 \\
\hline U1391A-2H-3, 90 & 8.00 & 8.95 & 0.95 & 38.4049 & 0.3231 & 0.0084 \\
\hline U1391A-2H-3, 110 & 8.20 & 9.15 & 0.95 & 38.8278 & 0.3240 & 0.0083 \\
\hline U1391A-2H-3, 130 & 8.40 & 9.35 & 0.95 & 36.2078 & 0.3079 & 0.0085 \\
\hline U1391A-2H-4, 10 & 8.70 & 9.65 & 0.95 & 38.3261 & 0.7454 & 0.0194 \\
\hline
\end{tabular}

Only a portion of this table appears here. The complete table is available in ASCII. 